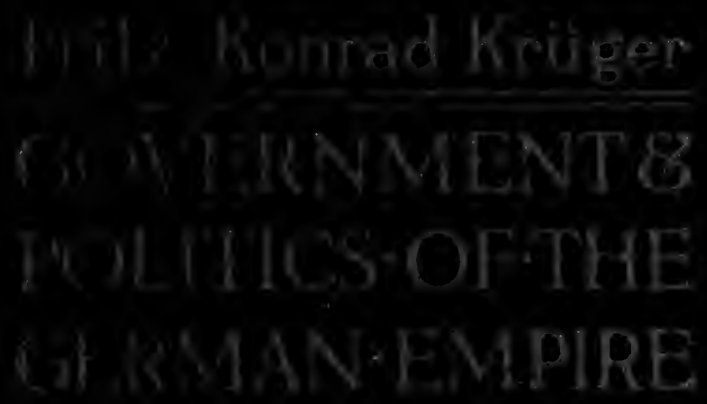




\section{LIBRARY

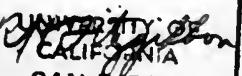 SAN BPEGO}


Digitized by the Internet Archive in 2007 with funding from Microsoft Corporation 
Government and Politics of the German Empire 
Government Handbooks is a new series of college textbooks in government prepared under the joint editorship of David Prescott Barrows, Ph.D., Professor of Political Science and Dean of the Faculties in the University of California, and Thomas Harrison Reed, A.B., LL.B., Assistant Professor of Government in the University of California.

The Series will provide a handbook for each of the European countries, and one on the Government of American Dependencies, treating of the political and administrative organization. Each volume will have such maps and illustrations as are needed, and will contain an annotated bibliography.

The authors of the different volumes are men who combine a thorough knowledge of the subject and a personal acquaintance with the country and system described.

One volume is now published, Government and Politics of the German Empire, by Fritz-Konrad Krüger, Ph.D., of the Department of Political Science, University of California. Others are in preparation, to be issued during 1916. Some of the volumes already planned are: Government of American Dependencies, by Dr. David Prescott Barrows; Government and Politics of Great Britain, by Thomas Harrison Reed; The Government of The Swiss Confederation, by Bernard D. Moses, Ph.D., LL.D., Professor of History and Political Science, University of California; Government and Administration of Prussia and the Federal States of the German Empire, by Herman G. James, Ph.D., J.D., Adjunct Professor of Government, University of Texas.

The publishers cordially invite correspondence with regard to the Series. 


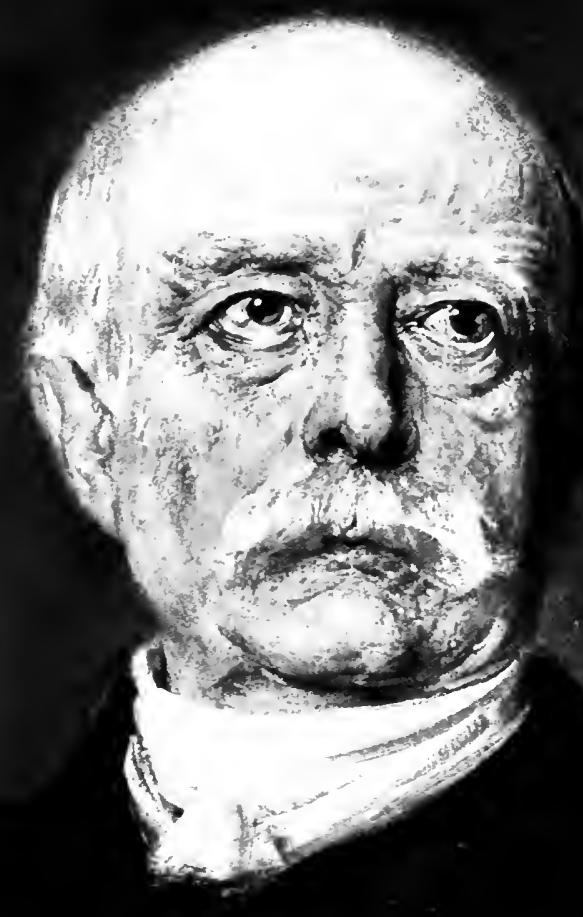

PRINCE BISIIARCK

First Chancellor of the German Empire 
Edited by David P. Barrows and Thomas H. ReED Bobernment anobola

\title{
Government and Politics \\ of the
}

\section{German Empire}

\author{
BY \\ FRITZ-KONRAD KRÜGER \\ DOKTOR DER STAATSWISSENSCHAFTEN \\ (Tübingen), м.A. (Nebraska)
}

\section{YONKERS-ON-HUDSON : : : NEW YORK}

WORLD BOOK COMPANY

I9I 5 
COPYRIGHT, I 9 I 5

BY WORLD BOOK COMPANY

COPYRIGHT IN ENGIAND

ALI RIGHTS RESERVED 


\section{INTRODUCTION TO THE SERIES}

WHE Handbooks of Modern Government, of which Dr. Krïger's Government and Politics of the German Empire is the first, are planned for the double purpose of supplying college classes in government with handy, authoritative texts and of furnishing the public with convenient volumes for reading and reference. The plan is to cover the important governments not only of Europe but of other parts of the world and certain colonial dependencies. Each volume will be written by a specialist in the history and institutions of the country concerned, and from first hand knowledge of actual conditions. The announcement of certain volumes already in preparation is made on another page.

The attention of the American people has been too exclusively fixed upon their own government and its problems. Guidance is assuredly to be found in the political efforts of other enlightened peoples, and past ignorance of the national aspirations of the rest of the world is no longer tolerable. These books are written especially for the service they may render to the American student and public, and in the absence of comparable works in the 


\section{INTRODUCTION}

English language it is hoped they may be found welcome.

It is not the intention of the editors to limit authors in their expression of opinion, providing views are expressed with courtesy and moderation. Necessarily, and we believe preferably, the fixed conviction of the authors as regards the practice of government and political policies will be reflected in their pages. The present volume is a good example of what the editors hope for in the way of judicious and patriotic expression. The author is in general in sympathy with the principles of the National Liberal party of Germany, and it is believed his views reflect the common opinion of the great body of the German nation at the present time. Without attempting in any sense to be a defense of either German government or politics it is a conservative and restrained judgment of German achievement and expectations. There are special reasons at the present time why a book conceived in this spirit should have a place in the formation of American public opinion.

\section{The EDITOR}

\section{University of California}




\section{PREFACE}

$7 \mathrm{HE}$ author wishes to emphasize that his 1 book has purely an educational purpose. It is the result of several years of study and teaching. The outbreak of the European war has in no way affected the contents of the book or the opinions expressed therein. Neither has the so-called war literature found a place in the bibliography, since most of it has been written with a certain bias and often with the most malicious misinterpretation of facts. It is sensational and will disappear after the war. The author hopes that this book, besides serving as a textbook for college students, will help serious and fair minded people in forming their opinion of German government and politics.

The writer wishes to express his gratitude to the editors of this series of government handbooks, Professor D. P. Barrows and Professor T. H. Reed, of the University of California, for constant assistance and encouragement throughout the preparation of this volume, including the reading of the proofs. The author is also highly indebted to Professor M. Bonn of the University of Munich for many valuable suggestions. His thanks furthermore are due to Komerzienrat J. H. Zimmermann, member of the Reichstag, for some 


\section{PREFACE}

information in regard to that body. Finally the author desires to acknowledge the assistance he has received from the following students of his seminar in the University of California: Mr. W. Aschenbrenner, J. D.; Mr. A. Lagerstedt, M. A.; Mr. C. E. Martin; and Mr. H. Stern.

FrITZ-KonRad KRÜGER

Berkeley, California 


\section{CONTENTS}

CHAPTER

PAGE

I. The Physical Basis of the German Empire I

II. The foundation of the German Empire. 13

1II. The Development of the Constitution . 24

IV. The Nature of the German Empire. . . 33

V. The Reichstag . . . . . . . . 45

VI. The Bundesrat . . . . . . . . . 64

VII. The Kaiser . . . . . . . . . . . 74

VIII. The Chancellor and His Substitutes . . 97

IX. The Law-Making Process ...... . IIo

X. The Administration of the Interior . I I 7

XI. The Finances of the German Empire . I 134

XII. The ARMY ......... . . . . . 149

XIII. The Navy of The EMpire . . . . . . . I60

XIV. Railroads, Canals, Posts and Telegraphs 167

XV. The Government of Alsace-Lorraine . . 176

XVI. The Judicial System of the German Empire 183

XVII. The Parliamentary History of Germany 205

XVIII. Germany's Foreign Policy since 1871 • 235

XIX. The Colonial Dependencies . . . . 260

APPENDIX . . . . . . . . . . . . 275

Critical Bibliography. . . . . . . . . 277

Outline of the Government of the States of

the German Empire . . . . . . . . . . 3 II

INDEX . . . . . . . . . . . . 317 



\section{LIST OF ILLUSTRATIONS}

Prince Bismarck . . . . . . . . . Frontispiece

The Composition of the German Reichstag . Facing page 48 Seating Plan of the Reichstag . . . . . . 52 William I. . . . . . . . . . . 80

Frederick III . . . . . . . . . . . 86

William II . . . . . . . . . . . . . . . . 94

Count Caprivi . . . . . . . . . . . . 102

Prince Hohenlohe-Schillingsfürst . . . . . . 104 Prince Bülow . . . . . . . . . . 106

D. von Bethmann-Hollweg ........ 108 



\section{Government and Politics of the German Empire}

\section{CHAPTER I}

THE PHYSICAL BASIS OF THE GE RMA N EMPIRE

$7 \mathrm{HE}$ German Empire lies between the $55^{\text {th }}$ and the 48 th degrees of north lati-

1 tude. It therefore is a country of me-

Territory and climate

dium temperature. It is somewhat colder than its latitude would indicate, since it is closed by the Alps against the mild winds of the South and open to the cold northern and eastern regions of Europe. The Atlantic Ocean makes the weather of the Northwest milder, while the general altitude and the Alp wall make the South colder, with the result that the average yearly temperature as a whole is higher in northern Germany. The four seasons are distinctly different from each other, thus giving the people a refreshing and very desirable change. Germany as a whole is a damp country. All seasons bring humidity, especially the spring and the late summer, the southern mountainous territory receiving a heavier precipitation than the northern plain. 


\section{GERMAN GOVERNMENT AND POLITICS}

On the other hand the North has steadier winds than the South, which come from the southwest and west. As a whole, it may be said that the climate of Germany is refreshing rather than mild. It does not enervate the inhabitants as the climate of southern Europe; it sets them to work. At the same time, Germany is protected from that grave cold of more northern countries which kills the joy of life.

The German Empire has more and stronger neighbors than any other state. Russia, AustriaHungary and France are the most important, but in addition to these it has on its borders the territories of Holland, Belgium, Denmark, Switzerland and Luxemburg. Naturally, Germany has often been influenced by foreign elements, and she has often in the past been the chosen ground for European wars.

German's central

The central location of Germany in Europe European has made her people more cosmopolitan than location

others. It has made Germany the classical country of translation and the birthplace of the idea of a world-literature. It has also caused her people often to overestimate the value of foreign products. Her position makes absolutely necessary the maintenance of a strong army and alliances with other states. Ratzel, in his excellent study on the political geography of Germany, says of her situation in Europe: "The central location of Germany and her mass of neighbors may be her weakness as well as her [2] 
strength. Germany exists only if she is strong; a weak state would succumb to the concentric pressure. And Germany can profit by her central location only if she is strong. For a state in Germany's position there exist only the possibilities of combining all her strength and maintaining her place in the world by incessant labor, of being pressed to pieces like Poland, or of placing herself under the protection of neutrality like Switzerland."

The area of the German Empire ${ }^{1}$ is very small Area compared with that of other leading countries. It is not more than 208,780 square miles, while Texas alone has 265,896 square miles. The United States, as a whole, is seventeen times larger, the British Empire about forty-seven, Russia fortyone times. As a European power, Germany takes the third place as to size. As a colonial power, also Germany now has the third place as to territory. Her colonial territory is about five times as large as that of the mother country. Of the German territory in Europe, Prussia has 65 per cent, Bavaria 14 per cent, Saxony 2.8 per cent, the other four states of South Germany, Würtemberg, Baden, Hesse, Alsace-Lorraine, ro per cent.

Politically, the territory is divided naturally into three parts: the northern part, in which

Prussia dominates and which is the most conservative and aristocratic; the southern part, in which Bavaria is the strongest state and where

1 Compare p. 275. 


\section{GERMAN GOVERNMENT AND POLITICS}

the general spirit is much more democratic; and Central Germany with its mass of small duchies and principalities, which form a bridge from the North to the South. Popula- The total population of the German Empire

was about sixty-seven millions in 1913. Of the $63,666,120$ German citizens living in Germany in the year 1910, about $3,087,000$ were Poles, 212,000 French, 93,000 Wends, I41,000 Danes. Nineteen thousand and fifty German citizens live in the "protectorates." Out of the 64,925,993 people living in Germany, in rgro there were r, 259,873 foreign subjects.

The western part of Germany is more densely populated than the eastern part, the greatest density being in Saxony and the Rhine Province. Of the whole German population Prussia has about eight thirteenths. More and more the farming population migrates to the cities, which have grown rapidly within the last twenty years. In 1895 there were only twenty-eight cities with more than 100,000 inhabitants, now there are forty-eight. ${ }^{1}$ The percentage of the urban population in 1822 was 27 per cent of the whole population, in $1905,54.3$ per cent.

The largest part of the population, i.e., 62.I per cent, is Protestant; Catholics are found especially in South Germany, including Alsace-Lorraine, in the Prussian Rhine-Province and among

1 The United States has 51 cities of more than 100,000 inhabitants, and Great Britain $4 \mathrm{I}$.

[4] 
the Poles. In the whole German Empire there are 36.5 per cent Catholics.

The question of German citizenship was settled by the law of June I, $1879 . .^{1}$ According to this law, Citizenship which is based on the general principles of Article 3 of the Constitution, every citizen of a German state is a citizen of the Empire. Citizenship of the German Empire is usually determined by citizenship in one of the individual states. It is possible, however, to be a citizen of the Union alone, i.e., in the protectorates or by accepting a position as an Imperial officer. A citizen of one of the German states may also be a citizen of any other state, a situation which causes no complications. German citizenship may be acquired by:

I. Birth: Germany recognizes the jus sanguinis, i.e., the citizenship of the parents decides that of the child. In case of illegitimate birth, the child takes the mother's citizenship.

2. Legitimation: An illegitimate child recognized by a German father becomes a citizen. The same rule does not apply to adopted children.

3. Marriage: A foreign woman, marrying a citizen, takes the citizenship of her husband. In case the marriage is invalid the woman loses the citizenship, but not in case of divorce.

4. Office holding: Appointment to a civil service position under the Empire, or in one of the

1 "Gesetz über Erwerb und Verlust der Staatsangehörigkeit"; changed by law of July 22, 1913 under the name "Reichs und Staatsangehörigkeitzgesetz." 


\section{GERMAN GOVERNMENT AND POLITICS}

states or cities, or in one of the state churches makes the person a German citizen. These officers are ipso jure citizens if they reside in German territory; if they reside abroad and receive a salary, they have to be accepted as citizens by the state making the appointment. ${ }^{1}$

5. Naturalization: This is not, as in the United States, a judicial act; it is left to the discretion of certain higher administrative officers as, for example, in Prussia to the Regierungspräsident. Except for a few fundamental principles, the whole matter, in strict contrast to the practice of the United States, is left to the states. The Imperial law prescribes that the applicant must (I) be of legal age according to the law of the country of whose allegiance he seeks to divest himself; (2) have good moral character; (3) have his residence in the place where he desires to be naturalized; (4) be capable of supporting himself and his family. The state may add any other regulation not opposed to the general spirit of this law or the Constitution. A person who has fulfilled all the requirements of the law is not by that fact entitled to naturalization, he may still be refused. ${ }^{2}$ Naturalization affects all minor children

1 Law of December 20, 1875.

2 A German, however, who has lost his citizenship when he was a minor, has now (since 1913) a legal right to naturalization if he asks for it within two years after he attains his majority. Likewise, former German citizens and their children are entitled to naturalization in the state to which they formerly belonged.

[6] 


\section{PHYSICAL BASIS OF THE EMPIRE}

except married daughters. Minor children may, however, be excluded by a special order of the administrative authorities.

Entirely different from naturalization is the socalled "reception," Aufnahme, i.e., the taking over of a citizen by one state from another state within the Empire. This privilege has to be granted to every citizen who asks for it except in the case of criminals and of persons in receipt of poor relief.

German citizenship may be lost by:

I. Legitimation of an illegitimate child by a foreign father.

2. Marriage of a German woman to a foreigner.

3. Dismissal: It is always granted with limitations in regard to the obligations of military service. Men in active service may not be dismissed; men between the ages of seventeen and twenty-five years only if they promise to return in order to take up their military service; officers, recruits and volunteers, who have been accepted, can be dismissed only with the consent of the military magistracy.

4. Deprivation: If a citizen does not follow the call of the Kaiser in case of war, or if he accepts an official position in a foreign state without the consent of his home state, and does not give it up, when required to do so, or if he escapes military service, he may be deprived of his citizenship.

The Constitution of the German Empire does and duties not contain any "bill of rights," although that ${ }_{\operatorname{man}}$ of Prussia does. The rights belonging to citizens cittzens 


\section{GERMAN GOVERNMENT AND POLITICS}

of the Empire may be found scattered through numerous laws. The fundamental right of every citizen is that of protection by the state. No citizen can be expelled or extradited to a foreign power. ${ }^{1}$ Based upon this principle is the right of every German citizen except criminals and those in receipt of poor relief ${ }^{2}$ to live and have his residence in any part of the Empire. Furthermore every citizen has the privilege of protection in foreign countries. In any case where injustice is done to a German citizen abroad, the German diplomatic and consular officers are obliged to seek satisfaction for the injured party, and finally a citizen has the right to participate in the government of Germany in accordance with the terms of the Constitution.

Every citizen has two classes of duties, those of obedience and those of fidelity. The citizen owes implicit obedience to the government. This, however, does not exclude the right to protest. A citizen has always through the administrative courts the opportunity of getting satisfaction for a violation of his rights by any organ of the state. Another important duty of a German citizen - at the same time a privilege - is that of serving in the army. The duty of fidelity means the abstention from any act detrimental to the state. Such acts are, (I) Treason, includ-

1 Criminal Law Code $\S 9$

2 R. G. of November I, 1867. [R. G. = Reichsgesetz or Imperial Law.]

[8] 
ing crimen laesae majestatis against the Kaiser or the ruler of one's own state; (2) hostile acts against other states of the Union or insults to their princes; (3) hostile acts against allied states or insults to their rulers.

In considering those traits of racial character which especially have influenced the political institutions of Germany, we must first mention the strong individualism of the Germans. Caesar and Tacitus spoke of it as a significant side of the Germanic character. The old Germans were scattered over the country. They hated the conglomeration of people in cities because they were Influence of racial character upon political institutions

Individualism afraid it might diminish their individual liberty. Their political institutions were based upon temporary voluntary agreements. They did not recognize kings. Their dukes were elected only for limited periods. This love of personal freedom played a great part in the progress of the reorganization of Germany and for centuries prevented a real unification of Germany, and it is still manifest in some parts of the Empire. It explains that great local pride which stimulates city governments to useful competition and that detrimental antagonism which set tribe against tribe and territory against territory up to the foundation of the German Empire. This characteristic feature of the German people is fundamentally the reason why Germany is a federation and not a unitary state. In connection with a love for abstract thinking, this individualistic spirit 


\section{GERMAN GOVERNMENT AND POLITICS}

is the cause of the numerous parties which complicate German politics. There is a well-known saying that wherever two Germans are together, there are three different opinions. They do not easily compromise, and in foreign countries they do not work together. Therefore they soon lose their national identity and have very little influence upon the politics of their adopted country. National feeling, however, is steadily growing and it is to be expected that soon pride in belonging to a strong and powerful nation will overcome this super-individualistic spirit. On the other hand the Germans are remarkable for their ability to coöperate and organize.

Love of familly

Another characteristic feature of the German is his great love for what is in reality the foundation of every commonwealth - the family. The family is sacred to the German and an insult to any member of it is resented by even its most distant connections. The wife is still regarded as the cornerstone of the family and no woman is more honored in Germany than a good wife and a good mother. Again and again a regeneration of the country has originated in the family, the source of Germanic strength.

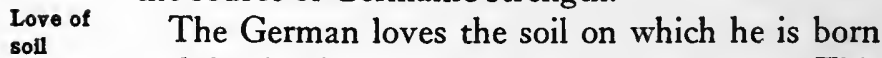
and he is therefore the best of farmers. This characteristic is evidenced in the Middle West of the United States, where German-Americans own much of the farm lands and show the least desire to follow the general trend to the cities. [10] 
PHYSICAL BASIS OF THE EMPIRE

Unfortunately, this devotion to the soil is often accompanied by a too pronounced conservatism, which hinders progress.

As a whole, it can be said that the German mind works slowly and is not easily excited, but once aroused, one has to count with..that furor Slowness and thoroughTeutonicus of which the old Romans spoke with great fear. If the German recognizes a certain political course as good he carries it into effect with consistency and thoroughness as, for example, his great social reforms, the building of a navy and the making of the great codes of law.

A peculiarly Prussian virtue, which has helped to make this state the leading one of Germany, is Sense of respons1bllity

a widespread sense of responsibility. "Duty" Kant's conception of it - doing any work to be done without first looking for compensation, without regard to personal well being-even against the strongest opposition and until death - that is the cold but great Prussian word. And in this respect the rulers of the House of Hohenzollern, with very few exceptions, have been brilliant examples for every officer and subject of the state.

In no nation perhaps are the military virtues as highly developed as in Germany. The fighting spirit of the old Teutons has been handed down from generation to generation. Unfortunately, it has too often been wasted in civil wars or lent to foreign nations. The situation of Germany in 


\section{GERMAN GOVERNMENT AND POLITICS}

Europe has kept the people always under arms and to this day Germany is the last country which can permit herself to play with romantic ideas of universal peace. It is the true German spirit, which the present Crown Prince of Germany, Frederic William, gives us in his book "Deutschland in Waffen," where he says: "Joy in bearing arms was ever in the hearts of our people. Even with the old Teutons a youth became a man only after he had his baptism of fire. . . . This warlike, loyal and proud spirit we must cherish and transmit as a holy heritage to our children. . . . The German who loves his people, who believes in the greatness and the future of our homeland, dares not let himself be soothed to slumber with the utopian songs of peace. ... And therefore every man who loves his country and believes in the great future of his people must joyfully contribute his part to prevent the old soldier spirit of our fathers from being lost."

\section{SELECTED BIBLIOGRAPHY}

Howard, B. E. "The German Empire," Chapter VIII (Citizenship under the German Constitution).

Burgess, J. W. "Political Science and Comparative Constitutional Law," Vol. I, Book II, Chapter III (Civil Liberty as Provided in the German Imperial Constitution).

Perris, H. "Germany and the German Emperor," Chapter I (The Four Regions).

Partsch, J. "Central Europe."

DAwson, W. H. "The Evolution of Modern Germany,"

Chapter II (Tripartite Germany)

[12] 


\section{CHAPTER II}

THE FOUNDATION OF THE GERMAN EMPIRE

A UGUST i, 1806, the "Holy Roman Empire A of the German Nation" legally ceased to exist. In the words of a contemporary, since the peace of Münster and Osnabrück it had been nothing but a chimera. It was a rattletrap, a mixture of everything, yet as a whole, nothing. It was everything else in practice from what it was in theory. Voltaire sagely declared it to be neither Holy nor Roman nor an Empire. And so when Napoleon Bonaparte destroyed the dilapidated structure, he only changed a legal, not an actual situation. Francis II abdicated voluntarily August 6,1806 , having already in 1804 accepted the title "Emperor of Austria."

According to its legal structure the Confederation of the Rhine (Rheinbund), into which Napoleon united the states of western and southern Germany was a union of sovereign states under the protectorate of France. The source of its existence was international agreement; in other words, it was a confederation. Its members were recognized as sovereign by the constitution, the Rheinbundacte $(1813-1815)$. The success of the allied arms of Russia, Austria 


\section{GERMAN GOVERNMENT AND POLITICS}

and Prussia in the war of liberation destroyed the Rheinbund before its constitution had actually gone into operation.

The

German Confederation, 1815 1866

At the Congress of Vienna (1815) a new Union including all the German states (at that time thirty-eight) was organized. It was called the Deutsche Bund and was again a union of sovereign states, a confederation. The organic laws of this union were a series of treaties. ${ }^{1}$

According to these treaties between the different German states, governmental authority rested in the totality of the members, i.e., the princes and the free cities. The organ of the Confederation was the Bundesversammlung or Bundestag in Frankfort-on-the-Main, under the chairmanship of Austria. The members of this assembly were diplomatic representatives of their sovereigns, delegates bound by instructions. In acting on ordinary matters each of the eleven larger states had one vote while the smaller ones were gathered into six groups each having one vote. This form of organization of the Bundesversammlung was known as the Engere Rat or smaller council. For constitutional questions and matters of war and peace, the twenty-five smaller states had each one vote while the larger had more, the six largest having four each. Such a session was known as the Plenum. The functions of the Bundestag were: first, legislation, which, how-

1 The Bundesacte of June 8, 1815, and the Wiener Schlussacte of May 15, 1820 .

[14] 
ever did not bind the subjects of the several states directly, but only their respective governments; second, certain international relations; third, military affairs, and fourth, finance for the purposes of the Bund. Those members who refused to execute the resolutions of the common body might be coerced by the armed force of the remainder. This process was known as "Confederate Execution."

Bismarck's caustic exclamation: "O Bund, Du Hund, Du bist nicht gesund!" characterized the situation which existed from the very beginning. The Confederation was ridiculous in Germany and abroad, and its reform or dissolution was inevitable.

The principal cause of the inefficiency of the Bund was the rivalry between Austria and Prussia, each of which great powers was strong enough to dispute the hegemony of the other. Several efforts were made to create a more national and unitary form of government. In 1848 , an official committee of seventeen was appointed by the Bund for the purpose of considering a new constitution. On March 31 of the same year, a conference of prominent Germans inspired by the highest national feeling, was held in Frankforton-the-Main, to undertake the preliminary steps for the creation of a new Empire. This was the so called Vorparlament. It requested the Bundestag to call a National Parliament to be elected by universal suffrage which met at Frankfort-on-the- 


\section{GERMAN GOVERNMENT AND POLITICS}

St. Paul's Main, May 18,1848 . This assembly which is
Parliament

commonly known as St. Paul's Parliament, because it met in a church of that name, adopted in I849 a "Constitution of the German Empire" excluding Austria. After a long discussion, the crown was offered to Frederic William IV of Prussia. But Frederic William declined to accept the crown because of the danger of war with Austria and her allies. At the same time, this aristocratic King, "the romanticist on the throne," had a natural horror of accepting the crown from a liberal and democratic parliament, especially since the constitution gave him very little power. ${ }^{1}$ With his refusal to accept the Crown from liberalism, the liberal national movement came to an end.

A short time later, May 26, 1849, Prussia created the Dreikönigsbund between Hanover, Saxony and herself. This union aimed also at the foundation of a new German Empire under Prussian hegemony with the exclusion of Austria. Hanover and Saxony did not stay in the union very long, but most of the smaller German states entered it. A Diet was called at Erfurt and a draft for a new Constitution had been accepted, when Austria summoned a meeting of the Plenum

Treaty of of the Deutsche Bund and forced Prussia in the Olmütz Treaty of Olmütz of November 29, I 850 , to give

1 See Frederic William IV, "Publicandum to the Prussian People" of May 15, 1849 in "Readings in European History" by J. H. Robinson, New York, 1906, pp. 532 ff.

[ I6] 
up her endeavors to form a new union and to recognize the "reëstablished Bundestag." All hope for a political reorganization of Germany was apparently lost, when Bismarck entered the political arena and accomplished his masterwork, the founding of the new German Empire.

The political union of Germany was preceded by an economic union. In 1818 , Prussia abandoned all customs duties between her several provinces. Then in 1833 , she asked her neighbors to enter into a customs union with her and gradually, because they recognized the benefits of the union, or were forced by commercial pressure, most of the German states joined the "German Customs Union" (Deutsche Zollverein). By 1854 only the Hanse cities, the Mecklenburgs, Holstein and Austria were not members. Financially, Prussia suffered only disadvantages in the Customs Union, but she sacrificed her financial interests to her national policy and was finally highly compensated for it. From that time on there existed, as Treitschke, the Prusso-German historian, says, "two Germanies, a fictitious Germany in Frankfort-on-the-Main, and a real working Germany in Berlin."

Six days after Bismarck became Minister in Bismarck ${ }^{1}$ 1862, he said in the budget committee of the policy up to the

1 Born April I, 1815. Died July 30, 1898. Minister of War with Prussia, Chancellor of the North German Federation, Chan- Austria, cellor of the German Empire, September 24, 1862-March 24, ${ }^{1866}$ 1890. 


\section{GERMAN GOVERNMENT AND POLITICS}

Prussian Chamber of Deputies: "Not by orations and majority decisions are the great questions of the age decided - this was the great mistake of 1848 and 1849 - but by iron and blood." His position as Prussian ambassador at Frankfort-on-the-Main had convinced him that no other way of deciding the German question was possible. He took the "iron and blood" policy as the keynote of his diplomacy, unaffected by the clamor and criticism of his opponents. Knowing that war had to come, he desired to prepare for it. Since the liberal majority in the Prussian Chamber of Deputies, less far sighted than he, refused to give the money for the necessary reorganization of the Prussian army he reorganized it with the consent of his King, but contrary to the will of the majority of the people and in violation of the constitution. Doubtless, if Prussia had not been victorious in the war with Austria, he would have lost his political head. But he was confident of the success of his policy and did not fear anybody or anything. After the triumph of Prussia's army in 1866, public opinion changed entirely and the man, who had been in his own words "better hated than any other man in Europe," became the hero of the German nation. He then easily secured the passage of an act ratifying everything which he had done.

The war was ended by the Treaty of Prague, August 23, 1866. Austria had to give up once and for all any union with the rest of the German [ 18 ] 
states. Prussia annexed Hanover, the Electorate of Hesse Nassau and Frankfort-on-the-Main. It also received Holstein in addition to Schleswig. Austria promised to recognize a closer union (Engeres Bundesverhältniss) between the German states north of the Main.

The foundation of this union is the so-called August Treaty, an international treaty between sixteen states of Germany on the one hand and Prussia on the other. Later on five more states The North

German Federation were added. In this treaty, the parties entered into an offensive and defensive alliance and resolved to form a new union with a constitution, made by the governments of the states, and a parliament called for that purpose. The necessary executive measures were left to the King of Prussia. This agreement was to be valid until the foundation of the new union, but not longer than a year.

In accordance with these stipulations, Prussia offered the draft of a constitution to the twentyone allied states. It is said that Bismarck dictated this project to Lothar Bucher ${ }^{1}$ in one night. The material for it was taken from the Proclamation of Frederic William IV of March 18, I848, the constitutions of the St. Paul's Parliament and of the Erfurt Parliament and the Memorandum of Prussia presented in 1863 to the Frankfort Assembly of Princes. The project was discussed in

${ }^{1}$ Bucher was Privy Councillor, Bismarck's intimate assistant in the Foreign Office. 


\section{GERMAN GOVERNMENT AND POLITICS}

December, 1866, by the delegates of the twentytwo states and accepted. The regulations for the election to the St. Paul's Parliament were adopted as law by the several states. In accordance therewith a Parliament was elected February 12,1867 , by almost the same electorate as prescribed for the Reichstag to-day. Within six weeks of its assembling, this Reicbstag adopted the Constitution with slight changes, April 16, I867.

In order to become law of the several states, the Constitution had to be adopted by the legislative department in each. July I, I 867 was taken as the day on which the Constitution was to go into effect. This is the beginning of the North German Federation. Looking back to the sad constitutional past of the German nation and proclaiming the spirit of the new form of the North German state, Bismarck said in the throne speech at the opening of the first Reichstag (February 24, 1867): "Once the German Empire was mighty, great and respected, because it was united and led by strong hands. But it sank down, dismembered into impotency, not without the fault of its head and parts. Deprived of its authority in the councils of Europe and of the control of its own affairs, Germany became the choice battleground of foreign powers, to whom it gave the blood of its children, battlefields, and war prizes. But never has the longing of the German people for their lost possessions ceased and the history of our times is filled with the [20] 
endeavor to regain for Germany and the German people the greatness of their past.... These endeavors have not as yet led to the goal, this dismemberment has been increased rather than cured, because people have deceived themselves, in regard to the value of the present time, through hopes and memories, and because they have deceived themselves as to the importance of real facts contrasted with ideals. From this, we recognize the necessity of insuring the union of the German people on the basis of facts and not to sacrifice again the attainable to the desirable. The constitutional project placed before you, requires of the independence of the several states, only such sacrifices in favor of the whole, as are absolutely essential in order to protect the peace, to secure the safety of the Federation and the development of the prosperity of its citizens."

Article 79 of the Constitution of the North German Confederation, the famous Main-Bridge, said: "The entrance of the states of southern Germany or the entrance of one of the same The foundation of the German Empire into the Union, takes places upon the motion of the President of the Union, and by legislation of the Federation."

At the same time with the Treaty of Prague a secret offensive and defensive treaty was made by Prussia with the southern states. As a result of it, the southern states assisted the Federation in its war against France. This alliance in war brought about the completion of German unity. 


\section{GERMAN GOVERNMENT AND POLITICS}

Ferro ignique, the German people were united. Already before the war, Baden had asked the North German Federation to be accepted as a member. After the war she repeated her petition, and Würtemberg, Bavaria and Hesse followed. The result of the negotiations were several treaties by which these states joined the Union. ${ }^{1}$

These treaties were made laws of Bavaria, Würtemberg and Baden, in December, $\mathbf{I} 870$. The Bundesrat of the North German Federation with the consent of the southern states proposed to give the new German Federation the name "Deutsches Reich," and to the Prussian King the title "Deutscher Kaiser," as President of the Federation. Amidst the thunder of the cannons which bombarded Paris, William I was proclaimed Kaiser, January I 8, 1871, in Versailles. This event, however, has no meaning so far as the juristic foundation of the Empire is concerned. The foundation of the German Empire dates back to January I, I87I, the time when the constitution of the North German Federation, changed by the November treaties, went into effect in all the states of the union. Sometimes, April 16, 1871, the date of the new redaction of the constitution,

1 The so called "November treaties": The North German Federation and the Grand Duchies of Baden and Hesse, November 15; these states and Würtemberg, November 25; the North German Federation and Bavaria, November 23; the last treaty was joined by the other three southern states, December 8, 1870 .

[22] 


\section{FOUNDATION OF THE EMPIRE}

is given as the date of the birth of the new Empire. However, this redaction did not create a different situation in any point, and thus, January I should be taken as the date of the founding of the Empire.

\section{SELECTED BIBLIOGRAPHY}

Sмгтн, M. "Bismarck and German Unity."

Andrews, C. M. "The Historical Development of Modern

Europe from the Congress of Vienna to the Present Time." 2 vols.

Sybez, H. von. "The Founding of the German Empire by William I." 7 vols.

James, E. J. "The Federal Constitution of Germany."

With an Historical Introduction. 


\section{CHAPTER III}

THE DEVELOPM E T OF THE

The development of the

German Constitution by amendment

\section{CONSTITUTION}

SINCE 1871, the German constitution has $S_{\text {been }}$ changed a great deal, much more so than the constitution of the United States since 1789. Bismarck confidently expected such a development when he produced the fundamental instrument of the Empire. ${ }^{1}$ It was intended to be only the basis upon which a magnificent structure should be erected. Unlike the American constitution, the German constitution is not regarded as a sacred, rigid instrument which can be altered only with the greatest difficulties. Amendments to the constitution are made in the same manner as other laws, the only difference being that fourteen votes in the Bundesrat can defeat any amendment. ${ }^{2}$ This gives Prussia

1 "I credit to our constitution the capacity to develop just as the English constitution has developed, not through a theoretical assertion of an ideal toward which one strives without regard to the obstructions that are in the way, but through the organic development of that which exists, always keeping faces toward the front, making every step in that direction which appears at the moment possible, without great danger." - Bismarck in the Reichstag, March 15, 1877.

${ }^{2}$ Constitution, Article 78, Clause I. Hereafter the official German abbreviation for Constitution e.g., R. V. (Reichsoerfassung) will be used.

[24] 


\section{DEVELOPMENT OF THE CONSTITUTION}

with her seventeen votes, or the three other kingdoms combined, or a group of several of the smaller states the power to defeat any amendment.

Another restriction on amendments is that the privileges of certain particular states may be modified only with the consent of the state affected. ${ }^{1}$ Except for these privileges there is no longer any doubt that any article of the Constitution, including Article 4, which vests the "Presidency" in the King of Prussia, may be amended. The question whether a law is an ordinary law or an amendment of the Constitution, or whether it is contrary to the privileges of a particular state, is decided by a simple majority of the Bundesrat. Since amendments of the Constitution are regarded only as ordinary laws of a special type, the Reichstag has a right to propose them.

The following amendments had been made up to 1914:

I. Article 28, Paragraph 2, was abolished by law of February 24, 1873. Before the passage of this amendment, Reichstag members from states which, on account of special or reserved privileges of these states, were not directly affected by certain Imperial legislation, were not permitted to vote on such laws.

2. Article 4, No. 9, March 3, 1873. The competence of the Empire was by this amendment

1 R. V., Article 78, Clause 2.

2 Compare for a discussion about this question Arndt, A., “Das Staatsrecht des deutschen Reichs," pp. I86 ff. 


\section{GERMAN GOVERNMENT AND POLITICS}

extended to legislation in regard to signals for ocean steamers.

3. Article 4 , No. 13 , changed so as to enlarge the competence of the Empire to give Germany a common civil law, December 20, 1873 .

4. Article 59, Clause I, was changed February II, I888, so as to extend the period of compulsory service from the 32 nd to the 39 th years.

5. Article 24, March 19, 1888. This amendment changed the legislative period from three to five years.

6. Article 53, May 26, 1893. Clause 5 of this article concerning the reserve service of sailors was abolished.

7. Article 70, May 14, I904. The famous "clausula Frankenstein" concerning the exchange of Imperial and state finances was added.1

8. Article 59, Paragraph I, changed on April 15, 1905, so that the active service of soldiers other than cavalry and field artillery was made two instead of three years.

9. Article 32, May 21, 1906. Through this change the members of the Reichstag were granted a remuneration for their service.

Io. Article 38, Clause 2, No. 3, which granted the several states 13 per cent of certain taxes for their collection through state officers, was abolished.

I I. Article 6, May 31, I9r r. This amendment

$$
1 \text { See p. } 139 .
$$

[26] 


\section{DEVELOPMENT OF THE CONSTITUTION}

admits representatives of Alsace-Lorraine to the Bundesrat under certain restrictions. ${ }^{1}$

But not all changes of the Constitution have been made in the form of amendments. Several laws not officially noted as amendments and the operation of custom have also in effect altered the Constitution. June 23, I876, Lauenburg, after September 13, I865, bound to Prussia by a

\section{Change} of the

Const1tution by simple laws and custom personal union, was by a Prussian law united to that state so that the words of Article I "with Lauenburg" are now superfluous. By an agreement of March 2, 1887, Waldeck ceded its administration to Prussia, although it remains a state and may take back its own administration according to the terms of the treaty. The island of Heligoland has been, since 1890,2 a part of German territory. Since February 18, I891, it has been united with Prussia. The Constitution, except section 6, is in force in Heligoland. May 3I, I9II, Alsace-Lorraine, after having been a province of the Empire since $187 \mathrm{I},{ }^{3}$ became part of the German Empire as a new state in the meaning of Article I. The general provisions of Article 3 have been made more specific. Citizenship has been determined by an Imperial law and also the regulations which have reference to the

1 Cf. Chapter XV.

2 Imperial law (abbreviated R. G. = Reichsgesetz) of December 15, 1890 .

${ }^{3}$ R. G. of June 9, 1871 , betreffend die Vereinigung von Elsass-Lothringen mit dem deutschen Reich. 


\section{GERMAN GOVERNMENT AND POLITICS}

care of the poor and their reception into the local communal associations.

In- $\quad$ The Bundesrat has not been changed very much Importance of the Bundesrat as far as its constitutional position is concerned. Prussia has really eighteen votes, since by special treaty, she has the power to instruct also the vote of Waldeck. The connection between Prussia and the Empire has been made closer by the fact that the Secretaries of State of the Empire are usually appointed Prussian delegates to the Bundesrat. The Constitution contemplates only the periodical meeting of the Bundesrat but, on account of the quantity and character of its business, for many years it has been in continuous session. The political importance of the Bundesrat has been lessened by the method in which its business is practically carried on. All the more important projects are first taken up by the Ministers of the different states, especially the different states to which the matter relates. After a majority consensus is thus reached, the proposition is then introduced into the Bundesrat as a mere formality and for the discussion of details.

The The importance of the Reichstag on the other hand, has increased by the increase of the competence of the Empire. The growing expenses of the Empire have tended also to give additional power to the Reichstag through its control of the budget. Fifteen deputies from Alsace-Lorraine have been added to the number of its members. [28] 


\section{DEVELOPMENT OF THE CONSTITUTION}

The growth of the population without any other increase in the number of members has reduced the proportion of deputies to population. The fact that there has been no reapportionment of seats has led to great inequality in the size of the constituencies.

Of all the branches of government, the KaiserThe Kalser has gained the greatest accretion of power. In reality he is no longer what the Constitution intended to make him, a "primus inter pares," but the head of the German government. Every increase of the competence of the Empire is a strengthening of his position. In the first place, he has direction of the federal administration by his appointment of the Chancellor, the Secretaries of State and almost all federal officers. Furthermore, he exercises a great influence upon legislation, not only as King of Prussia, but also as Kaiser. Although the Constitution makes no provision for the initiation of laws by the Kaiser, they frequently emanate from him. Laws with regard to postal, telegraph and marine affairs, etc., must be prepared by Imperial officers, because no state has anything to do with them. These and many other projects are introduced by the Chancellor, the representative of the Kaiser, as Präsidialanträge and now constitute the majority of all bills. Formally, they are Prussian, and are therefore treated like Prussian projects. The Prussian ministry first passes upon them, and only if it approves the bill is it intro- 


\section{GERMAN GOVERNMENT AND POLITICS}

duced into the Bundesrat. The Chancellor therefore must be Prussian Prime Minister, a necessity which will be discussed later in more detail. ${ }^{1}$ The extension of the Constitution to Alsace-Lorraine and the acquisition of colonial protectorates has endowed the Kaiser as head of the Empire with territorial governmental authority in these possessions.

According to Article 17 of the Constitution, the Chancellor was the only officer of the Empire, but soon one Secretariat after the other was created, the heads of which were made responsible substitutes of the Chancellor by the law of March $17,1898.2$ Since this date the heads of these departments have been appointed substitutes, and the Chancellor no longer interferes with the routine work of the departments.

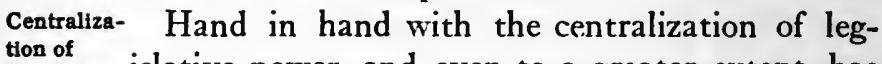
adminisislative power, and even to a greater extent, has trative authority gone centralization of administrative authority. For example, Article 4 gives the Empire only the right of supervision over the legislation enumerated therein. Certain laws, however, have created administrative officers to carry out their provisions. Thus the Patent Office, the Imperial Insurance Office, and numerous other offices have been created.

Except for a few quasi-administrative functions, given to the Bundesrat, the constitution creates nothing in the way of a court. Laws of later years

1 Cf. p. 108.

2 Cf. p. 107.

[30] 


\section{DEVELOPMENT OF THE CONSTITUTION}

have created several administrative courts e.g. the Oberseeamt, the Rayonkommission, etc. ${ }^{1}$ The most important statutory court is the Reichsgericht, the supreme court of the Empire. ${ }^{2}$

The finances of the Empire have been brought into closer connection with those of the individual states. They are forced to administer more and more Imperial legislation, of which they have to bear the expenses. This duty of administering Imperial legislation goes down to the smallest local government divisions.

In military affairs, several extra-constitutional changes have taken place. Military conventions Military centralization between the three kingdoms and Prussia have changed the provisions of the Constitution, so that now there exist four contingents. ${ }^{3}$ The armies of all the states except the three other kingdoms are so closely connected with that of Prussia and so modeled on its example, that in fact these states have no army of their own. Prussia has a military hegemony. Article 60 has been modified by law of May 26, 1893, so that men are recruited from the individual states not by the states themselves, but by the four military contingents.

Since 1893 the size of the army and consequently the expense of its maintenance has increased very rapidly. In consequence, Articles 60 and $62 \mathrm{R}$. V. have been greatly changed.

A complete change has taken place in Article

1 Cf. p. 203.

2 Cf. p. 193.

3 I.e. of Prussia, Bavaria, Saxony and Würtemberg. 


\section{GERMAN GOVERNMENT AND POLITICS}

61. The antiquated Prussian military law was never introduced except in the Prussian contingent. A uniform military criminal law was introduced for the whole Empire including Bavaria December I, I898, and a supreme military court with its seat in Berlin was created above the system of courts of the four contingents.

The military fiskus should theoretically be the individual military fiskus of the four contingents. The law of May 25, 1873, however, transferred the property of all the military administrations to the Empire. Furthermore, the Imperial Civil Service Law (Reichsbeamtengesetz) of May 25, 1873, gave the army officers a right to sue the Empire in its capacity as fiskus. Thus practice has made the military fiskus an Imperial fiskus. Except for Bavaria, the Chancellor was responsible for the military budget. Naturally, this change brought the different Ministers of War of the four contingents as far as the financial side of the army was concerned, under the supervision of the Chancellor. The whole relation is very complicated and might easily lead to conflicts.

\section{SELECTED BIBLIOGRAPHY}

Borgeaud, Charles. "Adoption and Amendment of Constitutions."

Burgess, J. W. "Political Science and Comparative Constitutional Law," Vol. I. pp. $155 \mathrm{ff}$. 


\section{CHAPTER IV}

THE NATURE OF THE GERMAN E M P I R E

TF we should compare the structure of the 1 German Empire with a piece of architecture we cannot find a better comparison than with the old Gothic style. It is a building composed of several parts, great and small. If we take away one of them, the whole loses its character. All the parts are in harmony and help Confederation or federation? to bring out the splendor of the whole. It is purely German in its character, harmonious in style. To make it more venerable, some old statues have been used for ornaments. The parts of the structure are the several states; the great central piece around which the other parts group themselves is Prussia, and the whole is the German Empire. To continue the metaphor, we may say that the foundation of the German Empire did not mean the construction of a new building, but the addition of certain parts, which had to be added in order to complete its architectural beauty.

This view is generally recognized. ${ }^{1}$ It was formulated by the Representative Miquel in the

1 See Arndt, A., "Verfassung des deutschen Reiches," p. 25 . 


\section{GERMAN GOVERNMENT AND POLITICS}

Reichstag December 7, 1870, in the following words: "I look at it this way, that the legal unit possessing property and debts, i.e., the North German Federation is not destroyed, but remains in existence; that other states join the Union in accordance with the Constitution itself, Article 79 , and that therefore, the legal unit remains the same."

The German Empire is therefore nothing but the legal successor of the North German Federation. We solve the problem of the nature of the German Empire by solving that of the North German Federation. On the other hand, the question of the nature of the German Confederation of 1815 to 1866 , offers no problem for the jurist. It is only disputed by a few historians, who deny the existence of non-unitary states. ${ }^{1}$ It is almost universally recognized that this old German Bund was a confederation, i.e., a union of sovereign states, bound by treaties of international character.

View of Seydel

The generally accepted view, however, that the North German Federation, and consequently the German Empire, was a federation was disputed by a very able young Bavarian professor, Max Seydel. The arguments against Seydel's standpoint were led by Prof. Albert Hänel. Both received, as they themselves confess, most valuable suggestions from the two great American

1 E.g., Kloeppel, "Dreissig Jahre deutscher Verfassungsgeschichte."

[34] 
statesmen, Calhoun and Webster, and it would be interesting for someone familiar with the constitutional law of both countries to show in detail the influence of these Americans on the German theorists.

The difference of opinion in the United States became of immense practical importance in connection with economic and social questions and led to a bloody decision in the Civil War between the Northern and Southern States, which settled the difference of opinion unquestionably in favor of Webster's point of view. No such terrible danger of civil war ever arose in the German Empire, because of the preponderance of Prussia, but nevertheless it is all important from the point of view of political science to decide this cardinal question.

Let us first follow the arguments of Seydel and his followers. In 1872 an essay appeared in the "Tübinger Staatswissenschaftliche Zeitschrift" (pp. I85 ff.) by Seydel, which immediately made a name for its author. In this article he discussed the conception of a federation, which had been constructed by the well-known historians Waitz and Toqueville, and which was once universally accepted and is still to a great extent in the United States. This conception divided sovereignty and gave part of it to the Union and part of it to the several states. Seydel in his famous, forceful article showed that division of sovereignty is philosophically illogical. Supreme 


\section{GERMAN GOVERNMENT AND POLITICS}

power, a superlative - he asserted - excludes the possibility of any division. So it must belong

Soverelgnty Indivisible

\section{outright to the states or to the Union. This} reasoning of Seydel's is not entirely new. Before him, Bodin and the great jurist of the Law of Nature, Samuel von Pufendorf, had spoken decidedly against the possibility of the division of sovereignty, but their views had been entirely neglected. Since according to this argument there can be only the sovereignty of the Union or of the states; there is no such institution as a federation. The state is either a unitary state or a confederation, and as Germany, of course, is no unitary state, it is a confederation. According to Seydel's opinion, the single states are sovereign and the Union a temporary one based on a contract, from which they may retire as soon as they desire. This contract is embodied in the so-called August Treaty.

Sovereignty not an essential element in the

Against this theory many objections can be raised. In the first place: Is sovereignty an essential element for the conception of a state? We deny it. There exist sovereign and non-sovstate ereign states - only the first, to be sure, being recognized as the legal subjects of international law. We replace sovereignty as the essential element of statehood by Staatsgewalt, "original governmental authority." Assuming this view, Seydel's theory, which abolishes that union of non-sovereign states which is called a federation, is disproved. The German states are real states [36] 
with all the qualities of such, with governmental machinery and laws binding individuals and corporate bodies under their government, but they are not sovereign.

When Dr. Du Buy ${ }^{1}$ spoke of his surprise on hearing for the first time that the German Empire should properly be called the German Republic he Monarchy or polyexpressed the opinion of every student beginning his study of German constitutional law. Those who have only a vague idea about the Constitution of the German Empire get the idea from their newspaper reading that the Kaiser is the monarch of the Empire, the Bundesrat the upper house and the Reichstag the lower house. This idea, held by nearly all foreigners, is absolutely and completely wrong.

Section IV, Articles II-I9 of the Constitution, deals with the position of the Kaiser and bears the headline: "Praesidium of the Federation." The first sentence of Article II reads, "The praesidium of the Federation is given to the King of Prussia, who bears the name of German Kaiser." The Constitution does not make a monarch of the Kaiser, but simply confers on him certain limited presidential powers, much less extensive, indeed, than those of the President of the United States. The power of the Kaiser does not lie in his position as President of the Federation, but as the sovereign of the strongest member of the Federation. Suppose the presidency were given to some small 1 "Two Aspects of the German Constitution." 


\section{GERMAN GOVERNMENT AND POLITICS}

state like Reuss, older line. It would be clear then, how little the presidency means. Per se the position of Kaiser is of little importance. He has no rights of sovereignty. He has only formal powers in the making of laws. The makers of the constitution objected to the title "Kaiser of Germany" because that title could have been interpreted to mean that the Kaiser was sovereign monarch of the Empire. And Bismarck declared several times in the Constitutive Imperial Diet of the North German Federation that sovereignty did not belong to the Kaiser. Imperial sovereignty rests with the twenty-six members of the Federation in their "totality." They have always, through that organ of the Empire, which peculiarly represents them, the Bundesrat, the last word in expressing the will of the Union in laws, including constitutional amendments. Thus Germany is not a Monarchy but a Polyarchy.

It has been questioned whether the members of the Bundesrat are the states or the princes. This problem will be discussed later on. For the present, it is only necessary to note the actual condition. With the exception of three republics, the free cities, the German states are monarchies, in which the reigning princes are sovereign and have therefore the right to determine the representation of the state in the Bundesrat. Hence, its members are with the exception of three, delegates of reigning princes. The Empire is therefore an aristocracy. It is an aristocratic polyarchy. 
The Constitution of the German Empire does not establish the parliamentary form of government. It may be that in the far future the English form of the political responsibility of the

Parliamentary or presidential government? Chancellor of the Empire will gradually be introduced. The parties of the Left in the Reichstag are pleading for it. But until now, no real tendency towards the parliamentary form of government can be observed, in spite of the wishes of the Liberal, Radical and Social-Democratic Parties. Of course, if a chancellor is permanently without the support of a majority in the Reichstag, so that no legislation is possible, it is clear that he must give up his position. This was the case with Prince von Bülow. He had excited the opposition of the majority in the Reichstag - the "Blue-Black Bloc," i.e., Conservatives and Clericals - so that they refused to compromise with him in his financial reforms. The Imperial Government is supposed to be above parties and take its majority from all, its leading motive always being the welfare of the whole. And although the Secretaries of State of the Empire have mostly belonged to the Right Wing of the Reichstag, nevertheless sometimes men of Liberal view have been appointed Secretaries, e.g., Dernburg, and Wermuth now mayor of Berlin. Bismarck in the Prussian Chamber of Deputies, May 7, 1886, said: "One who is not Minister may permit himself the luxury of representing publicly and officially a party opinion; in a ministerial position 


\section{GERMAN GOVERNMENT AND POLITICS}

as leading Minister, I cannot accept a party view permanently; I may believe it useful for the country to emphasize sometimes one, sometimes another; however, I cannot permanently belong to one party, but I have to ask myself always, what is, at this moment, rebus sic stantibus, useful, what serves the end, what is best for the whole country? . . . and according to that I shall have to make my propositions, in spite of attacks partly bitter and unjust." ${ }_{1}$

In forming the Union, the states gave up Relation their sovereignty and received for it a "share in of the

Empire to the states the sovereignty of the Empire." Giving up their sovereignty they did not give up their statehood. They still possess original governmental authority

1 "In the year 1885 , when the old Kaiser was seriously ill, Bismarck had a conversation with the Crown Prince. Many expected a gradual change to the parliamentary form of government, in case the Crown Prince should succeed his father. Under those circumstances, it would have been impossible for Bismarck to remain in office as the Prince wished. Therefore, he promised to continue his chancellorship only under the condition, that the new Kaiser would be opposed to a parliamentary government. Energetically, the Crown Prince said, 'No idea of it!'” (i.e., parliamentary government). - Bismarck, "Gedanken und Erinnerungen," Vol. II, pp. 304-305.

"A leading Minister always needs the help of parties but he can never subject himself to the rule of a party." - Bismarck in a speech in the Reichstag of July 9, 1879.

"In Germany, the Ministers are not organs of the Parliament and of its temporary majority, but they are the entrusted representatives of the Crown," etc. - Bülow in a speech in the Reichstag of November 14, 1906. 
and not until all of these powers are taken away from them will they be provinces of a unitary German state. Already many powers have been taken away from the several states and the German Union has more powers than the American Union. These subjects of Imperial legislation are enumerated in Article 4 of the Constitution. All other powers are left to the states, as: making their constitutions as long as they are not contrary to the Imperial Constitution, regulating their own finances, making laws relative to religion, public instruction, public meetings, water and road rights (as far as the Empire has not competence), credit of the state, agriculture, breeding of animals, forestry, mining, hunting and fishing. But as soon as a law of the single state becomes contrary to the law of the Union, the rule is: "Reichsrecht bricht Landesrecht" (Article 3), i.e., federal law takes precedence.

With regard to the administration of the broad legislative powers of the Empire, Germany differs entirely from the United States. For while in the latter the laws made by the Union are also executed by it, in Germany their execution is mostly left to the officers of the single states. This is not laid down by the constitution as a principle, neither is there a fixed system according to which the relation of legislation and its administration is regulated. Only considerations of convenience are employed in deciding this question. Foreign affairs, Postal and 


\section{GERMAN GOVERNMENT AND POLITICS}

Telegraph matters and the Imperial Bank are completely or almost completely administered by the Empire.

Finally Imperial laws are passed in very general terms while detailed legislation in conformity with them is left to the several states. In all these cases, however, the Empire has the right of supervision, in order that all legislation may be in harmony with the legislation of the superior authority.

The competence of the union is limited by the

Privileges of certain states special privileges given to Bavaria, Würtemberg, Baden, Alsace-Lorraine, Bremen and Hamburg. These exceptions however, not being essential, only prove the general rule. It would be wrong theoretically to declare the union non-sovereign because it has no right to take away these privileges. They may be abolished, only with the consent of the state itself in the Bundesrat. These privileges are generally grouped into two classes: Special privileges (Organisationsprivilegien, Verfassungssonderrechte) and reserved privileges (Reservatrechte, Exemptionsprivilegien). To the first class belong those special rights which give to a state a certain position in the organization of the Empire, e.g., the hereditary right of Prussia, that its Crown be always joined with that of the Empire, the right of each state to have a certain number of votes in the Bundesrat, as enumerated in R. V., Article 6, the right of Bavaria to preside in the Bundesrat as substitute for Prussia, the [42] 
right of Bavaria, Saxony and Würtemberg to be always represented in certain committees of the Bundesrat (R. V., Article 8). Reserved privileges on the other hand are all those which exempt a state from the legislation and supervision of the Union in regard to a matter which otherwise is, or may be, regulated by the Union. Of these privileges, Bavaria has a good many: domicile and settlement in relation to poor relief (R. V., Article 4, $\mathrm{I}^{1}$ ); railroad regulation (R...V., Article, 42-46); military matters; legislation with regard to post and telegraphs, and the enjoyment of the income therefrom (as given in R.V., Article 52). Würtemberg has this privilege and also some privileges of minor importance in regard to the organization of its army. (R. V., "Schlussbestimmung," Section XI.) Bavaria, Würtemberg and Baden have the right to levy taxes on wine and beer produced in their territory the income from these taxes going into their treasuries. (R. V., Article 35.) A similar privilege in regard to spirituous liquors has been abolished with the consent of these states. (Law of June 28, I887, Paragraph 47.) R. V., Article 34, gives Hamburg and Bremen a large territorial region 1 "The following matters shall be under the supervision of the Empire, and subject to Imperial legislation:

"Regulations with respect to the freedom of migration, matters of domicile and settlement, etc. . . so far as these matters are not already provided for in Article 3 of this Constitution, in Bavaria, however, exclusive of matters relating to domicile and settlement." 


\section{GERMAN GOVERNMENT AND POLITICS}

of exemption from the customs duties of the Empire. The greatest part of this zone came under the entire authority of the Union February 16,1882 , and March 31, I885, upon the motion of these two Hanse cities. There is, however, still a small free port in connection with each city.

\section{SELECTED BIBLIOGRAPHY}

Burgess, J. W. "Political Science and Comparative Constitutional Law," Vol. I, pp. 120 ff.; pp. I 58 ff.; Vol. II, pp. $27 \mathrm{ff}$.

Howard, B. E. "The German Empire," Chapter II (The Empire and the Individual States).

Hudson, R. "The North German Confederation." In "Political Science Quarterly," Vol. 6I.

Du Buy, J. "Two Aspects of the German Constitution." Shephard, W. J. "Tendencies toward Ministerial Responsibility in Germany." In "The American Political Science Review," Vol. V, No. I.

Lowell, A. L. "Government and Parties in Continental Europe," Vol. I, pp. 242 ff. 


\section{CHAPTER V}

T H E R E I C H S T A G

$\triangle$ RTICLE $_{4}$ of the Constitution enumerates 1 in sixteen paragraphs the field of Imperial legislation in which the Reichstag participates. Comparing it with the legislative power of the United States we find that of the German Empire greater and more important. The tendency toward centralization is much stronger than in the United States.

Article 5 declares that the Reichstag is a coordinate factor with the Bundesrat in Imperial legislation. The former has not only the right to participate in legislation proposed by the Bundesrat, including the budget, but it may also initiate legislation. As a matter of fact, however, most legislation originates in the Bundesrat.

The approval of the Reichstag is also necessary for Imperial loans and for the validity of certain ordinances, where, in the law providing for the use of ordinance power, it has reserved to itself this right of approval. Treaties become binding on citizens only if passed as laws by the Reichstag. The Reichstag cannot be prorogued for more than thirty days, nor more than once during the same session without its own consent. The govern- 


\section{GERMAN GOVERNMENT AND POLITICS}

ment must in certain cases, especially financial administration, report to the Reichstag. It may, or in some cases must, approve or disapprove the report. Furthermore the Reichstag has the right as a body to petition the Chancellor or the Bundesrat to call attention to necessary legislation or administration. Finally, the Reichstag, like most legislative bodies, is the judge of the election of its members, makes its own rules for the conduct of its business, and elects its President, Vice-President and Clerks.

The Reichstag is chosen by universal adult male suffrage, secretly and directly exercised. ${ }^{1}$ The Elections franchise is fundamentally that of the constituto the Reichslag tion of 1849 . Its creation was a radical measure even in 1867 , especially when we consider that Karl Marx and the young Bebel were opposed to it. They did not expect much from it; for looking at France they saw its abuse under the régime of Napoleon III, who legitimized all his actions by force elections. However Lassalle, the genial socialistic demagogue, foresaw the immense value of universal suffrage under an honest government and for the organization of a political party of workingmen, and by his forceful personality he had an influence upon Bismarck's determina-

1 The details of franchise and constituencies are regulated by an ordinance of the Bundesrat of May 28, 1870 (with amendments of February 27, 1871, December 1, 1873 and April 28, 1903) based upon an election law of May 31, 1869. R. V., Article 20, Paragraph I, gives the general principles.

[46] 


\section{THE REICHSTAG}

tion to introduce universal suffrage for the election of the Reichstag.

Both men were great enemies of the old liberalism, which they intended to defeat by universal suffrage. But while Lasalle sought to destroy the bourgeoisie by the votes of the industrial workers, Bismarck counted on the conservative mass of the country population. The result has proved that both were correct. With the immense development of industry and the promulgation of socialistic ideas, the mass of the liberal element has deserted the party of that name and turned to the socialistic party, while the rural population is the stronghold of conservatism. The old Liberal Party now is without decisive power. Advocating universal suffrage, the Liberals dug their own grave. They were theorists, not politicians.

Quite often, recently in particular, as an offset to Liberal criticism of the Prussian Three-Class System, the Reichstag franchise has been attacked by Conservatives, as most unjust, because it equalizes the votes of the educated and the ignorant, of the rich and the poor. But the government has always upheld universal suffrage as the best and most natural suffrage for the popular representation of Germany. Defending universal suffrage, Bismarck said in the North German Reichstag, March 27, I867: "Universal suffrage has come to us in a way, as an inheritance from the development of the German desire for unity; we 


\section{GERMAN GOVERNMENT AND POLITICS}

had it in the Constitution, as it was drawn up at Frankfort; we confronted Austria with it in I866, and I can only say that I at least know of no better electoral law. ... The solid mass of population should predominate at the elections."

According to Paragraph 5 of the Election Law,

Constituencies

a population of 100,000 was to elect one representative with the proviso that each state was to have at least one representative. A surplus of 50,000 was to entitle the state to another representative. Prussia received 235, Bavaria 48, Saxony 23, Würtemberg 17, Baden 14, Hesse 9, Mecklenburg-Schwerin 6, Mecklenburg-Strelitz I, Oldenburg 3, Braunschweig 3, Saxe-Meiningen 2, Saxe-Altenburg I, Saxe-Koburg-Gotha 2, Anhalt 2, Schwarzburg-Rudolstadt I, Schwarzburg-Sondershausen I, Waldeck I, Reuss older line I, Reuss younger line I, Schaumburg-Lippe I, Lippe I, Lauenburg I, Lübeck I, Bremen I, Hamburg I, Alsace-Lorraine I5.

The last clause of the section referred to provided that the adjustment of the number of representatives to an increasing population should be settled by law. However, in spite of the enormous concentration of the German people in cities in consequence of industrial and commercial development, the constituencies have remained the same, so that now the sixth district of Berlin represents 219,780 , Bochum I63,000, TeltowBeskow-Storkow 338,800, while Deutsch Krone [48] 


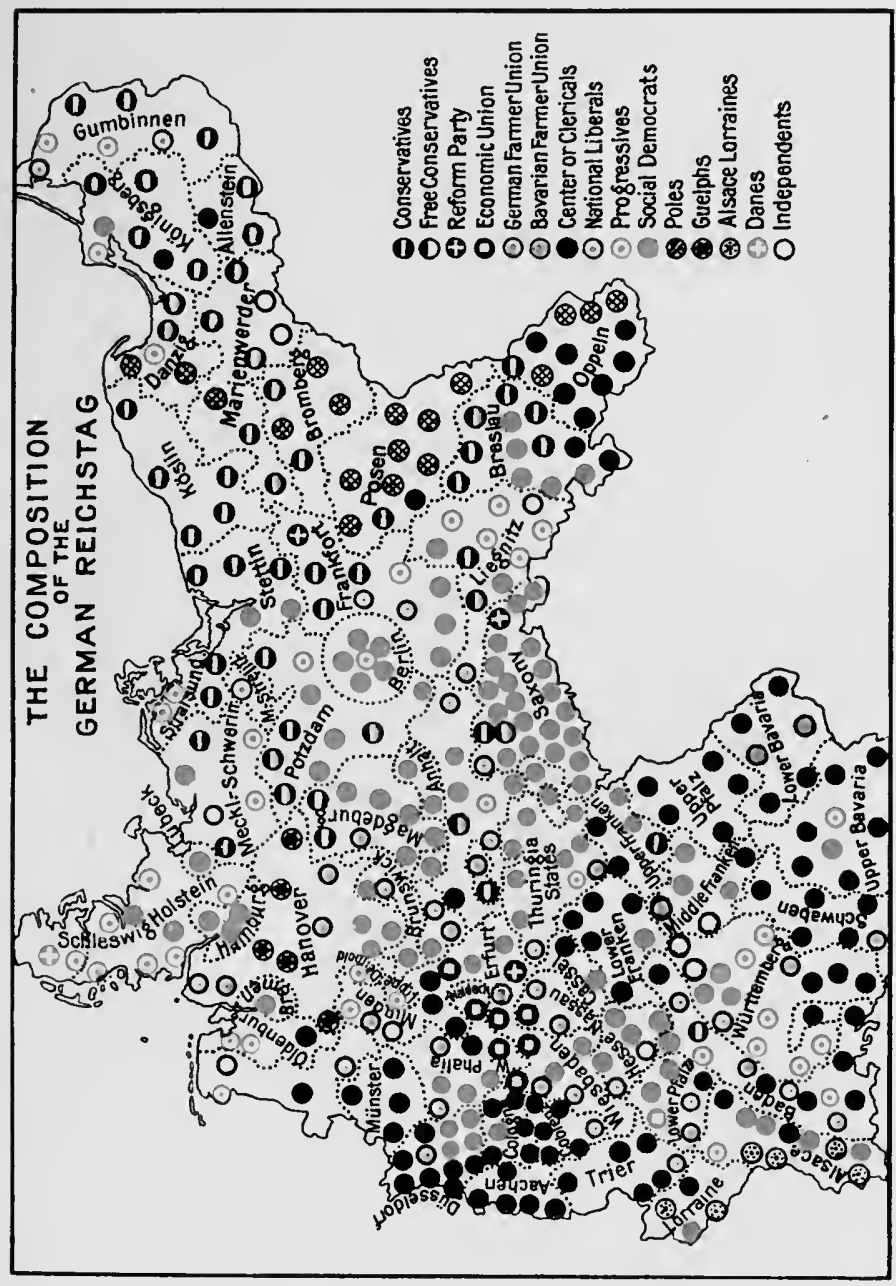



represents only 12,990, and Lötzen-Angerburg I 5,500 qualified voters.

Undoubtedly if the franchise is to be treated as a question of arithmetical exactness, there exists great political injustice in this apportionment of representation. This is the opinion of the parties of the Left, especially of the Social-Democrats who have time and again demanded a reform of constituencies. But the government and the conservative parties are of the opinion that the Reichstag should represent the different classes. If on the arithmetical basis of population the constituencies were changed, industry would have too big a representation as compared with agriculture. For example, the groups of the Conservative Party having 74 deputies in 1912 represented I,933,000 voters, while the Socialists with IIO seats were supported by 4,250,000 voters. In other words, the Social-Democrats would have more than twice as many deputies as the Conservatives in case of an arithmetical redistribution.

Of the 397 constituencies 243 are rural, i.e., districts in which the majority of the population lives in communities of less than 2,000 inhabitants. Of these the Liberals have 60 , the Conservative Groups 67, the Clerical Group 92, and the Socialists only 24 , all secured in I9I2. Of the 154 urban districts, the Social-Democrats have 86, the Liberal Groups 32, the Conservative Groups only 5, and the Clerical Group 3I. 


\section{GERMAN GOVERNMENT AND POLITICS}

Every male German citizen who has finished his Qualif- twenty-fifth year is a qualified voter in the state cations and disquallfications for voters and constituency where he resides. The right to vote is suspended for persons active in military or naval service of the army or the navy, excepting so-called Militärbeamte (Chaplains, Judges, etc.). The following classes are disqualified from voting:

I. Persons who are under guardianship.

2. Bankrupts, during the process of bankruptcy.

3. Persons who have received alms from public or communal funds during the year preceding the election.

Any qualified voter who has been a citizen of any of the states of the Union for one year may be elected to the Reichstag.

The date for the elections, which in general The elections has to be the same for the whole Empire, election is fixed by an Imperial ordinance. Special elections, which in other respects are treated like general elections, take place if the person elected does not accept the election, if his election is declared void, or if his seat becomes vacant during the legislative period. Each constituency is subdivided into districts. In each district lists of the qualified voters have to be made and deposited for public inspection. This has to be done at least four weeks before the election occurs. Objections to the list may be raised within eight days. Only persons registered may vote. In case of special elections, which take place within one [50] 
year after the general elections, new election lists are not necessary.

The election board consists of a chairman, his substitute, a registrar and three to six adjuncts. All these offices are honorary and unpaid and may not be held by officers directly in the service of the state. The envelope for the ballot must be the same for every candidate. The election begins at Io A.M. and ends at 7 P.M. After the election is over the votes are counted by the election board. The record of the election and all documents pertaining to the election are then sent to the election commissioners of the constituency, who are nominated by the superior administrative authority. On the fourth day after the election, the result must be published in the official papers.

An absolute majority is necessary for election. If no candidate has a majority a new election, not later than fourteen days after the general election, takes place between the two candidates who received the highest number of votes. This is called a "Stichwahl." A tie is settled by lot. The expenses of the election are paid almost entirely by the constituency.

The Criminal Code of Germany protects elections to the Reichstag. Its provisions read as follows:

Special protection of elections

"§107, He who by force or by threat with a criminal act prevents a German from exercising his civil right to elect or vote, will be punished with 


\section{GERMAN GOVERNMENT AND POLITICS}

imprisonment for not less than six months or with confinement in a fortress for not less than five years."

" $\$ 108, \mathrm{He}$ who in the exercise of a public duty is charged with the collection of ballots or with the preparation of the announcement of the result of the election, and intentionally brings about a wrong result of the election or falsifies the result will be punished with imprisonment of from one week to three years."

"If the act be committed by a person who is not charged with the collection of ballots or other duty in connection with the election, the same is subject to imprisonment for not more than two years."

"He may also be deprived of his civil rights."

" $\$$ rog, He who purchases or sells a vote in connection with a public transaction, will be punished by imprisonment for from one month to two years; he may also be deprived of his civil rights."

The Reichstag is judge of its own elections. Settle- The first investigation of the returns, which are disputed elections transferred to the Reichstag by the different states, is made in the seven sections (Abteilungen) of the Reichstag, 1 to which the different returns are distributed by lot. In case of any objection in these sections, the validity of the election is determined by a special committee of the Reichstag (Wahlprüfungs-Kommission), which is elected for ${ }^{1}$ See p. 54 .

[52] 


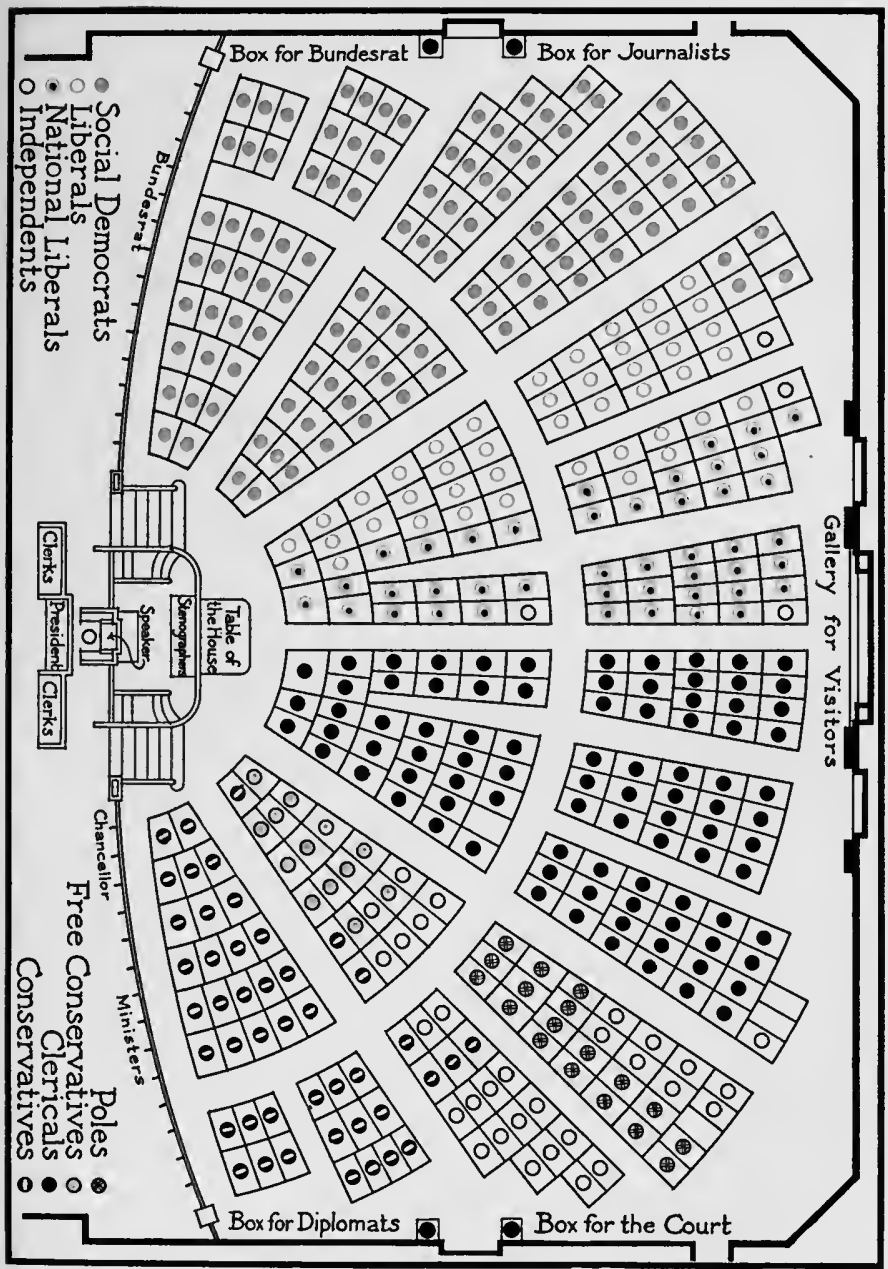



each session. Until a decision is reached, the deputy elected on the face of the returns, retains his seat.

As in all the continental European countries, the seats of the Reichstag are arranged in a semicircle, faced by the platform for the speaker and the presiding officer and other officers of the Reichstag. To the left and right are seats for

Organization of the Reichstag members of the Bundesrat.

Viewed from the speaker's platform we find the conservative parties on the right wing, the Clericals next, to the left the liberal groups and on the extreme left the Socialists, from which location results the naming of the "Right" (Conservatives), the "Center" (Clericals), the "Left" (Liberals), and the "Extreme Left" (Socialists).

At its first meeting, a new Reichstag is called to order by the senior member as President pro tem. As soon as a quorum is present, the Reichstag elects a President, two Vice-Presidents, and eight Clerks. The presiding officers are elected for a period of four weeks at the beginning of each new Reichstag, then for the rest of the session and at the beginning of each following session for the whole session. The Clerks are elected for one session.

The presiding officers are naturally taken from the majority, or if there is no one party-majority, Presiding Officers from a coalition of parties furnishing a majority. So far the Conservatives have had six Presidents, the Free Conservatives one, the National-Liberals 


\section{GERMAN GOVERNMENT AND POLITICS}

two, the Clericals three, and the Liberals one. The Socialists succeeded for the first time in 1912 in electing one of their members as first Vice-President. The presiding officers are for the most part prominent members of their party although not the leaders. They are supposed to and generally do perform their duties impartially. Besides their duty of presiding over the meetings they have the right to be present at the meetings of the committees and the sections, to appoint the administrative paid officials of the Reichstag and from among the members two Quaestors for the supervision of the finances of the Reichstag.

To keep the House to the orderly prosecution of its business, the presiding officers may call a member to order. In case of frequent violation of parliamentary rules the member may be reduced to silence following a resolution of the Reichstag, or in case of a serious disturbance he may be removed from the meeting. If the House is totally in disorder the President may close the meeting. Spectators have no right to applaud or show any sign of discontent. To enforce this rule, the balconies may be cleared at the order of the presiding officer. The order in the Reichstag is in general as good as that of the most decorous parliaments. The most disturbing element is the Social-Democrats.

At the opening of the Reichstag the members

Sections and committees are divided by lot into seven equal sections or Abteilungen. These Abteilungen make the pre-

[54] 
liminary investigation of the validity of the elections. ${ }^{1}$ The Abteilungen are permanent unless recomposed at the request of fifty deputies. Furthermore they have in their hands the formation of the committees. Each elects an equal number of men to each committee (Kommission). The only permanent committee for the duration of the session, is that for the detailed investigation of elections. Each committee elects a chairman, a clerk, and a member to report the result of its deliberations to the Reichstag. ${ }^{2}$ The report is either oral or written. It must be written if so requested by a majority of the Reichstag. Any member may be present at the meetings of a committee unless the Reichstag decides to exclude all who are not official members. Members of the Bundesrat and their representatives must always be admitted as deliberating members and the Chancellor must be notified of the subjects under discussion. Thus a needful amount of publicity in the committees is provided for.

The order of speakers is fixed by the presiding officer, but he must arrange them according to the order in which they have asked for a participation in the discussion. Those who bring in a bill or a report of a committee must always by request be heard at the beginning and end of the discussion. The speakers speak either from their

${ }^{1}$ Cf. p. 52.

2 As to the importance of the committees, see p. Ir 3 . 


\section{GERMAN GOVERNMENT AND POLITICS}

seats or from the speaker's platform. Speeches must not be read unless the speaker is not able to speak in German.

The adjournment of the meeting and the end of the debate is decided by the majority of the Reichstag at the request of any thirty members. Vote is taken according to the rules generally known in legislative bodies.

The Reichstag has the right of interpellation of the Bundesrat. Thirty members have to second the interpellation. But, since the Chancellor and the Bundesrat are not politically responsible, the interpellations would be more correctly termed questions. If the Chancellor wishes to answer the question he sets the date for the answer. This may, on the request of fifty members, be followed by a general discussion. The vote of the members of the Reichstag upon the answer - a formality recently added to the rules - is in reality meaningless. Addresses to the Kaiser may be sent or personally transmitted to him, in which case the president of the Reichstag alone is the speaker. ${ }^{1}$

Members of the Reichstag retain their seats for Legal five years, unless the chamber be sooner disposition of the members solved. They are free to resign any time. A of the Reichstag member loses his seat if he accepts a salaried official position for the first time, or, if an officeholder when elected, is appointed to a higher position, the theory being that the 1 About the passage of a bill see in detail Chapter VII. [56] 


\section{THE REICHSTAG}

conditions under which he received the confidence of his constituents have been changed.

The members of the Reichstag are given the following privileges, by the Constitution:

"Article 30. No member of the Reichstag shall at any time suffer legal or disciplinary prosecution on account of his vote, or on account of utterances made while in the performance of his functions, or be held responsible in any other way outside of the Reichstag."

"Article 3I. Without the consent of the Reichstag, no one of its members shall be tried or arrested during the session for any penal offense, unless he be taken in the commission of the offense, or during the course of the following day. Like consent shall be required in the case of arrest for debt."

"At the request of the Reichstag all criminal proceedings instituted against one of its members, and all detentions for the purpose of judicial inquiry or in civil cases, shall be suspended during its sessions."

The deputies in the Reichstag are not in legal contemplation bound by the instructions of their states or constituencies. The Constitution, (Article 29) expressly states that "the members of the Reichstag are the representatives of the people as a whole, and shall not be bound by orders or instructions." As a matter of fact they do not occupy themselves with local legislation pleasing to their districts to the neglect of ques- 


\section{GERMAN GOVERNMENT AND POLITICS}

tions of general welfare to any such degree as do Representatives in the Congress of the United States, or the members of the lower houses in France and Italy.

Until May 21, 1906, the deputies received no remuneration for their service in the Reichstag. It was Bismarck's opinion that salaries would induce the deputies to prolong sessions. Since a deputy is obliged to give almost his whole time to his activity in the Reichstag, many who would have made excellent candidates hesitated to seek election to it. On the other hand it was feared that the payment of members would create a class of professional politicians. Bismarck desired the Reichstag to represent all the different interests of Germany, industry, agriculture, labor and the professions. ${ }^{1}$ The sessions of the Reichstag, however, proved to be poorly attended, often failing of the necessary number to carry on the business of the body. In the hope, therefore, of securing a greater share of the time of members for their representative duties they were given an annual salary of 3,000 marks $\left(\$ 75^{\circ}\right)$ from which the sum of twenty marks is deducted for every meeting not attended. In addition they were continued in the privilege formerly enjoyed of free transportation on the German railroads. Unfortunately the introduction of salaries has not had the desired result. The salary itself, one tenth that of members of

1 Compare his speech in the Reichstag of April 19, 1871.

$\left[5^{8}\right]$ 


\section{THE REICHSTAG}

the Congress of the United States, seems rather inadequate and free transportation encourages running home on the slightest pretext.

The St. Paul's Parliament of 1849 at Frankfort-on-the-Main was one of the most remarkable popular representative bodies the world has ever seen. The intelligence of all Germany was assembled to discuss the future of the country, and The personnel of the Relchstag in theoretical depth its discussions have never been surpassed. But unfortunately it was too theoretical. Its members took too much pleasure in the brilliant scintillations of oratory. They followed vague ideals, defending them with dogmatic fanaticism, scorning to seek the attainable through compromise. Their bad example, unrelieved by their brilliancy, was followed by the Prussian House of Representatives in the period intervening before the establishment of the North German Confederation. When after the wars of 1866 and $1870-7$ I the German Empire was created, a new problem arose for the representatives of the people. They had to help build up the great structure, the foundations of which had been laid by Bismarck. This work attracted again the ablest political minds of the Germans. Thus the first Reichstag contained a number of fine personalities and the average capacity of its members was relatively high. Gradually, however, it has declined. After the great national problem, the inner unification of the Empire, had been dealt 
with, the detail work of legislation with all its petty struggles began. The parties lost their national character and became the representatives of special economic and social classes. Disgusted, many men of statesmanlike qualities and high ideals turned away and left the seats in the Reichstag to average politicians. A great deal of this decline in personnel is due to the growth of the Social-Democratic party. Although they count some excellent parliamentarians among their members, the average Social-Democratic deputy is a man of comparatively little education and of narrow views. The Reichstag, it is generally conceded, has disappointed the hopes of the more intelligent people. Nevertheless, it compares favorably with other legislative bodies.

Eighty-three of the IIo Social-Democratic members were formerly workingmen or employees.

Of the teaching members 7 are university professors and the same number professors of intermediate schools. The judges are most of them of high rank. Among the state officers there are I former Secretary of State, 3 Privy Councilors and I Councilor of Legation.

The number of members of the nobility has steadily decreased. While the Reichstag of the North German Federation contained a majority of noblemen the present Reichstag has only 57, of whom 27 belong to the Right, I4 to the Center and Guelfs and 8 to the Poles One hundred and

[60 ] 


\section{THE REICHSTAG}

eighty-nine members have served in the army; 80 were officers of the reserve, among them 2 generals. This fact is of importance, since military legislation is one of the most important parts of German legislation and the Reichstag should have enough experts to judge of the government projects and the administration of the army.

The following diagram gives a general idea of the occupations of the members of the Reichstag in 1912.

\begin{tabular}{l|l|c|r|r}
\hline Agriculture & Industry & Commerce & Trade & Unskilled Labor \\
\hline $\begin{array}{c}88 \\
\text { 4I members belonged } \\
\text { to the conservative } \\
\text { groups, none to the } \\
\text { Socialists. }\end{array}$ & 5 & I7 & $2 \mathrm{I}$ & $\begin{array}{c}\text { Only one member } \\
\text { belonged to the } \\
\text { Socialists. }\end{array}$ \\
\hline
\end{tabular}

\begin{tabular}{|c|c|}
\hline Petsons living on their private means & Professions \\
\hline 13 & $\begin{array}{l}250 \\
58 \text { were writers and journalists ( } 43 \\
\text { of these were Social-Democrats); } \\
21 \text { clergymen ( } 20 \text { of these were } \\
\text { Catholic priests); } 22 \text { professors and } \\
\text { teachers; } 8 \text { physicians and apothe- } \\
\text { caries; } 39 \text { lawyers; } 24 \text { judges; 2I } \\
\text { state officers; } 7 \text { communal officers; } \\
50 \text { professional employees or Privat- } \\
\text { beamte. }\end{array}$ \\
\hline
\end{tabular}

Two hundred and six of the deputies had an academic graduate training, 61 of the Clericals, 


\section{GERMAN GOVERNMENT AND POLITICS}

30 National Liberals, 27 Socialists, 26 Liberals, 20 Conservatives, etc.

Count Kanitz (Conservative) and Bebel (Socialist) ${ }^{1}$ are the only members who have belonged to the Reichstag since the time of the North German Federation. Besides these two men there is one Clerical who has had a permanent seat in the Reichstag since 1871. Eight of the present members have had a seat since the 70 's, but with intermissions. Two hundred of the deputies elected in 1912 had not belonged to the preceding Reichstag, out of which number however 37 had belonged to some other Reichstag. As to the age, there were two older than 80 years, $x_{3}$ between 70 and 80,126 between 50 and 60,143 between 40 and 50 and 2 under 30 years of age.

In regard to religion the present Reichstag contained 180 Protestants, 130 Catholics, 69 Dissidents (all Socialists), 8 Free Thinkers and I Free Catholic (all Socialists), 7 Jews, and one whose religious affiliation is not given.

Most of the deputies have had some previous political training in the service of cities or other local government divisions.

These data show that the German Reichstag, though not a body of well-trained statesmen, is nevertheless a fair representative assemblage of all the different types of German voters and stands comparison with any second legislative chamber in the world except the English House of Commons.

1 Both men died recently.

[62] 


\section{THE REICHSTAG}

\section{SELECTED BIBLIOGRAPHY}

Burgess, J. W. "Political Science and Comparative Constitutional Law," Vol. II, Division II, Chapter III (The Construction of the German Imperial Legislature). Chapter VIII (The Powers of the German Imperial Legislature). Chapter IX (Comparison of the Constitutions of the United States and the German Empire upon the Subject of Legislative Powers).

OGG, F. A. "The Governments of Europe," pp. $223 \mathrm{ff}$. Lowell, A. L. "Government and Parties in Continental Europe," Vol. I, pp. 252 ff.

Howard, B. E. "The German Empire," Chapter V. 


\section{CHAPTER VI}

\section{THE B U N D E S R T}

$7 \mathrm{HE}$ Bundesrat corresponds in its composition

1 to the Plenum of the Bundesversammlung of Its com- the German Confederation. Prussia received in position addition to her original four votes, those of Hanover (4), Electoral Hesse (3), Holstein (3), Nassau (2) and Frankfort-on-the-Main, (I) so that this state now has seventeen votes. To these must be added the three votes of AlsaceLorraine, since the Governor of that provincestate is appointed at the pleasure of the King of Prussia, and the one vote of Waldeck, which by a treaty has given her administration, and with it her vote in the Bundesrat, to Prussia. Bavaria received six votes instead of the four in the German Confederation. This concession had been made to it in the Customs Parliament of 1867-1870, and was taken over into the Constitution of the new Empire.

The rest of the sixty-one votes are distributed among the twenty-six states as follows: Saxony and Würtemberg four votes each, Baden and Hesse three each, Mecklenburg-Schwerin and Brunswick two each, and the remaining seventeen states one vote each. Alsace-Lorraine has three votes. The votes of Alsace-Lorraine are not [64] 
counted, if Prussia by the addition of these votes alone would have a majority, nor in case of a tie, nor in case of amendments to the Constitution.

The chairmanship of the Bundesrat belongs to Prussia. The Chairman is the Chancellor of the Empire. This chairmanship may be delegated by the Chancellor to a Prussian substitute or any other member of the Bundesrat, but by a Organization of the

Bundesrat special treaty with Bavaria (November 23, I870), this state has the privilege of being the first of the other states to be asked to take the chair. Theoretically the Bundesrat is not a permanent body. According to Article 12 of the Constitution, the Kaiser has the right to open, adjourn and close the Bundesrat. But in fact the business of the Bundesrat has become so enormous that for many years it has been in permanent session. It must be convened, whenever a meeting is demanded by one-third of the total number of votes, ${ }^{1}$ also whenever the Reichstag is in session. ${ }^{2}$

Each member of the Federation has the right of appointing as many delegates to the Bundesrat as it has votes, but the votes of each must be cast as a unit. In practice, however, if a state has the right to several delegates, they are usually not all present.

For the detailed investigation of bills the Constitution ${ }^{3}$ provides for eight permanent committees, on

Committees of the Bundes-

1 R. V., Article I4.

${ }^{3}$ R. V., Article 8.

2 R. V., Article 13. rat 


\section{GERMAN GOVERNMENT AND POLITICS}

I. Army and Fortifications.

2. Marine Affairs.

3. Customs Duties and Taxes.

4. Commerce and Trade.

5. Railroads, Posts and Telegraphs.

6. Judicial Affairs.

7. Accounts.

8. Foreign Affairs.

On each of these committees (Ausschüsse), Prussia, and four other states must be represented. At present the Committee on Marine Affairs has five members, while all the others have seven. The states to be represented are selected each year by the Bundesrat, except in the case of the Committees on Army and Fortifications and Marine Affairs, which are appointed by the Kaiser. On the Committee on Army and Fortifications Bavaria, by the Constitution, Würtemberg and Saxony, by treaties, are guaranteed permanent seats. By the Constitution, Bavaria is given the chairmanship of the Committee on Foreign Affairs. The other two kingdoms have permanent seats, and at least two other states must be represented. This committee exercises a supervision over the conduct of foreign relations which are administered for the Empire by Prussia through its Ministry of Foreign Affairs. Before important steps in diplomacy are undertaken the committee is consulted and it may exercise a sort of veto, subject to the decision of the Bundesrat as a whole. Besides these constitutional [66] 


\section{THE BUNDESRAT}

committees there exist four permanent committees (on Alsace-Lorraine, on the Constitution, on order of business, on railroad rates) and several others created temporarily for special purposes. In all committees each state has only one vote. The individual member to sérve on each committee is designated by the state entitled to representation.

The members of the Bundesrat are delegates of their respective states. It is a Staatenhaus and represents the federal principle in the Empire. The delegates are not the peculiar representatives of the princes, as some writers say, but of the states. Their instruction is the internal

The position of the members of the Bundesrat business of each individual state. If, for instance, Baden were transformed into a republic, the Bundesrat would have to accept the instructed delegates of the popular sovereign under the same conditions as it now accepts the delegates of the monarchical sovereign. In fact there are twenty-two delegates instructed by princes and three instructed by the Senates of republics. The members of the Bundesrat are responsible only to their respective states for their conduct in the Bundesrat, and a violation of their duties is punished according to the laws of the jurisdiction in question. The Bundesrat does not therefore investigate the instructions of the different members, but is only concerned with their right to be members. The vote of the delegate is final, a fait accompli. The fact that he may 


\section{GERMAN GOVERNMENT AND POLITICS}

have violated his instructions does not affect the validity of measures passed with his assistance.

The members of the Bundesrat have the position of diplomatic officers and are exempt from the jurisdiciton of Prussian courts. ${ }^{1}$ Each member of the Bundesrat has the right to appear in the Reichstag and "must be heard there at any time he shall so request, in oraier to represent the views of his government, even when such views shall not have been adopted by the majority of the Bundesrat. ${ }^{2}$ " Of this right frequent use is made.

German theory and practice have never sanctioned the "separation of powers" advocated Func- by Montesquieu and accepted in the United
tons of the States. On the contrary, a disconnection of Bundes- legislative and administrative functions has alrat ways been considered detrimental to the harmony and efficiency of government. The Bundesrat, the most important legislative organ of the Empire, has also vast administrative and judicial competence.

As an organ of administration the Bundesrat has an extensive ordinance power. ${ }^{3}$ It is the connecting link between the laws made by the Empire and the execution of these laws by the several states. Article 7, Clause 2, of the Constitution says: "The Bundesrat shall take action upon the general administrative provisions and arrange-

1 R. V., Article 10.

2 R. V., Article 9.

$$
{ }^{3} \text { Cf. p. rro. }
$$

[68] 


\section{THE BUNDESRAT}

ments necessary for the execution of the Imperial laws, so far as no other provision is made by law." Sometimes the law makes a provision giving the ordinance power for its detailed administration to the Kaiser, the Chancellor, a department of the Imperial government or the several states. In all other cases the power is exercised by the Bundesrat. Furthermore, clause three of the same article gives the Bundesrat the power of taking action upon "defects which may be discovered in the execution of Imperial laws" or of their general administative provisions.

Like some other upper houses the Bundesrat has the right to recommend, propose or elect some higher administrative officers. ${ }^{1}$

In order to bring about a certain unity in the administrative system of the Empire, even where a specific matter is left to the several states, it is sometimes discussed in the Bundesrat. Of course these discussions have no binding authority. It cannot be too much emphasized that the delegates of the German state who compose the Bundesrat for making laws and determining matters of administration are the same men who, in their several states, have to do with the enforcement of those laws. The Bundesrat is an assembly of administrators, of leading Ministers from each state. Thoroughly familiar with the administrative needs of the state they embody

1 Cf. Laband, P., p. 62, footnote 3, and R. V., Articles 36 and 56 . 


\section{GERMAN GOVERNMENT AND POLITICS}

them into law, thus giving the Empire the benefit of an experience possessed by no other legislative body in the world. At the same time their presence in the federal legislature goes far to minimize the difficulties which have appeared in other federations where the power of executing federal laws has been left to the states.

As a judicial organ the Bundesrat has the posi-

Judicial powers of the Bundesrat tion of a supreme administrative court. As such the interpretation of the Constitution, so far as provision is made for it at all, is entrusted to the Bundesrat. ${ }^{1}$ Certain special laws explicitly confer upon the Bundesrat the right to render decisions of an administrative law character. ${ }^{2}$ Article 77 of the Constitution gives the Bundesrat the right to force a state to render justice to an individual. The person denied justice must complain to the Bundesrat, which investigates the case and if it finds the complaint justified obtains judicial relief for the complainant from the government in question.

Disputes between several states relating to matters of public law may be adjusted by the Bundesrat, at the request of one of the parties. ${ }^{3}$ The Bundesrat may refer, and several times has referred the matter to a high court or a special expert for definite decision.

${ }^{1}$ See an example of Laband given by J. H. Robinson in his monograph, "The German Bundesrat," p. 63.

2 E.g., the decision as to whether in the interests of traffic the gates of a fortress should be widened and if so by how much. [See Laband (larger edition), Vol. I, p. 247.]

${ }^{3}$ R. V., Article 76, I.

[ 70 ] 
"In disputes relating to constitutional matters in those states of the Union whose constitution does not designate an authority for the settlement of such differences, the Bundesrat shall, at the request of one of the parties, effect an amicable adjustment, and if this cannot be done, the matter shall be settled by Imperial law." 1 The case of Mecklenburg, where the government and legislature have now for years disagreed in regard of Meckto the introduction of a constitution, has made lenburg this paragraph a very interesting and practical one. The conservative Estates are opposed to the introduction of a constitutional government, while the Grand-Dukes of the Mecklenburgs are willing to grant one to the people. No agreement can be reached. The parties of the Left in the Reichstag consider it a disgrace for Germany that two of its states should be the only states in Europe without constitutions. They and their press have therefore often discussed the question of forcing upon the Mecklenburgs a constitution through the Reichstag. But the Bundesrat has always taken the point of view that the German government has no right to interfere in Mecklenburg's affairs according to the article, cited above, unless either the Estates or the Grand-Dukes ask the Bundesrat to do so.

Article 76 does not refer to disputes as to succession or regency in the several states. Such disputes are differences between princes, not

1 R. V., Article 76. 


\section{GERMAN GOVERNMENT AND POLITICS}

between states nor between the government of a state and the representatives of the people. However, indirectly the Bundesrat is a court for the decision of questions of succession and regency, for it has to look into the credentials of every member of the Bundesrat and may therefore refuse to accept the delegate of a ruler whom it does not recognize.

Finally the authorization of "federal execution" in case a state of the Federation does not fulfil its constitutional duty ${ }^{1}$ may be mentioned as a judicial function.

The Bundesrat is the most original institution General of German government. Since it is the repreconclusions sentative body of the monarchs and senates of the several states it might be supposed to be a reactionary or unduly conservative body. This cannot justly be said of it. It is a progressive conservative body. Many times it has surprised the German people by its progressive proposals as the great financial reform of 1909. The Conservatives and Clericals, the majority parties in the Reichstag, are certainly less progressive than the united governments in the Bundesrat.

The Bundesrat represents the federal principle and therefore might be supposed to be the seat of a local patriotism, while the Reichstag, representing the German people, being the outcome of the national German movement should natu1 R. V., Article 19.

[ 72 ] 


\section{THE BUNDESRAT}

rally manifest the national spirit. Just the opposite is true. We never hear of sentimental local pride finding expression in the Bundesrat, although on many important questions the delegates represent the interests of their several states, while all shades of petty particularism are found in the Reichstag. The members of the Bundesrat are statesmen of a high type, experienced in the practical work of government. They are, for the most part, broad and high-minded men, by nature careful and conservative, by experience ready to compromise, not striving for the unattainable, a most efficient governmental body. They do not talk as much as the members of the Reichstag, and they do not need to, since they do not depend on the people and cannot hope to dazzle their constituents with oratory. They are men of action, a body of workers. Thus they enjoy in general the respect of the German people. The Bundesrat stands higher in the regard of the educated class than does the Reichstag.

\section{SELECTED BIBLIOGRAPHY}

Howard, B. E. "The German Empire," Chapter IV

(The Bundesrat).

Robinson, J. H. "The German Bundesrat." OGG, F. A. "The Governments of Europe," pp. $217 \mathrm{ff}$. Lowell, A. L. "Government and Parties in Continental Europe," pp. $259 \mathrm{ff}$. 


\section{CHAPTER VII}

T H E K A I S E R

Draesidium" (Presidency), "Commander in Chief of the Federation," and "Crown of Prussia" were the three terms used in the

Nature of the Kaiser's position

Constitution of the North German Federation to express Prussia's leadership in it. After the conclusion of the November treaties, ${ }^{1}$ the Bundesrat of the North German Federation, with the consent of the southern states, proposed in the Reichstag to give to the King of Prussia the title "German Kaiser." The initiative to this step was taken by the noble and unfortunate King Louis II of Bavaria. In a letter to King William of Prussia, of November 30, 1870, he wrote: "After the accession of South Germany to the constitutional union of Germany, the rights of the Praesidium conferred upon Your Majesty will extend over all the German states. I have given my consent to their union in a single hand, convinced, that to do so corresponds with the interests of the German Fatherland as a whole and of its allied princes, but at the same time confident that the constitutional rights of the Praesidium of the Federation created by the

$$
1 \text { Cf. p. } 22 .
$$

[ 74] 
restoration of a German Empire and of the dignity of a German Kaiser are rights which Your Majesty exercises in the name of the whole German Fatherland, upon the basis of universal consent of her princes. I have therefore proposed to the German princes to suggest with me to Your Majesty that the exercise of the rights of the Praesidium of the Federation should be connected with the title of 'German Kaiser.'" From this letter it can clearly be seen that the title does not carry any power, and that it was meant to be nothing but an honorary title, to express to the world externally the dignity of the new state. In this sense the title was accepted by King William of Prussia. Thus the new redaction of the Constitution, April 16, 1871, replaced the terms of the Constitution of the North German Federation with the name "Kaiser." The legal power of the Praesidium has not only not been increased, it has, in spite of the more dignified title, been decreased, owing to the accession of the southern states and the privileges granted to them.

Only the King of Prussia, not a substitute or a regent, may bear the title Kaiser, although they are likewise endowed with all the Imperial power during the time they may happen to rule in Prussia. Since the Constitution says nothing in regard to the succession to the Praesidium, it is generally recognized that Prussian law alone determines it. 


\section{GERMAN GOVERNMENT AND POLITICS}

The Kaiser does not participate directly in

Fils governmental functions the creation of Imperial laws. His formal duties with regard to legislation will be mentioned later. ${ }^{1}$ As the instructor of Prussia's vote, the Kaiser has a veto on constitutional amendments and changes of Imperial legislation in regard to taxes and customs duties enumerated in R. V., Article $35, \mathbf{I}^{2}$

The Kaiser has the right to convene, open and adjourn the Bundesrat and Reichstag. ${ }^{3}$ His consent is necessary for the dissolution of the Reichstag. ${ }^{4}$ A certain influence over legislation is exercised by the Kaiser through his right to appoint the members of the Bundesrat committees on the army, the navy and the fortresses. ${ }^{5}$

The Kaiser has executive functions of great importance. He is the international representative of the Empire. In the name of the Empire he enters into alliances and treaties with foreign countries, receives and accredits Ambassadors. By the right of appointing and dismissing the Chancellor ${ }^{6}$ and Imperial officials, inclusive of consuls, ${ }^{7}$ he controls the whole Imperial administration which expressly includes the Post and

1 Cf. p. II5.

2 R. V., Article 37. "In taking action upon the rules and regulations for the execution of joint legislation (enumerated in Article 35) the vote of the Praesidium shall decide when it is cast in favor of maintaining the existing rule or regulation."

${ }^{3}$ R. V., Article 12.

4 R. V., Article 24.

6 R. V., Article 8.

6 R. V., Article I5, I.

[ 76 ]

7 R. V., Article 56. 
Telegraph Service." The Kaiser carries out "federal execution" when ordered by the Bundesrat." $\mathrm{He}$ also has the power to declare martial law in any part of Germany if public security demands it. $^{3}$

A tremendous power is vested in the Kaiser as Commander in Chief of the army and navy, in peace as well as in war. The limitations of this power through Bavaria and Würtemberg have been already described.

While all these powers are constitutional, and therefore original, two executive functions are delegated to the Kaiser by special laws.

The law concerning the Constitution of AlsaceLorraine makes the Kaiser the governmental authority in that province. As such he appoints and removes the Governor and by doing this controls the votes of that province in the Bundesrat. Furthermore, he has an absolute veto on the legislation of Alsace-Lorraine.

The "Law in regard to the Legal Status of the German Protectorates" (Gesetz betreffend die Rechtsverhältnisse der deutschen Schutzgebiete) of April 17, 1886, delegates to the Kaiser governmental authority in the German protectorates.

The pardoning power does not belong to the Kaiser, as a constitutional right, but has been delegated to him by special laws. ${ }^{4}$

1 R. V., Article 50.

2 R. V., Article 19.

3 R. V., Article I I.

4 See Arndt, A., "Das Staatsrecht des deutschen Reiches," pp. $84 \mathrm{ff}$. 


\section{GERMAN GOVERNMENT AND POLITICS}

The Kaiser is not responsible for his public

His personal privileges or private acts. The Chancellor, by countersigning his public acts (R. V., Article 17) assumes the responsibility for them. This principle is generally accepted. The person of the Kaiser is more sacred than that of private citizens. Offenses against him (crimina laesae majestatis) are therefore punished more severely than those against private citizens. ${ }^{1}$

The more serious criminal acts are punished with imprisonment for life and the less dangerous cases with imprisonment for five years. ${ }^{2}$ Assassination or any attempt at it is punished by death. ${ }^{3}$

Other personal privileges connected with the title of German Kaiser, are:

I. The right to have an Imperial crown, Imperial arms, and an Imperial flag.

2. To decide by ordinance, the title, rank and uniform of the officers of the Imperial civil service.

3. To have the word "Imperial" used in connection with his private officers and servants.

4. To have his son called "Crown Prince of the German Empire and of Prussia."

No financial remuneration is connected with the title "Kaiser," but he receives through the Budget a certain sum, the Dispositionsfond for purposes of representation.

1 Penal Code of the German Empire $\$ 95$.

2 Ibid $\S 94$.

${ }^{3}$ Ibid. \& 80.

[78] 


\section{THE KAISER}

The foregoing enumeration of the powers of the Kaiser shows that he may be an important factor in German government, if he takes full advantage of the powers vested in him. Although, from the standpoint of constitutional law, we must make a clear distinction between the position of the Kaiser and that of the King of Prussia, politically they are inseparable. What he cannot do as Kaiser, he may do as chief of the most powerful state in the Union. From the point of view of practical politics, it makes no difference in which capacity he may at a given moment be acting. It can also easily be seen that if he does not exercise his power, the Chancellor, the only Minister of the Empire, who may combine with this position that of President of the Prussian Council of Ministers, will exercise it for him. Who is, at a given moment, the real ruler of Germany depends on the personality of Kaiser and Chancellor.

William I, the first Kaiser, was born March 22, 1797, the second son of Frederick William Willam I III, at that time still Crown Prince of Prussia, and the noble Princess Louisa of MecklenburgStrelitz. His childhood fell in the saddest time of Germany, its subjection to the tyranny of Napoleon I. As a boy of sixteen he received his commission as captain and joined the headquarters of the allied monarchs at Frankfort-on-the-Main as aide-de-camp of his father. Later on he accompanied Blücher's army to France and was

The three German Kaisers as real factors of German government 


\section{GERMAN GOVERNMENT AND POLITICS}

His confesslon

several times under fire. In the year $181_{5}$, the prince was confirmed, and it was then that according to a Hohenzollern custom he wrote down his confession of faith or as he called it Lebensgrundsätze. ${ }^{1}$ These lines are significant of the motives which characterized his whole life as Prince, King, and Kaiser. To quote a few phrases: "I rejoice in this station, not on account of the distinction it confers upon me, amongst men, nor on account of the enjoyments it places at my disposal, but because it enables me to achieve more than others. My princely rank shall always serve to remind me of the greater obligations it imposes upon me, of the greater efforts it requires me to make, and of the greater temptations to which it exposes me. I will submit myself to God, in the firm conviction that He will always do what is best for me. My capacities belong to the World and to my Country. I will therefore work without ceasing in the sphere of activity presented to me, make the best use of my time, and do as much good as it may be in my power to do. I will not domineer over anybody in virtue of my rank, nor make an oppressive use of my princely position.

"To the utmost of my ability, I will be a helper and advocate of those unfortunates who may seek my aid, or whose mishaps I may be informed of - especially of widows, orphans, aged people, men

1 Given in full by Forbes, "William of Germany,"

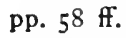

[8o] 


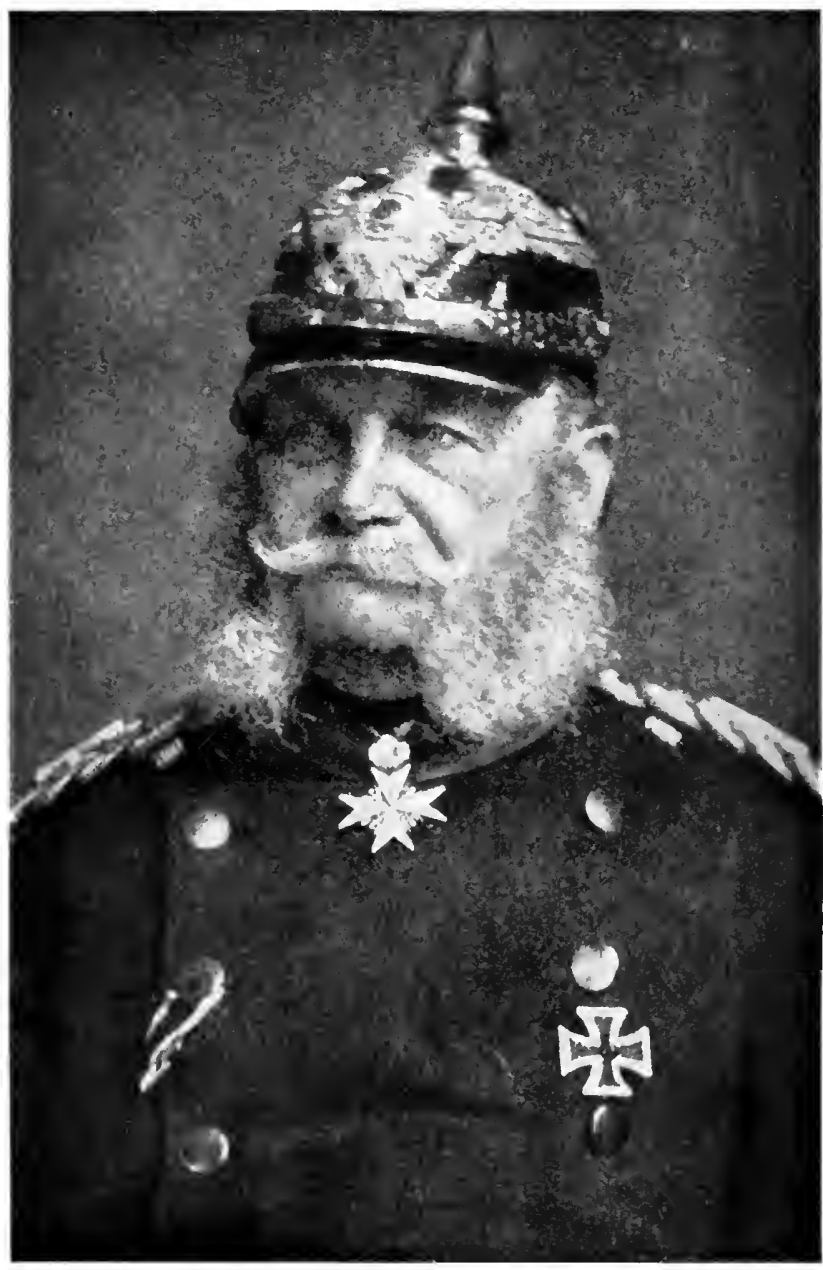

WIILI.A.M I

First Kaiser of Germany 

who have faithfully served the state, and those whom such men may have left behind them in poverty. ${ }^{1}$ Never will I forget good done to me by my fellow-men. ${ }^{2}$ I will perform all my service-duties with absolute exactitude, and while assiduously keeping my subordinates to their duty, will treat them amicably and kindly."

It is indeed highly surprising to what a great extent the Prince attained his ideal. These words were no empty phrases; his life proved their sincerity. During the time which followed, until he became Regent in 1857 , Prince William devoted himself with all his heart to the military service. In October, $185^{8}$, he became permanent Regent and after the death of his brother in January, I86r, King of Prussia.

As a soldier, William had seen the great defects of the Prussian army. He knew that the "Shame of Olmütz" would not have humiliated Prussia, if she had been a strong military power. To avoid the recurrence of such a diplomatic defeat and to prepare his country to meet any Prusslan Army reorganization under King Wil$\operatorname{llam} I$ enemy, William held the reorganization of the army to be the most necessary step in Prussian government. He emphatically pointed out its necessity in his speech at the opening of the Prussian Parliament. But the Liberal majority in the Lower Chamber, fearing that they might

1 See how much he has done at the end of his life for these people through initiating Germany's social legislation.

2 What a friend he was to Bismarck! 


\section{GERMAN GOVERNMENT AND POLITICS}

make the Crown too independent and lose control of it, persistently refused to vote for the expenditures made necessary by military reconstruction. Three courses were open to the King: The first, to give up the reorganization, was impossible for him. He would sooner have abdicated. So he had either by a coup d'état to abolish the constitution or find a strong man, who would carry out his will in spite of the opposition of Parliament. Happily he found this man in Otto von Bismarck, who was appointed Minister-President in September, 1862, with Roon as Minister of War. In I 858, Helmut von Moltke had been made Chief of the General Staff of the army. These three men together with the King led Prussia to its victories in war and diplomacy, as a result of which the German Empire arose. ${ }^{1}$

As a Prince, disliked, even hated by the masses, he was at the end of his life in 1888 , beloved by his people as seldom a ruler has been. His kindness of heart, even towards the humblest servant, could not be excelled. He was a soldier from top to bottom, possessing all the virtues of that class: a high sense of duty, courage, exactness in the smallest details, activity. Like his great ancestor, Frederick II, he regarded himself as the first servant of his country. Significant are his words when asked at the end of his life to stop work for a while on account of his weakness: "I have not time to rest." The German people have

${ }^{1}$ See the continuation of this historical part on p. $17 \mathrm{ff}$. [82] 
given him the name "the Great." This title, however, must not be interpreted in the same sense as the "Great" of Frederic II; for William I was not a genius. The tremendous success of his reign without hesitation, must be attributed to his Chancellor Bismarck. Very little was done except on the initiative of the Chancellor and nothing of importance without his consent. Bismarck created the chancellorship to fit his own gigantic proportions. William I was King and Kaiser, but Bismarck governed. No love, nor highest esteem for the old Kaiser can change this fact. However, he was great in that he recognized the genius of Bismarck and in spite of all open opposition and secret effort to undermine his confidence trusted him throughout his life.

William I was succeeded by his only son, Frederick III. He was born October I8, I83I. Like all the princes of the House of Hohenzollern, he became a soldier. In the winters of 1850 and 185 I he attended the University of Bonn, the first of the Hohenzollern princes to take up academic studies. His fields of study were mainly history, law, politics and French and English conversation. In the winter of $1855-56$ he was made acquainted with the inside working of the different ministerial departments, and, as he expressed himself to his future father-in-law, the Prince Consort Albert of Great Britain, ${ }^{1}$ he was dis-

1 See: M. von Poschinger, "Life of the Emperor Frederic," p. 67 . 


\section{GERMAN GOVERNMENT AND POLITICS}

gusted with the unjust and reactionary government of the Manteuffel ministry. In 1858 he married Victoria daughter of the Prince Consort and Queen Victoria of Great Britain. When Bismarck took the reins his unconstitutional government naturally met with the disapproval of the liberal minded Crown Prince. Undoubtedly he was carried too far by this sincere sentiment. In his hostility to Bismarck's policies he went so far as to call him a "most dangerous adviser for Crown and country." 1

During the war with Denmark, 1864, the Crown Prince was attached to the staff of the old Field-Marshall Wrangel, whom he had to supervise. He did it with great tact and showed at the same time his ability as a general. Misunderstanding entirely Bismarck's policy for Germany's unity, he opposed the war with Austria. In that war he commanded one of the three armies and decided the battle of Königgrätz, and thereby the war. After it, the Crown Prince, with the right wing of the Liberal Party, became convinced of Bismarck's high patriotism and his ability to conduct the foreign affairs of the Empire. In their fundamental conceptions of internal policy, however, they could never agree.

The Franco-German War found the Prince commanding the Third Army composed of troops from the southern states. In this position he

1 See M. von Poschinger, "Life of the Emperor Frederic," p. 149 .

[84] 
gained the highest reputation as a general and an enormous popularity as soldier and man. $\mathrm{He}$ was not able to exert great influence in internal politics, since he did not agree with Bismarck, who was upheld by the Kaiser.

The field in which he was especially interested was social reform. As $M$. von Poschinger in her biography of Frederick, says (pp. 355-356): "In Fis Interest in social reaccordance with his idealistic tendencies he regarded the modification of class distinctions, recognition of intellectual claims, personal 'rapprochement' of employers and employed, and kindly intercourse between men, as the chief means of compensation for the inevitable hardships of industrial life. Freedom from economic distress would, he hoped, result from the spiritual liberty and elevation of the nation. He became in course of time, the center and initiator of all charitable efforts in the country."

From June 4 to December 5, I878, the Crown Prince was commissioned with the regentship because of the serious condition of his father resulting from an attempt upon his life made by the fanatic socialist Hödel. He followed the wishes of the Kaiser in carrying on the government according to Bismarck's principles. We cannot, therefore, consider this period of government as characteristic of what his future reign might have been.

In the beginning of 1887 a terrible disease, cancer of the throat, began to develop from which 


\section{GERMAN GOVERNMENT AND POLITICS}

the Prince suffered severely up to the end of his life, June 7, I888. He therefore could do very little during the ninety-nine days of his rule. One affair, however, during this time deserves especially to be reported, because it shows the constitutional conscientiousness of the Kaiser; the dismissal of von Puttkammer, Minister of the Interior. The main reason for it was the attempt of this friend of Bismarck to influence the elections, while Frederick demanded that "the liberty of future elections should not be restricted by official pressure."

With Kaiser Frederick III died the hope of the Hls liber- liberal educated class of Germany. During his
alsm whole life, while not a political liberal he had been the champion of free thought and tolerance. Audiatur et altera pars (Let the other side also be heard) was his fundamental principle. Justice to every opinion of a serious minded man could be expected from him. From his firm attitude towards Bismarck before 1866 , and his insistence on the dismissal of Puttkammer, we may draw the conclusion that he would have been a factor in the German government had destiny given him more time. Although by nature liberal minded, he had a very strong historic sense, and had expressed himself against the introduction of the responsible ministerial form of government. ${ }^{1}$ With the radical liberal parties he disagreed entirely in his ideas on the army and navy. These were for him the

$$
1 \text { Cf. p. } 40 .
$$

[86] 


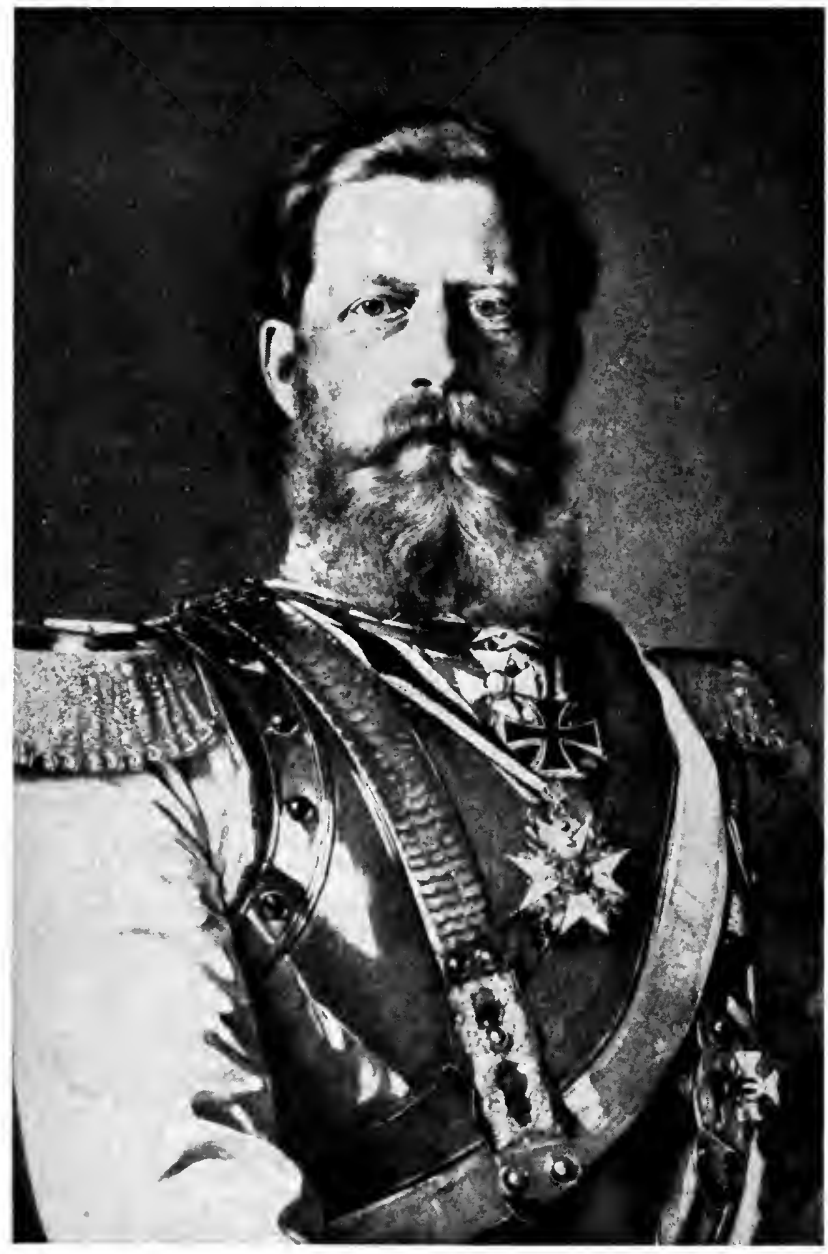

FREDERICK III

Second Kaiser of Germany 

strong instruments of the Crown, over which it alone had control. ${ }^{1}$ What the relation between Frederick and Bismarck would have become under different circumstances we may well fancy. They were independent men of different fundamental principles which fact might well have led to a rupture.

While Frederick III became famous and attracted the attention of his people as Crown William II Prince, comparatively little was known about William II when he ascended the throne at the early age of twenty-nine. An anonymous writer in a sensational French book, ${ }^{2}$ first called the attention of the world to this talented man. This writer must have known him very well or else received his information from a keen observer. He writes about him as follows: He is "courageous, enterprising, ambitious, hot-headed, but with a heart of gold, sympathetic in the highest degree, impulsive, spirited, vivacious in character, and gifted with a talent for repartee in conversation which would almost make the listener doubt his being a German. He adores the army, by which he is idolized in return. He is highly educated, and well read. He certainly will be a distinguished man, and very probably a great sovereign. He will be essentially a personal king, never allowing himself to be blindly led and ruling with

1 See, M. von Poschinger's Biography, p. 398.

2 "Société de Berlin." Par le Comte Paul Vasili. Paris 1883. 


\section{GERMAN GOVERNMENT AND POLITICS}

sound and direct judgment, prompt decision, energy in action, and an unbending will."

The Prince was the first Hohenzollern to attend a public gymnasium, and live in the company of its ordinary pupils. A lasting influence upon the boy during his years at the gymnasium at Cassel was exercised by his tutor, Dr. Hinzpeter, to whom is ascribed the friendly attitude of the future Kaiser towards social reform and his difference of opinion with Bismarck in regard to the Social-Democrats. After graduation, William entered the University of Bonn at the age of eighteen. At the same time he began his military service as a lieutenant of the Guards. Now his environment changed entirely. He came mainly under conservative and reactionary influence and soon joined the party of his grandfather and Bismarck in silent opposition to the liberal views of his father.

Willam II When the young Kaiser took the reins of and the peace of the world government into his hands, the eyes of all Europe were directed upon him in nervous excitement. Very little was known about him, and the stories told about his character and views made him a reactionary, brutal warrior. $\mathrm{He}$ certainly has surprised the world in many regards.

Year after year passed. All the great powers of Europe, Asia and America became involved in wars except Austria-Hungary, France, whose ambition is the conquest of an African colonial empire, and Germany. The title "War Lord"

[88] 
began to be replaced by that of "Peace Lord." 1 Judged by results, no monarch deserves the title so well as he. It is true, the army and even more the navy have been increased enormously during the reign of the present Kaiser. He was the strongest advocate of this increase, but there can be no doubt that the war preparedness of Germany, emulated as it has been by other nations, has had a quieting effect upon the contentions of European powers. Not only in this sense but by calm counsels at moments of national hot-blood has the Kaiser often helped to keep the peace of Europe.

Like most of his ancestors, the Kaiser is a soldier with his whole heart. He loves his army and has an interest in it which is only surpassed by Willam II and the army his interest in the navy. His intimate knowledge of the most detailed questions of army and navy is said to be nearly incredible. Reforms are constantly being introduced at his initiative. For example, his letter of February 15, 1890, to the Minister of War, may be cited. He said: "In my army every soldier is to be treated according to law, justly and humanely. Only thus is it possible to inspire him with zeal and devotion to duty and love and respect for his superiors." In a Cabinet ordinance of March 2, I890, the Kaiser

1 See Fried, A. H., "The German Emperor and the Peace of the World." New York, rgr2. A book in which he describes the Kaiser as a promoter of peace, and for which he received the Nobel Peace Prize. 


\section{GERMAN GOVERNMENT AND POLITICS}

said: "Nobility of birth alone cannot to-day, as formerly, exclusively entitle to the prerogative of furnishing the officers for my army. Nobility of character, which has at all times distinguished our officers must be, now more than ever, insisted upon in such appointments. I strongly disapprove the idea that any officer in my army is to be estimated according to the size of the allowance guaranteed him from home. On the contrary, I rank in my mind the highest those regiments whose officers know how to do their full duty, joyously and with alacrity, and who nevertheless receive but modest allowances from their families. The growing luxury must be opposed seriously and persistently." A sensational Cabinet ordinance was issued by the Kaiser, January 1, 1897, in which he advocated the greatest possible restriction of duelling among officers, a courageous step indeed, which unfortunately has had less success than expected. ${ }^{1}$

HIs interest in the navy

The navy, however, is the most beloved child of the Kaiser. When he ascended the throne it hardly existed, and it has been his keen interest and urgent insistence which have created and developed a first-class navy in Germany. His systematic persistent campaign in its behalf aroused the slow German mind, so that now ardent interest in a strong navy is taken by every

${ }^{1}$ See von Schierbrand, "The Kaiser's Speeches," p. 169. All quotations from the Kaiser's speeches are taken from this book.

[ 90 ] 


\section{THE KAISER}

patriotic German. The creation of the navy alone would make William one of the leading figures in German history.

While the army and navy are the present Kaiser's most favored fields, it can be said that he is interested in everything. He talks in public on countless subjects, - on theology, the latest excavations in Assyria, airships and aeroplanes, economics, education, painting, sculpture, music and many other things beside.

$\mathrm{He}$ is a peculiar mixture of progressive and The reactionary ideas. No man can take a keener interest in the modern development of industry, commerce and navigation. He grasps every new idea and seeks first-hand information upon it.

He makes the barons of industry and commerce his special friends. In pedagogy he emphasizes the value of practical education. $\mathrm{He}$ admires the great conqueror of the air, Count Zeppelin. $\mathrm{He}$ travels more than any other monarch and tries to get acquainted, not only with princes and aristocrats, but with the leading men of all nations. Again and again he has insisted that efficiency is the first requisite in filling a position rather than nobility of birth, which raises no person in his eyes.

Yet in striking contrast to these advanced ideas he clings to the old doctrine of "Monarchy by the Grace of God," considering himself a divine instrument, irresponsible to the people. Thus he said in Königsberg in 1910: "It was in 


\section{GERMAN GOVERNMENT AND POLITICS}

this spot that my grandfather in his own right placed the Crown upon his head, insisting once again that it was bestowed upon him by the grace of God alone, and not by parliaments and meetings and decisions of the people. He thus regarded himself as the chosen instrument of heaven, and as such carried out his duties as a ruler and lord. I consider myself such an instrument of heaven, and shall go my way without regard to the view and opinions of the day." As long as the Kaiser rules within the limits set for him by the Constitution the Germans are willing to let him enjoy his dogma of "Kingdom by the Grace of God." They know that his interpretation of it means for him the highest responsibility, for he is through and through a religious and conscientious man.

There is one dangerous fault of his character, pulsim- his natural impulsiveness. It has been more ness than once detrimental to German policy. Thus his former Chancellor Hohenlohe complains in his Memoirs (Vol. II, p. 487): "It is not to be denied that the Kaiser disturbs things by his impulsive nature. It is to be wished that he were more phlegmatic." On two occasions especially his indiscretion has done great damage to German diplomacy: The cablegram The of the Kaiser on June 3, I896, to President Kruger and of South Africa, congratulating him upon the

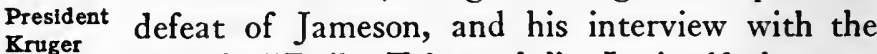
English "Daily Telegraph." In itself the con[92 ] 
demnation of the Jameson raid as piracy was sound, and the whole world agreed with it. But the Kaiser is not a private citizen, and his telegram created very bitter feeling in England and helped to arouse hostility against Germany.

October 28, 1908, the London "Daily Telegraph" published an interview with the Kaiser. In this interview the Kaiser deplored the bad relations between the English and German people. He showed that although Germany needed a strong navy, it was not a menace to England. Furthermore, he said, that "while the prevailing sentiment among large sections of the middle and lower classes of his own people is not friendly to England" the sympathies of the German Government had been on the side of the English in the Boer War. He even declared that he had sent to Windsor a plan of campaign against the Boers, revised by the General Staff of the German Army, which "ran very much on the same lines as that which was adopted by Lord Roberts." The whole interview was as indiscreet as it could be, creating bitter feeling especially in France, Russia and Japan. England simply ridiculed it and became more hostile to Germany than ever. It could hardly be believed that a man as intelligent as the Kaiser could have done such a thing. Prince Bülow was also to blame. $\mathrm{He}$ was spending his vacation at a summer resort and the unprinted interview of the Kaiser had been passed by him without careful scrutiny. Prince Bülow 


\section{GERMAN GOVERNMENT AND POLITICS}

handed his resignation to the Kaiser who, however, did not accept it.

The publication of the interview aroused a tremendous storm of indignation in Germany. The papers of all parties from the most conservative to the most radical criticized the Kaiser severely. The Berlin people did not show their usual enthusiasm when he appeared in public, sometimes punishing him with absolute silence. Only after the Kaiser had confessed his mistake through the Chancellor did he regain the confidence and love of his people. He has since been more careful in his speeches.

On the whole the Kaiser is very popular in

The Kalser's Germany. The people know that he works popularity harder than any other man in the Empire, that he is sincere, and that he always has the best intentions. His personality must be charming and fascinating if we are to judge by the reports of those who know him well. One cannot say that Germany is well liked, but the Kaiser was before the present European war highly regarded in foreign countries, even generally speaking, in England. ${ }^{1}$

${ }^{1}$ Says an English writer who is a Germanophobe through and through: "William II is, perhaps, the most picturesque and the most talked about figure on the stage of the world, and if a computation should be made, it would very likely be found that more columns of the international press are daily filled with accounts of his doings and sayings than with those of all other sovereigns taken together." Barker, J.E., "Modern Germany," p. 66.

[ 94 ] 


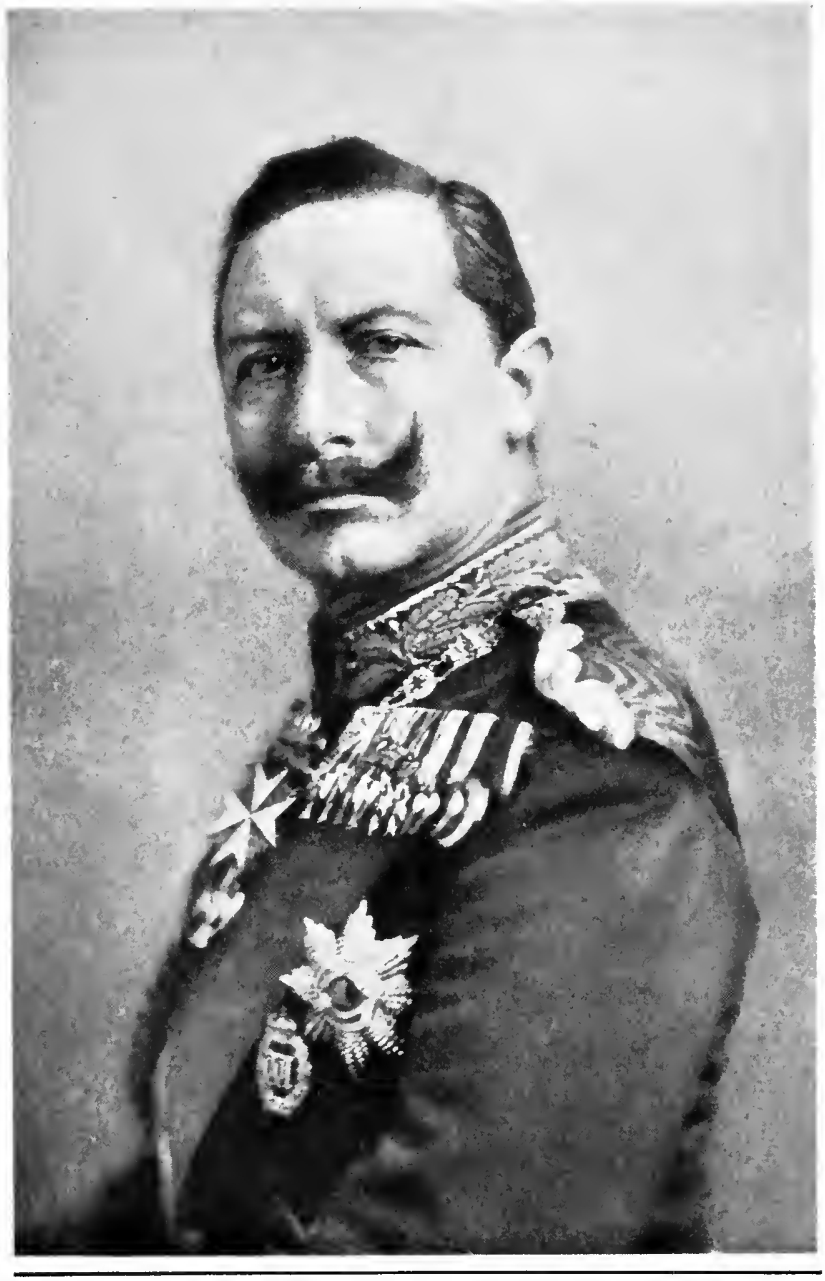

WILLIAM II

Third Kaiser of Germany 



\section{THE KAISER}

As to his position in the government of Germany we must say that he undoubtedly is its most and important factor. Bismarck said of him as a young Prince: "In him there is something of Frederick the Great and he also is capable of becoming as despotic as Frederick the Great. What a blessing that we have a constitutional government." Bismarck likewise prophesied his own end saying that the Kaiser would be his own Chancellor. It was impossible for two such strong personalities to rule together. One had to resign and the Kaiser, having the constitutional right to do so, forced Bismarck's resignation.

The final causes of the rupture were three in number: first, a difference of opinion in regard to the treatment of the Social-Democrats; ${ }^{1}$ second, the question of the Cabinet Ordinance of September 8, I852; ${ }^{2}$ third, a difference of opinion in regard to the relation of Germany and Russia. Just at this juncture came the new

1 Bismarck wanted to suppress the Social-Democrats by "exception-laws," while the Kaiser, probably under the influence of Hinzpeter's teachings, desired to win them to his side by social reforms.

2 This ordinance forbade the individual Prussian Ministers to communicate with the King without the knowledge of the Prime Minister, thus giving the Prime Minister a certain amount of necessary control. The Kaiser wished to revoke the ordinance, because he desired to control the Ministers directly. Bismarck was opposed to such a change and with him stood the whole Ministry. Bismarck's dismissal did not secure its revocation because it is an absolutely necessary regulation. 


\section{GERMAN GOVERNMENT AND POLITICS}

elections which created in the Reichstag a strong opposition to Bismarck. The alternative was, either oppose the Reichstag and if necessary dissolve it, or sacrifice Bismarck. Bismarck was sacrificed and the Kaiser has since always appointed Chancellors who were more or less willing to carry out his own personal policies. The Chancellors, as a whole, have been his tools.

Summing up the importance of William II in the life and government of Germany we must agree with Mr. Price Collier, who says: "Here is a man, who in a quarter of a century has so grown into the life of a nation, that when you touch it anywhere, you touch him, and when you think of it from any angle of thought, or describe it from any point of view, you find yourself including him." 1

\section{SELECTED BIBLIOGRAPHY}

Howard, B. E. "The German Empire," Chapter III. ZoRn, Ph. "The Constitutional Position of the German Emperor."

Simon, E. "The Emperor William I and his Reign." Poschinger, M. von. "Life of the Emperor Frederic." Perris, H. "Germany and the German Emperor," Chapter VIII (Frederic III and William II). Shaw, S. "Wilhelm II."

BARKer, J. E. "Modern Germany," Chapter XVI (The German Emperor as a Political Factor).

1 Price Collier, "The Indiscreet." In Scribner's Magazine, November, 1912. 


\section{CHAPTER VIII}

THE CHA NCELLOR A N D H IS

S U B S T I T U T E S

7 HE only official of the Empire provided for in the Constitution is the Chancellor. ${ }^{1} \mathrm{He}$ is the supreme officer of the Empire, not simply the most important member of a cabinet, like the Prussian Prime Minister, which position he usually also holds. There is no Imperial cabinet.

Constitutional position of the ChanThe system of official organization is bureaucratic or centralized.

The Chancellor has a twofold position, i.e., chairman of the Bundesrat and head of the Imperial administration. His position as member of the Bundesrat has been treated before. ${ }^{2}$ As head of the Imperial administration he assumes responsibility for the decrees and ordinances of the Kaiser by adding to them his countersignature. $^{3}$ The sovereign body of the Empire, the Bundesrat, has nothing to do with the appointment and removal of the Chancellor; he is responsible to the Kaiser, and to him alone. If the Chancellor is not in harmony with the policy of the Kaiser, he must resign. The responsibility of the Chancellor extends to the whole administration, though

1 R. V., Article I5. ${ }^{2}$ Cf. p. 65.

3 R. V., Article 17. 


\section{GERMAN GOVERNMENT AND POLITICS}

none of course expects the Chancellor to be cognizant of all the smallest details of the administration. Bismarck said in the Reichstag December 1, 1874: "It would be an arrogant assertion, if I tried to make believe that I were in the condition to inspect and actively and personally perform or even merely judge with certainty all the details of the wide circle of business for which I assume the responsibility. According to my opinion, the responsibility cannot be expected of the Chancellor in the sense that each individual action within the whole district, for which he is held responsible, is regarded as originating from him personally and consented to by him. ..."

The Chancellor's responsibility is modified with regard to judicial and certain financial officers, who are independent and can be removed only for legal reasons. Whether the Chancellor's responsibility is political, moral or constitutional, is not fixed by the Constitution nor by statute, and opinions concerning it differ. The legal duty of the Chancellor to give an account to the Reichstag of the activities for which he is responsible is generally recognized.

Bismarck was Chancellor till March 20, 1890.

The Chancellors since 1871 His policy, which led to the founding of the German Empire, has been described in the second chapter. Here we shall attempt to give a general picture of his personality, and his importance in the government of the new Empire.

[98 ] 
Bismarck was, in the first place, the greatest master of diplomacy Germany has ever possessed. He did not belong to the old school of petty intrigues, insincerity, and little schemes, but whenever secrecy was not absolutely required, he used a surprising frankness which stupefied his opponents, because of its very novelty. His policy was generally to reach his end by the mathematical rule that a straight line is the shortest distance between two points. With the help of the army he won the hegemony in Germany for Prussia. He prepared the field of European diplomacy carefully in advance for the war with France. His clever leniency towards Austria in I866, against the strongest opposition of his King, reconciled that natural ally of Germany with the new status of affairs and made possible a close union between the two countries. The position of Germany in international politics under his leadership was unquestionably dominant. His greatest moral diplomatic triumph was the adjustment of the differences between Russia and England at the Congress of Berlin.

Undisputed as is his supreme position in foreign affairs, opinions differ about the wisdom of his internal politics. Bismarck certainly was not altogether successful in this field. Once he fought too powerful an enemy, the Clericals; and in the case of the Social-Democrats, he did not understand the real problem. Bismarck was a bitter enemy of responsible ministerial 


\section{GERMAN GOVERNMENT AND POLITICS}

government. He always refused to be classed as a party man and whenever a party was opposed to his views he tried his best to destroy it absolutely. The best example of this kind is his breach with the National Liberal party which had faithfully helped him build up the new Empire. In 1884 he declared in the Reichstag: "The majority of the Reichstag does not make any impression on me. ... Each one of the parties has been in opposition to me; and I have offered my hand to every party, if I have found that it agreed with what I consider to be in the interest of the country, the nation, the Kaiser and the King."

Bismarck has often been accused of having had no principles, because he changed his point of view so frequently, especially in regard to the tariff and the Clericals. It is true he did not believe in principles as something which could never be changed. He was not a theorist of the liberal type, but a practical statesman, who made his policy according to existing circumstances, getting the best out of an unfortunate situation, always ready to compromise to make the government work. When he saw that he had to count with the Clericals as an important factor in the parliament he made peace with them with as few concessions as possible. He changed his point of view in regard to free trade, because economic and political conditions had changed, and free trade or protection was for him not professional [ 100 ] 


\section{CHANCELLOR AND HIS SUBSTITUTES}

doctrine, but a question of opportunism. Bismarck always looked down with contempt on the idealistic dreamers, the doctrinaires in politics, a type which he found exemplified in the Liberal party.

The greatest impulse to Bismarck's work was his high patriotism, and his deference to the crown, which however had nothing of the attitude of a courtier. For him the most important point in the government was the monarchy. Again and again he emphasized in his speeches in the Prussian Chamber and in the Reichstag the monarchical principle, fighting successfully against the least diminution of the constitutional position of his master. ${ }^{1}$

It is known that Bismarck, like many great personalities, hated the press, because in the main it had fought against him most bitterly in the first years of his ministry and because with little knowledge of the facts it often attacked his best meant policies of later days. $\mathrm{He}$ did not see that in a time of growing democracy, in which public opinion is a most important factor, it was the part of wisdom to be on good terms with the leading journalists.

1 See his speech in the Reichstag, January 24, 1882. "The King governs; the Ministers do not. Have I not fought since 1862 ? Have I not protected the royal principle, not only with my body but also with my mind? What makes me stay in this position, if it is not the feeling of fidelity in service and of representing the King and his rights? There is not much pleasure in it...." 


\section{GERMAN GOVERNMENT AND POLITICS}

The severest criticism that can be raised against Bismarck is that he created the Chancellorship to suit his own powerful personality, and satisfy his own ambitions. He did not consider that the government of Germany would ever have to suffer from the impossibility of finding ordinarily a man big enough for the Chancellorship.

Naturally Bismarck was not altogether popular during the time of his service. Like many great men, he came into the world to bring not peace but the sword. He was a man of iron will, great in hate, autocratic in the confidence of his superior personality and his superior mind, full of passion. He was no party man but a colossal individualist, a genius, with Luther the greatest man of active genius Germany has produced. The time has come when a general appreciation of the genius of this great hero supercedes all petty criticisms. Young Germany is united in adoring him as the greatest statesman of Germany, the master of German nationalism.

When the young Kaiser William II had disGeorge missed Bismarck, he looked around for a man of Leo, Count ability who at the same time would be a willing Capriv1 1 instrument of his wishes. He found this person in Count Caprivi, a thorough soldier. He had entered the army in 1849 . In 1866 he had been promoted to a position in the general staff of the army and had been chief of the general staff

1 Born February 24, 1831, died February 6, 1899. Chancellor from March 30, 1890, to October 26, 1894 .

[ 102 ] 


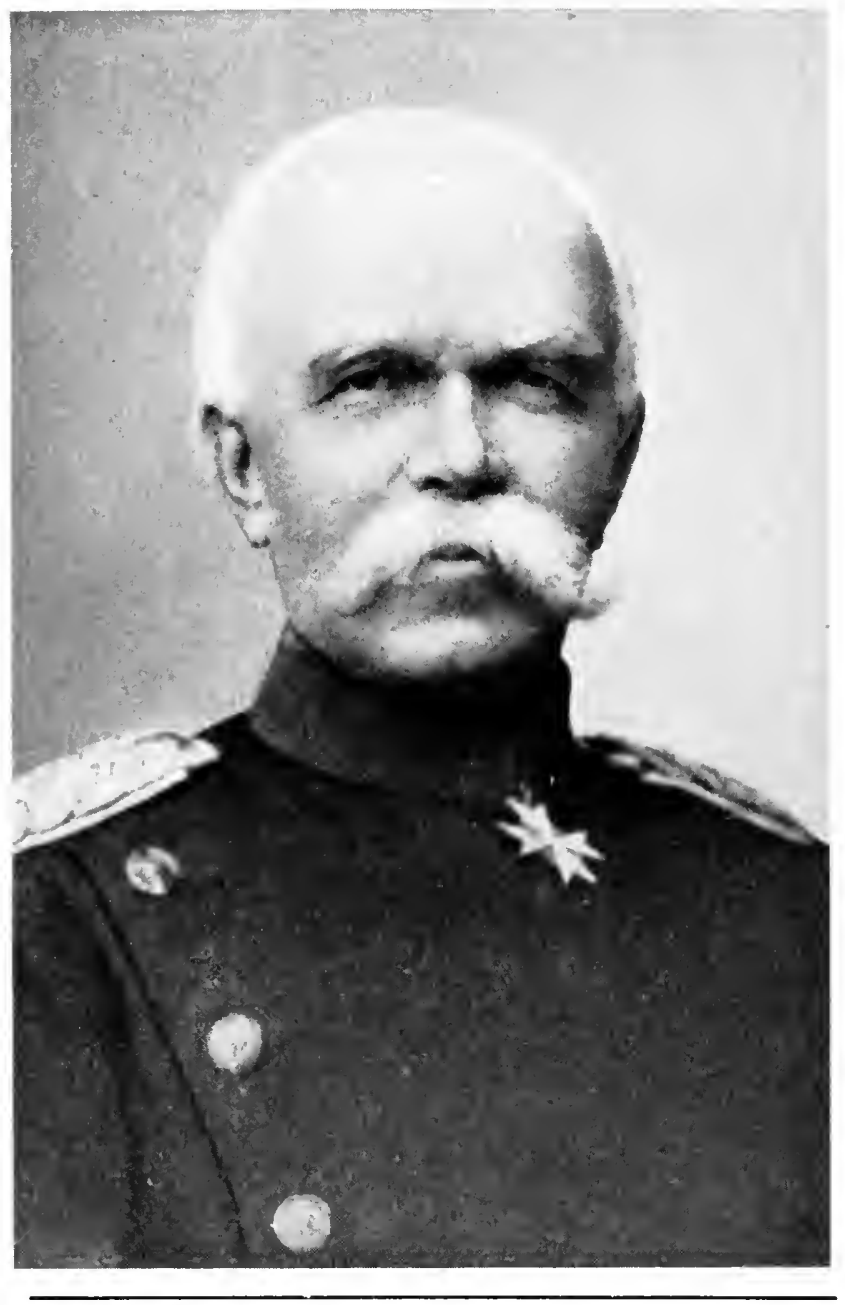

\section{COUNT CAPRIVI}

Second Cbancellor of the German Empire 

of the tenth army-corps during the Franco-German War. From 1883 to 1888 he had managed the navy as vice-admiral. In 1888 he became the general of the tenth army-corps. He accepted the position of Chancellor like an obedient soldier, and carried out the commands of his superior in the same spirit of obedience. Of all the Chancellors he was the least independent. His foreign policy was extremely weak and indefinite. In the Reichstag he was neither loved nor hated. His speeches were not brilliant, but based on a good knowledge of facts. He was entirely lacking in initiative, which he left to the Kaiser. The best accomplishments of his policy were the prolonging of the Triple Alliance, the acquisition of Heligoland, the reform of the army, in which field he was thoroughly competent, and the conclusion of commercial treaties with Austria-Hungary, Russia, Roumania and Italy. The duties on corn were lowered, while German exports were in return favored. This policy aroused the strong opposition of the Agrarians and led to the formation of the "Farmers' Union." The opposition finally grew so strong that Caprivi felt he could not stay in office longer, and so he resigned.

He was succeeded by Prince Hohenlohe-Schillingsfürst. In 1842 , he had entered the Prussian civil service, but resigned in order to take up the management of his estates, Ratibor and Koroci. As Duke of Ratibor he had a seat in the

Chlodwig Karl Victor, Prince zu Hohenlohe- 


\section{GERMAN GOVERNMENT AND POLITICS}

Schll- Bavarian Upper House, the Reichsrat. Here he lingsfurst,

Prince

von

Ratibor

und represented a national German, but anti-Prussian view. In 1849 he was sent to London as Ambassador of the Confederation. In 1866 he changed Koroc: ' his views and advocated in Bavaria a union with Prussia. December 31, I866, he was made Bavarian Prime Minister and worked for a federation of the southern states with the North German Federation. Although a Catholic, he was not a Clerical, and was opposed to the pretentions of the Pope as a superior over all princes and Nations in regard to temporal matters. $\mathrm{He}$ was elected a member of the first German Reichstag and became its first Vice-President. From I 874 to 1885 he was Ambassador at Paris, and from I 885 to 1894 Governor of Alsace-Lorraine. Hohenlohe was too old, when he received the position of Chancellor of the Empire, to undertake anything radical. He had shown himself throughout his life to be clever, unselfish and patriotic. The fact that he was related to the Kaiser made him by nature less dependent than Caprivi, but on the whole his policy was, under the influence of the Kaiser, indefinite and experimental. A strong leader would have made his mark during this period of Germany's rise to world power. In his foreign policy Hohenlohe tried to return to Bismarck's principles.

Prince Bülow, his successor, served in the

1 Born March 31, 1819, died July 6, I90I. Chancellor from October 29, 1894, to October 17, 1900 .

[ $\mathrm{ro4}_{4}$ ] 


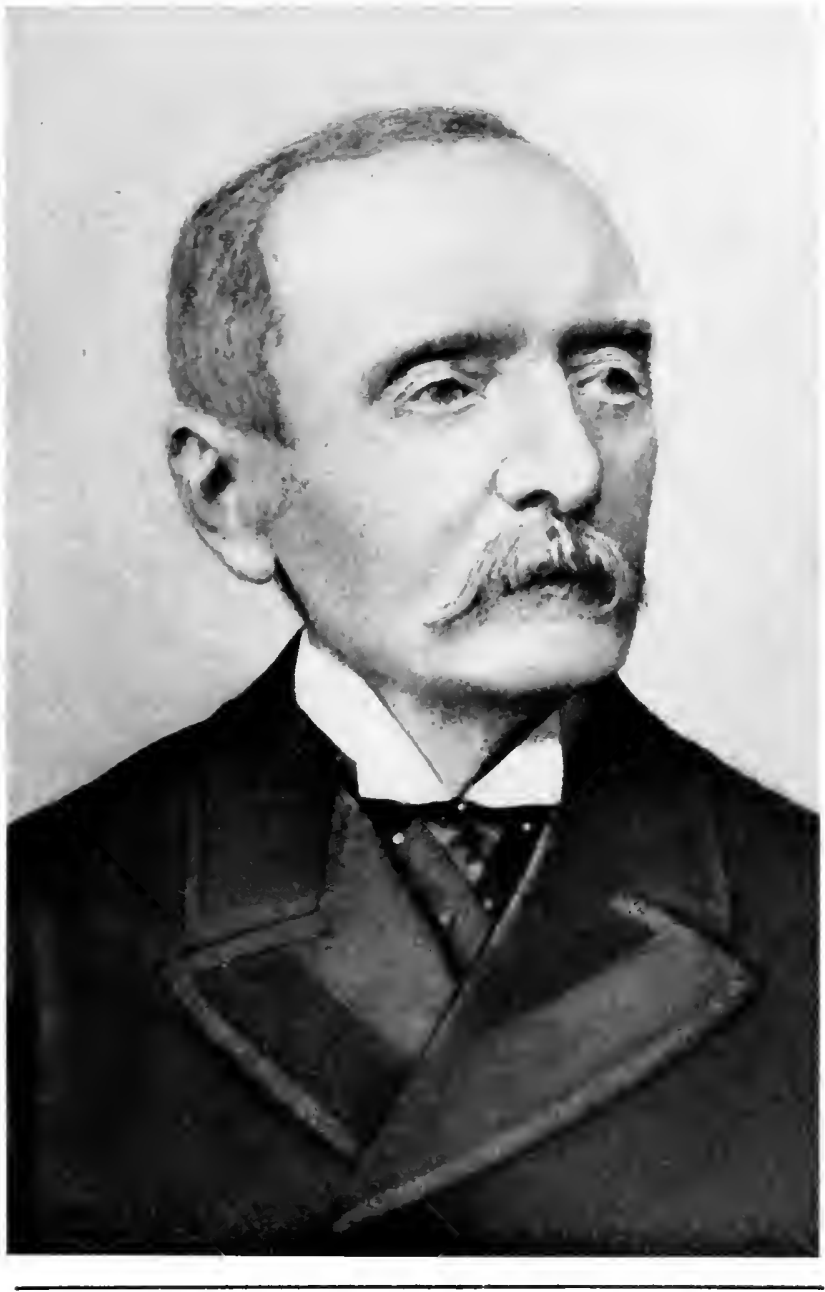

PRINCE HOHENLOHE-SCHILLINGSFÜRST Third Chancellor of the German Empire 



\section{CHANCELLOR AND HIS SUBSTITUTES}

Franco-Prussian War, entered the Prussian civil service and was transferred to the diplomatic service. In 1876 he was attaché at Paris, and in 1880 second secretary there, after a short interBernhard Heinrtch val in the Foreign Office in Berlin. In 1884 he was made first secretary to the embassy at St. Petersburg. In 1888 he was envoy at Bucharest and in 1893 ambassador in Rome. In 1897 he was appointed to the secretaryship of Foreign Affairs. His appointment to the chancellorship in 1900 was no surprise, since he had been for a long time regarded as the ablest representative of the German government, and as a man in complete harmony with the Kaiser's imperialistic views. He never attempted to create for himself a position similar to that of Bismarck, because it was simply impossible under a man like the present Kaiser. But he made the best of the situation, and by skilful, cautious and versatile diplomacy, he managed to stay in office for a long term, not being the absolute servant of the Kaiser, and yet enjoying his full confidence. $\mathrm{He}$ understood how to hold together the different elements in the German Reichstag and to find a majority for important measures. If we compare Bismarck with a pike in a fishpond we may well compare Bülow with an eel. The Annual Register of 1909 characterizes him as "a clever and witty speaker, a skilful debater, an adroit parliamentary strategist, with charming manners

1 Born May 3, 1849 . 


\section{GERMAN GOVERNMENT AND POLITICS}

and a highly cultivated mind." $\mathrm{He}$ had brilliant but not altogether solid qualities. With remarkable skill and tact he interpreted the several indiscretions of the Kaiser to Germany and the world so as to make them as harmless as possible without violating the Imperial prestige. He tried to break the power of the Clericals, who had so often abused their strong position in the Reichstag and attempted to rule with the help of a Conservative-Liberal bloc. But when he wanted to make concessions to the Liberals for their help and proposed an extensive inheritance tax as a part of the great financial reform of 1909 , he met with the strongest opposition from the Conservatives. Since it was impossible for him to humiliate himself by asking the Clericals for their help as a government party, he had to resign.

Theobald von Bethmann-Hollweg was born

Dr. Theobald ron BethmannHollweg in 1856 . He entered the Prussian civil service in 1882 and was successively Landrat, Regierungspräsident and President of the Province of Brandenburg. In 1905, he became Prussian Minister of the Interior and in 1907 Imperial Minister of the Interior and Vice-Chancellor. July 14, 1908, he followed Bülow as Chancellor. The present Chancellor is almost the exact opposite of Bülow. $\mathrm{He}$ is dry, cold, reserved, not charming, not an interesting speaker, little familiar with diplomacy, a typical Prussian officer of the civil service. At the same time he is very industrious, well informed, conscientious and cautious.

[ 106] 


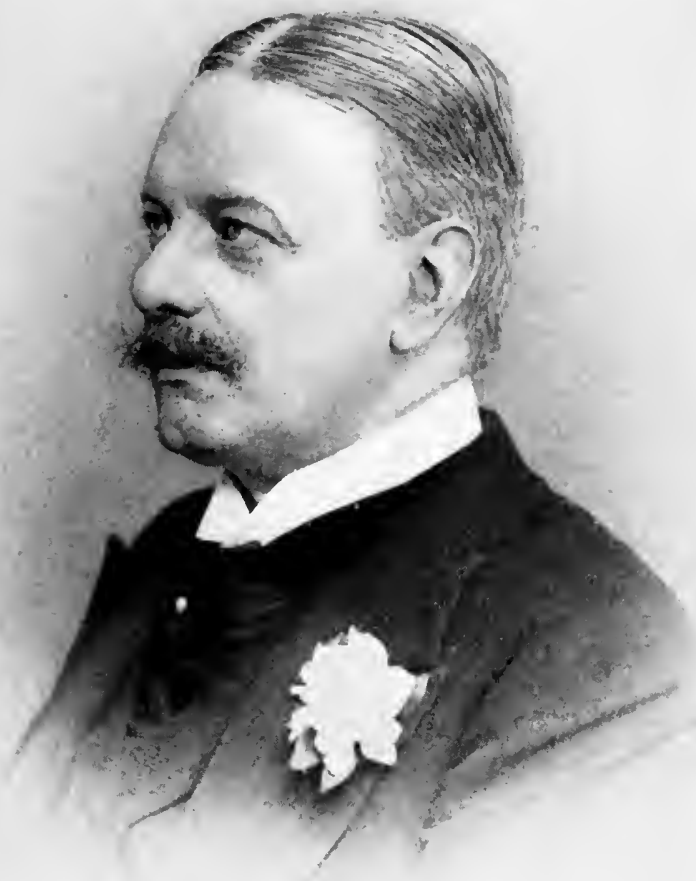

PRINCE, BÜLOW

Fourth Chancellor of the German Empire 

Soon after the foundation of the Empire, its administration became so complicated and the work so tremendous that it was impossible even for as experienced and hard working a statesman as Bismarck to oversee it all personally. It was necessary to establish one secretaryship after another. At the same time there was no provision in the Constitution or any statute for a general temporary substitute for the Chancellor, something which had twice become necessary before 1878. In order to settle this question a law was passed March 17, 1878. ${ }^{1}$

It provided first for a general substitute or Vice-Chancellor to be appointed by the Kaiser with the advice of the Chancellor. This is necessary, since the Chancellor still remains responsible in principle, and must therefore be in harmony with the Vice-Chancellor. The Chancellor may also at any time during the period of substitution perform any official function. It then provides for special substitutes to have charge of the highest Imperial offices under the Chancellor who may be charged with total or partial responsibility for the performance of their functions. This responsibility, like that of the Chancellor, is to the Kaiser. The central bureau which brings the different offices into the necessary contact with the Chancellor is the Reichskanzlei, created as such in 1879 .

1 "Gesetz betreffend die Stellvertretung des Reichskanzlers." 


\section{GERMAN GOVERNMENT AND POLITICS}

As a matter of practical politics a union of the The Imperial Chancellorship with the office of Prime Chancellor and Prussian affairs

Minister of Prussia seems always necessary although there is no legal requirement to that effect. Several efforts have been made to separate these two offices, but they have failed.1

The Prussian government, as a consequence of Prussia's leading position in the Empire, has to be closely in touch with the policy of the Empire. In a speech in the Reichstag March 5, 1878, Bismarck said that by experience he was convinced that the premiership of the Prussian ministry must be connected with the position of German Chancellor, "not because Prussian influence upon the Empire would otherwise be lost, but because German influence upon Prussia is lost, since the representation of the Empire in Prussia must be of such strength, as is only possible in the case of a leading minister and not with an inactive minister without office." For the same reason the general substitute of the Chancel-

1 Prince Bismarck ceded the Prussian premiership to Count Roon because of a difference of opinion between him and Roon, January I, I873. November 9, Roon resigned and Bismarck, who had during this period conducted only the foreign affairs of Prussia, reassumed the premiership. Caprivi resigned as Premier of the Prussian Ministry as a consequence of a defeat in the Lower Chamber, March 24, I892, but retained, like Bismarck, his position as Minister of Foreign Affairs. His defense of the separation of the two offices in the Reichstag, March 26, 1892, was diplomatic but not convincing, and disproved by the facts.

[ 108 ] 


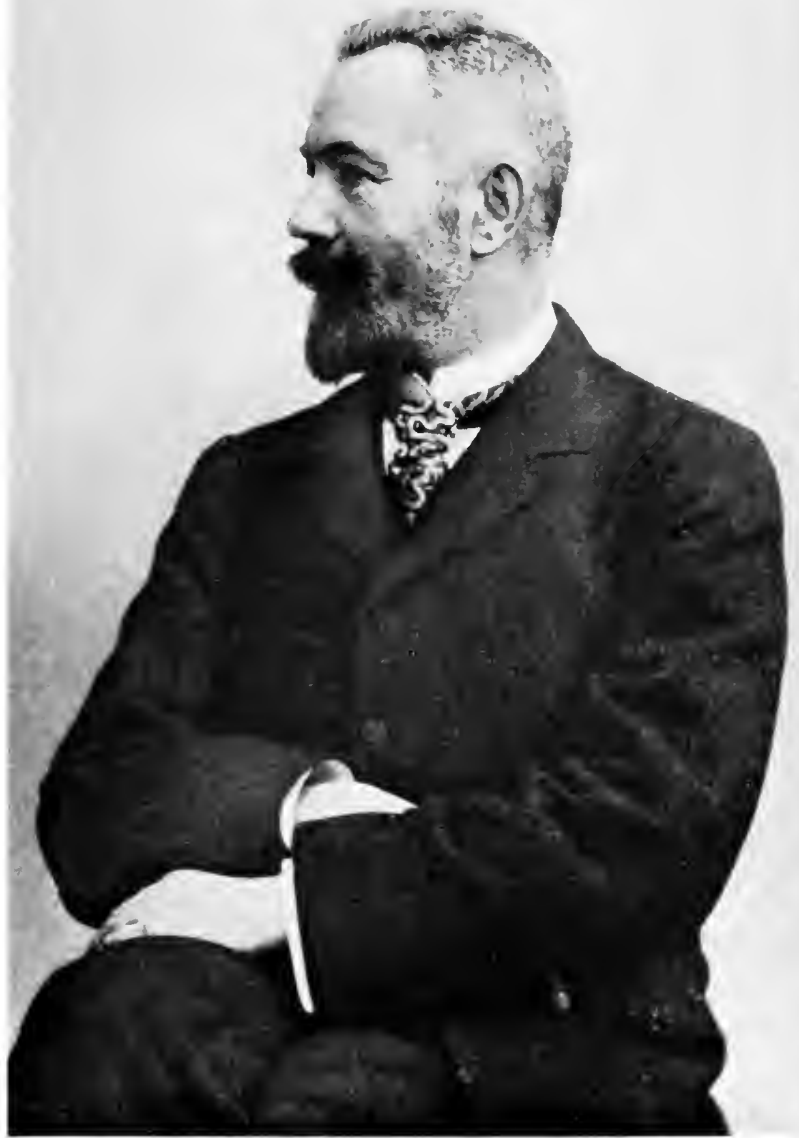

D. voN BETHMANN-HOLLWEG

Fifth Cbancellor of the German Empire 



\section{CHANCELLOR AND HIS SUBSTITUTES}

lor should be the substitute of the Minister-President of Prussia. ${ }^{1}$

\section{SELECTED BIBLIOGRAPHY}

Howard, B. E. “The German Empire," Chapter VI, Imperial Legislation.

Burgess, J. W. "Political Science and Comparative Constitutional Law," Vol. II, pp. 89 ff.

Bismarck, Otro von. "The Man and the Statesman." (Autobiography.)

Smith, Munroe. "Bismarck and German Unity."

Hohenlohe-Schillingsürrst, Ch. K. V. "Memoirs."

WiLE, F. W. "Men around the Kaiser." (Bülow - Bethmann-Hollweg - Tirpitz-Posadowsky - Dernburg.)

1 On March 10, 1877, Bismarck said in the Reichstag: "I have tried the experiment of ceasing for a time to be Prussian Prime Minister, thinking that I was strong enough as Chancellor. I have made a complete mistake by doing so and after a year I have repentantly returned and said, 'I will either resign or have the presidency of the Prussian Ministry again." Cf. also the interesting short chapter of Hänel, A., "Das Reich und der preussische Staat," in his "Studien zum deutschen Staatsrechte." II, 1, pp. 57 ff. 


\section{CHAPTER IX}

THE LA W-M A I NG PROCESS

THE science of public law discriminates be1 tween two kinds of law. The first and more Law, formal kind of law is known as Gesetz or ordinance and instruction simply Law. It can only be made by the action of Bundesrat, Reichstag and Kaiser in the form of a statute. The second kind of law is called Verordnung or Ordinance. It becomes binding on a citizen when it has been made in the manner prescribed by the Constitution and laws. It is a distinctly subordinate type of law. ${ }^{1}$

All the more important matters are regulated by law. The ordinance power cannot be exercised except by virtue of an explicit provision of the Constitution or a law. The law lays down general principles with regard to a particular subject, and in accordance with these principles ordinances are made by the executive to facilitate their administration. The ordinance power thus relieves the legislative bodies of much detail work. Furthermore, men constantly dealing with and trained for handling these details are best able to regulate them.

${ }^{1}$ Law is in French parlance loi, in Italian, legge; ordinance in French is arrête or décret and in Italian istruzione or regolamento.

[ IIIO] 


\section{THE LAW-MAKING PROCESS}

This means that those administrative officers who possess this power have great freedom in the interpretation of laws. They are, however, always under the control of the legislature and of the administrative courts.

By "instructions" are meant the rules which regulate the organization of an administrative department internally. They are therefore of purely administrative character and have effect only on officers.

As said before, any law, including amendments to the Constitution, may be proposed by either the Reichstag or the Bundesrat. The great majority of bills, however, originate with the Bundesrat, and most of them are prepared in the Prussian How a law of the Emplre Is made ministries. Here a thorough method is used to collect the necessary material. When this has been done a high administrative officer sees that the bill is in perfect form before passing it to the head of the department. The Kaiser, as such, has not the right to propose legislation. In practice, however, the result is the same as if he had been given the power by the Constitution, since he can introduce bills through his delegates in the Bundesrat. These bills are known as Präsidialanträge. The ministers of the different states frequently have conferences or correspondence relative to bills which are to be introduced in the Bundesrat, so that a certain consensus of opinion exists before the actual introduction. 


\section{GERMAN GOVERNMENT AND POLITICS}

According to the order of business in the Bundesrat the first reading of the bill does not lead to a vote. This is left to the second reading, at which time, however, it may be decided that the vote shall be taken on a future day. If less than fourteen votes are cast in opposition the first and second reading may take place on the same day. Otherwise an interval of at least five days is necessary between the two readings. A majority is sufficient to secure the passage of a bill except constitutional amendments and a few other classes of legislation. In case of tie Prussia's vote decides the matter. When a bill does not concern the whole Empire, only the votes of those states which are concerned are counted. This excludes the privileged states from voting upon subjects specifically left to their own management by the Constitution or treaties. If the delegate of a state is absent or uninstructed his vote is not counted.

The bill is then sent to the Reichstag "in the name of the Kaiser" (Article I6) through the Chancellor. His duty is purely formal and carries with it no right to alter the terms of a bill. legally passed by the Bundesrat.

The rules of the Reichstag ${ }^{1}$ require the bill in accordance with English and American practice to be read three times. The first reading takes place not earlier than thrèe days after the bill has been handed to the members of the Reichstag

[ I 112 2 ]

1 Geschäftsordnung 18-20. 


\section{THE LAW-MAKING PROCESS}

in printed form. No amendments can be proposed at this stage and the discussion is only general. After a bill has had its first reading, the Reichstag determines whether the bill shall go to a committee or not. This may also be done at any subsequent time prior to final passage. The second reading of the bill may not take place until the second day after the first reading, and, in case it is given to a committee, not earlier than on the second day after the printed propositions of the committee are in the hands of the members of the Reichstag. The bill is then discussed and passed upon article by article. The Reichstag may resolve for purposes of debate and vote to combine several articles or separate one. Amendments may be freely proposed at this stage. If the bill passes its second reading with amendments the "Bureau" (i.e., the president of the Reichstag together with the clerks) rewrites the bill as amended. The bill is read for the third and last time not earlier than the second day after it has passed the second reading stage. Amendments may be proposed, but will not be considered unless supported by at least thirty members. A general discussion, similar to that on the first reading, is followed by a more specific criticism, similar to that on the second reading. At the end, the bill is adopted or rejected, unless amendments have been made, in which case the final vote is postponed till the "Bureau" of the Reichstag has rewritten the amended bill. For 


\section{GERMAN GOVERNMENT AND POLITICS}

the final passage, an absolute majority of the members of the Reichstag is necessary, i.e., 199 votes.

By a majority vote, the Reichstag may decide to omit the second reading, or to have the first and second reading on the same day. A combination of the first and third reading is rejected if fifteen members are opposed to it. Such change from the usual practice must be decided upon before the debate begins.

Every bill, whether it originates in the Reichstag or Bundesrat, is sent to the latter for final consideration. This body, as the sovereign of the Federation, has the last word on all measures. It may even refuse to sanction a bill which it had passed originally. As it also originates most legislation, its preponderance in the parliament is very marked.

We have already seen that in the case of ordinary amendments to the Constitution, fourteen negative votes in the $B$ undesrat are fatal, and that proposals to change the special privileges of states may be vetoed by the votes of the state concerned. Still another exception is that the vote of Prussia is decisive with respect to army and navy matters and certain taxes, ${ }^{1}$ if it be cast in favor of maintaining the existing arrangements. $^{2}$ This means of course that Prussia has an absolute veto on any proposition affecting

1 Those specified in R. V., Article 35.

2 R. V., Article 5. 
these matters which is distasteful to her. The question as to whether grounds exist for the use of this veto is not decided by the Bundesrat, since the provision would then be meaningless, but is left to the Kaiser. He may refuse to sign or publish a law of this type which has been passed in the Bundesrat against the veto of Prussia.

After the Bundesrat has given its sanction, the bill is law so far as the subject-matter is concerned. In order to become effective it must be edited and published by the Kaiser. He has no veto in regard to the contents of the law, but he has the right and the duty to see that each law has been passed according to the prescriptions of the Constitution. He cannot, however, take into consideration violations of the rules of the two legislative bodies. If no objections can be raised, the Kaiser must promulgate the law. The standard form for the publication of a law reads: "We William, etc., German Emperor, etc., ordain ..., after consent of the Bundesrat and Reichstag, as follows: ..." The published law must bear the date of the publication, which counts as the official date of the law, and the counter-signature of the Chancellor or one of his legal substitutes. The publication must be made in the official "Reichsgesetzblatt" (Imperial Gazette), for the printing of which the Chancellor and his substitutes are responsible. ${ }^{1}$ The courts have

1 R. V., Article 2. 


\section{GERMAN GOVERNMENT AND POLITICS}

no right to pass upon the constitutionality of laws. ${ }^{1}$ The legislative bodies are superior to the courts.

\section{SELECTED BIBLIOGRAPHY}

Burgess, J. W. "Political Science and Comparative Constitutional Law," Vol. II, pp. 89 ff.

Howard, B. E., "The German Empire," Chapter VI, Imperial Legislation.

1 The Reichsgericht has declared that it has no right to pass upon the constitutionality of a law. "Entscheidungen des Reichsgerichts in Civilsachen." March 26, 1901, 48, 84. 


\section{CHAPTER $\mathrm{X}$}

THE A D I N ISTRATION OF

THE INTERIOR

$7 \mathrm{HE}$ broad principle of the relations of 1 legislation and administration, is legislative centralization and administrative decentralization. In general, the Empire has merely the supervision of the administration which is carried out by the officers of the several states. Administrative decentrallzation For this reason a full discussion of the bureaucracy in the Empire will be found in the volume in this series on the government of the several German states, and only the most important points concerning the Imperial Civil Service are touched upon in the following paragraphs.

Article 18 of the Constitution provided that every officer of the civil service was to be treated according to the law of his individual state. This system was too inharmonious to work well. In consequence, a codification of the law for Imperial officers, based upon the Prussian practice, was put into effect March 31, $1873 .{ }^{1}$

1 The Reichsbeamtengesetz, in new redaction with some changes, May 18, 1907; in addition to it the Besoldungsgesetz (law regulating the salaries) of July I5, 1909. 


\section{GERMAN GOVERNMENT AND POLITICS}

Imperial officers are those appointed by the Kaiser and those who, although appointed by. the sovereign of their state, are bound to obey the commands of the Kaiser. The first class are called direct; the second indirect officers. To the second class belong, for example, the officers of the post and telegraph service (except in Bavaria and Würtemberg), and military officers (except in Bavaria).

In case of conviction in disciplinary courts, Diciplin- the Imperial law is the same as that of Prussia, ary courts except that no arrest is allowed and the maximum fine is fixed at one month's pay in the case of salaried officers, and ninety marks in the case of unsalaried officers. Furthermore the regular increase of the salary may be stopped as a special punishment. Less severe punishments may be laid upon officers by their superior authority. Dismissal from office must be preceded by a regular process in a disciplinary court. Of these there exist two types, the Disziplinarkammern (Chambers of Discipline) or courts of first instance, and the Disziplinarhof (Court of Discipline) as court of appeal. The Chambers (now thirty in number) consist of seven members each of whom the president and at least three members must be judicial officers. Conflicts as to competence are decided by the Court of Discipline. The Court of Discipline has its seat at Leipzig. It consists of eleven members, made up of at least four delegates to the Bundesrat, the president,

[ I I 8] 


\section{ADMINISTRATION OF THE INTERIOR}

and five other members of the Supreme Court of the Empire, the Reichsgericht. ${ }^{1}$

The pensioning of Imperial officers is regulated in the Law of Imperial Officers (Paragraphs 34Pension 6o). The Chancellor, the Imperial Secretaries, and the Under-Secretaries of Alsace-Lorraine may demand that they be released from the service for no assigned reason. They must in that event, if they have served at least two years, be given a pension amounting to a minimum of one fourth of their salary.

According to Article 4, 3-4, of the Constitution, legislation concerning measures, weights, currency and banking is given to the Imperial Weights and authorities. Imperial law has now completely measures introduced the decimal or metric system in weights and measures. ${ }^{2}$ The local supervision of the correctness of weights and measures is exercised by special offices of the several states, the Eicbungsämter, under the supervision of an Imperial office in Berlin, the Normal-Eicbungskommission. Bavaria has her own central office, but is obliged to take her standard meas-

1 Military officers under the exclusive authority of military commanders have special disciplinary courts. (See Reichsbeamtengesetz, paragraphs 120-123.) Also members of the Reichsgericht, the Rechnungshof, the Reichsamt für das Heimatwesen, and judicial officers of the army and navy.

2 E.g., "Masz- und Gewichtsordnung vom 20. Mai, 1908," "Schiffsvermessungsordnung vom I. März, I895," issued by the Bundesrat as an ordinance, "Münzgesetz vom I. Juni, 1909." 


\section{GERMAN GOVERNMENT AND POLITICS}

ures from the Imperial office and her technical regulations must be in harmony with those of the office in Berlin. The supervising office for the measurement of electric energy is an Imperial office in Berlin, the Pbysikaliscb-Tecbniscbe Reichsanstalt.

The measuring of sea vessels is under the supervision of both central Imperial and local state offices.

Before the foundation of the Empire coinage Currency and banking in Germany were in serious need of and banking reform. Different states had different monetary systems and in all circulated a mass of obsolete coinage. All adhered to a silver standard. All issued independent currency and there were private banks of issue acting under differing charters, and with varying responsibilities. The Imperial Constitution gave to the Empire the power to regulate the monetary system and by a series of statutes enacted between 1871 and 1875, this problem of money and banking was solved.

The gold standard has been adopted and one kilogram of this precious metal makes 279 ten-mark pieces. The one-mark (silver) piece is the unit of the decimal monetary system of the Empire. It equals about twenty-four cents of American money. The mints are state institutions and each state has the right of establishing one. The coinage of money, however, is regulated by the Bundesrat and supervised by commissioners

[ 120 ] 


\section{ADMINISTRATION OF THE INTERIOR}

who are appointed by the Chancellor. Twentymark gold pieces may be coined also for private persons in accordance with certain regulations. The issue of coin other than gold is a monopoly of the Empire.

The law of April, 1874, provided for the extinction of the paper currency of the several states and the creation of new paper money consisting of Reichskassenscheine (Imperial Treasury notes) and Banknoten (bank notes) The first, issued by the Reichsschuldenverwaltung (Office for the Administration of Imperial Debts), are not legal tender. The Banknoten are issued by five special privileged note banks in accordance with legal regulations. These are the Reichsbank (Imperial Bank) in Berlin, one other bank each in Bavaria, Würtemberg, Baden and Saxony. These banks are under the strict supervision of the Empire, salutary state regulation being the principle relied upon to give notes their security, rather than the deposit with the government of specific property as in the American national banking system. The note issue is limited by imposing a tax on all notes beyond a certain amount.

The Reichsbank was created out of the "Bank of Prussia," which was originally a government bank with capital supplied by the state. The Empire purchased this institution from Prussia, and by the bank law of 1875 founded it as a private corporation under the management and bank 


\section{GERMAN GOVERNMENT AND POLITICS}

supervision of the Empire. It is a stock company, the whole of its capital being in private hands. Its head is the Imperial Chancellor, or, in case of his unavoidable absence, a substitute appointed by the Kaiser. He directs the policy of the bank in accordance with the provisions of the Bank Law. $\mathrm{He}$ is the president of the Kuratorium, ${ }^{1}$ which is in charge of the Imperial supervision of the Reichsbank. Under the Chancellor, the Reichsbank Direktorium, an executive board, has immediate control of the banking business. Its members are appointed for life by the Kaiser, upon nomination by the Bundesrat. The interests of the shareholders are secured by their general meeting, and by an elected advisory committee. The Reichsbank has a ten year contract with the Empire to conduct the financial operations for the imperial treasury. The present contract will expire in 1919.

In the German Empire, as in all civilized coun-

Protection of patents tries, new inventions enjoy the protection of the government. ${ }^{2}$ The Patentamt (Patent Office) in Berlin grants on application patents for all new inventions which are of practical use. The period during which an inventor is allowed a monopoly of his invention is fifteen years, for which privilege a yearly increasing fee has to be paid. In

1 The Kuratorium consists of the Chancellor as its president, one member appointed by the Kaiser, and three by the Bundesrat, for a term of two years.

2 About the details see Patentgesetz of April 7, 1891.

[ 122 ] 


\section{ADMINISTRATION OF THE INTERIOR}

case a patented invention is not used within three years after its grant, the patent may be revoked by the Patentamt. Furthermore the Empire may buy a patent from an inventor whenever it is in the interest of the general public welfare, the army or the navy. In a similar way designs and trademarks are protected by special laws, the former for three years, and the latter for ten years, with the privilege of renewal.

Since May 1, 1903, the German Empire has belonged to the International Union for the Protection of Industrial Property. All the countries in this union give the same protection to inventions, designs and trade-marks which is granted in the country of their origin, if the application for protection is made within reasonable time.

The Stein-Hardenberg reforms of I 8 I I embodied for the first time in the Prussian trade laws the principle of industrial freedom as taught by Adam Smith. This principle was fully recognized in the law regulating trade and industry of the Industry Empire, the Gewerbe-Ordnung (Trade Law). ${ }^{1}$

In the beginning of the seventies a movement to return to a system of protection and paternalism, a neo-mercantilistic tendency, started in Germany, which has grown stronger and stronger. The principle of industrial freedom was greatly

1 This law is the Gewerbe-Ordnung of June 21, 1869, of the North German Federation, which was taken over by the Empire in $187 \mathrm{r}$. It has undergone many very important changes. 


\section{GERMAN GOVERNMENT AND POLITICS}

modified so that at the present time it cannot be said to obtain in Germany. The first step in this direction was the introduction of voluntary guilds in 1878 , which were charged with important functions regarding the training of apprentices. Many other amendments in favor of the guild system and restriction of trades and industries followed. The purpose of this legislation was to restore the craft of the artisan to its former efficiency and dignity, protect artisans against capitalists, and promote selfrespect and a proper class spirit. In order to attain this purpose, the Gewerbe-Ordnung officially abbreviated G. O.- prorides for protection against unjust exploitation, guarantees efficient training for certain occupations, and regulates an official representation of class interests and protective measures against unfair competition.

The following outline of this law illustrates in detail these general principles of the activity of the German government in the regulation of trade and industry.

The Gewerbe-Ordnung distinguishes between located industry and trade, unsettled industry and trade, and market industry and trade.

Located industries and trades have to be registered; open stores and restaurants must give the full name of the owner on the outside of the premises. A special official consent is necessary for the establishment of factories and ma[124] 


\section{ADMINISTRATION OF THE INTERIOR}

chines disagreeable, detrimental or dangerous to the environment; for instance, steam-engines, gunpowder factories, wind motors, etc. An "approbation," that is, a consent based upon the passage of an examination, is necessary for certain professions and occupations; for example, medicine in its various branches, chauffeuring, several branches of service on ocean vessels, such as piloting. A special concession is also required for certain institutions (medical, theatrical, liquor, loan, employment, immigration, emigration, private insurance, mortgage banking). Other occupations may be prohibited to persons unfit by character, especially dancing, gymnastics, trade with explosives, information bureaus, and marriage bureaus.

Tradesmen who travel are required to purchase a certificate granted to them by an administrative authority of their place of residence. The grant of the certificate depends on certain qualifications.

The buying and selling at markets and fairs is free, save a fee for the stand. The number and duration of fairs and markets is fixed by the administrative authorities.

Title VI of the ten titles of the G. O. regulates the organization of artisans in guilds or Innungen. These are created for the cultivation of class honor, corps spirit, promotion of a healthy relationship between masters and helpers, and arbitration between them in case 


\section{GERMAN GOVERNMENT AND POLITICS}

of differences; also for the general promotion of common interests, the care of employment bureaus, and for the regulation of the affairs of helpers. The creation of guilds is either free or obligatory, as regulated in the G. $O$. The guilds are legal corporations under the supervision of administrative authorities. Several guilds of the same administrative districts may*create a committee for the promotion of their interests. The states of the Federation are obliged to create chambers of artisans for larger districts. These represent the interests of artisans analogous to the representation of commercial interests in chambers of commerce.

Title VII of the G. O. deals with the legal status of workingmen, and especially their protection. It fixes the maximum of working hours, Sunday rest, the legal status of minors and children, working women, wages (which must be paid in German money, the so-called truck system being prohibited), contracts, length of instruction for beginners, the acquisition of the master title and rights connected with it, protection of life, health and morality of workingmen and women.

The enforcement of the laws and regulations laid down in the G. O. is in the hands of special civil service officers, the Gewerbeinspektoren or trade inspectors, who are aided by the local police. They are appointed by the governments of the several states, and are obliged to make [126] 


\section{ADMINISTRATION OF THE INTERIOR}

frequent and unanticipated inspections and to place before the Imperial legislature annual reports about their activity. Punishments for the violation of the G. O. are laid down in its last title.

The supreme supervising organ is the Secretariat of the Interior of the Empire. The local supervision is centralized in the Ministries of Commerce and Industry, or special Departments of Industry of the several states.

A special Beirat für Arbeiterstatistik or "Council for Workingmen's Statistics" has been created at the Imperial Office of Statistics for the collection of facts concerning the promotion of the interests of industrial workers.

For the settlement of disputes between workingmen or between employers and employees, special industrial courts, the Gewerbegerichte or Trade Courts may be created. They consist of a chairman and four members, selected from employers and employees.

Perhaps no field of German governmental activity has been more admired and used as an example than her system of compulsory insurState insurance ance. In Germany, even the severest critics of the form in which it is now managed admit its advantages. Thus the foremost German critic of its working in the Empire, Prof. L. Bernhard, says: ${ }^{1}$

"A survey of medical literature clearly shows

1 Taken from L. Bernhard, "The Future of Social Policy in Germany," rgr2. Translated by L. H. Gray. 


\section{GERMAN GOVERNMENT AND POLITICS}

that instruction in simulation and aggravation has actually become a special science since the introduction of workingmen's insurance and through workingmen's insurance. But even simulation itself is not the worst. A far more dubious phenomenon is the formation in the consciousness of the masses of a trend of thought which creates close connections between every illness and a title to a pension. As a result attention is ceaselessly directed to the conditions connected with one's own body, and those nervous phenomena appear which are called 'pension hysteria' by physicians. The social policy of Germany leads to an elimination of private initiative, to a check upon the spirit of enterprise, and to an annihilation of independence, and countless bureaucratic interferences impede the progress of our industries."

Yet on the other hand Professor Bernhard admits that "Protection of workingmen has proved itself to be so necessary and so beneficial that it is the bounden duty of all to speak of these matters with respect and restraint. We all know that the concept of insurance is sound at heart, . . I It was indeed important to balance the dangers of the workingmen's tasks, and to offset sickness and dread of old age."

The principles upon which the German government initiated its marvelous system of state insurance were laid down in the famous Imperial Messages of November 17, 1881, and April 14, [ 128 ] 


\section{ADMINISTRATION OF THE INTERIOR}

1883. In the first message, Kaiser William I said: "The abolition of social evils should not be accomplished exclusively by repression of social excesses but equally by positively promoting the welfare of the workingmen. We consider it Our Imperial duty to impress the Reichstag with the necessity of promoting the welfare of the workingmen, and We would look back with greater satisfaction to all Our successes with which God has apparently blessed Our government, if We succeeded in taking away with Us the assurance that We have left behind Us for the Fatherland new and lasting certainty of its inner peace, and for those who need help greater security and assistance, to which they are entitled."

Since then the system of State Insurance has been steadily built up to the present time.

The essential characteristic feature of the German State Insurance is obligatory membership. The insurance organs, that is, communes and sick-benefit associations of different types, or coöperative associations, are conducted from the standpoint of reciprocity and self-government. The executive officers are honorary officials elected by proportional vote from among the employers and employees. The states have only a general supervision over these insurance organs through insurance offices, of which there are three kinds: lower, superior, and one "Supreme Imperial Insurance Office," the Reichs- 


\section{GERMAN GOVERNMENT AND POLITICS}

versicherungsamt. ${ }^{1}$ All these offices contain some lay members who are selected equally from the employers and employees; the superior offices employ also judges, and the Supreme Office includes, besides professional officers, who are appointed by the Kaiser upon recommendation of the Bundesrat, some members of the Bundesrat. All these officers have special judicial departments for the settlement of disputes arising from insurance, the Supreme Office being the final court of appeal.

The three kinds of insurance are: sick, accident, and old age and invalid insurance.

All employees earning an income of less than 5,000 marks are required to join an accident insurance association. If their income is less than 2,500 marks they must likewise join a sick insurance association, and if it falls below 2,000 marks they must join an old age and invalid association.

The insurance against sickness gives the insured sufficient help in case of sickness for at least twenty-six weeks. Young mothers receive financial assistance for eight weeks after giving birth to a child. In case of death the relatives of the deceased receive a sum equal to at least twenty times the average daily wages of the deceased. The expense of the insurance is borne one

1 Bavaria, Saxony, and Baden have a "Supreme Insurance Office" of their own, which in many cases takes the place of the Imperial Office.

[ 130 ] 


\section{ADMINISTRATION OF THE INTERIOR}

third by the employees and two thirds by the employers.

The accident insurance entitles the insured member to financial compensation for accidental injury or death not caused by his own gross negligence. In case of permanent injury the compensation consists of free medical treatment beginning with the fourteenth week ${ }^{1}$ and a pension fixed according to the severity of the injury up to a maximum of two thirds of the last annual income of the injured person. In case of death the near relatives are entitled to a pension and a Sterbegeld or "Death-Money," equal to one fifteenth of the last annual income of the deceased. The expense of the accident insurance is borne entirely by the employers.

Members of the old age and invalid's insurance associations are entitled to a pension at the beginning of permanent invalidity, or always after the age of seventy years. Invalid widows, and orphans under fifteen years of age, of insured persons, are also entitled to a pension. The expense of this insurance is borne by the government, the employers and the employees. The government pays for every invalid's pension yearly fifty marks. The rest is equally divided between the other two parties.

All the different insurance laws, eight in number, have been revised enlarged and edited as one

1 During the first thirteen weeks, the sick insurance association has to give its assistance to the injured person. 


\section{GERMAN GOVERNMENT AND POLITICS}

harmonious law, the Insurance Act of July 19, I9I I.

A few figures may serve to illustrate the enormous proportions of the system. In I9I2 fourteen million people were insured against sickness, twenty-five million against accident, and sixteen million against old age and invalidity. About nine billion marks have been expended since the passage of the insurance laws.

The Constitution Article 4, I5, gives the EmMedical pire the right of legislation in regard to medical erinary police and veterinary practice. This is under the care and supervision of the Secretariat of the Interior. The technical questions are handled by one of its departments, the Gesundheitsamt (Health-Office). Several Imperial laws directly affecting the medical police have been passed; for example, the law of 1874, making vaccination compulsory; a law of 1900 for the extermination of contagious diseases; the pure food law of $\mathbf{1 8 7 9}$, including the supervision of toys, colors, petroleum, etc.; a law of 1900 concerning the inspection of meat; the international convention of 1893 against cholera; the international sanitary convention of 1894 for the inspection of pilgrim vessels from India; the international convention of 1903 concerning measures against pests, cholera, and yellow fever.

In regard to veterinary police, several Imperial laws have been passed; for instance, the law of I 909 concerning animal epidemics; the law of the North German Federation of 1869 concerning

[132] 


\section{ADMINISTRATION OF THE INTERIOR}

measures against epidemics of cattle; the law of 1876 in regard to the removal of contagious material in freight trains; and a few others. The administration of these laws is left almost entirely to the several states.

\section{SELECTED BIBLIOGRAPHY}

Ashley, A. "The Social Policy of Bismarck."

DAwson, W. H. "Social Insurance in Germany, I883-I9Ir." "The Reichsbank, 1876-1900." Published under the auspices of the Reichsbank.

BArKer, J. E. "Modern Germany," Chapters XXVIIIXXX. 


\section{CHAPTER XI}

\section{THE FINANCES OF THE}

GERMA N EMPIRE

7 HE financial calculations of private persons 1 are based upon their income; those of a state, upon its necessary expenditures. As a rule, income is not an end in itself with the state. Its amount is prescribed by the needs of the state.

When we look at the history of the expendi-

The development of the expenditures of the Empire tures of the German Empire, we find that they have steadily and enormously increased. This is partly due to the development of the original administrative branches, and partly to the fact that the Empire has started new spheres of activity since its foundation. Aside from the regular increase in the size of the army, the improvement of its rations, the higher cost of living, and the introduction of modern hygiene in the barracks have increased the standard of expenditure and raised the total cost of army maintenance to three times the expenditure of 1872 . The cost of the interior administration is also three times as high; that of the administration of foreign affairs four times as high. 1 The expenditures for the

1 E.g., there exist now more than five times as many consulates as in the beginning of the Empire.

[ 134 ] 


\section{THE FINANCES OF THE EMPIRE}

large and increasing Imperial debts must also be reckoned in as an important factor.

Of new activities which consume great amounts of money, should be mentioned, in the first place, the creation of the German navy. The current expenditures for the navy alone amounted to $197,396,000$ marks in the year 1913.

Furthermore, the acquisition and administration of colonies have greatly influenced the finances of the Empire. The revolts in South Africa and the expedition to China in 1900 cost the Empire 720 millions of marks. Another tremendous increase was caused by the contribution of the Empire to the system of compulsory state insurance which was started in the eighties of the last century. The patent office, the sanitation office, the supervising authorities for private insurance companies, contributions to scientific investigations, subventions for steamship companies, and other new expenditures for cultural purposes, help to increase the cost of the maintenance and development of the government. As a whole the expenditures of the German Empire, from 1872 to the financial reform of 1909, multiplied about four times. They rose from about 400 millions to 1,650 millions of marks.

Let us now examine the sources of the income of the German Empire. The nature of a federation requires a division of the income between the union and the several states. The stronger the Federal and state finances centralization, the greater the federal expendi- 


\section{GERMAN GOVERNMENT AND POLITICS}

tures, and the more therefore is the union entitled to remunerative taxes. On the other hand, the several states are usually the original political units of a federation and have reserved a large number of taxes for themselves which they are not willing to transfer to the union. The most natural division of the income is the general principle found alike in Germany, the United States and Switzerland that customs duties and indirect taxes are reserved to the union. In addition, checks, mortgages, railroad tickets, etc., are taxed by the German Empire on account of their mobility. This principle of division of Imperial and state finances, however, is not strictly carried out. Excises on beer and wine are laid by some of the states of Southern Germany, and in latter years the Empire has levied taxes on immobile values, such as the inheritance tax, taxes on unearned increment, etc. Another important exception to this principle are the so-called Matrikularbeiträge, or Contributions of the States, which will be discussed later on.

The income of the Empire, other than from its The property, consists therefore at present of the system of Imperial income following:

r. Customs duties. Originally, the Empire started with a low protective tariff. But for several reasons, mentioned in other parts of this volume, ${ }^{1}$ it changed in 1879 to a high protective tariff, which was increased in 1885 and 1887 .

1 See pp. $224 \mathrm{ff}$.

[ 136 ] 
The year 1892 brought the commercial treaties with Austria, Italy, Switzerland, Belgium, Roumania, Serbia and Russia, which, since they were concluded for a fixed period of twelve years, gave German products a greater market stability. A significant feature of these treaties was the lowering of the duties on agricultural products. The agricultural interests fought bitterly against these treaties, and after hard struggles a tariff was passed in 1902 which went into force in 1906. This tariff again increased the duties on corn, whereupon the existing commercial treaties were amended. Most of the commercial treaties will expire at the end of the year 1917. The customs duties are the main source of the Imperial income, constituting about one half.

2. Excises collected on brandy, beer (excluding South Germany), burners and lamps, salt, champagne, tobacco, cigarettes, sugar and matches.

3. Stamp taxes collected on playing cards, bills of exchange, checks, foreign banking notes, shares, deeds, mortgages, bills of sale, bills of lading, betting and lottery tickets, railroad tickets, license cards for automobiles used for business purposes, the remuneration of members of the supervising boards of stock companies. Among these taxes we may enumerate also the Imperial inheritance tax, although it is not a stamp tax in its form. One quarter of this goes to the several states. The tax progresses according to the 


\section{GERMAN GOVERNMENT AND POLITICS}

grade of relationship and the amount of the heritage. Since 1911 the Empire has derived an income from a tax on the unearned increment of real estate, of which 50 per cent goes to the Imperial Treasury, ro per cent to that of the several states, and 40 per cent to the communes.

4. Contributions of the several states, called Matrikularbeiträge, ${ }^{1}$ calculated according to the number of inhabitants of the states. Originally these contributions were considered only a temporary institution. R. V., Article 70 , provided that they should be in existence only until the Empire would have acquired other means of income. Bismarck disliked the idea that "the Empire was an undesirable boarder of the several states," 2 and wished to abolish the matricular contributions entirely. ${ }^{3}$ But for political reasons the Reichstag refused to abolish them. Since they yearly require the consent of the Reichstag, they give a decided and frequent political control over the finances of the Empire. The final desire of the majority of the Reichstag has been to establish the political responsibility of the Secretary of Finances, but since the government always has been opposed to even the slightest tendency toward ministerial responsibility it

1 Switzerland has also legally recognized the system of Matrikularbeiträge, but other sources of income have made it unnecessary to collect contributions from the several states.

2 Speech in the Reichstag of May 2, 1879.

${ }^{3}$ Speech in the Reichstag of March 10, 1877.

[ 138 ] 
has insisted on exercising a constant control over the finances of the Empire through its consent to the contributions. When, therefore, the Reichstag in the year 1879 passed the high protective tariff, it saw to it that the contributions would not be made unnecessary on account of the large income from the customs duties. For this reason it created an artificial deficit by the passage of the so-called clausula Frankenstein. ${ }^{1}$ According to this clause a considerable part of the income from the customs duties had to be given to the states, which in their turn had further on to fill out the deficit of the Empire by matricular contributions. The system of these exchanges between the Empire and the states has been frequently changed ${ }^{2}$ but never abolished.

In the year 1904 the clause of R. V., Article 70, "so long as Imperial taxes are not introduced," was eliminated and thus the matricular contributions are now recognized as permanent taxes. Since 1909 the exchange between the Empire and the states is made through the brandy tax. The income from this tax is transmitted to the states. These have in turn to contribute to the income of the Empire according to the deficit of the Imperial Treasury. And then again the Empire hands over the surplus of its income to the states. This system is artificial and compli-

1 So called after its clerical originator in the Reichstag.

2 For instance, in 1904 and 1906 the contributions were decreased. 


\section{GERMAN GOVERNMENT AND POLITICS}

cated in the highest degree, and a change is greatly to be desired.

The Imperial Fiskus or Reichsfiskus, is the Fiskus, German Empire in its legal capacity as owner property, of property, for example, railroads, posts, teleImperlal graphs, etc. As such it is treated like any public
debts corporation. Alsace-Lorraine and the protectorates have their own Fiskus.

The Imperial property of Germany is very small compared with that of the states. It consists of the railroads in Alsace-Lorraine, which were bought from France in $187 \mathrm{I}$ for 325 million francs; the Imperial war treasure, consisting of 120 million marks in gold, and kept for costs of mobilization; the Imperial Veterans' Fund, which originally consisted of 561 million marks but which had sunk to about 130 million marks in 1909. The money for the last two funds was reserved from the French war indemnity. Further, there should be mentioned the share which the Empire receives from the Imperial Bank, the Government Printing Office, the "Imperial Gazette," a few Imperial railroads and the posts and telegraphs. Besides this so-called financial property, the Empire possessed also so-called administrative property, e.g., administrative buildings, fortresses, military and naval stations, etc.

Corresponding to the classification of property, the debts are divided into:

I. Finance debts; e.g., those made for extraordinary needs; and,

[ 140 ] 


\section{THE FINANCES OF THE EMPIRE}

2. Administrative debts; e.g., those made for current administrative purposes.

The latter may be incurred by any administrative department on the basis of the budget. The others may be created only by virtue of special laws. Of these distinction is to be made between Reichskassenscheine, that is, actual paper money bearing no interest and exchangeable for cash at any Imperial office; Schatzanweisungen, that is, drafts, bearing interest and issued for a fixed term; and Reichsanleihen, which differ from the former drafts in that their term of expiration is not fixed.

The German Empire started with finances in good condition. It had no debts. The 770 million marks of debts of the North German Federation and of the Franco-German War were paid by the French indemnity in the year 1873 . The

Outline of the financial history of Germany sources of Imperial income, however, were very poor in the seventies. The contributions of the states until 1879 amounted to about one quarter of the entire income of the Empire. In the year 1878 the income, other than from contributions, had increased by twenty-nine million marks only, while the expenditures had increased by 100 million marks.

Bismarck saw clearly the dangers of insufficient sources of income for the Empire. Mainly to improve the Imperial finances and give the Empire an independent large revenue, he introduced, in the year 1878 , the protective tariff and, unsuccessfully, planned the Imperial ownership of rail- 


\section{GERMAN GOVERNMENT AND POLITICS}

roads, the tobacco monopoly, and later on the brandy monopoly. Unfortunately, the financial reform of Bismarck was reduced in its effect by

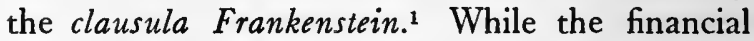
reform of 1878 opened a splendid source of income - the customs duties - the uncertainty of the finances remained on account of this distracting clause.

During the period from 1879 to 1900 , the expenditures of the Empire increased rapidly. The income consisted mainly of contributions and of loans. As a matter of fact the surplus of the customs duties paid to the states surpassed their contributions from 1879 to 1899 by 390 millions. On the other hand, the debts which the Empire incurred during this period amounted to 2,300 million marks. And furthermore, these debts were made without any arrangement for their repayment. Since 1900 the expenditures increased more than ever, while, in spite of minor reforms, the income did not increase correspondingly. In 1908 the Imperial debt had reached the sum of $4,253 \frac{1}{2}$ million marks.

The financial history of the Empire is shameful when we consider the permanent peace and prosperity of the country since its foundation. It was indeed time for change when, in November, 1908, the Bundesrat proposed a reform of the financial system of the Empire, for which 500 million marks were demanded by the govern-

$$
1 \text { Cf. p. } 138 .
$$

[ 142 ] 


\section{THE FINANCES OF THE EMPIRE}

ment. Although the reform, carried out in the year 1909, was far behind the expectations of the leading authorities on finance and favored the wealthy classes unduly, it nevertheless made considerable improvement in the situation. The aim of the reform was to stop the creation of more debts, and to provide for the existing debts systematically; to bring expenditure and income into harmony; and to regulate the financial relations between the Empire and the states. The last of the three reforms has not been accomplished, and it remains a problem for the future. As long as the Empire has not its own independent revenue, and with it full financial responsibility, the situation is neither logical nor satisfactory.

The latest change in the financial system of the German Empire took place June 30, 1913. The increase of the army, necessitated by the secret military agreement between Germany's enemies known to the German government, required an increase of almost a billion marks of extraordinary non-recurring expenditure, besides an increase of the current expenditure. To meet the first a so-called "defense contribution" or Wehrsteuer was accepted. This was a nonrecurring direct property tax on all estates exceeding 10,000 marks, ${ }^{1}$ and progressing at the rate of

1 Persons with an income of less than 4,000 marks were exempt up to 30,000 marks; persons having an income of less than 2,000 marks were exempt up to 50,000 marks. 


\section{GERMAN GOVERNMENT AND POLITICS}

from 0.35 to $1 \frac{1}{2}$ per cent of the property. For the increase of current expenditures a property increment tax, a stamp and a sugar tax were decided upon. The first of these three taxes was passed in the Reichstag against the opposition of the Right; the second and third against that of Social-Democrats. The Poles and Alsatians, objectors on principle voted against all three.

The requirements for the Imperial budget, that

The budget is, the estimates of the future income and expenditures of the Empire, are laid down in R. V., Article 69. This article says, in the first place, that the budget must be determined by law. It is, in other words, an administrative act passed in the form of an Imperial law. Article 69 also lays down that the budget must be made for a year. Since 1876 , the fiscal year of the Empire has been fixed from the first of April to the thirtyfirst of March. The nature of the budget being that of a preliminary estimate, it must be fixed before the beginning of the fiscal year. Furthermore, the budget, according to the Constitution, should as a rule be put into the form of one harmonious law. In fact, however, there are separate special budgets for unforeseen expenses or in case of an unavoidable change in the sources of income.

The budget is naturally only a program which the administration follows without binding itself absolutely by it. The form of the budget law is not laid down by the Constitution, but has de-

[ 144 ] 
veloped by practice. It consists of an introduction, the budget-law proper, and the budget itself. Logically, the budget itself is divided into two main portions: Expenditure and Income. The expenditures are divided into continuing and annual expenditures. The latter are designated ordinary expenses, that is, those which are balanced by regular income; and extraordinary expenses, those which are balanced by the Imperial financial property or loans. The Expenditure is classified according to the secretariars and central administrative bureaus; the income, according to its sources. The income is counted as net income.

In regard to the military budget a peculiar situation exists. According to the agreement of November 23, 1870, Bavaria's part is given as a lump sum while she has the right to determine the detailed military budget for herself. The protectorates, since 1892 , have had their own budgets.

According to practice, the Secretary of Finance fixes the budget, in coöperation with his colleagues. It then goes to the Bundesrat, where it is discussed with the assistance of the Ministers of Finance of the several states. After the budget has been fixed by the Bundesrat, it is transmitted to the Reichstag. This body may criticize and amend it in its most important committee, the Budget Committee, and in pleno. It is a principle clearly recognized by all German 


\section{GERMAN GOVERNMENT AND POLITICS}

students of constitutional law, that neither the Reichstag nor the Bundesrat has a right to refuse the expenditures necessary for carrying on the existing machinery of the state.

New sources of income can be opened only with the consent of the Reichstag and Bundesrat. Their consent is also necessary for loans, issuing of Imperial notes, and any exchange of financial property.

According to R. V., Article 72, the Chancellor

Control over the finances of the Empire must every year give an account to the Bundesrat and Reichstag of the use of the Imperial income. For this purpose an itemized statement of the financial transactions of all the departments is prepared at the end of every budget period. This statement is then audited by the most careful and thorough methods, by the Court of Control, the Rechnungshof. 1 This office can demand information from every administrative department, and appoint commissions of investigation. The examined statement, together with a memorandum, is then placed in the hands of the Bundesrat and the Reichstag, which refer it for detailed examination to their special committees. Thereupon follows the discharge of the Chancellor from further responsibility. No provision has been made as yet for cases in which the legislative bodies might not be satisfied with the result of their investigations.

1 As given in the Reichsschuldenordnung of March 19, 1900.

[ 146$]$ 
The supreme office for the supervision of the Imperial finances is the Reichsschatzamt, which was created as a secretariat under the Chancellor in the year 1879. Besides this general central organ there are several independent Imperial finance offices. These are:

I. The Office for the Administration of the Debts of the Empire, or the Reichsschuldenverwaltung. This office, for its main business, is directly responsible to the Chancellor. For its less important business, it is subject to the supervision of the Secretary of Finances. This office is also in charge of the issuing of the Reichskassenscheine ${ }^{1}$ and of the editing of the "Book for the Registration of the Imperial Debts" or the Reichsschuldbuch.

2. The Office for the Administration of the Fund of the Veterans of the Empire.

3. The Commission for the Imperial Debts, the Reichsschuldenkommission. This Commission, consisting of six representatives each of the Bundesrat and the Reichstag, and the President of the Rechnungshof, supervises the administration of the Imperial debts, as well as that of the active finances of the Empire, the war treasure, and the veterans' funds.

4. The Court of Financial Control, or the Rechnungshof. This court audits all bills of the Empire. It has absolute independence of the administration. Its officers are appointed

1 See page 14 I.

Central organizaation 


\section{GERMAN GOVERNMENT AND POLITICS}

for life and cannot be dismissed except for legal reasons.

The collection and administration of the Imperial revenues is left to the states, which are remunerated by the Empire for their services. The Empire exercises a general supervision over the state officers through Imperial commissioners, who belong to the Imperial Secretariat of Finances.

\section{SELECTED BIBLIOGRAPHY}

Howard, B. E. "The German Empire," Chap. XI (The Constitution and Imperial Finance).

Dawson, W. H. "The Evolution of Modern Germany," Chap. XX (The Price of Empire).

Barker, J. E. "Modern Germany," Chap. XXVI (The

Fiscal Policy of Germany and its Results). 


\section{CHAPTER XII}

\section{T H E A R M Y}

$\Delta S$ far as the military affairs of the German A states are centralized, they are administered by the Prussian Ministry of War. The necessary harmony between the Empire and the privileged states is brought about in the "Committee for the Army and the Fortresses" of the Bundesrat. The Prussian Ministry of War is divided into the General War Department, the Department for the Administration of the Army, the Department of Provision and Justice, the Inspection of the Supply of Horses, and the Department of Medical Affairs. Under the central organization is also the Feldzeugmeisterei (Inspection General of Ordnance), which has charge of the supervision and inspection of the technical institutions of the infantry, artillery and ammunition.

The local administrative offices of the Ministry of War are the Intendanturen (Army Commissariats) of which each army-corps has one. Each Intendantur is subdivided for purposes of more detailed inspection into Divisions Intendanturen. There are also special local Ammunition, Architectural, Garrison and Hospital Administrative offices.

The military institutions of Prussia are the 


\section{GERMAN GOVERNMENT AND POLITICS}

basis for the organization of the German army. The One of the greatest weaknesses of the German Confederation was the loose connection between of the the armed forces of the different states which formed the Confederation. The Constitution of the Empire did not entirely do away with the system of "contingent" armies; however, the harmony and centralization are so great, that outside of Germany the army appears as one, and it might justly be called an Imperial army. The most important part of the army, the Prussian part, and also that of Alsace-Lorraine, is by the nature of the Empire in the same hands in which is the supreme administration of the whole army. A similar situation has been created by special military treaties with most of the German states. Individual contingents with special privileges are now possessed only by Bavaria, Würtemberg and Saxony.

Articles 57-68 of the Constitution form the fundamental basis for the organization of the whole army. The expenses for the maintenance of the army are paid by the Empire. The strength of the army is fixed by the Imperial legislative bodies for a certain period. All legislation in regard to military affairs is Imperial. The commander-inchief of the army is the Kaiser. In time of peace he is somewhat restricted by special military treaties, but he has an unlimited authority during time of war. He has at any time the right of inspection and may declare a state of siege, mobi[ 150 ] 


\section{THE ARMY}

lize the army, appoint the higher officers, and also the lower officers in all states except Bavaria, Würtemberg and Saxony. The Princes of the different states, as well, have the right of inspecting their own contingents. In Bavaria the Kaiser has in times of peace no other right than that of inspection.

The Imperial Constitution gives a fixed number of soldiers in time of peace, but since 1874 it has been periodically increased. In July, I913, the peace strength of the army was, by Imperial law, raised to $66 \mathrm{I}, 478$ common soldiers or privates, 105,535 non-commissioned officers, 37,553 officers and military officials of higher rank, and about 20,000 one-year volunteers. This brings the peace strength up to about I per cent of the population, which was originally the numerical basis for the army, ${ }^{1}$ but which it has never had before. As soon as war breaks out, or is imminent, the army is increased by special mobilization ordered by the Kaiser. All means of communication are then placed at the disposition of the army. Germany is then in reality a "nation in arms."

As the unit of the peace formation of the army, Prussia-Germany has adopted the army-corps, of which there are, in time of peace, twenty-five (also one guard-mount division). This organization originated in the revolutionary wars of France, and was developed by Napoleon I. Prussia perfected it during the nineteenth century, and after

1 See R. V., Article 63. 


\section{GERMAN GOVERNMENT AND POLITICS}

the success of her armies in $1870-71$ it was adopted universally in Europe. ${ }^{1}$

A normal army-corps now consists, in time of peace, of (1) the Staff; (2) four brigades of infantry, two regiments of field artillery - comprising nine batteries of field guns, and three of field howitzers, seventy-two pieces altogether - three squadrons of cavalry, one or two companies of pioneers, a bridge train, and one or two bearer companies; (3) technical corps troops, one battalion of sharp-shooters (Jäger), telegraph troops, field hospitals, etc., one or two battalions of heavy field howitzers or mortars, and a machinegun group. The total fighting strength of the army-corps is about 30,000 in time of war. There is only one permanent cavalry division in peace, that of the guard, and this is divided into brigades. A brigade consists of two or three regiments of the same type of arms. The regiments of the heavy artillery, train, pioneers and infantry are subdivided into battalions, those of the cavalry into squadrons, and those of the field artillery into batteries. The army bill of 1913 provided also for five aeroplane battalions, or seventeen companies. There were further twenty-four dirigibles in the army in 1913.

1 There is now a tendency, however, to regard the Division as the unit of modern armies. This dates back to the end of the nineteenth century, when in most armies, including the German, the largest part of the field artillery was detached from the army-corps and placed under special command.

[ 152 ] 
The strategy and tactics of the army are in the hands of a central General Staff, the Grosse Generalstab. Besides this Great General Staff all the higher subdivisions have their General Staffs.

Military service in Germany is compulsory and universal. The system is due to the reform of the year 1808 in Prussia. The original idea Military service came from the revolutionary armies in France at the end of the eighteenth century, but Prussia systematized and perfected the idea, which later was adopted by all the other German states. Military service in Germany is an honor. Excluded from it are therefore all those who have been convicted of crimes. The members of ruling families, and a few privileged classes of the highest nobility are exempt; also the candidates for priesthood in the Roman Catholic church, and Heligolanders who were born before August II, I890. With these exceptions every able-bodied German is subject to military service from his seventeenth to his forty-fifth year.

As a rule, the qualified German belongs to the standing army from his twentieth to his twenty-eighth year. During the first two years - in the cavalry and field artillery three years he is permanently in service. The rest of the seven years he belongs to the reserve. During this time he is obliged to participate in two periods of military exercises, which lie two years apart, and must never amount to more than eight weeks. After the reserve-service follows the first Land- 


\section{GERMAN GOVERNMENT AND POLITICS}

wehr-service, extending over a period of five years. Until March 31 of the year in which his thirtyninth year is finished he belongs to the second Landwehr, and from then to the forty-fifth year to the Landsturm. All those troops which have done three years of permanent service belong only three years to the first Landwehr-service. The cavalry of the first Landwehr is not called upon for any service in times of peace; the other arms serve twice, from eight to fourteen days. Second landwehr and landsturm men are never called upon for actual service, except occasionally for.roll-call.

Any qualified German who emigrates or attempts to escape military service by untrue statements or self-mutilation is subject to punishment.

Besides these soldiers who do compulsory service there are "volunteers" who enlist at the age of eighteen for three years, or in the cavalry and field-artillery for four years. They are then made non-commissioned officers. At the end of a twelve-year service these non-commissioned officers are eligible for certain positions in the lower and middle civil service, and some appointments in the railroad, postal, police and church service are reserved to former non-commissioned officers who have passed the examinations.

In order to supply the officers of the reserve, especially for times of war, the system of oneyear volunteers exists in Germany. These men serve only one year, have the choice of their regi[ 154 ] 


\section{THE ARMY}

ment, and pay for their own rations, equipment, and quarters. At the end of their service, they may be elected non-commissioned officers and later on officers of the reserve by the corps of officers of their regiment. The privilege of doing only one year of permanent service is enjoyed by those who graduate from the middle division of the higher schools, or who pass an examination equivalent to this graduation. In general this graduation or examination may be compared with graduation from a high-school in the United. States. Besides these persons, all common-school teachers are entitled to the privilege of one-year service.

Officers of the army enter as common soldiers after graduation from a higher school, special cadet schools, or after passage of a special examination. After one year of service they are made second lieutenants, i.e., usually at the age of nineteen or twenty, and then they are promoted according to years of service and ability. Since the pay of an army officer is very low and his social obligations on the other hand are great, only sons of the wealthier class can afford to choose this career. The amount of salary and pension of commissioned and non-commissioned officers is laid down by law (July I 5, 1909) as in the case of civil service officers. ${ }^{1}$

All the members of the army and navy are subject to a special Military Criminal Law. The

1 See p. Irg. 


\section{GERMAN GOVERNMENT AND POLITICS}

non-contentious jurisdiction is also separately regulated for army and navy (Law of May 28, 1901), while with insignificant exceptions the civil law is the same for military and non-military people.

J. E. Barker, in his widely read book, "Modern

Why Germany needs a strong army Germany," explains the military nature of modern Germany from the history of its leading state, Prussia, which has given the whole Empire its character. "Prussia," he says, "like Rome, was founded by a band of needy and warlike adventurers. Both states were artificial creations, both could maintain themselves only by force of arms and extend their frontiers only by wars of aggression." 1

According to our opinion, Mr. Barker's statement serves the purpose for which he has written his book, i.e., to show to the world the detestable, dangerous character of the German state. However, from our knowledge of continental European history, we cannot agree with him. It would be difficult to find any sincere historian of Prussian history who would call the Hohenzollerns a "band of needy and warlike soldiers." The band of needy and warlike soldiers were the degenerated robber-knights, whom the Hohenzollerns forced to abandon their criminal life, thus restoring order out of the chaos in which the deplorable country had lain. Prussia was no more an artificial creation than other countries. Was

1 See Barker, J. E., "Modern Germany," Chapter XIII.

[ is6] 
not England created by the conquests of outsiders? Did not the colonists in the United States expel the Indians by force from their territory? As a matter of fact, hardly any state has come into existence without force. Prussia is not an exception. Neither does she differ from other states in the methods of extending her frontiers. What else than force did England mostly use to build up her tremendous colonial Empire? And Prussia did not always use the sword for the enlarging of her territory. Like other states, she acquired a part of it by family alliances and treaties of succession. To be sure, she frequently had to draw the sword in order to guard her rights in this respect.

The third part of Mr. Barker's statement, however, is true. Prussia-Germany, like any other nation, and more than they, could maintain herself only by force of arms. Several times Germany has had sad experiences which have taught her sound lessons in military preparedness. Her military weakness and geographical situation made her the battle-ground for all Europe. The experiences of the horrible Thirty Years' War especially, led the Great Elector to the creation of a standing army in BrandenburgPrussia, the basis for Germany's future army. If Prussia earlier had had the army which she possessed at the death of the Great Elector, she would not have had suffered so terribly in the Thirty Years' War. And on the other hand, 


\section{GERMAN GOVERNMENT AND POLITICS}

without this army increased and superbly trained by Frederick William I, his great son, Frederick II, would have suffered defeat and diminution of territory by the united powers of continental Europe.

Germany is unfortunately situated in the middle of Europe, surrounded by partly unfriendly nations. Its frontiers are 4,570 miles in extent. Only the northern and southeastern borders are protected by nature, i.e., by the ocean and high mountains. The most dangerous border lines in the east and west are entirely unprotected. Purely for defensive purposes Germany needs a strong army.

But Germany is no longer satisfied merely to exist. She has become a great European power, a world power. The time has passed when the Germans were nothing but a people of thinkers and poets, when therefore their territory was the air; when "other nations admired the Germans and at the same time smilingly took possession of the earth. Germany now demands a place in the sun for her millions of industrious, hardworking people; she demands an open door in foreign countries for her prosperous industry and commerce. Her diplomacy cannot restrict itself for the future purely to defense. It must watch events in the whole world and be able to speak a strong word whenever her interests are endangered. But every word in diplomacy which cannot be realized, if necessary, is a ridiculous joke.

[ I 58 ] 
A strong army is the back-bone of any efficient diplomacy.

Modern Germany, with the greatest army in the world, has been the most peaceful country in the world. Since the birth of the Empire up to the present war, she had never experienced a war. But less than any other state can Germany permit herself the dangerous luxury of playing with anti-militarism and ideas of eternal peace while other countries are armed. Germany needs a strong army for her proper defense and safeguard and for her maintenance as a leading nation of the world.

\section{SELECTED BIBLIOGRAPHY}

Howard, B. E. "The German Empire," Chap. XII (The Armed Forces of the Empire).

Veritas. "The German Empire of Today," Chapter IV (The Army and Navy).

Barker, J. E. "Modern Germany," Chapter XIII (The Army and Navy of Germany). 


\section{CHAPTER XIII}

THE NA VY OF THE EMPIRE

CHE navy of Germany is unlike her army, 1 being wholly a unified Imperial institution. Central In peace and war the Kaiser is the commandertion in-chief. $\mathrm{He}$ alone has the right of inspection and of appointment to office. ${ }^{1}$

After the foundation of the German Empire, in $187 \mathrm{r}$, Lieutenant-General von Stoch was made commanding admiral. In 1883 he was succeeded by Lieutenant-General von Caprivi. In 1889 the highest command of the navy was for the first time given to a naval officer, Admiral Count Monts. In 1889 the Kaiser himself assumed the highest command of the navy. Under him are: the chief of the general staff of the navy; the chiefs of the two naval stations, Baltic and North Sea; the chiefs of the different squadrons; and the inspector of the training department.

The central office for the administration of the navy is the Reichsmarineamt or Imperial Naval Office. At the head is a Secretary of State, who is responsible to the Chancellor, although in reality he enjoys a great amount of independence. This seems to be due to the personality and [ 160 ] 1 Cf. R. V., Article 53. 
talent of the present Secretary, Grand-Admiral von Tirpitz, who was appointed Secretary of State for the Navy in 1897 , and has since then been permanently in office, enjoying the highest confidence of the Kaiser, the Reichstag and the German people.

Under the direct supervision of the Naval Office are the three Imperial docks of Danzig, Kiel and Wilhelmshafen, the artillery and torpedo depots, the provision stations at Kiel and Wilhelmshafen, the sanitation offices, the observatories in Hamburg, Wilhelmshafen, and Kiel, the judicial department, the chaplains, and the government of Kiao-chau in Asia. ${ }^{1}$

In the spring of 1914 the German navy consisted of thirty-three battleships, thirteen large or armored cruisers, thirty-nine small cruisers, seventy small and one hundred and forty-nine large torpedo boats, twenty-eight submarine boats, six armored coast defenders, eleven gunboats, three small gunboats, thirteen training vessels, and thirteen vessels for special purposes.

The main naval centers of Germany are Kiel, Wilhelmshafen, and Heligoland. Those of Danzig, Swinemünde and Lübeck are of little importance. Besides the government docks mentioned before, there are private docks in Danzig, Stet-

1 We find an analogy to the administration of a dependency by the Naval Office in the American dependencies of Tutuila and Guam, which are administered by the navy. 


\section{GERMAN GOVERNMENT AND POLITICS}

tin, Hamburg, Kiel and Bremen. These employ three times as many workingmen as the government yards.

The navy is recruited like the army, the seafaring class being compelled to serve in the navy. There are three years of active service, four years in the first reserve and five years in the second reserve. Volunteers are accepted as in the army, but men without previous sea experience must enlist for at least four years. Aspirants for the career of naval officer usually graduate from a higher school of learning, serve one year as cadets and two and a half years as ensigns before they are promoted to lieutenant. Promotion follows the passage of rigid examinations. In all other regards the conditions in the navy are analogous to those of the army.

When the German government began to up-

Why Germany needs an adequate navy build her navy the general idea met with comparatively little opposition in the Reichstag. Such opposition as there was has gradually decreased with the growth of the Empire as a world power, the enlightenment of the general public by the government and the Navy Society, and the clever parliamentary tactics displayed by the naval department in handling the question.

Naturally, Germany found the bitterest opposition abroad and especially in Great Britain, who saw her absolute rule of the ocean endangered by the rapid development of the German navy. She was afraid that Germany would in a short time [r62] 


\section{THE NAVY}

be a most dangerous rival. And she' was right, for Germany takes now the second place as a naval power. That there are a few over-ambitious Germans who would like to see their fatherland have the strongest navy, as she posseses the strongest army, cannot be denied. But the majority of the German people, the intellectual and political leaders, have always denied that they are striving for the hegemony of the ocean. The responsible representatives of the German government have again and again declared in the Reichstag that Germany does not care to outdo England in her armaments on the sea, that she is only building up an adequate navy for the maintenance of the German nation as a factor in the politics of the world.

The passage in the preamble of the first great navy bill (1900) which alarmed British opinion, "Germany's naval strength should be such, that even the greatest sea power must hesitate to attack Germany unless she is willing to risk her whole position as a Great Power," is, if correctly analyzed, the statement of a defensive policy. But from this purely defensive instrument the German navy developed naturally to an organ with much broader aims.

On July 3, I900, the German Kaiser gave the keynote for Germany's necessity of building a strong navy when he said: "The wave-beat knocks powerfully at our national gates, and calls us as a great nation to maintain our place 


\section{GERMAN GOVERNMENT AND POLITICS}

in the world - in other words, to follow worldpolicy. The ocean is indispensable for Germany's greatness, but the ocean also reminds us that neither on it nor across it in the distance can any great decision be again consummated without Germany and the German Kaiser." "World power and sea power are complementary; the one cannot exist without the other."

Another important reason for the construction of the navy is the tremendous growth of industry and commerce of the German Empire since its foundation. A few figures will make this progress clear. In 1870 the capital of iron shipbuilding yards was $4,800,000$ marks; in the year I910 it had reached $105,890,000$ marks. Since the foundation of the Empire the merchant marine has increased about thirty fold. While in the seventies the German merchant ships were second rate vessels, they are today the largest and best of steamers afloat. The shipping of the Empire has increased from seven billions of marks in 1900 to thirteen in 1912, while its land commerce has increased from about three and three quarters to six and a half billions of marks. Imports amounted in 1900 to $6,043.0$ million marks, in 1912 to $10,691.4$ million marks. Exports were represented in 1900 by $4,752.6$ million marks, in I 912 by $8,956.8$ million marks.

German industry and commerce represent an enormous investment. Every sensible merchant insures his business in proportion to its value.

[ 164 ] 
The expenses for the Imperial navy are like the premium of an insurance policy. The government and the people of Germany act like cautious merchants spending a large amount of money for their insurance, i.e., the battle fleet.

Still other reasons compel Germany to keep up a strong navy. No country aside from Great Britain has so many of her subjects living in all parts of the world. Whenever in former times they were in distress and danger, they were without the help and assistance of their government. Without a fleet the Empire was nearly powerless, and robber governments, of the type of Haiti, could commit theft and crimes against German citizens without being punished. A great state like Germany owes it to its authority, prestige and interests that its citizens be protected in any part of the world where they carry on their business in a legitimate way.

Finally, Germany needs an adequate navy because of her colonial possessions. Colonies without a navy are an impossibility, as history has often proved. The Germans learned this from their own earliest colonial experiences in Venezuela and Africa. Without a fleet they would lose their colonies immediately in case of war with any naval power. As small as the German fleet was until a few years ago, it helped considerably in gaining and holding the German colonies acquired in the eighties. Speed is one of the fundamental requirements in 


\section{GERMAN GOVERNMENT AND POLITICS}

the suppression of a revolt of natives. Naturally the navy renders the quickest service in such cases.

\section{SELECTED BIBLIOGRAPHY}

Hurd, A. and Castle, A. "The German Sea Power: Its Rise, Progress and Economic Basis."

Barker, J. E. "Modern Germany," Chapters XIII-XV.

Veritas, "The German Empire of Today," Chapter IV (The Army and Navy).

Howard, B. E. "The German Empire," Chapter XII (The Armed Forces of the Empire). 


\section{CHAPTER XIV}

RAILROADS, CANALS, POSTSA D T E L E G R A P H S

NE of the main reasons for the economic prosperity of the German Empire is its excellent traffic policy, which is another example of the thoroughness, efficiency and far-sightedness of the German government.

When the North German Federation was founded, the several states had governmental Rallroads authority over all the railroads in their territory. The Constitution of the Federation and of its successor, the Empire, did not deprive them of these rights. ${ }^{1}$

The Constitution of the Empire, Article 4, Section 8 , recognized the competence of the Union to legislate and exercise general supervision with regard to railroads, but as yet no general Imperial law has been passed under this section. However, for military reasons and to improve general traffic conditions greater harmony has been brought about between the administration of railroads in the several states. Until an Im-

${ }^{1}$ For this reason the very interesting investigation of the result of government ownership of railroads in the German states will be discussed in a subsequent volume in this series on the government of the several German states. 


\section{GERMAN GOVERNMENT AND POLITICS}

perial law is passed, the provisions of Articles 4I-47 of the Constitution create a temporary organization of the railroads of the Empire. These provisions require the individual states to exercise their rights in a uniform way. The Empire has for military purposes the right to build railroads in any state and to connect Imperial railroads with those of the states. The control of the railroad rates is exercised by the Bundesrat. ${ }^{1}$ It has also the right to issue ordinances regulating the detailed administration of railroads. For the enforcement of the rules laid down in the Constitution, and of the administrative ordinances of the Bundesrat, the Reichseisenbahnamt (Imperial Railroad Office) was created in $1873 .^{2}$

Some railroads in Alsace-Lorraine and in Luxemberg are owned by the Empire. These have their central organization in the Reichsamt für die Verwaltung der Reichseisenbahnen (Imperial Office for the Administration of Imperial Railroads). The head of this office is the Prussian Minister of Public Works. Under him, in Alsace-Lorraine, is a general office of the Imperial railroads, with its seat in Strassburg.

1 The Bundesrat has regulated railroad rates by an ordinance, the Verkehrs-Ordnung für die Eisenbahnen Deutschlands, November 15,1892 .

2 The functions of this office and that of the Bundesrat in this connection may be well compared with those of railroad commissions in the United States of America.

[ I68] 
RAILROADS, POSTS AND TELEGRAPHS

An idea of the recent development of German railroads is given by the following statistics: ${ }^{1}$

\begin{tabular}{l|r|r|r}
\hline $\begin{array}{r}\text { Railways of Standard Gauge in } \\
\text { Germany }\end{array}$ & $\mathbf{1 8 8 5}$ & I9I1 & $\begin{array}{r}\text { Increase } \\
\text { in } \\
\text { per cent }\end{array}$ \\
\hline & & & \\
Length of railways in km.......... & 37,190 & 59,763 & 60.7 \\
Capital invested (million mks.) .... & 9,722 & 17,833 & 83.4 \\
Gross receipts (million mks.) ....... & 997 & 3,271 & 218.0 \\
Goods carried (in million ton km.) & 16,600 & 61,870 & 272.7 \\
Persons carried I km. (in millions) & 7,932 & 37,855 & 377.1 \\
& & & \\
\hline
\end{tabular}

\section{Comparative Railway Development}

(A) Length of Railways in Operation in $\mathrm{km}$.

\begin{tabular}{l|r|r|c}
\hline & I890 & I9II & $\begin{array}{c}\text { Per cent of } \\
\text { increase }\end{array}$ \\
\hline I. Germany ....... & 42,869 & 61,936 & 42.6 \\
2. England ....... & 32,297 & 37,649 & 16.4 \\
3. United States... & 268,409 & 396,860 & 44.6 \\
\hline
\end{tabular}

(B) Length of Railways per $100 \mathrm{sq} . \mathrm{km}$. of area

\begin{tabular}{l|r|r}
\hline & 1890 & I9I I \\
\hline I. Germany ........ & 7.9 & 11.4 \\
2. England ....... & 10.3 & 12.0 \\
3. United States .... & 3.0 & 4.3 \\
\hline
\end{tabular}

1 Taken from K. Helfferich, "Germany's Economic Progress and National Wealth, 1888-1913," pp. 70-71. 


\section{GERMAN GOVERNMENT AND POLITICS}

Of the total length of German railways in 19I3, only $2,926 \mathrm{~km}$. were privately owned.

The importance of natural and artificial water-

Inland waterways and canals ways as a means of cheap transportation, especially for bulky goods, such as coal, wood, grain, etc., had been early recognized by the governments of some German states, especially Brandenburg-Prussia, but the development which has given Germany a prominent place in this regard, occurred in the modern German Empire. Almost all the large rivers of Germany run from south to north, and a connection of them east and west by waterway had to be effected by means of canals. Frederick William, the Great Elector, built the first canal, named after him, which connected the Oder with the Spree, and by doing this had splendid success in diverting considerable trade from Stettin, at that time a Swedish possession. Frederick the Great had the Havel-Elbe (Plauensche) Canal, the Havel-Oder (Finow) Canal, and the Elbe-Oder-Weichsel (Bromberg) Canal built, altogether $180 \mathrm{~km}$. of waterway. After the construction of railroads began, the waterways were for a long time neglected as useless and antiquated. It was not until after the foundation of the North German Federation that interest in river regulation and canals was reawakened. Between I 890 and I900 four important canals were built, and in spite of the opposition of the influential Agrarian Party the system of canals was steadily developed. At the present time the Rhine is al[ 170 ] 


\section{RAILROADS, POSTS AND TELEGRAPHS}

most completely joined with the Oder, thus connecting the eastern regions of Prussia with the North Sea and world-commerce. The greatest project, which is now almost carried out, is the Midland Canal, a connection of the Rhine, Weser and Elbe. It runs from Ruhrort to Dortmund, where it is taken up by the Dortmund-Ems Canal, reaches the Weser at Minden, crosses the river Leine at Hanover and empties into the Elbe near Magdeburg. This great canal is of the utmost importance for the distribution of coal from Germany's largest coal field to the industrial centers and the North Sea. The diverting of commerce from Holland and directing it to German sea-ports, which had been hoped for with the construction of the Dortmund-Ems Canal, has not been accomplished, since it cannot be used by the larger Rhine vessels.

Some other canals of importance are the Elbe-Trave Canal, which connects Lübeck with the Elbe; the Oberländische Canal, a waterway connecting the large East Prussian lakes with the Baltic Sea; the Klodnitz Canal, connecting the Silesian industrial center with the Oder and indirectly with Berlin; and the Saar Canal, connecting the coal mines of the Saar with the Moselle.

The most important of all German canals however is the Kaiser Wilhelm or North-East-Sea Canal. It begins at Brunsbüttel, north of the 


\section{GERMAN GOVERNMENT AND POLITICS}

mouth of the Elbe, flows through Holstein and ends in the bay of Kiel, thus connecting the Baltic and North Seas and avoiding the long and dangerous trip around the peninsula of Jütland. Its length is $6 \mathrm{I}$ miles; it can be used by the greatest ships and is wide enough for two large ships to pass. This canal is of the utmost importance for military purposes. It goes without saying that the ends of the canal are strongly fortified. Within sixteen hours the German men-of-war can be transferred from Kiel to the bay of Heligoland. If the German navy chooses, it can in case of war select a perfectly safe location in the Baltic Sea. The Kiel Canal actually saves Germany a fleet of battleships.

The oldest projects of digging a canal through Holstein go back to the fourteenth century. The construction of the present canal was decided upon by the Bundesrat and Reichstag in 1886 . In 1895 the canal was opened by Kaiser William II and named after his grandfather. In the year 1914 an enlargement and improvement of the canal was completed, making it passable by the modern type of dreadnought.

In relation to waterways, we should recall the great amount of work and money spent by the German government to regulate rivers in order to make them useful for navigation. Mr. Barker, is right when he says: "If it were not for the existence of the German waterways, the German 
industries would certainly not be in the flourishing condition in which they are." 1

The first systematic organization of the postal service in Germany was that of the counts of Turn and Taxis, who received the exclusive and heriditary privilege of postal delivery for the Holy Roman Empire in the year 1615. Very gradually, in the course of centuries, private

The Imperial post, telegraph and telephone service postal service came under state control.

The Constitution of the German Empire established complete Imperial ownership of posts, telegraphs and telephones (Articles 4, IO and Article 48), except for Bavaria and Würtemberg. The supreme head of the postal service is the Kaiser. $\mathrm{He}$ issues ordinances and instructions regulating the administration of posts, telegraphs and telephones without interference of the Bundesrat, makes treaties with other states concerning postal affairs, ${ }^{2}$ and appoints all higher and supervising officers. Subordinate officers may be appointed by the rulers of the states in which their service is rendered. As a matter of fact very few states exercise these rights, most of them having ceded their privileges to the Kaiser. All officers of the postal service are

${ }^{1}$ Barker, J. E., "Modern Germany," p. 420 . Americans would do well to investigate the canal question of Germany more thoroughly, as great tasks are waiting for them in this field.

2 E.g., the treaties in regard to the "International Postal Union," which was founded at the suggestion of the first German Postmaster-General, Stephan. 


\section{GERMAN GOVERNMENT AND POLITICS}

subject to the Imperial civil service law. The income and expenditure on account of the postal service belong to the Empire, except in Bavaria and Würtemberg. These states have also the privilege, within certain limitations, of making special postal treaties with all their neighborstates.

The post, telegraph and telephone services of the German Empire rest upon the following general principles. They are conducted primarily for the common public welfare, only secondarily for profit. Offices must therefore be established in any case of need, regardless of the financial return. Everybody is equally entitled to their use. The same rules, the same tariff exist for all. The officers, subject to severe penalties, are obliged to maintain the so-called "secrecy of letters and telegrams." Corresponding to these duties the postal department is entitled to certain privileges. The state has an absolute monopoly in the mail service of sealed letters and political papers, published more than once a week. Open letters and packages may be forwarded by private persons or corporations. The state has also, with a few important exceptions, a monopoly of telegraphs and telephones.

A special Imperial law of 1875 regulates the services which the railroads perform for the post, as time tables, offices in railway stations, free transportation of all mail and the officers acompanying it, etc. In case of disputes between the [ I74] 


\section{RAILROADS, POSTS AND TELEGRAPHS}

postal service and the railroads the Bundesrat has the first and final decision.

The business of the post includes the transportation of letters, cards, printed matter, merchandise and small packages, the issue of money orders, checks and discounts, and, in some remote parts, the transportation of persons. The fees for the service of postal, telegraph and telephone institutions are fixed by Imperial law, regulations of the Chancellor with the consent of the Bundesrat, or by international treaties.

The central organization of the post, telegraph and telephone service in Germany is the Imperial Post Office, the Reichspostamt, at the head of which is a Secretary of State. Under this central office there are forty-one supervising local offices, the Oberpostdirektionen, and a large number of different types of lower post offices.

\section{SELECTED BIBLIOGRAPHY}

Barker, J. E. “Modern Germany," Chapter XVII (Waterways and Canals); Chapter XVIII (The Railroads and Railway Policy of Germany).

Veritas, "The German Empire of Today," Chapter VI (Traffic Policy).

Dawson, W. H. "The Evolution of Modern Germany,"

Chapter XI (Railways and Canals). 


\section{CHAPTER XV}

THE GOVERNMENT OF

A L S A C E - L O R R A I N E

$\triangle$ GAIN and again we hear and read that 11 Germany deprived France of truly French History, territory and population when she took Alsace and populathon and a part of Lorraine away from her in $187 \mathrm{I}$. This statement demands careful examination. Since the division of Charlemagne's great Empire, i.e., since 843 , these provinces belonged to the Holy Roman Empire. They were inhabited by German people and their civilization was Germanic. As a consequence of the Thirty Years' War the dismembered and completely powerless German Empire was forced to deliver the larger part of these provinces to France. Strassburg and its environment was seized by Louis XIV in $168 \mathrm{I}$ in the midst of peace. Thus Alsace and Lorraine were lost through the internal weakness and military unpreparedness of the Holy Roman Empire. For more than a hundred years the annexed provinces, especially Alsace, remained completely German in civilization, language and general character. When the great wave of revolutionary enthusiasm, social, economic and political, swept all over France and western Germany, the inhabitants of Alsace-Lorraine began

[ 176$]$ 
to become attached to the political spirit of France, as indeed did all southern Germany. More and more they were alienated from their original mother-country, but only politically. Essentially, in their character and soul, they remained Germanic. Germany had never forgotten her claims to these provinces, but not until $\mathbf{1} 87 \mathbf{I}$ could they be realized. Then Lorraine had become so impressed by French influence that Bismarck, who was above all a nationalist in his policy, hesitated to retake Lorraine from France. However, he was finally persuaded by Moltke, who insisted on taking the strong fortress of Metz, which, as he said, would save the new Empire 100,000 soldiers. The territory ceded by France as fixed by the preliminary peace-treaty of Versailles consisted of 145,1 1 2,6 I 4 square kilometers. By special agreement, all French subjects living in the reconquered provinces had until October I, 1872 , the choice of emigration and renouncing their German citizenship. Some of the inhabitants took advantage of this option, but most remained, although their sympathies were in the majority at that time with France. From 1875 to 1895 the increase of the population in AlsaceLorraine was 18.4 per cent, that of France only 6.4 per cent. There was no conspicuous emigration to foreign countries after the seventies. The progress of the two provinces, materially as well as intellectually, went hand in hand with that of the Empire. Slowly but steadily the German 


\section{GERMAN GOVERNMENT AND POLITICS}

population belonging to the Alemannian tribe, was again feeling itself to be German.1

The strongest opposition is directed against Prussian bureaucracy, discipline and so-called militarism. But we must remember that this opposition is also found to a great extent in southern Germany. The Zabern affair, greatly exaggerated by the French and foreign press, was an isolated incident. When we consider that it took France a hundred years to see the first success of her Gallicizing policy and two hundred years to secure the sympathy of the large majority of the population, the German government may be well satisfied with the success of its work of forty years.

During the Franco-German war, Alsace-Lor-

Development to 1911 raine was ruled by a military governor. On June 9, I87I, it was united by an Imperial law with the Empire as one of her provinces. From that time until June 25, 1873, it was governed by the Chancellor and a committee of the Bundesrat and an Oberpräsident, entirely as an administrative domain of the Empire.

The first step toward self-government in Alsace-Lorraine was taken May 2, 1877, when a special legislative body, the Landesausschuss, was created.

The next step toward a more extensive selfgovernment and autonomy was made July 4,

1 In 1910 the population speaking German numbered I,634,260; French 204,262.

[ 178 ] 
I879. ${ }^{1}$ According to this new arrangement Alsace-Lorraine continued to be an Imperial province, or Reichsland. A Statthalter (Governor) was appointed by the Kaiser as the head of the government, and was entirely independent of the Chancellor. The Statthalter was thus the personal representative of the Kaiser, and directly responsible to him. He was assisted by a Ministry, Landesministerium, with a Secretary of State, the Staatssekretär, at its head, all appointed by the Statthalter. In addition, a Council of State (Staatsrat), served as an advisory body. It consisted of the Statthalter as presiding officer, the Secretary of State, the Under-Secretaries, the President of the Oberlandesgericht, the Attorney General, and eight to twelve members appointed by the Kaiser for three years, of whom three were nominated by the Landesausschuss. The Landesausschuss or legislative body consisted of fifty-eight members, elected by indirect vote, thirty-four from the Assemblies of the Districts, ${ }^{2}$ twenty from the Assemblies of the Country Circles, ${ }^{2}$ four from the cities of Strassburg, Mühlhausen, Metz and Colmar. Laws for AlsaceLorraine were passed either in the same manner as laws for the whole Empire or by the Bundesrat and Landesausschuss with the sanction of the Kaiser and countersigned by the Statthalter, not

1 The "Reichs-Gesetz betreffend die Verfassung und Verwaltung Elsass-Lothringens."

2 Subdivisions for purposes of local government. 


\section{GERMAN GOVERNMENT AND POLITICS}

the Chancellor. They were required to be published in a special official paper for Alsace-Lorraine, the "Gesetzblatt für Elsass-Lothringen."

The desire of the people of Alsace-Lorraine is

The present status to become a state like the other twenty-five states of the Union. They desire the same rights as the other German citizens. The government has feared undue French influence and hesitated to grant further self-government. Recently, however, it was led to think that the moment for further development toward statehood had come, although it still objected to absolute autonomy. The proposals of the government, introduced December 17, 1911, were referred by the Reichstag to a special committee. The propositions of this committee the government declined to assume, since they gave Alsace-Lorraine too much power. On May 19 a compromise was presented to the Reichstag, and passed a week later.

According to this plan Alsace-Lorraine is still, in spite of the declaration of the statute, a province of the Empire. The Governorship remains as it was. The Governor instructs the three members of the Bundesrat who were given to AlsaceLorraine, and since he depends on the Kaiser, the latter really controls them. Their votes are not counted in favor of Prussia unless Prussia could obtain a majority without such votes, and are not to be counted upon proposals of amendments to the Constitution.

[180] 


\section{GOVERNMENT OF ALSACE-LORRAINE}

Laws for Alsace-Lorraine are to be made by a Landtag, consisting of two houses. The upper house is composed of thirty-six members, one half nominated by the Bundesrat and appointed by the Kaiser; others are members by virtue of holding certain offices; eleven are elected by the municipal, commercial and industrial bodies. The term of office is five years. The lower house has sixty members elected for five years by secret ballot, based on universal suffrage. The rules and regulations for the lower chamber as well as the position of its members are modeled after those of the Reichstag. Laws for Alsace-Lorraine are made by these two chambers and sanctioned by the Kaiser, who has an absolute veto.

For the purpose of local government, AlsaceLorraine is divided into three Districts: Unterelsass, Oberelsass and Lothringen. These are subdivided into circles and communes. The canton, a subdivision of the circle, is of little meaning. It serves especially as a notariate district.

The recent change of the government in AlsaceLorraine is certainly a great step toward absolute statehood. Doubtless, as has been officially expressed, it is not the end of such a development. It is the desire of the German people as a whole, and of the government, to give Alsace-Lorraine full statehood; the only difference consists in the speed with which it should be done. In opposition to the Center and Left the Conservative 


\section{GERMAN GOVERNMENT AND POLITICS}

groups and National-Liberals, as well as the government, are in favor of a slow organic development, especially as long as there still exists an influential French party, not yet reconciled to the conditions created by the peace of 1871 . The greatest difficulty is with regard to the form of government Alsace-Loraine should have. General harmony requires, especially as a border state against the Republic of France, that it should be made a monarchy, with a strong patriotic monarchical house. But who should be the monarch? The moment must be waited for patiently when an opportunity shall offer to solve the problem.

\section{SELECTED BIBLIOGRAPHY}

Howard, B. E. “The German Empire," Chapter X (AlsaceLorraine and its Relation to the Empire). Jordan, D. S. "Alsace-Lorraine: A Study in Conquest." 


\section{CHAPTER XVI}

THE JUDICIAL SYSTEM OF THE GERMA N EMPIRE $\mathrm{P}$ to January $\mathrm{I}, 1900$, there existed in The cirll
Germany an antiquated and confused code situation in regard to the civil law.

In Prussia three different civil codes were in force: the Allgemeine Landrecht of 1794 in the old Prussian territories of 1815, the Gemeine Deutsche Recht, a mixture of Roman, Germanic and canon law; elsewhere and in the territory west of the Rhine the French Civil Code (Code Napoléon). Baden had her Landrecht, derived mainly from the French Civil Code; the Kingdom of Saxony its own code of 1863 ; Schleswig-Holstein the Danish law of Christian V of 1863 . A small portion of Bavaria was under the Austrian Code of $18 \mathrm{II}$; while the largest single territory, i.e., central Germany, was under the Roman law as received in the middle ages. All these laws were modified by local custom, so that different law was administered in the same political jurisdiction and even in the same city.

Long before the foundation of the new German Empire this confusion had awakened desires for unity and reform, but before the political union 


\section{GERMAN GOVERNMENT AND POLITICS}

of Germany no attempt had succeeded. The history of the German Civil Code is the history of German political unity.

The movement for legal unity began immediately after the Napoleonic wars. In the year I814 a German professor of jurisprudence, Thibaut, wrote: "I am of the opinion, that our law ... needs a complete and quick change, and that the Germans cannot be content in their civil relations unless all German governments try to bring into effect with united strength the publication of a code for all Germany."

Thibaut, the patriotic politician, was opposed by the famous founder of the historical school of law, Savigny, who denied the necessity as well as the possibility of creating a common code for Germany at that time. He expected a unity of law to result from the very gradual organic development of the science of jurisprudence. The universities were, in his opinion, the force that would eventually produce a common German law.

The German Confederation did not pay any attention to Thibaut's suggestions and was hardly in an appropriate state to take up the unification of the German law since it had no general legislative power, ${ }^{1}$ but how deeply the

1 The project for an Imperial Constitution of 1849 provided in Article XIII, Section 59, for a common code in civil and criminal law and procedure, in bills of exchange and commercial law.

[ 184$]$ 
necessity for a common law of Germany was felt, can be seen by the repeated attempts to create common codes even under these imperfect conditions. In fact two attempts, led to practical results. In 1847 a Code on Bills of Exchange, and in 1859 a Commercial Code, went into effect for the whole Confederation. The draft of a Code of Contracts, prepared without the participation of Prussia, was never enacted, since the Austro-Prussian war of 1866 broke out on the very day it was finished. The idea of a common German law had now gained a number of warm friends, and under the North German Federation codification was extended to criminal law and legal procedure.

In the year 1873 a bill, introduced by deputy Lasker in the Reichstag, was passed to amend the Constitution so as to include within the competence of the Empire the whole civil law. The Bundesrat then appointed a preliminary code commission of five prominent practical jurists and later a general commission of eleven members who were leading professors of jurisprudence and judges, specialists in the different law systems of that time. The drafting of the different parts of the Civil Code was given to five members as redactors. After seven years of individual work the commission came together and discussed the drafts. In the year 1887 the project was transmitted to the Chancellor and published by him in 1888 , together with a summary of the 


\section{GERMAN GOVERNMENT AND POLITICS}

existing situation and reasons for the changes recommended by the commission.

The purpose of this publication was to procure suggestions and criticisms from all sources. Indeed the literature produced was most extensive. The strongest opposition came from the Germanistic school led by the distinguished Professor Gierke of Berlin, who wished a fuller recognition of German customary law. As a result of those criticisms, a new commission of twenty-two members, representing all interests in the Empire, was appointed. Each draft of the Code was published and after the criticism of the public, thoroughly revised by the second commission.

In January, I895, the draft of the Code and the Introductory Law were completed and placed on the table of the Reichstag. Here the project, after the first reading, was transmitted to a committee of twenty-one members from the different parties. In June the committee reported to the House. July I, 1896 , the bill was passed by a very large majority with only one amendment. The Bundesrat adopted the Code (Bürgerliches Gesetzbuch, officially abbreviated B. G. B.) on July 4, and it was published on August I 8, I 896. It went into effect January I, I 900, together with an Introductory Law, Law of Judicial Organization and Law of Civil Procedure.

The making of the German Civil Code is perhaps the most remarkable example of brilliant, [ 186 ] 


\section{JUDICIAL SYSTEM OF THE EMPIRE}

thorough, constructive legislation rendered possible by the idealism of the mass of the German people and by their patience and confidence in their jurists. It was the work of aristocrats in education guided by the public opinion of their fatherland. It offers, as an English writer observes, ${ }^{1}$ a standing object-lesson to all states that are looking forward to a scheme of codification, and the Germans may well be proud of the labors which for twenty-two years were devoted to its consideration.

The German Civil Code is generally recognized by foreign jurists as a masterpiece in jurispru-

Outline of the civil code dence if not as the greatest code since Justinian. Thus Professor Maitland, the emiment English jurist, says: " "The German people have brought that law (i.e., the Civil Code) up to date, and are facing modern times with modern ideas, modern machinery, modern weapons." "It is the most carefully considered statement of a nation's laws that the world has ever seen." 3 And E. M. Borchard, an American specialist on German law, uses the following words: "German codification truly exemplifies a power of legal expression with which Bryce credits the Roman jurists - the power of so framing general rules as to

${ }^{1}$ A. P. Higgins, "The Making of the German Civil Code."

2 "Independent Review," I906, p. 219.

${ }^{3}$ Maitland in the introduction to his translation of Gierke's "Political Theories of the Middle Ages." 


\section{GERMAN GOVERNMENT AND POLITICS}

make them the expression of legal principles, and of working out these rules into their details so as to keep the details in harmony with the principles." 1

The 2,385 paragraphs of the Code are grouped into five books, of which the first (Allgemeiner Teil, I-240) contains general principles while the second book deals with the "law of obligations" (Recht der Schuldverhältnisse, 24I-304), the third with the "law of things" (Sachenrecht, 854-I,296), the fourth with the "family law" (Familienrecht, 1,297-1,92I), the fifth with the "law of inheritance" (Erbrecht, 1,9222,385).

This classification, peculiar as it might seem to Anglo-Saxon jurists, ${ }^{2}$ is based upon the arrangement of the older German systematic treatises on the Germanized Roman law and was therefore familiar to the German lawyers and judges.

In order to harmonize state law with the Imperial civil law, to make transitory provisions and to regulate the matters left to the legislation of the several states, these states passed Ausfübrungsgesetze or "Executive Acts to the Civil Code."

Criminal law.
When the German Civil Code went into effect a unified criminal law had already been secured

${ }^{1}$ E. M. Borchard, "Guide to the Law and Legal Literature of Germany."

${ }^{2}$ See E. J. Schuster, "The Principles of German Civil Law."

[ I88 ] 


\section{JUDICIAL SYSTEM OF THE EMPIRE}

which dates from May 31, 1870. Since that time legislation of the several states in the control of crime has been restricted to violations of regulations concerning taxes, fishing, hunting, forestry and mining.

The Criminal Code of the German Empire ${ }^{1}$ is divided into two parts, one containing the general principles and the other the particular punishable crimes.

Subject to punishment under this criminal law are all persons, citizens and foreigners living in Germany. German citizens may be punished also for certain crimes committed abroad, e.g., treason, crimes of laesae majestatis, and crimes committed in official service.

Only the completed act is punished to the full extent. An attempted crime is punished, but more mildly. Partners and instigators of a crime are punished as fully as the one who committed the crime. Those who assisted receive a milder punishment.

Persons who are insane, or who act in selfdefense, or children up to twelve years are not punished. The latter, however, are subject to a special corrective education under official supervision. Youthful criminals between twelve and eighteen years are punished very mildly, and their cases are now usually brought before

1 It might be mentioned that a new criminal code is being prepared, but that its preparation will probably continue for several years. 


\section{GERMAN GOVERNMENT AND POLITICS}

a special court similar to the American juvenile courts.

The public prosecutors are obliged to bring before a court every criminal offender of whom they have evidence, except in a few cases of minor crimes, where the direct interest of the state is not involved. In these instances the prosecutor takes a case up only if it is brought before the court by the party concerned.

A crime cannot be punished if a certain time has elapsed since it was committed. Unimportant torts come under the statute of limitation after three months, severer crimes after three to twenty years.

Criminal acts are divided into three classes: $V$ erbrechen or felonies, Vergehen or misdemeanors and $\ddot{U}$ bertretungen or trespasses. A felony is an act punishable by death or service in penitentiary or fortress for more than five years. A misdemeanor is punishable by fortress imprisonment for less than five years, by prison or fine of more than 150 marks. A trespass is punishable by arrest or fine of less than 150 marks.

Capital punishment is executed by decapitation. Thus are punished deliberate murderers, those who attempt to murder the Kaiser or their own sovereign, those who use dynamite with intent to kill, and slavers.

Penal confinement (Zuchthaus) is either for life or from one to fifteen years; it always includes permanent disability to serve in the [ 190 ] 


\section{JUDICIAL SYSTEM OF THE EMPIRE}

army or hold an official position. Imprisonment (Gefängnis) lasts from one day to ten years. The prisoner cannot be forced to work outside of the prison. Fortress incarceration (Festung) presupposes that the criminal did not have a dishonest intention (cases of dueling, espionage of foreigners, etc.). It lasts for life or from one day to fifteen years. Arrest or confinement (Haft) lasts only from one day to three months. Verweis is an official warning. The minimum fine is one mark, the maximum I5,000 marks. Besides these punishments a convicted person may be deprived of his civil rights, placed under the supervision of the police or, if a foreigner, expelled from German territory.

Besides the Criminal Code there exist many Imperial laws which provide penalties; e.g., the Press Law of 1874 , the Dynamite Law of 1884 , the Law regulating Bankruptcy of 1899, the Espionage Law of I890, the Pure Food Law of I 879, and especially the Trade Law of 1869.

The organization of civil and criminal courts in the German Empire is regulated by the "Gerichtsverfassungsgesetz" of October I, 1879.

There is, strictly speaking, only one federal court, the Reichsgericht or "Imperial Court," which sits at Leipzig, Saxony. This is the supreme court and, in general, is only a court of appeals. All other courts are courts of the several states but organized under the rules of the law mentioned above and administering justice ac- 


\section{GERMAN GOVERNMENT AND POLITICS}

cording to principles laid down by the Imperial codes.

The lowest German court is the Amtsgericht. It is a civil as well as a criminal court. At the head of it is one judge, the Amtsrichter, who decides civil cases without assistance. In criminal cases he is generally assisted by two laymen as jurors (Schöfen) who join with him in the decision. All civil cases involving a sum less than 600 marks have to be brought in first instance in an Amtsgericht. As a criminal court the Amtsgericht acts in minor cases and misdemeanors, as enumerated in the law mentioned above.

The middle and higher courts are all collegial bodies composed of several judges.

The Landgerichte are courts of appeal from the Amtsgericht and courts of first instance in civil cases involving more than 600 marks as well as in all serious criminal cases. In civil cases the decision rests with three judges, the Landrichter. For criminal cases the Landgericht is divided into Strafkammern or Chambers for Criminal Cases and Schwurgerichte or Courts of Juries. The Strafkammern deal with crimes punished with a maximum of five years of penal confinement, with recidivists, thieves and concealers of stolen goods. The Schwurgerichte have all other criminal cases under their jurisdiction except cases of high treason against Kaiser and Empire and cases of espionage, which are de[ 192 ] 
cided by the Reichsgericht without appeal. The Strafkammern are composed of five judges, the Schwurgerichte of three judges and twelve lay jurors. In addition to these three divisions or chambers, special chambers for commercial affairs (Kammern für Handelssachen) may be created at the Landgerichte. These commercial courts consist of one judge of the Landgericht and two lay members as his equal colleagues, who are proposed by the chambers of commerce.

Courts of appeal from the Landgerichte, in civil as well as criminal cases, are the Oberlandesgerichte, of which there are twenty-nine in Germany. These courts, as well as the Reichsgericht, are divided into Senate or departments for civil and criminal cases. Departments of the Oberlandesgerichte are composed of five judges, those of the Reichsgericht of seven.

In states with more than one Oberlandesgericht certain cases, otherwise belonging to the Reichsgericht, may be transferred to one of these Oberlandesgerichte. Thus Bavaria since $\mathrm{I} 879$ has had an Oberstes Landesgericht and Prussia the Kammergericht in Berlin. This latter court is also the highest criminal court for Prussia, and the highest court for non-contentious jurisdiction. ${ }^{1}$

The German system of courts is centralized in the Reichsgericht, which was created in $\mathbf{1 8 6 9}$. It

1 A special department of the Kammergericht is the Geheime Justizrat, a civil court for members of the royal house. 


\section{GERMAN GOVERNMENT AND POLITICS}

preserves the unity of judicial decisions for the whole Empire. If one of its senates wishes to alter the decision of the other, it has to do so in joint meeting with the rest of the civil and criminal senates respectively. If a senate for criminal cases wishes to deviate from the opinion of a civil senate, or of all of them, or if a senate for civil cases wishes to deviate from the opinion of a criminal senate, or of all of them, it may do so only by the decision of all the different senates.

The Reichsgericht is a court of third instance in civil cases involving a minimum of 4,000 marks, and a criminal court of appeals from the Strafkammern and Schwurgerichte in cases where the legality of a decision in regard to the subjectmatter is disputed.

For disputes as to questions of law in regard to railways, the Oberlandesgericht has the final decision. In cases of conflict as before which set of courts, ordinary or administrative, a case has to be brought, special courts of the several states have the decision.

Besides this system of ordinary courts, there are special, ordinary Imperial courts, the criminal courts of the navy, and consular courts.

Non-contentious Jurisdlctlon
Non-contentious jurisdiction is the administrative assistance of courts or judicial officers in the creation of private rights.

Together with the German Civil Code there was published an imperial law regulating non[ 194] 
contentious jurisdiction, the "Reichsgesetz betreffend Angelegenheiten der freiwilligen Gerichtsbarkeit." ?

The main subjects of non-contentious jurisdiction are:

I. Registration of land titles. Transfers or change of ownership of land go legally into effect by an agreement between the parties and the registration of this agreement. The state is responsible for any mistake made by the registration officials in the performance of their duty. The officers are in turn financially responsible to the state.

2. Cases of guardianship. The guardians appointed by the courts are under their constant supervision. These courts ratify adoptions, give minors in certain cases the rights of persons of full age and settle domestic disagreements of unimportant character.

3. Registration of marriage contracts, of commercial partnerships, of share companies, etc. ${ }^{2}$

4. Probate matters.

1 Other sources of non-contentious jurisdiction are the Land Registration Act of 1900 ; some paragraphs of the German Civil Code on the making of wills, certificates of inheritance, etc.; some provisions in the Commercial Code, in the Trade-mark Statutes and many statutes of the several states, regulating matters of more local character, as the Prussian Statute of September 21, 1899, regarding noncontentious jurisdiction.

2 Patents and trade-marks are registered by the Patent Office. 


\section{GERMAN GOVERNMENT AND POLITICS}

5. Judicial authentication of written statements, Urkunden or documents. In many of the German states this function is exclusively exercised by notaries instead of by the courts.

When public interests are involved as in cases of guardianship, the courts act ex-officio or of their own motion; in other cases, as marriage agreements, registration of land, etc., they act only upon application.

Non-contentious jurisdiction as far as administered by courts is usually performed by the district courts, the same number of judges sitting as in civil matters. Final appeal from these in cases of violation of law only, not for errors in fact, may be taken to the highest court of appeal in the different states. The Reichsgericht has nothing to do with cases of non-contentious jurisdiction.

Judicial

The leading officers of the German courts are Officers professional judges. Their training is uniform throughout the Empire. After graduation from a secondary school, for at least three years they must study jurisprudence and economics. After they have passed rigid examinations they are admitted to the judicial career as Referendare or assistants. Then they are prepared in the different courts and after three years of service may be admitted to a second examination. After the passage of this examination they receive the title Assessor and are appointed judges if a vacancy occurs. Professors of jurisprudence at [ I96] 
the universities are eligible without examination. At the head of the collegial courts is a Präsident, at the head of the chambers, Directoren, at the head of the senates, Senatspräsidenten. Members of the Reichsgericht must have passed the thirtyfifth year. They are appointed directly by the Kaiser while all the other judges are appointed by the sovereigns of the several states.

Judges cannot be removed or transferred without a legal process and for legal reasons. Politics play no part in the judicial system of Germany. The German people are justly proud of the independence and high sense of justice of their judges. ${ }^{1}$

The jurors of the Amtsgerichte and the lay members of the Kammern für Handelssachen are lay judges without remuneration. They decide only the guilt or innocence of the accused while the judges determine the punishment. Jurors in the Landesgerichte are selected from a list of persons who are thirty years old and have never been convicted by a court.

Each court has a public prosecutor. The prosecutor of the Amtsgericht is the Amtsanwalt, a civil service officer of the middle class. The prosecutors of the higher courts are called Staatsanwälte, or Oberstaatsanwälte at the Landes-

${ }^{1}$ In the year I9I2, e.g., a judge in Kadinen, East Prussia, decided a case against the Kaiser to the great satisfaction of the German people and was praised by the Kaiser after he learned that he had been misled. 


\section{GERMAN GOVERNMENT AND POLITICS}

and Oberlandesgerichte, and Reichsanwälte at the Reischgericht. They have the same training as the judges. They are, however, not as independent as the judges since they have to obey the orders of their superiors. The prosecutors are assisted by the police who must obey their commands.

Attorneys, or Rechtsanwälte, have the same training as the judges. Attorneys who have been admitted to one court are admitted to any court in Germany except for civil cases where they are assigned to certain courts. The attorneys of the Reichsgericht are admitted by the presiding board of this court, and can practice only before the Reichsgericht. Notaries must have the same training as judges. They are appointed by the state and are usually at the same time attorneys.

The clerical service of the courts is performed by secretaries, Gerichtssekretäre, who are officers of the middle class and trained in the principles of law. They are also charged with the records. Other court officers are the bailiff or Gerichtsvollzieher and the beadle or Gerichtsdiener, who have in general the same duties as similar officers in England and the United States.

The governmental powers by which the admin-

The principle of administrative law and a dministrative courts istration of a modern constitutional state is carried on are not arbitrary but are fixed by law and the individual can appeal to the government, if his rights, as guaranteed by law, are violated by governmental agents or officials. All these legal [ 198 ] 


\section{JUDICIAL SYSTEM OF THE EMPIRE}

rules in Germany, as in most continental European countries, are laid down in a special field of law, the so-called "administrative law."

Administrative law is therefore that branch of public law which fixes the details of organization of the government, determines the competence of the administrative authorities and gives the individual redress in case his rights are violated.

Anglo-Saxon jurists, with few exceptions, have denied the existence of a distinct and separate branch of "administrative law." They have above all objected to the advisability of having this branch of law administered by special courts. England and the United States know only one law and one set of courts, the ordinary courts, before which all legal controversies, including those involving public officers, are brought. Germany distinguishes between ordinary law, civil and criminal, administered by ordinary courts, and administrative law, as defined above, administered in the so-called administrative courts. Another characteristic feature of administrative law is that under it the state is held responsible for the acts of its agents rather than the individual officers themselves.

There are many advantages connected with the continental European system. In the first place, it makes for greater efficiency. Undoubtedly the supervision of purely judicial courts and their interference in administra tive affairs is detrimental 


\section{GERMAN GOVERNMENT AND POLITICS}

to prompt and efficient administration. Furthermore, the decision of cases in administrative matters requires a thorough knowledge of the technique of administration. This knowledge is not usually possessed by judges of ordinary courts. Not admitting any distinction between administrative and ordinary law they apply the same methods to the enforcement of laws of a different character. Not recognizing the special nature of Government as the representative of all citizens, they often decide against public welfare in favor of private interests. The execution of administrative law requires men with special training and a public mind.

Finally, the individual can, if he has suffered injury, get better satisfaction under the continental system if the court decides in his favor. For example, a policeman who in the supposed performance of his duty injures an individual, would in the United States or England be held personally responsible. It is very doubtful, however, if the plaintiff could collect any substantial damages as a result of a verdict in his favor. Under the continental system the government would satisfy the plaintiff.

There is, on the other hand, a justifiable objection to the continental system. If the administrative courts were not composed of men with a high sense of justice, they might too strongly uphold the government which they represent, and the individual, for political reasons, might

[200] 


\section{JUDICIAL SYSTEM OF THE EMPIRE}

never get satisfaction. This was actually the situation in France under the régime of Napoleon III. The administrative courts were instruments in the hands of the imperial government. Dicey, the eminent English jurist, took these French courts as types of administrative courts when he condemned the whole system.

As far as Germany and her states are concerned, we may safely say that the system of special administrative law and courts works to the full satisfaction of both government and individual citizens. ${ }^{1}$

In Germany administration is generally left to the several states, therefore we find comparatively

1 Dicey confesses (in his "Introduction to the Study of the Law of the Constitution," 7th edition, 1908, Chapter on "Droit Administratif ") that he received his knowledge of administrative law from $A$. de Toqueville, who, by his own admission "knew little or nothing of the actual working of "droit administratif' in his own day." And those days.were furthermore the days of the régime of Napoleon III. Dicey's misconception of the administrative law of to-day is expressed in sentences like the following: "The 'droit administratif' rests upon political principles. Official courts are supported because they have an official bias. It is a body of law intended to preserve the privileges of the state. The separation of powers, as the doctrine is interpreted in France, assuredly means the protection of official persons from the liability of ordinary citizens," etc. Under Dicey's influence President A. Lawrence Lowell of Harvard criticized the administrative courts in his "Governments and Parties in Continental Europe," but after a more careful study he changed his opinion in his more recent publication, "The Government of England" (Vol. II, pp. 489-504). The first and most prominent defender of adminis- 


\section{GERMAN GOVERNMENT AND POLITICS}

Administrative courts of the German Empire

little administrative law and few administrative courts of the German Empire. The several states have the more complete system.

The basis for the administrative law of the German Empire is the constitution, which lays down the fundamental principles of the administration. It does not contain a bill of rights like that of Prussia and other states. These civil rights are either accepted as self-evident or fixed by special laws, as the law in regard to citizenship, the law concerning the right of forming clubs and of public meetings ("Vereins- und Versammlungsrecht" of April 19, I908), the law giving freedom of domicile and acquisition of real property, business occupation, and emigration, and the law abolishing passports.

There are several special administrative courts of the Empire. The Reichsamt für das Heimatwesen is a permanent collegial body consisting

trative law and administrative courts, among English speaking writers, was Prof. F. J. Goodnow, who was influenced by German university studies (see his "Comparative Administrative Law, Vol. I, pp. 217-239). An interesting criticism of Dicey's point of view is E. M. Parker's article "State and Official Liability," in the "Harvard Law Review" of March, 1906, pp. 335 ff.

It might be noticed that the Anglo-Saxon practice has in recent years recognized the advantages of administrative courts by investing administrative bodies with judicial functions, as, in England, the Boards of Trade, Education, Local Government, etc.; in the United States, the Pension Office, and the Interstate Commerce Commission.

[202] 
of a president and at least four members. It is a court of last instance in disputes between public "Corporations for the Relief of the Poor" of different states or as far as the legislation of the state has transferred the decision of cases between corporations of its territory to the Reichsamt. ${ }^{1}$

The Erweiterte Reichseisenbahnamt is an administrative court for cases arising from regulations made by the Reichseisenbahnamt. It is the latter body enlarged by several judicial members. At least two judicial officers and three original members must be present to give a decision.

The Reichsrayonkommission is a permanent military commission, appointed by the Kaiser, sitting as a court of appeal for complaints against decisions of commanders of fortresses, who are frequently brought into disputes in guarding the surroundings of fortresses.

The Oberseeamt is a collegial body, consisting of six members, of whom three must be navigation experts and one, the presiding officer, a qualified judge. They decide complaints against the Seeämter or Navigation Offices, which investigate the causes of naval accidents and which may disqualify naval officers.

The Reichsversicherungsamt is a court for cases

1 Prussia, Hesse, Saxe-Weimar-Eisenach and some smaller states have done this. Bavaria has as a special privilege her own legislation in regard to the relief of poor people, therefore the Reichsamt is not competent for Bavaria. However, Bavaria decided to give up this privilege in I9I4. 


\section{GERMAN GOVERNMENT AND POLITICS}

coming up from the association-offices (Genossenschaftsämter) and the courts of arbitration for the state insurance of invalids and aged people.

The Aufsichtsamt für Privatversicherungen decides disputes of private insurance companies which are under its supervision, e.g., those companies which do business in several German states as well as those of a few smaller states.

The Patentamt (Patent Office) is composed of a president and legal and technical members. They are appointed either for a period of five years or for life.

\section{SELECTED BIBLIOGRAPHY}

Borchard, E. M. "Guide to the Law of Germany."

Howard, B. E. "The German Empire," Chapter IX (The Judicial Organization of the Empire).

Burgess, J. W. "Political Science and Comparative Constitutional Law," Vol. II, Division IV, Chapter III (The Organization and Powers of the Judiciary in the German Imperial Constitution).

Garner, J. W. "The German Judiciary." 


\section{CHAPTER XVII}

THE PARLIAM E N TARY H ISTOR Y OF G E R A N Y

W HILE in former times parties in general were based on philosophical and political principles, and drew their followers from all classes, at present they are mostly representative of classes and economic and social interests. Few are those who view the problems of government from a broad, unselfish, national standpoint.

The first element to present itself frankly as the representative of a single class was the SocialDemocratic party, the party of the workingmen. It still essentially represents their interests although its influence has begun to be felt among farm workers and small shopkeepers.

The Conservatives have always had their stronghold in the country. It was only natural therefore that they should make themselves the special protectors of the agricultural interests, which rôle they definitely adopted with the foundation of the Agrarian Union (Bund der Landwirte), in 1893 . This Union at first formed a party by itself. Later on, however, its members

1 The party programs referred to in the following chapter may be found in K. Mahler, "Die Programme der politischen Parteien in Deutschland." 


\section{GERMAN GOVERNMENT AND POLITICS}

joined the different conservative groups, the right wing of the National-Liberals, the Clericals and the Poles. Their influence has given to these conservative parties a decidedly agrarian character.

The Liberals find their support especially in the cities, the seats of commerce and industry, whose logical representatives they have become. In I909 appeared the Hansabund, the counterpart in industry and commerce of the Agrarian Union. It has its followers among all the liberal groups from the radical Left to the National-Liberals.

The Center less than any of the other great parties is the representative of economic interests. In the main its members are Agrarians, since the majority belong to the farming classes. However, a great many are workingmen in Catholic cities, so that the party must needs emphasize social reform. The fundamental principle of this party is not economic but religious.

The following statements give roughly the representation of economic and social classes in the different parties. ${ }^{1}$

Conservatives - Large landed property and nobility.

Free Conservatives - Industrialized landed property.

Economic Union - Smaller and urban landed property, crafts, shopkeepers, officers of middle rank.

1 Taken with modifications from Chr. Grotewald, "Die Parteien des Deutschen Reichstags."

[ 206] 


\section{PARLIAMENTARY HISTORY OF GERMANY}

National Liberals - Large industrial and commercial interests, science and education.

Liberals - Commerce, science, crafts, smaller farming property, lower and middle class officers, groups of workingmen.

Social-Democrats - Workingmen.

According to the interests they represent, the parties have logically the following tariff policies.

Conservatives - High protective tariff for agricultural products.

Free Conservatives - The same, and also high tariff for industrial products.

Economic Union - The same, and protection of small shops and crafts.

National Liberals - The right wing believes in a high protective tariff especially for industries, the left wing in a moderate protective tariff.

Liberals - Free traders by principle, however many of them no longer accept free trade as a dogma.

Social-Democrats - Absolutely free trade.

Clericals - Protection, especially of agricultural products.

Let us now consider the philosophical, religious, and political principles of the different groups.

The basis of all conservative thinking is authority. Authority is delegated by God. Therefore the Conservatives believe in a monarchy by the grace of God, and are fundamentally opposed atives to popular government, especially the introduction of parliamentary government. Religion as 


\section{GERMAN GOVERNMENT AND POLITICS}

the source of authority in a Christian state has to be protected, and must permeate the whole life of the nation. The church must have a necessary amount of freedom and the state has no right to interfere with its inner organization. As a matter of fact the Conservative Party means particularly the orthodox church, when it speaks of the church, while the liberal part of the church leans towards the liberal parties, especially the National-Liberals. The public school should, according to conservative ideas, be under the supervision of the church and the religious spirit should be the basis of all education. Under the influence of the former courtminister, Stöcker, the conservative parties turned to anti-Semitism. And this was quite natural since the Jews were found among their natural enemies, the captains of industry and commerce. The anti-Semitic feeling has been strong in Germany from time to time, and has induced a good many people to join the conservative parties.

The Conservatives of the right wing have particularistic tendencies, especially Prussian. Thus the Tivoli program of 1892 says: "We wish that within the unity (of the Empire) the natural independence and character of the individual states and races be preserved." The Conservatives have always supported the military, naval and colonial policy of the government. The social policy advocated by the Conservatives is an extensive one based on patriarchal principles. Consistently [208] 


\section{PARLIAMENTARY HISTORY OF GERMANY}

with their fundamental idea they believe in the so-called state socialism or neo-mercantilism of a real Christian state, the fruits of which were the great compulsory insurance laws of the eighties. The conservative parties emphasize social legislation for the agricultural population and the middle class. They do not mean that these reforms should be regarded as a right of the people, but as a voluntary, though just and necessary, gift of authority. The Tivoli program sums up the aims of the Conservative party in these words: "High esteem for Christianity, monarchy and fatherland, protection and promotion of all honest labor, conservation of natural authority - these are the supreme principles which the German Conservative party has written on its flag."

The Free Conservatives are more liberal, and especially more national in their views. Their program declares "The motto of the party is and remains: The fatherland above the party, the common interest above special interests." They are as they say a constitutional middle party, which has always endeavored to unite all patriotic men against socialistic, radical and reactionary movements.

The Economic Union emphasizes its agrarian character and advocates social legislation for the benefit of the middle class.

Other small parties, which have existed from The Free Conservatives

Small conservative groups time to time, have laid special emphasis upon a certain conservative policy, as, e.g., social legis- 


\section{GERMAN GOVERNMENT AND POLITICS}

lation upon Christian principles (The ChristianSocialists), protection of agriculture (Agrarian Union), anti-Semitic policy (Antisemiten, DeutschSociale, German Reform Party).

The Clericals, in spite of their denial, form a

The party based thoroughly upon the Catholic religion. Clericals This is their first and supreme principle. Whenever national and Roman Catholic interests conflict they are found on the side of the church. Again and again they have abused their power in the Reichstag to benefit the church as against the state. Politically, however, they are far more progressive than the Ultra Conservatives, and if that portion of their number who place nationalism above clericalism should ever gain the upper hand, the Center - which then would be the better name - would find a great number of followers among the non-Catholic mass of Germans. For with a sound conservatism they combine many democratic policies, and are not as far removed from the mind and heart of the people as the Conservatives. They have promoted the social reform policy of the Government, have fought against monopolies and the dangers of the concentration of wealth. In their social reforms for the workingmen they go farther than the Conservatives.

The Clerical party has always jealously guarded the rights of the Reichstag, and they have watched the budget of the government with especial care. They like to pose as the party of economy. The [210] 
result is that often they vote against absolutely necessary expenditures for the army, navy, or colonies. Their enthusiasm for imperialism is not very great. Significant is their Wahlprogramm (platform) of 1903 , in which they say: "The expenditures for the colonies, in the extension of Christian faith and civilization, have their limitation in a correct understanding of our financial capability." This clause was given as the motive for the action of the party in $1907,1^{1}$ which better than any program has shown the fundamentally non-national character of this opportunist party. It must be said that the Center has been more cleverly led than any other German party.

The liberal parties are the parties of individualism. The welfare of the individual, personal liberty, is their highest principle. This principle The Liberal Parties has within it the danger of a split into a mass of small groups, since individualism repels partisanship. And as a matter of fact no party has been divided into so many little factions as the Liberal Party. It is a party resting on theories of the natural rights of men. It is made up of a highly intellectual class of political thinkers, but poor practical politicians. Till lately they followed in social policy the old laissez-faire doctrine, an attitude quite consistent with their fundamental ideas and entirely natural in a party representing big business. It must, however, be admitted that they now count among their members several

1 Cf. p. 230. 


\section{GERMAN GOVERNMENT AND POLITICS}

great social reformers (e.g., the former Protestant minister Naumann), and are working with the rest of the Reichstag for the introduction of further reforms. They value self-help very highly, and demand absolute legal equality between employers and employees, as well as the absolute right of coalition of all working people, including farm laborers and servants. Thus their methods of social reform differ from those of the patriarchal Conservatives. Since r9I0 the Liberals of the Left have once more united, so that now we have two big liberal groups: the National Liberals and the Radical Liberals.

The National Liberals emphasize the principle

The

National Liberals of the fatherland above the party, the general welfare above all special interests. They are the most ardent believers in imperialism, and are perhaps nearer than any other party to the spirit of modern Germany as represented by the German Emperor. Historically, they are the party of nationalism and they still favor centralization. Their political faith is truly liberal, but opposed to all radical tendencies. They recognize the importance of the church, but with the understanding that the state is always the superior. In their tariff policy they give their members absolute freedom of opinion. Most of them, however, are, as said before, protectionists.

The Radical Liberals, or simply Liberals, The demand absolute equality, social and political, Llberals direct elections and universal suffrage in state [212] 
and local government, revision of the electoral constituencies, introduction of parliamentary government, development of local self-government, independence of schools from the church, more direct and fewer indirect taxes.

The principles of the Social-Democratic party are internationally well known. In brief, their economic aim is the socializing of all means of production; their political aim is a direct and

The

SocialDemocrats absolute democracy. Among the political demands of this party are: woman's suffrage, proportional representation, initiative, referendum, political responsibility of officials who are to be elected by the people, absolute freedom of speech, a free church, independence of schools from the state, free schools and universities, free legal and medical help, abolition of all indirect taxes, progressive income and inheritance taxes. It is a well-known fact that the German Social-Democrats, as is indeed the case with the Socialists of all countries, are internally split between the Orthodox Radicals, who refuse to participate in reform legislation and the opportunist element, Revisionisten, who are ready to support any legislation tending towards socialism, and who no longer accept all the Marxian doctrines as do the Orthodox Socialists. So far the radical wing is still in the majority and directs the policy of the whole party although the revisionist element is constantly growing stronger. It is undoubtedly true that a large part of the Socialist 


\section{GERMAN GOVERNMENT AND POLITICS}

voting strength comes from persons not fully in sympathy with the economic ideas of Karl Marx, but who are influenced by a desire to protest against existing conditions of government in Germany. Often it has been questioned whether the Social-Democrats in case of war would take arms for the Empire. Of course socialistic theory is opposed to imperialism and militarism. Those who count, however, on the unpatriotic spirit of socialistic Germans in case of a defensive war undoubtedly make a mistake. ${ }^{1}$ Thus one of the leaders of the Social-Democratic party, von Vollmar, declared at the International Socialist Congress of 1907, accompanied by the cheers of many in the audience, that love of humanity would never prevent his party from being good Germans, and that the idea of putting an end to war by a general strike was foolish.

Besides these four big groups of parties - the Conservatives, Clericals, Liberals, and SocialDemocrats - there exists a number of smaller parties, which from a racial viewpoint all protest against their position in the Empire. Of these the Poles, Alsatians, and Guelphs vote with the Center in matters of general policy, while the one representative of the Danes in the Reichstag is a guest of the Liberals.

The party history of the German Reichstag

1 This statement was written before the outbreak of the European war.

[214] 
begins in the Constitutional Assembly of Prussia, 1848; and in its successor, the Prussian Chamber of Deputies. The first Prussian Chamber of Deputies, which was elected in 1850, contained a majority of Conservatives, with only a few scattering Liberals, because the Liberals did not participate in the election, as a protest against the form of franchise forced upon them. Indeed we can hardly speak of real parties during this time. The people elected a man more for his personality than on account of his political affiliations. With the ascendency of William to the throne of Prussia in $185^{8}$, the Liberals formed a great party and became active in the Chamber, at first supporting the new government from which they expected a liberal course. But they quickly turned to opposition, when the King with Bismarck and Roon proposed the great reorganization of the army. Only then did real party organization for the purpose of carrying elections come into existence. The Liberals were opposed to the military reform, the Conservatives favored it. At the same time, the Liberals advocated a German-National policy, while the Conservatives were Prusso-particularistic. In 1863 the Liberals had 247 seats, the Conservatives 105. But Bismarck despised this majority and went on with military reforms without its consent. History justified his action. While battles were being fought in Bohemia in 1866 a new Landtag was elected, in which the people condemned

ReorganIzation of the army

\section{History \\ of parties}

The parties of the

Prusslan Chamber of Deputies from 18481866 he 


\section{GERMAN GOVERNMENT AND POLITICS}

the policy of the Liberals. ${ }^{1}$ The dominance of the Liberals in the Chamber passed once and forever.

The Liberal majority was succeeded by a major1866- ity consisting of the National-Liberals and the

The

National Liberals and the

Free-

Conservatives as government parties Free Conservatives. The National-Liberals came into existence partly through the desertion of the more moderate Liberals, who now became reconciled with Bismarck's policy, and partly by the adherence of the members of the National Club, the Nationalverein. This Nationalverein was created in 1859 under the leadership of Bennigsen, and comprised all the elements in Germany who believed in a German Empire under Prussian leadership on the basis of moderate liberal institutions. Almost all the prominent men of learning in Germany joined the National-Liberals, among them the great historian Treitschke, and Gneist, the spirit of reform in Prussian local government. It became the great popular party. In the Constitutional Convention for the North German Federation the National-Liberals had already eighty seats. They must be given special credit for the passage of the Constitution, which was adopted by 230 against 50 votes, the minority being composed of Liberals, Clericals, Poles, Guelphs and Danes.

Contemporaneously with the National-Liberal party, the Free-Conservative party was created.

${ }_{1}$ Their official name was Fortschrittspartei or Progressive Party.

[216] 
This new party separated from the old Conservatives, which henceforth called themselves GermanConservatives. The reason for the separation was a more progressive point of view, a more pronounced nationalism and an almost unlimited faith in Bismarck. They have been baptized the "Bismarck party sans phrase." Since 1867 they have called themselves the Imperial party or Reichspartei.

During the period of the predominance of these two parties the structure of the German Empire was erected and cemented. Their difficult task all fair-minded critics must confess was accomplished with brilliant success.

Soon after the establishment of the new Empire, the government became involved in a deplorable and bitter struggle with the Catholic Church. Fundamentally it was the old medieval German fight between church and state, the fight between the Roman principle of binding authority and the Protestant doctrine of free individuality. After the Italians had deprived the Pope of his temporal power the archbishop of Posen in behalf of all Catholics asked Bismarck at Versailles in 1870 to restore the old temporal power of the Pope. Bismarck coldly refused to do anything in that direction, whereupon a Clerical party was at once organized, with the purpose of restoring the temporal power and the independence, or even superiority, of the Catholic Church. With the help of the clergy, the Clericals conquered $5^{8}$ 
seats in the first Imperial Reichstag, and 47 in the corresponding Prussian Chamber of Deputies.

The conflict between this party and the government broke out as a result of the dogma of Papal infallibility in speaking ex cathedra. The German bishops had opposed the new dogma in the Vatican Council. But after it had been accepted they submitted to it, except a few under the leadership of Döllinger, the distinguished professor of theology in Munich. They were consequently excommunicated by the Catholic Church and formed a church of free thinking Catholics, the so-called "Old-Catholics." The government came to the help of the Old-Catholics. The Reichstag, at the proposition of the government, forbade the religious orders to engage in teaching. In 1872 , the Order of Jesus and afterwards other orders were expelled from German territory. In May 1873, 1874, and 1875, the Prussian Landtag ${ }^{1}$ passed a number of laws directed against the power of the Catholic church, providing for the supervision of education by the state, the appointment of the clergy by the state, compulsory civil marriage and suppression of religious orders.

The clergy refused to obey the laws, which the Pope declared void. The government enforced them by fines, imprisonment, non-payment of salary and expulsion from the country. Hundreds of congregations in Prussia were without priests and church services; baptisms and marriages

1 Falk was Minister of Education. 
stopped. All Germany was excited, the priests posed as martyrs, the mass of Catholic people looked upon them as half-saints and the ends of the government were not accomplished. In 1877 the Clericals returned 92 members to the Reichstag and became the strongest party in that body.

The Kulturkampf, as this struggle has been called, only enhanced the power of the Clericals. Therefore Bismarck, who needed the help of the Clericals for other reasons, made peace with them. This was greatly facilitated by the death of Pope Pius IX and the election of Leo XIII, a man of more liberal mind and of great diplomatic skill. In the years following 1878 one law after another of the Kulturkampf period was abandoned so that now only civil registration of births and deaths, civil marriages, inspection of schools and the provisions excluding the Jesuits as an order are left. Individual Jesuits are now admitted.

The year I874 saw the climax of the strength of the National-Liberals. It seemed impossible in the early seventies that so strong a power could be broken in so short a time. And yet it took only seven years, from 1874 to $188 \mathrm{I}$, to diminish their

Fall of the NationalLlberal party strength from 152 to 45 seats, a point at which they have remained ever since, except in 1887 when they won 99 seats. Many reasons account for this sudden decline. In the first place must be put Bismarck's change of attitude toward the party. He was turning more and more to conservative ideas. Furthermore he was, as always, afraid 


\section{GERMAN GOVERNMENT AND POLITICS}

of the power which a very strong and united party might gain in the Reichstag, a power which in the future under a weak Kaiser and Chancellor might be used to introduce the English form of government which he abhorred.

The two main causes of Bismarck's alienation, however, were his differences of opinion with the National-Liberals in regard to imperial finance and the treatment of the Social-Democrats. After the war indemnity had been consumed to support the new government, it was necessary to find other resources. This the National-Liberals saw as well as Bismarck, but they feared a loss of power in the Reichstag, if they voted permanent imperial taxes without some safeguard. For according to the German constitutional system, taxes once granted cannot be repealed except by the process of constitutional amendment, in which case Prussia has a veto. The Liberals therefore demanded the creation of a Secretaryship of Finance, responsible to the Reichstag, in return for the concession of the necessary taxes. Bismarck, consistent in his fear of parliamentary government, declined to work with the Liberals under such conditions. Discouraged and disgusted because of the lack of harmony with the leading party in the Reichstag and because of his defeat in the Bundesrat in 1875 on the question of bringing all the railroads of Germany under government ownership, he took a long leave of absence in April, 1877.

[220] 


\section{PARLIAMENTARY HISTORY OF GERMANY}

During his absence from official duties he made up his mind either to bind the National-Liberals closely to him or find his support in the Clericals and Conservatives, who were beginning to weaken in their opposition to him. First he offered a portfolio to Bennigsen, the leader of the National-Liberals. He was willing to accept only on the condition that another liberal leader be given a portfolio, in order to insure a liberal policy on the part of the government. Bismarck's plan, however, was just the opposite, namely to make the National-Liberals Conservatives. Moreover, Bennigsen and his party objected to the introduction of a government tobacco monopoly planned by the Chancellor. Bismarck then took decisive action. The three liberal Ministers in the Prussian Cabinet were replaced by more conservative men, and henceforth no bills of a liberal character were introduced by the government. In the elections of 1878 the government did not support the National-Liberals with its prestige, and while no announcement had been made, everybody knew that a breach had taken place. The result was a loss of twenty-nine seats for the NationalLiberals. The time of their hegemony had passed. The two conservative groups returned more members than the National-Liberals, and the Clericals almost as many.

Let us return for the moment to the SocialDemocrats and the anti-socialistic policy of 


\section{GERMAN GOVERNMENT AND POLITICS}

The rise Bismarck. In the year I 848 the "Communist of the SocialDemocratic Party Manifesto" of Marx and Engels had been published. It concluded with the famous words: "The ruling classes may tremble in case of a communistic revolution! The proletarians have nothing to lose but their chains. They have a world to win. Proletarians of all countries unite!" But the union of communists founded on the principles of the Manifesto ceased to exist, and in 1854 all clubs of workingmen in Germany were dissolved. May 23, 1863, can be given as the birthday of the modern Social-Democratic party in Germany. It was the date of the foundation of the German Workingmens' Union by the brilliant, active Ferdinand Lassalle. After his death in 1864, a period of struggle began within this union. For the Constitutional Convention of 1866 a program was put forth, the Erfurt program, but only 40,000 votes were given for all the socialist candidates and not one was elected.

The first Reichstag of the German Empire saw only two socialist members. ${ }^{1}$ In 1875 the internal struggle between the more nationalistic and opportunist followers of Lassalle and the international, revolutionary party was settled at the Congress of Gotha. Meanwhile in the elections of 1874 , the number of votes for socialist candidates had increased to 351,670 , and nineteen members had been elected to the

1 Bebel and Schraps.

[222] 
Reichstag. Germany became excited and extremely nervous.

At that date fears were entertained of Socialists which have since been allayed. They had not settled down to a definite policy. The belief in revolution and the use of force was prevalent. The general public confused them with their greatest opponents, the anarchists of action, and regarded them as half-devils. Above all, Bismarck, the builder and pilot of the ship of state was nervous in the fear that this destructive element would destroy his great work. Instead of following the advice of the so-called "Socialists of the Chair," who, much after the fashion of Progressives in the United States, advocated social reforms as the only way to stop the socialistic flood, he applied to them the same methods which he had used unsuccessfully against the Clericals. In 1875 he proposed in the Reichstag a bill to punish spoken or printed attacks on the state. The clauses affecting Socialists gave so much discretionary power to the administration that the National-Liberals and even some of the Conservatives voted against them. When in 1878 after an attempt at violence on the old Kaiser, Bismarck tried to have an "exception" law, or piece of special legislation, passed to suppress the Social-Democrats, he was again defeated by the National-Liberals in the Reichstag. A second attempt on the life of the Kaiser in the same year, made this time by a 


\section{GERMAN GOVERNMENT AND POLITICS}

man who confessed to be a Socialist, gave the Chancellor the opportunity to dissolve the Reichstag with the result shown above.

Although there was still no open breach with

$1878-$

1887.

No majority,

the

Clericals holding

the

balance of power

Introduction of the protectIve tariff the old government party, and the exception law had been passed in a modified form with its assistance, Bismarck had now made his peace with the Clericals, and depended mainly on them and the Conservatives. In February, 1879, he introduced in to the Reichstag a bill for a protective tariff. Like most European scientists and statesmen, Bismarck had been a believer in free trade. A change of opinion, however, had been taking place among the German economists, especially on account of the weak condition of the young industry of the Empire. Bismarck, like many economists, was influenced by the experience of the United States as a country of rapidly progressing industry, which he ascribed to its system of high protection. ${ }^{1}$ At the same time the customs duties offered an enormous source of income which Bismarck needed badly, all his plans to find sufficient financial support for the imperial government having failed. The parties which up to that time had all believed in free trade divided again upon this issue. The Conservatives became

1 "For the abstract teachings of science in this connection I care not a straw. I base my opinion on experience, the experience of our own time. I see that protectionist countries are prospering, that free trade countries are retrograding." Bismarck in a speech in the Reichstag of May 2, 1879 .

[224] 
advocates of protection; the Liberals and the Socialists continued to oppose it. The NationalLiberals and the Clericals split among themselves. Bismarck made further concessions to the Clericals for their support of his policy, since Bennigsen could not promise that all National-Liberals would follow him. When the final vote was taken, a small part of the National-Liberals voted for the protective tariff and separated from the party as the "Liberal Group." 1 In the year I880 the left wing split from the NationalLiberals as a consequence of differences on commercial policy, and formed a party of liberal free traders, the Liberale Vereinigung (LibSplit of the Llberal Parties and their eral Union) or Secessionists. These secessionists united in 1884 with the Old-Liberals, but separated again in 1893 . The older more radical party took the name Free Thinking People's Party (Freisinnige Volkspartei), while the more moderate faction gave itself the name of the Free Thinking Union (Freisinnige Vereinigung). These two parties together with the South-German People's Party (Süd-Deutsche Volkspartei), a particularistic democratic party in South Germany, united in 1910 as the Progressive People's Party (Fortschrittliche Volkspartei) so that now there exists essentially one Liberal Party of the Left.

We have briefly shown in the foregoing the complete breaking of the formerly commanding

1 There were fourteen members, but only one was returned at the next elections, and so this faction ceased to exist. 


\section{GERMAN GOVERNMENT AND POLITICS}

power of the National-Liberals. The rest of the party under Bennigsen continued to support Bismarck, voting in $\mathbf{1} 880$ for the prolongation of the anti-socialistic law and for the "Septennate," i.e., the bill fixing the size of the army for seven years. The Clericals for whom Bismarck partly had sacrificed the National-Liberals and to whom he had made concession after concession, did not prove to be faithful allies, and took in general a hostile attitude under the leadership of Windthorst. It was often extremely difficult for the government to obtain a majority. There was no compact following behind Bismarck and his party policy had to be made for each measure. There was constant lack of harmony between the government and the Reichstag. A conflict more than ordinarily serious led to the dissolution of the Reichstag in 1887 . Boulanger's cry of revenge for Alsace-Lorraine and French preparations for war, made a prolongation of the Septennate and an increase of the army desirable. But the Liberals of the Left, the Center and the Social-Democrats ridiculed the imminent danger of a war, and in spite of all the effort of Bismarck to unite the German representative body against the menace from the west, the majority of the Reichstag voted against the project of the government.

The elections to the new Reichstag took place under the greatest excitement. The government exerted all its prestige for the election of the Con-

[ 226] 
servative and the old National-Liberal candidates. 1887Never before had such a percentage of voters participated in an election. The result was a Reichstag with a solid government majority for the Septennate. The new Reichstag was the willing instrument of Bismarck. With its help he increased the legislative period from five to three years.

Bismarck greatly modified his policy towards the Social-Democrats during the eighties. By the adoption of "State Socialism," the passage of laws for compulsory insurance of workingmen, he sought to remove the causes of their opposition as far as they seemed to him justified. On the other hand, he continued to use repressive measures, destroying their press, putting their leaders 1890.

The

Cartel 1

Reichstag. Coalition of Conservatives.

Free

Conservatives and National Liberals.

The Septennate

Ant1-

Socialist legislain prison or exiling them for seditious speeches, suppressing their meetings, etc. The result was the same as in the case of the Kulturkampf. As martyrs they gained strength from the admiration of the multitude, became more fanatical and more solidly organized. With the exception of the elections of 1887 the party grew steadily. The Chancellor, instead of changing his unsuccessful policy, introduced new anti-socialist laws after the termination of the period of the "Exception laws" in 1889. The National-Liberals who in principle were opposed to these laws assisted the Clericals and Liberals of the Left to amend them so as to make them less severe, much against Bismarck's desire. For yet other

1 A cartel is a combination of party groups - a bloc. 


\section{GERMAN GOVERNMENT AND POLITICS}

reasons the Conservatives voted against them at the last reading in January, 1890 , and the whole bill was rejected.

At this juncture the term of the Reichstag expired and new elections took place. These 1890- elections returned to the Reichstag only a min-

1907.

The

ConservativeClerical bloc ority of the cartel parties which had supported Bismarck. This loss of control over the Reichstag was one of the reasons which contributed to the fall of Germany's first Chancellor. ${ }^{1}$

The refusal of the Liberals to vote for a bill increasing the strength of the army, forced Caprivi, the new Chancellor, to seek support first from the Conservatives and Clericals. He therefore made new concessions to the Clericals, restoring to the Catholic Bishops the revenues withheld during the Kulturkampf by a bill passed in the Prussian Landtag. The old enemies of the Clericals, the National-Liberals, who were joined by the Free Conservatives, were ineffectual in their capriv's opposition. Caprivi, however, proved to be just clal as independent of the Conservatives as he was treaties of the Liberals. At the end of r89 he introduced a series of reciprocity treaties favoring industry, a truly liberal economic policy. In spite of the opposition of the Agrarian element in the Conservative party the treaties were passed in the Reichstag by a large majority. AnEduca- other victory of the Liberals, not due, however, tion Bill to their strength in the Prussian Parliament, 
was the failure of the education bill of 1892 , which would have afforded to the clergy of the different denominations the right of giving religious instruction in schools. The Government had first strongly advocated this bill presented by it to the Prussian Landtag. Conservatives representing the orthodox Protestants, and Clericals welcomed it heartily, but the country at large objected very strongly to its passage, so that the government finally withdrew the measure. The Conservatives and Clericals were extremely dissatisfied with the government and showed their attitude on several occasions.

On May 6, 1893, the project of the government to increase the size of the army and decrease the term of service from two and a half to two years Army Bill of was rejected by the Reichstag against the votes of the Conservative parties, the National-Liberals and a few Clericals. The Reichstag was immediately dissolved. The new Reichstag accepted the changed project of the government, the nineteen Poles voting in favor of the bill in return for the conciliatory policy of the Kaiser. However, the government majority was very small and by no means firm in its support of Caprivi. Soon it became necessary for the government to turn again to the Clericals for support. After a very short interval the Blue-Black Bloc, ${ }^{1}$ the union between Conservatives and Clericals,

1 So called because blue is the color of the Conservatives and black that of the Clericals. 


\section{GERMAN GOVERNMENT AND POLITICS}

was again leading in the Reichstag, and remained in this position throughout the chancellorships of Hohenlohe-Schillingsfürst and Bülow until 1907. The elections of 1903 reduced the bloc to a majority of but one. However, in all important national questions Bülow could count on the support of the National-Liberals.

Then came the year 1907. The Clerical party Breach had abused its power and had repeatedly forced
with the Clericals, 1907.

Decrease of the SocialDemocratic party the government in turn for its support to grant it special favors, especially in regard to the Catholic church. It was an unpatriotic policy of bargaining, of Kuhhandel ("cow-trading") as the German political phrase has it. It was a dangerous policy for the government to depend on elements so unreliable which look first ultra montes, ${ }^{1}$ over the Alps, and regard the fatherland as of secondary importance. When therefore the Center refused to vote the necessary money to put down the rebellion of natives in Southwest Africa and thereby, in alliance with the Social-Democrats, defeated the government, the Reichstag was dissolved. The motto of the government was "The fatherland first, the party second! Against Center and Socialists!' Never before had Germany shown such an interest in an election. Artists, professors, philistines, who had never cared to vote, became enthusiastic partisans. All the parties united to defeat the Clericals and the Social-Democrats on the first

1 Therefore they are often called Ultramontanen. [230] 
ballot if possible. Without any reserve they united at the second election (Stichwahl). When the result of the election showed a majority of conservative and liberal groups, joy was unlimited. At midnight a crowd of thousands of citizens marched to the Imperial Palace in Berlin and greeted the Kaiser with enthusiasm equal only to that of the day of the declaration of war against France in 1870. The Kaiser addressed the jubilant crowd with the following words: "Gentlemen, I thank you for your ovation. To-day all of you have put your hands to the work, and have proved the word of the Imperial Chancellor, 'Germany can ride, if she cares to.' I hope this will be true not only to-day but also in the future. If men of all ranks and faiths stand together, we can ride down all those who block our path." 1

The elections however did not break the power of the Clericals, against whom in particular the fight had been made. On the contrary, they gained two seats. The Social-Democrats, however, to everybody's surprise lost about half their seats, although their total number of voters showed a considerable increase. This fact was due to the coöperation of the conservative and

1 Quoted from L. E. Barker, "Modern Germany," Chapter XIV, p. 322. This writer's presentation of the 1907 election is, however, an artificial misconstruction, made by one who sees in everything Germany does a policy hostile to England. 


\section{GERMAN GOVERNMENT AND POLITICS}

liberal groups, to the participation of patriotic men, who had not been in the habit of voting, and to the huge population of the city constituencies, resulting in socialist representatives having a larger body of voters behind them than is the case with other parties.

Bülow now governed with a new bloc, the

1907-

1908.

The

ConservativeLiberal Alliance Conservatives and Liberals. But the alliance, formed in a moment of enthusiastic patriotism, was fundamentally unnatural and did not last very long. In 1908 the government proposed the introduction of new taxes, in order to put the finances of the Empire upon a sound basis. The project of the government was accepted by the Liberals, National-Liberals and Free Conservatives, but the Conservatives refused to accept under any circumstances the extension of the inheritance tax to widows and children. Bülow, who saw his bloc destroyed, resigned, and the old bloc of the Conservatives and Clericals came again into existence.

Financial reform was achieved with the help Since of the Blue-Black Bloc in such a way as to benefit landed capital, while industry and commerce were taxed heavily. The middle and lower class paid the larger part of the new taxes. In addition the cost of living increased as in all countries, and the high tariff on necessities of life was regarded as mainly responsible for this increase. The government, however, refused to modify the tariff. Furthermore the independent

[232] 


\section{PARLIAMENTARY HISTORY OF GERMANY}

element among the Protestants disliked the predominance of the Clericals. The whole country was extremely discontented and many predicted an enormous gain of seats for the Social-Democrats at the approaching elections of 1912.

But even the most radical prophets were surprised by the results, which gave the SocialDemocrats the enormous number of ilo seats. All the other more important parties lost ground, including even the Clericals. The old bloc lost 47 votes and is no longer in the majority. If the Socialists were willing to work with the Liberal Elections of 1912.

The NationalLiberals the deciding factor Left the passage of measures more favorable to the masses, among them a revision of the financial reform of 1908, would be possible, provided of course that the Bundesrat would give its consent. The National-Liberal party now holds the balance of power in the Reichstag. Although the situation is not altogether agreeable to the government, it is nevertheless much better than before 19I2. The government finds it comparatively easy to work with the National-Liberals. 


\section{GERMAN GOVERNMENT AND POLITICS}

\section{PARTY MOVEMENT AS SHOWN BY STRENGTH \\ IN THE REICHSTAG}

$1871-1912$

\begin{tabular}{|c|c|c|c|c|c|c|c|c|c|c|c|c|c|}
\hline Parties..... & '71 & 74 & 77 & '78 & 181 & 84 & 87 & 90 & 93 & '98 & 'o3 & '०7 & '12 \\
\hline Conservatives & 54 & 21 & 40 & 59 & 50 & 78 & 80 & 73 & 72 & 56 & 52 & 60 & 43 \\
\hline Free Conservatives. & 38 & 33 & 38 & 56 & 28 & 28 & 41 & 20 & 28 & 23 & 20 & 25 & 15 \\
\hline $\left.\begin{array}{l}\text { Anti-Semetics; .. } \\
\text { Agrarians. . . . . }\end{array}\right\}$ & - & - & - & - & - & - & 1 & 5 & 16 & 24 & 18 & 27 & 4 \\
\hline enter (Clericals) & $5^{8}$ & $9 \mathrm{I}$ & 93 & 93 & 98 & 99 & 98 & 106 & 96 & 102 & 100 & 104 & 93 \\
\hline $\begin{array}{c}\text { Poles, Alsace-Lor- } \\
\text { raine representa- }\end{array}$ & & & & & & & & & & & & & \\
\hline $\begin{array}{l}\text { tives, Guelphs, } \\
\text { Bavarian Farm- }\end{array}$ & 21 & 33 & 28 & 35 & 43 & 42 & 32 & 37 & 37 & 33 & 31 & 28 & 30 \\
\hline ers Union ..... & & & & & & & & & & & & & \\
\hline $\left.\begin{array}{c}\text { National Liberals } \\
\text { and Allies....... }\end{array}\right\}$ & 150 & 152 & 127 & 98 & 45 & 50 & 99 & 42 & 53 & 47 & 50 & 56 & 44 \\
\hline Liberals of the Left . & 47 & 50 & 48 & 34 & II 4 & 74 & 32 & 76 & 48 & 50 & 36 & 50 & 45 \\
\hline Democrats... & 1 & 19 & 12 & 9 & 12 & 24 & II & 35 & 44 & 56 & 81 & 43 & 110 \\
\hline Independents ..... & 28 & 8 & I I & 13 & 7 & 2 & 3 & 3 & 3 & 6 & 9 & 4 & 3 \\
\hline
\end{tabular}

\section{SELECTED BIBLIOGRAPHY}

Lichtenberger, H. "Germany and its Evolution in Modern Times," Chapter V (The German Empire and her Home Policy).

Bülow, B. von. “Imperial Germany,” Part II (Home Policy).

Lowell, A. L. "Government and Parties in Continental Europe," Vol. II, pp. 8 ff.

OGG, F. A. "The Government of Europe," pp. 229 ff. BARKer, J. E. "Modern Germany," Chapters XVIII and XIX. 


\section{CHAPTER XVIII}

GER M A N Y'S FOR EIG N POL I CY

SINCE I 87 I

CERMANY has become great through the J army. Experience has taught her through many sad lessons that, in view of its unfortunate location, the peace and glory of the Empire can be preserved only by the maintenance of a strong army. A strong military force has been the basis for Germany's foreign policy. The Septennate, ${ }^{1}$ therefore, as well as most of the subsequent military legislation is to be remembered in this connection. ${ }^{2}$

The aim of Bismarck's diplomacy was the isolation of France so that it could not think of revenge for Alsace-Lorraine. For this reason he cultivated a friendship with Austria and Russia and tried to bridge over the natural differences between these last two countries. In France Bismarck favored the republican form of government because a union between autocratic Russia and republican France seemed to him quite impossible.

In 1875 Germany experienced the first diplomatic crisis since the Franco-German War. In that year France reorganized her army. It seemed

1 Cf. p. 227.

2 See especially the reorganization of 1887 , p. 226 . 


\section{GERMAN GOVERNMENT AND POLITICS}

to the General Staff of the German army that this reform which increased the army by 144,000 men was made in preparation for the Revancbe. Two leading papers, the "Kölnische Zeitung" and the "Post," and several prominent men, among them Moltke, openly spoke of a "preventive war." Although the old Kaiser declared to the French military attaché that there was no danger of a war from the side of Germany, the French government nevertheless tried to create the impression at the courts of Vienna, London and Russia that Germany was menacing the peace of Europe. After a conference between Bismarck and Gortchakoff, that Russian statesman, who in his measureless vanity liked to pose as peace-angel, wrote to his ambassadors: "The peace is assured," 1 and France lost its artificially created nervousness.

Later on in the same year a revolt of the Christians in Herzegovina broke out. The pan-slavistic element of Russia tried to push the Russian government into a war with the Sultan, but the Russian government was justly afraid of the objection of Austria to Russia's preponderance in the Balkans. January 15,1877 , however, a secret treaty was made, stipulating that Austria would not interfere with Russia's conquests in the eastem Balkans, but that Austria should be compensated with Bosnia and Herzegovina. The

1 Bismarck, "Gedanken und Erinnerungen," Vol. II, p. 174 . 


\section{GERMANY'S FOREIGN POLICY}

Russo-Turkish War which followed ended with the peace of San Stefano. The terms of this peace would have dismembered Turkey and disturbed the European equilibrium too much in favor of Russia. England and Austria objected and a general European war was imminent. In this dangerous situation Russia asked Germany, who had only economic interests in Turkey, to bring about a compromise with the other powers of Europe. On June 13, 1878, the famous Berlin Congress was opened, in which under the leadership of Bismarck as "honest broker" the conditions of the Balkans were settled temporarily of Berlin and a European war was avoided.

By his honest work of pacification Bismarck earned nothing but ingratitude from Russia. She had expected that the great Chancellor would play the rôle of an umpire entirely in favor of Russia. But although Germany was frequently opposed to the radical desires of England and the other powers against Russia, she nevertheless did not act as the servant of Russia in her Eastern policy, and she supported Austria in her just claims to the regulation of the Serbian boundary and the possession of Bosnia. The result was an indignant letter from Czar Alexander II in which he placed Germany in the alternative of either supporting Russia completely or of breaking the old friendship between the two countries. Only Bismarck's masterful diplomacy saved Germany her valuable friendship in this crisis. First 


\section{GERMAN GOVERNMENT AND POLITICS}

of all he gave Russia to understand that a union with her was not an absolute necessity for Germany. To do this, he concluded on October 7, 1879, an alliance with Austria. The treaty German- declared that its purpose was the consolidation Austriance of peace in Europe. If, however, either power should be attacked by Russia, it was to be the duty of the other to come to the help of her ally. In case of war with other nations the stipulators were obligated to friendly neutrality. November 4, Kaiser William communicated the contents of the treaty of alliance to Czar Alexander II, emphasizing its peaceful intentions. The impression which this treaty made in Petersburg was excellent. Russia's policy towards the allied powers ceased to be commanding and aggressive, and the Czar sought to be on better terms with this strong alliance. At the same time it created again a close union between the two naturally friendly nations of Austria and Germany.

Bismarck's desire was now to continue to prevent France from carrying on a war of revenge against Germany. When therefore in 1881 the French Ambassador in Berlin asked if Germany had any objection to the conquest of Tunis by France, he replied that Germany would not interfere in French policy outside of Europe. His desire was to withdraw the attention of the French people from Alsace-Lorraine. The conquest of Tunis, regarded by the Italians as an "old African province," and settled by 20,000 Italians, drove [238] 


\section{GERMANY'S FOREIGN POLICY}

Italy to the side of the enemies of France. May 20, I882, Italy joined the German-Austrian alliance, thus creating the Triple Alliance, first for a term of five years, after 189 I for twelve years. At each successive expiration of the treaties the Triple Alliance has been renewed.

After Bismarck had successfully rebuffed Russia's arrogance, he began again to seek Russia's friendship, but on a different basis. He did everything in his power for the reëstablishment of the old sympathetic relation. In spite of the antagonism between Austria and Russia in their Balkan policy Bismarck brought about a secret treaty signed March 21, .1884, between Austria, Russia and Germany, in which the allied powers agreed to observe friendly neutrality in case of an attack from some other power. From the point of view of Russia this treaty was directed against England from that of Germany against France. This constellation of alliances was Bismarck's greatest diplomatic masterpiece after 1871. "After concluding the Triple Alliance against Russia - and France, - Bismarck accomplished the stroke of genius of getting Russia to guarantee it." ${ }_{1}$ The diplomacy of Bismarck had reached its climax; it now ruled Europe. Germany with Austria as a strong first-class ally, with two friends of the second class, Italy and Russia, was completely secure and the natural arbiter of European politics.

1 A. Tardieu, "France and the Alliances," p. I36. 


\section{GERMAN GOVERNMENT AND POLITICS}

In 1887 the "Counter-Reassurance" between the three Emperors expired, and Austria declined to renew it, because of her differences with Russia in regard to the Eastern question. Bismarck, however, succeeded in concluding at least a treaty between Russia and Germany, which guaranteed him the non-existence of a Franco-Russian alliance. Bismarck was on friendly terms with England after he had secured the African colonies for Germany against England's protest and after the Kongo Conference. When he resigned in I890, Germany undoubtedly had the hegemony in European diplomacy.

The successor of Bismarck, Count Caprivi,

$1890-$

1904.

The rise of the

Dual

Alliance and the Triple Entente destroyed in a short time the great structure erected by the first Chancellor. To what extent the young Kaiser's influence was responsible for Germany's diplomatic decline cannot yet be completely determined. It is certain, however, that he was in general the guiding spirit of German diplomacy. The first result of the "new course" was the dissolution of the intimate friendship with Russia. The government said that its reasons for giving up the Russian alliance were that the whole situation was too complicated indeed a skilful diplomat was required to handle the different alliances correctly - and that the relations between Austria and Russia had become so strained that Germany had necessarily to give up Russia in order to preserve its loyalty to Austria. Russia was without any real necessity isolated by [240] 


\section{GERMANY'S FOREIGN POLICY}

Germany. Just as needless at that time seemed to be the English friendship which Caprivi and the young Kaiser now wished to replace for that of Russia. This change in German diplomacy became clear, when Germany and England concluded a treaty on July I, I890, by which Heligoland was ceded to Germany, while the boundary line in East-Africa was settled to the great advantage of England. Many of the statesmen and political writers at that time believed that the African explorer, Stanley, was right when he said: "England received a new suit for a trouser-button," and it seemed to them as if concessions had been made to England which were unnecessary, unless the politique grande had something to do with it. To-day there is nobody who denies that this exchange was a master stroke of German diplomacy.

The immediate result of this new policy was the Franco-Russian Alliance. The idea of this alliance was not new. It had been the dream of The Dual Allance many a French statesman and in Russia it had many friends and advocates, especially Gortchakoff, and the Pan-Slavists, who were jealous of Germany and believed that a strong France was necessary for European equilibrium. ${ }^{1}$

As early as 1887 an open breach between the governments of Germany and Russia seemed

1 Gortchakoff's policy in the year 1875 had been influenced by his personal jealousy of Bismarck, and the liking felt for France by the Pan-Slavists. See Blum, H., "Bismarck und seine Zeit," Vol. VI, pp. $175 \mathrm{ff}$., and Vol. V, pp. $230 \mathrm{ff}$. 


\section{GERMAN GOVERNMENT AND POLITICS}

inevitable, and it was only avoided through Bismarck's skilful diplomacy. In the spring of that year a tariff war broke out between Russia and Germany, which created a bitter feeling in both countries. The tension was increased by the attempt of the Czar's government to Russify by force the German-Russians in the Baltic provinces. In January, I888, the Russian government asked the German Imperial Bank for a loan, which was refused. Thereupon a French syndicate offered to subscribe for the loan. The offer was accepted and in the years 1889 and 1891 other loans followed. This action showed the friendly sentiment of the French people for Russia and created a solid financial basis for the future alliance. Tardieu estimates the entire amount of Russian loans in France at twelve billion francs. The alliance between the two powers was concluded August 22, I89I. German diplomats, in the vain confidence of superiority, made the mistake of ridiculing it as a comedy and nothing but the relation of a creditor to his debtor. But they soon saw their mistake. The meaning of the creation of the Franco-Russian Alliance was that the time of Germany's hegemony was over, the balance of power was reëstablished in Europe. André Tardieu, an interesting, patriotic and at the same time sufficiently cool writer on diplomacy, says: "The Franco-Russian Alliance insured us in Europe a moral authority which, since our defeats, had been wanting to us. It [242] 


\section{GERMANY'S FOREIGN POLICY}

augmented our diplomatic value. It opened to us the field of political combinations, from which our isolation had excluded us. From mere observations, we could pass to action, thanks to the recovered balance of power." ${ }_{1}$ Prince Bülow said in 1902 to Mr. Tardieu: "The Triple Alliance and the Dual Alliance are the chief supports of the European balance of power." "This was," continues Tardieu, "implicitly admitting that until the latter was an accomplished fact, the equilibrium did not exist."

The Dual Alliance has several times shown its strength as a powerful factor in European diplomacy. Germany understood fully what $\mathrm{Mr}$. Tardieu meant, when he said: "Let us once again repeat that one has only to look at a map to be convinced that, in a Continental war, Russia alone would be able to immobilize part of our adversaries' forces - and reciprocally." 2

The period following the creation of the FrancoRussian Alliance was a time of general peace. It was, however, an armed peace. Every nation continued to increase her army. England was in general friendly to the Triple Alliance, but did not show any intention to join it. She believed in her so-called policy of "splendid isolation." The balance of power on land was not of such great importance to her as her preponderance on the ocean.

1 A. Tardieu, ibid., pp. 13-I4.

2 A. Tardieu, itid., p. 34. 


\section{GERMAN GOVERNMENT AND POLITICS}

With Prince Hohenlohe's chancellorship, Ger-

Treaty of Shimonosekt, 1895 many gradually returned to Bismarck's diplomatic principles and began to develop her world-policy fully. In the peace of Shimonoseki between Japan and China, April 17, 1895, the German envoys together with those of France and Russia protested successfully against Japan's desire to take the Liao-tung peninsula, including Port Arthur, from China. Japan was thus for the immediate future driven to the side of England and the United States. During this year began the hostility between German and English public opinion, represented especially by the newspapers, and this was increased by the telegram of congratulation which William II sent to Kruger on account of the defeat of the Jameson raid ${ }^{1}$ in the year 1896. But although England became more and more hostile to Germany, she did not show any desire to join the Dual Alliance, on account of the attitude of France towards the Egyptian question.

The close of the ninteenth century saw a steady and enormous increase of armies and navies. In 1898 and 1900 Germany passed its first naval acts showing its serious determination to enter the field of world-politics. In spite of the fact that public opinion of Germany and England grew more bitter every day, the relations of the two governments improved and were even cordial,

1 It should not be forgotten that the press of France, Russia, and the United States took the same attitude.

[ 244] 
as could be seen in the Samoa treaties, the German concessions in regard to the Cape-Cairo telegraph line passing through German EastAfrica, the strict neutrality of the German Government during the Boer War, in spite of the tremendous enthusiasm of the German people for the Boers, the Anglo-German agreement in regard to China in 1900, and the English-GermanItalian action against Venezuela in 1902-3. But now the English government began to follow public opinion at home, to approach France, and to take a hostile attitude towards Germany.

The main reason for it was England's economic jealousy. While in former times England's economic supremacy was undisputed now the rapidly expanding commerce and industry of Germany began to displace English goods in the world market. The reports of the English consuls created a tremendous excitement in the business world and among the mass of the people. As Tardieu says: "The economic menace was bound to provoke a chronic state of nervousness, which soon developed into an obsession. The English grew to think that Germany's policy was everywhere aimed against them." 1 Thus the creation of a German navy, which was officially stated not to be aimed against England directly, ${ }^{2}$ was taken as a step toward the invasion of England and the destruction of its naval supremacy. Unfortunately the Pan-Ger-

1 A. Tardieu, ibid., p. 55.

2 Cf. Chapter V. 


\section{GERMAN GOVERNMENT AND POLITICS}

man Union and press, whose policy has again and again been officially rejected, did its best to excite English public opinion and to create a wrong impression in the whole world about Germany's intentions. The power of the Pan-Germans is usually far overestimated to the detriment of Germany. ${ }^{1}$

The rapprochement between France and England was accomplished by the colonial agreement of April, 1904. According to this, France gave up her opposition to England's acquisition of Egypt and in turn France received England's support in her penetration of Morocco. This agreement settled also some other differences of minor importance. It was stipulated that the two signatories "should lend each other mutual help diplomatically for the execution of the clauses of the present declaration." Without any doubt England won more by this agreement than France. "France's adhesion to Great Britain's Egyptian policy confirmed existing situations and constituted a real profit for her, whereas in Morocco she granted to France virtual advantages, prospects and possibilities only. France paid cash down, England by draft." 2

Here begin England's attempts to isolate Ger-

1 E.g., A. C. Coolidge, in his well-known book "The United States as a World Power," gives the impression that he does not discriminate between the wishes of some extreme PanGermanists and the German people and their government.

2 Tardieu, ibid., p. 65.

[246] 
many, the so-called "policy of encirclement." Germany had consented to the Franco-English agreement as far as Egypt was concerned. For the interest of her growing commerce, however, she had insisted that the principle of the open 1905-06. Confict between Germany and the Triple Entente door should be recognized in Morocco. Since the French people showed their intention to conquer this country, which, without precautions, would have excluded or at least injured German commercial interests, the German Kaiser undertook a visit to Tangier in 1905. To the representative of the Sultan Abdul Aziz he spoke as follows: "I hope that, under the Sultan's sovereignty, a free Morocco will remain open to the pacific competition of all nations, without monopoly and without annexation, on a footing of absolute equality. My visit to Tangier is intended to make known the fact that I am resolved to do all that is in my power properly to safeguard the interests of Germany, since I consider the Sultan as being an absolutely free sovereign." 1

From these words, the spirit of which has often been repeated, Germany's position was definitely taken in opposition to the conquest of that country. France naturally resisted Germany's The
Morocco crisis of 1905 demand to have the situation fixed by an international conference. At the same time Germany demanded the dismissal of Delcassé, who, as Minister of Foreign Affairs since 1898 had tried in every way to isolate Germany. He was re-

1 Tardieu, ibid., p. 177. 


\section{GERMAN GOVERNMENT AND POLITICS}

garded by all as a constant menace to Germany. France was in a bad situation. She was entirely unprepared for a war and her only ally on the continent, Russia, was suffering defeat after defeat in her war with Japan. The French government yielded to both demands of Germany. Germany had triumphed, France had suffered a great humiliation. But instead of using her first victory and after defeating France quickly by diplomacy excluding her once and forever from the European Concert, Germany waited six precious months. By that time the situation had changed entirely. France had prepared herself for a war; Russia had recovered a little from her defeat, and was ready to come to the help of France; Spain was drawn closer to France; and England joined the other allies of France.

The Conference of Algeciras

German diplomats in addition to their former mistake made another by not recognizing this change and by acting as if they were the masters. Their proposals were in general not extreme; they were as follows: sovereignty and independence of the Sultan; the integrity of his country; economic liberty without inequality; the utility of police and financial reform, the introduction of which should be regulated for a short period by international agreement. France made her counter proposals. The organization by France and Spain of an international police in Morocco was opposed by Germany, but she had to yield to the demands of France and her allies. Germany had [248] 
overestimated her strength. Of the more important powers only Austria assisted her, while even Italy voted with her enemies. Germany, however, had no reason to blame Italy, as the Moroccan question was not one of the articles of the Triple Alliance but a question of the Mediterranean, and Germany had always refused to support Italy in her Mediterranean policy simply because of the existence of the Triple Alliance. ${ }^{1}$ Therefore Italy who wanted to secure the consent of France for the imminent acquisition of Tripoli, had a right to act in disharmony with Germany. Nor did the position which Italy took in the Morocco question really reflect her attitude towards the Triple Alliance, for, as said before, this question was not one of the Alliance.

The German government and the people looked at the Morocco question from two points of view. As Prince Bülow said: "In the incidents which have arisen during the past six months or so, there are two distinct things to consider. Morocco is the first; general policy is the second. In Morocco we have important commercial interests; we intend and we shall still intend to safeguard them. In a more general way, we were obliged to reply to a policy which threatened to isolate us and which, in consequence of this avowed aim, assumed a distinctly hostile character with regard to us. The Moroccan affair was the

${ }^{1}$ We agree in this regard with A. Tardieu, "La Conférence d'Algésiras," pp. 61-62. 


\section{GERMAN GOVERNMENT AND POLITICS}

most recent and most clearly manifested example of such policy. It furnished us with an opportunity to make a necessary retort." 1

The following two years, 1907 and 1908, showed From the partial success of the attempts to isolate 1906 to

the outbreak of the Germany. She was disliked all over the world. European War She had again - on account of her military strength - the respect of everybody, but the love of nobody. The "Daily Telegraph" affair ${ }^{2}$ increased the universal distrust of Germany and her Kaiser. Naturally the German government more than ever before refused to discuss vague plans of disarmament, which were proposed all over the world. On the contrary Prince Bülow declared in the Reichstag that "Germany's armaments will be kept so strong that no power or coalition of powers shall care to come into conflict with her."

At the end of 1908 Austria-Hungary annexed Austrian Bosnia-Herzegovina, and found in doing so strong annexation of BosniaHerzegovina support from Germany against Russia, who tried to back the Pan-Serbian demand of compensation for these two provinces. Russia finding no support from her allies and threatened with war by Germany, finally had to withdraw her support from Serbia, who alone was powerless. This affair improved the diplomatic prestige of Ger-

1 A. Tardieu, ibid., p. 190. Prince Bülow in a private interview with the author.

${ }^{2}$ See pp. 93 ff.

[250] 


\section{GERMANY'S FOREIGN POLICY}

many and showed the lack of cohesion in the Triple-Entente.

In 1909 an agreement in regard to Morocco was reached between France and Germany, by which Germany recognized the special political interests of France in Morocco, while France pledged herself to respect Germany's commercial and industrial interests in Morocco.

The year 1910 was a quiet year. In Asia the final partition of Persia between England and Russia began. As long as her economic rights were observed, Germany had no interest there. ${ }^{1}$ However, the economic interests of Germany in Turkey and Persia were very great, especially on account of the Bagdad railway scheme. In I899 Turkey, and a society controlled by German money (the Société du cbemin de fer Ottoman Rallway d'Anatolie) concluded a contract which granted this company the right to build a railroad between Konia and Basra through Bagdad within eight years. The building of the railroad was started in 1902. Now German capital which already before had been interested in Turkish enterprises began to come in more and more. The ties which bound Turkey to Germany became stronger and stronger. As far back as $188_{3}$ German generals had drilled the Turkish army. Turkish military and civil officers were trained in Germany. In

1 Bülow, on April 30, 1907, had said in the Reichstag: "In Persia Germany only claims freedom of movement in the commercial sense, without any political arrière pensée. 


\section{GERMAN GOVERNMENT AND POLITICS}

1898 the German Kaiser visited Constantinople and Palestine and it was in Damascus that he assured "His Majesty, the Sultan, and the 300, Germany 000,000 Mohammedans, scattered about the Ottoman earth" that "at all times the German Kaiser is Empire their friend." The Turkish government and the people of Turkey had come to realize that Germany alone of all European powers had solely economic interests in territory inhabitated by Mohammedans, and that Germany was their most dependable friend against Russian and English territorial aggressions. Germany's interests in a strong Asiatic Turkey had become so great that Bismarck's words, "that the whole Oriental question was not worth the sound bones of a single Pomeranian grenadier" were true no longer.

Since the partition of Persia could not be Potsdam stopped, Germany by the "Convention of PotsConvention dam," recognized the Russian influence in North Persia; while Russia promised not to hinder the building of the Bagdad railway. This agreement for a time improved the relations between Germany and Russia. The animosity between England and Germany, however, increased in spite of many efforts on both sides to improve the relations existing between the two countries.

In I9I I France proceeded in her conquest of Morocco, marching to $\mathrm{Fez}$ and thus violating the Algeciras conference. Germany, being afraid of losing everything, sent a gunboat to Agadir [252] 


\section{GERMANY'S FOREIGN POLICY}

after she had in vain demanded compensations for her rights in Morocco. The Chancellor von Bethmann-Hollweg explained in the Reichstag as Second Morocco crisis the aim of his action: "To show the world that Germany was firmly resolved not to be pushed aside." Western Europe was excited, war seemed imminent. But finally France and Germany came to an agreement, and two treaties were signed on November 4 . In the first treaty Germany recognized France's protectorate in Morocco while France recognized the principle of the open door. The second treaty gave Germany a compensation in French Kongo, while France received a new rectification of her boundary lines with the German Kamerun and a small cession of territory. People in France and in Germany were equally dissatisfied with these treaties; the French critics claimed that Germany was not entitled to any compensation, German critics on the other hand insisted that the compensation was not equivalent to the German loss. The German people were above all enraged against Great Britain, who had once more fully supported France.

The opinion of a minority of the more quiet people and of those who, for the sake of peace, believed in concessions, was expressed by the Chancellor in the following words spoken in the Reichstag: "The peaceful settlement of the Moroccan question was an enormous gain, and as England was bound by treaty to support France in all differences with Germany about 


\section{GERMAN GOVERNMENT AND POLITICS}

Morocco, the settlement cleared the ground as regards relations with England also."

Indeed a dangerous cloud on the political horizon of Europe disappeared with the settlement of the Morocco question. Unfortunately the calculation of many German diplomats that France would from now on be satisfied with the conquest of her enormous African Empire and forget the

Revival of the questlon of AlsaceLorraine

Balkan Wars

Italian selzure of Tripoli loss of Alsace-Lorraine proved wrong. The middle of the year 1913 witnessed again a revanche excitement in France similar to the chauvinism of the eighties, and warned the German people to continue their watch on the Rhine.

When in the year 1913 Germany celebrated the twenty-fifth anniversary of the reign of her Kaiser, she could look with pride upon her peaceful record since 1870 . "Without boastfulness or exaggeration she could say that never in the course of history has any power possessing such superior military strength as the Germans served the cause of peace in an equal measure." 1

The relations between Germany and England began at last to improve and it was mainly due to the harmonious effort of these two countries that during the Balkan wars of $1912-13$ the peace of the rest of Europe was preserved.

At the end of the year I9I I Italy suddenly seized Tripoli upon legal claims dating back as far as the Crimean war, in fact however, because she saw the necessity of providing a colony for

1 Prince von Bülow, "Imperial Germany," p. 48. 


\section{GERMANY'S FOREIGN POLICY}

her large emigration and her future over-production, and because she was justly afraid that Tripoli with her menacing position opposite Italy might some day be taken by the French as Tunis had been taken before.

Before this war could be fought out Turkey had to conclude peace and give up Tripoli because the newly formed Balkan League, consisting of Bulgaria, Serbia, Greece and Montenegro, declared a war against Turkey which ended in Turkey's complete defeat. The war among the members of the League themselves resulting from difference of opinion in regard to the distribution of the booty, left Turkey in possession of a small but very important territory in Europe, including Adrianople and Constantinople. It was Germany's interest to see the war ended as soon as possible and to see Turkey keep the keys of the Dardanelles. In this regard her wishes concurred with those of England and thus the two governments coöperated to localize the war. England also helped Austria in the creation of the artificial Kingdom of Albania, thus excluding Serbia from a part in the Adriatic Sea. One of the results of the Balkan war was the stimulation of Pan-Slavism. The Russian government began now more than ever to act as the promoter of Pan-Slavistic ideals, ${ }^{1}$ with the help of which

1 On the other hand the German government has repeated again and again that the ideals of Pan-Germanism were not identical with those of the government, that "the course of 


\section{GERMAN GOVERNMENT AND POLITICS}

she expected to secure the leadership in the Balkans and finally realize her long desired wish for the possession of Constantinople and the Dardanelles. While the relations between England and Germany improved very much, the animosity between Russia and France on the one hand and Germany on the other hand grew from day to day. Europe was completely undermined. Responsible authorities and friends of peace tried their best to give nobody a chance to light the match which would bring the mines to a general explosion. But in vain! Suddenly in July, I9I4, the explosion took place. A fanatic Serb assassinated, at Serajevo, Bosnia, the Crown Prince of Austria-Hungary, Archduke Franz Ferdinand, and his wife. In August nearly all EuropeGermany and Austria, later on Turkey as one party, Russia, Serbia, England and her colonies, France, Belgium, with Japan as an Asiatic ally, and Italy, as the other party - was plunged in to the most terrible war which modern history has seen.

According to R. V., Article 11, the Kaiser Central alone has the right of representing the German
organlzation of foreign affairs Empire in its international relations. He declares war and peace (with the consent of the Bundesrat) concludes alliances and treaties, accredits and receives diplomatic representatives

Germany's foreign policy would lie between the parochial wishes of Social-Democracy and the extravagant desires of the Pan-Germans."

[256] 
of foreign nations. As far as the international treaties affect German citizens directly, they need for their validity the consent of the Bundesrat and Reichstag.

The central administrative organ for the foreign affairs of the Empire is the Auswartige Amt or Foreign Office. It was taken over by the Empire from Prussia and is now conducting the affairs of both states. The Foreign Office is divided into three departments:

I. The Department of Politics and the Personnel.

2. The Department of Commercial Politics.

3. The Department of Law.

Directly under the Chancellor are the "Commission for the Examination of Diplomatic Officers" and the "Archaeological Institutions in Rome and Athens."

The Kaiser alone has the right of appointing the diplomatic officers of the Empire. Some of the states have still a few diplomatic officers at foreign courts, who, however, are of no real importance in political affairs. They also receive diplomats from these states. All the diplomatic officers of the German Empire have to take a full law course and pass an examination before they are admitted to this branch of the civil service of the Empire. The great majority of them belong to the wealthy aristocracy.

The Empire has all the four classes of diplomats existing under the rules of international law:

Diplomatic service 


\section{GERMAN GOVERNMENT AND POLITICS}

ambassadors (at present 9), ministers (17), minister residents and chargés d'affaires.

The commercial representation of the Empire Consular abroad, i.e., the consular service, is completely service in the hands of the Empire. All the consuls are Imperial civil service officers appointed by the Kaiser after the consultation of the Bundesrat (R. V., Article 56). There are consules electi or honorary consuls and consules missi or professional consuls. Of the latter category there exist three classes: consuls-general, consuls, and vice-consuls. The consuls may appoint special consular agents as their assistants. The consuls are judicial officers in a number of cases of non-contentious jurisdiction. ${ }^{1}$

By special treaties of extra territoriality consuls may act as judges in civil and criminal cases (for example in China and Persia).

Appeals from their jurisdiction lie to the Reichsgericht.

\section{SELECTED BIBLIOGRAPHY}

YEAR BOOKs:

Schiemann, Th. "Deutschland und die grosse Politik." Since 1900 .

Annual Register. Since $175^{8}$.

"La vie politique dans les deux-mondes." Since 1906. Rose, F. H. "The Development of the European Nations, I870-1900," Vol. I, Chapter VI; and Vol. II, Chapter I.

Onken, H. The German Empire. In "Cambridge Modern History," Vol. XII, Chapter VI. 


\section{GERMANY'S FOREIGN POLICY}

Bismarck, Otro von. "Reflections and Reminiscences," Vol. II, Chapters 28-30.

voN Bülow, BeRnhard. "Imperial Germany." r: Foreign Policy.

Reinsch, P. S. "World Politics," Chapter IV, (German Imperial Politics).

Crispi, Francesco. "The Memoirs of Francesco Crispi." 3 vols.

Wertheimer, E. von. "Graf Julius Andrassy." 3 vols.

Broglie, Duke DE. "An Ambassador of the Vanquished." Viscount Elie de Gontant-Biron's Mission to Berlin, $1871-1877$.

Hanotaux, G. "La France vivante"; English translation, "Contemporary France." 4 vols.

TARDIEU, ANDRÉ. "France and the Alliances." 


\section{CHAPTER XIX}

THE COLONIAL DEPENDENCIES

V

ERY late, when the process of colonial acquisition was almost complete, Germany The began to seek for colonies. Even then the tion of the dependencles government was hesitating and cautious. It was mainly due to the encouragement of University teaching and the energetic activity of a handful of merchants and private persons, that the German government acquired its first colonies.

Before the foundation of the new Empire, only two unsuccessful attempts at oversea colonization had been made by Germans, ${ }^{1}$ although they had frequently shown splendid qualities as colonists in the possessions of other powers.

During the first years of its existence, the new German Empire was too much occupied with its inner organization to think of colonies. About I880, German university professors, undoubtedly the most powerful factors in the creation of Germany's public opinion, began to demand the acquisition of colonies, but for a long time it remained an academic question. The mass of the

1 In the beginning of the r6th century by the merchanthouse of the Welsers in Augsburg under the protectorate of Charles V, and in 1683 by the Great Elector of Brandenburg, Frederick William.

[260 ] 


\section{THE COLONIAL DEPENDENCIES}

German people was not yet in favor of a colonial policy; and without the backing of general public opinion Bismarck did not wish to enter upon a course, the end of which might have been unfortunate for Germany. The first cautious attempt he made toward the initiation of a colonial policy was discouraging. In 1880 he proposed to subsidize a German colonial company in Samoa, but the Reichstag refused its consent. From that moment public opinion grew rapidly in favor of colonies thanks above all to the missionary work of the German Colonial Club, the Deutscher Kolonialverein, founded in 1882,1 and since 1887 known as the German Colonial Society, Deutsche Kolonialgesellschaft.

Several reasons quite naturally led Germany to the attainment of colonies. Many millions of citizens had been lost by Germany through emigration before $187 \mathrm{I}$. Between $187 \mathrm{I}$ and 1880 the Empire lost 625,656 , of which number 555,866

Arguments in favor of colonial possessions went to the United States; between I88I and 1890 there were $1,333,681$ emigrants, $1,232,486$ of these to the United States; and between 1891 and I90I, 551,948 emigrated, out of which number 478,129 went to the United States. More than 2,500,000 therefore were lost to the fatherland between $187 \mathrm{I}$ and I901. These emigrants were far from being

1 Its first president was the prince of Hohenlohe-Langenburg. In 1887 this club and another large colonial society, the Gesellschaft für deutsche Kolonisation, united to form the Deutsche Kolonialgesellschaft. 


\section{GERMAN GOVERNMENT AND POLITICS}

undesirable elements. They were mostly young men who had received a good school education, enterprising, industrious peasants. Such a loss of productive population was to be regretted extremely by the German government, and it was from its point of view highly advisable to acquire colonies to which the stream of German emigrants could be directed, where they could keep their German nationality and be useful for the promotion of German interests.

With the rapid development of commerce and industry in Germany, it became necessary to look for wider markets. The tendency to exclude foreign nations from the home market by high protective tariffs was, and is still, growing everywhere. It is uncertain how long England will stand by her principle of free trade. Already special agreements exist between Great Britain and her colonies favoring the products of each other. So it has appeared very advisable for Germany to find secure markets. Furthermore, home industry needs an enormous amount of raw products for fabrication. In 1906, Germany imported 445 million marks' worth of cotton, 372 million marks of wool, 228 of copper, 170 of coffee, 170 of cow-hides, 77 of sheep and goat hides, 149 of rubber and guttapercha, 63 of copra, palm-oil, etc., $4 \mathrm{I}$ of cocoa. A small percentage of these products is now imported from the German colonies, and the production of these materials in the colonies is [262 ] 
steadily increasing, so that some time in the future a considerable amount of these raw materials may be imported from German territory, the wealth of the nation as a whole increased, and industry at home made independent of monopolies and trusts abroad.

The acquisition of the first German colony was due to private initiative. In the year 1883 the merchant Lüderitz from Bremen made treaties with native chiefs in South-West Africa, around Walfish Bay. The first opposition to this colonization came from its English neighbors in the Cape Colony. England herself was indifferent to it and did not raise serious objections. In the first place there was a general feeling at that time all over Europe against colonies. Mr. Gladstone who was prime minister at the time, himself knew and cared little about colonial affairs. Furthermore, nobody took Germany's colonial attempts seriously. And above all, England was at that time weak in international politics. To France she was hostile on account of her Egyptian policy, and with Russia she was on bad terms because of Afghanistan.

If Germany were ever to obtain colonies now was the appointed time. Bismarck proceeded deliberately and openly. "He conducted the game with the admirable foresight of a consummate chess-player, who sees, far ahead, what will be the effect of any particular move." 1

${ }^{1}$ Keltie, J. S., "The Partition of Africa," p. 178. 


\section{GERMAN GOVERNMENT AND POLITICS}

On April 24, 1884, German South-West Africa was made a protectorate in spite of feeble English protests. Only three or four months later the famous African explorer Nachtigall, as the representative of the German Empire, made treaties with some native chiefs in Togo and Kamerun. Again the English government showed itself totally indifferent to the requests of those chiefs who desired a British protectorate rather than a German. England's later protests were therefore absolutely unfounded. The English colonial writer, Mr. Keltie, says correctly: "We may congratulate ourselves that we have not fared worse than we have done, for we did our best to deserve worse." 1 The revolt of the natives which, under English influence, broke out immediately after the taking of Kamerun, was quickly suppressed by two German men-of-war.

In the same year, I 884 , Germany took possession of her largest colony in Africa, German East-Africa. Dr. Peters made treaties in November, I 884 , with a number of native chiefs on behalf of the "Society of German Colonization." This company was replaced by the German EastAfrican Society, to which in February, I885, a letter of protection was granted by the German Empire. The Sultan of Zanzibar objected to the German occupation, but after a demonstration of the German fleet he yielded to German superiority. In the year I 888 a dangerous rebellion 1 J. S. Keltie, "The Partition of Africa," p. 190. [ 264] 


\section{THE COLONIAL DEPENDENCIES}

under the leadership of the Arabs broke out, which was put down in 1889 . In 1890 the company sold its rights to the Empire for 600,000 marks.

England's consent to the taking of East-Africa was easily obtained. After the downfall of the Ferrier ministry in France which had been very friendly to Bismarck's policy and which on the other hand had gained much by this friendship, Bismarck sent his son Herbert to England to create a better understanding with that country. Gladstone gladly accepted the offer made to him, because he badly needed a strong friend in international politics. He recognized Germany's need of colonies and promised her every encouragement for her work of colonization.

In the year I 884 the German part of New Guinea, and in 1885 the Marshall Islands, both in the South Sea, were taken by occupation.

An attempt of Germany to take the Carolines by occupation met with Spain's opposition. The dispute was submitted for arbitration to the Pope, who decided in favor of Spain. Germany was given only a coaling station. In the year 1899, after the Spanish-American war, Spain sold the Caroline, and Palaos, and Marianne Island groupes (except Guam), to Germany for $16 \frac{2}{3}$ million marks. In the same year (1899) the constant troubles in Samoa which had lasted for ten years and had unduly excited public opinion in Germany and the United States, were settled 


\section{GERMAN GOVERNMENT AND POLITICS}

by the partition of these islands. Germany received the two largest islands, Upolu and Savaii, and two other small islands.

The only German territory in Asia, Kiao-chau, was taken from China in 1897 in the form of a ninety-nine years' lease. The pretext for taking it was the murder of German Catholic missionaries.

It was only with great hesitation that Bismarck

The colonial policy after the acquisIthon of the dependencles had inaugurated the colonial policy of Germany, which led in so short a time to the foundation of an important colonial empire. He never became a great enthusiast for colonies - as late as I 899 he declared that he was "still no colony man." The basis of sound colonial policy was for him the backing of the majority of the people. In I 884 he said in the Reichstag: "In order to be able to carry on a colonial policy successfully a government must have behind it in Parliament a solid majority national in sentiment, a majority which is superior to the momentary decline of individual parties. Without such a reserve of force in the background we cannot carry on colonial policy." In the first years of colonization enthusiasm was very great. But it lasted only a short time. The colonies complicated Germany's position in world politics; they involved the country in an enormous expenditure, and they cost the country hundreds of precious lives. Punitive expeditions had to be carried on constantly against native chiefs. In South-West Africa long-lasting wars had to be undertaken [266] 


\section{THE COLONIAL DEPENDENCIES}

against the natives. The great Herrero campaign, which ended in 1906, alone cost the lives of 90 officers and I,321 men, besides 907 wounded. Moreover, the administration of the colonies was extremely bad. On October 28, 1885, Bismarck had said in his famous colonial speech in the Reichstag: "My aim is the governing merchant and not the governing bureaucrat in those regions. Our privy councilors and expectant subalterns are excellent enough at home, but in the colonial territories I expect more from the Hanseatics who have been there." Unfortunately this principle was not consistently applied to the colonial administration. One scandal after another occurred, so that in 1906 Prince Hohenlohe retired, utterly disgusted, from the presidency of the Colonial Department of the Foreign Office. Nearly everybody in Germany was discouraged and apathetic.

Then came the refusal of the Clericals to grant the necessary amount for the termination of the rebellion in South-West-Africa. All at once the people awoke. The government, under the leadership of Dernburg, who later on became Secretary of the newly created Colonial Office, aroused the greatest colonial enthusiasm Germany had ever experienced. Severe but healthy self-criticism set in, and the whole colonial service and the methods of colonization were revised. Dernburg cleansed the Augean Stables of colonial administration. He replaced the bureaucrats with men 


\section{GERMAN GOVERNMENT AND POLITICS}

of common sense and open minds. His principles were based on experience, comparison with other countries and business methods. "Colonization," he said, "is a science and technique just like the rest; it must be learned not only in the lecture room, in legal practice, and in the counting house, but by studying the needs and conditions of foreign lands on the spot, and by the application of all the auxiliaries which science - and above all the science of our neighbors affords."

With Dernburg, German colonies entered a new development. The fundamental faults have been corrected, the German people have regained confidence in their ability as colonizers, general interest is taken in the colonies by all national parties, and slow but steady progress is being made.

The Germans have made many bad mistakes in the management of their colonial affairs, but it must be considered that they were entirely inexperienced, and they have shown willingness to learn. They believe now in Dernburg's ${ }^{1}$ opinion, that the colonies are "a great Imperial concern which cannot prosper without a powerful impulse, without the coöperation of the noblest and best elements in the nation."

The central control over the colonies is exercised by the Colonial Office, the Reichskolonialamt, created April I, 1907. Formerly it was a part

1 It might be added that Dernburg resigned in 1910.

[ 268 ] 


\section{THE COLONIAL DEPENDENCIES}

of the Foreign Office, but with the growth in importance of the colonies the creation of a special office became necessary. At the head of the office is a Secretary of State, with the right of acting as a responsible substitute of the Chancellor. The AdminIstration of the colonies in Germany Colonial Office is divided into the Department of Civil Administration and the Department of Military Administration. The Civil Department is subdivided into divisions for general administrative, financial and technical matters. Advisory commissions are formed of experts, officials, professional travelers, professors, etc., to furnish information for the office.

Germany has no colonies within the temperate zone peopled or capable of being peopled by Europeans. Its colonies, or protectorates, except for Territory of the some scattered islands in the Pacific, and Kiaochau, are situated in tropical Africa. Besides the territories which are full protectorates ${ }^{1}$ of the German Empire, there are in addition large "spheres of interest." These are territories reserved by treaties for future occupation.

The protectorates are incapable of sustaining international relations. They are represented for such purposes by the German Empire. Reciprocally no other nation may interfere in the affairs of the protectorates. An attack upon them is an attack upon the Empire. On the other hand the protectorates are not members of the Empire

1 The word Schutzgebiete, "protectorates" is used by Germans to include all their colonial dependencies. 


\section{GERMAN GOVERNMENT AND POLITICS}

within the meaning of the Constitution. Its regulations are not eo ipso applied to the colonies. Neither are the laws of the Empire, unless specifically stated to be so, valid in the protectorates. Thus the protectorates are not in a customsunion with the mother country.

The subjects of the colonies are classified into

The subjects in protectorates
The organization of government citizens of the Empire, natives, and other subjects.

German citizens are treated like German citizens in those parts of the world where European nations have by treaty the right of extra-territorial jurisdiction. They are judged according to the rules of consular law and of the fundamental law for the protectorates. ${ }^{1}$ The natives are by treaties subject to their own laws as far as those laws are not entirely opposed to humanity. The Empire has supreme supervision over their administration. Other colored races, except the Japanese, negroes who are citizens of a civilized country, and certain superior colored races, are treated like the natives.

The first sentence of the fundamental law for the protectorates says: "The protective authority is exercised by the Kaiser in the name of the Empire." The Kaiser is, as Protector, an organ of the Empire, and his acts in regard to the colonies require the counter-signature of the Chancellor. Unless specifically limited by laws of the Empire, he need not ask the Bundesrat or the Reichstag for-advice or consent in regard to ordinances.

1 See Schutzgebietsgesetz, of September ro, 1900. [270] 


\section{THE COLONIAL DEPENDENCIES}

Except in judicial matters to which the rules of consular jurisdiction apply, the Kaiser is unlimited in his sphere of action in the protectorates. The colonial officers are subject to the same regulations as other Imperial officers.

At the head of each protectorate is a governor. All civil officers, and in Africa the military forces also, are subject to his authority. An extensive

Local adminisordinance power has been delegated to him. ${ }^{1}$ Since 1903 there have been instituted advisory councils (Gouvernementsräte) consisting of higher officers and at least three lay members, inhabitants of the colonies. The official members must not outnumber the lay element. Each colony is subdivided into districts (Amtsbezirke). At the head of each district is a district-superintendent (Bezirksamtmann), who has a similar position to the Regierungepräsident in Prussia. He is assisted by colleagues technically trained in forestry, agriculture, education and mining. ${ }^{2}$ In SouthWest Africa some beginning has been made in local self-government. The Chancellor may unite several villages into communes (Kommunalverbände), which have the character of public corporations, endowed with rights and duties.

1 Schutrgebietsgesetz, Paragraph 15, 3.

2 In some less developed parts there exist administrative organizations of minor importance than the districts, so e.g. in South West-Africa the Districtämter with the Districtchef, in Kamerun, Togo and New Guinea, the Station with a Stationsleiter. In Kamerun and East-Africa there exist also residents, i.e. advisers to chiefs of natives. 


\section{GERMAN GOVERNMENT AND POLITICS}

Cases in which persons other than natives are

The judiciary in the colonies the parties are, as we have seen, judged according to the law of consular jurisdiction and Imperial ordinances. There are two courts of appeal. The judges are appointed by the Chancellor. In most cases where at home a jury would be necessary, four adjuncts are associated with the judge for trial. Each protectorate has at its capital a court of appeal consisting of a higher judge and four adjuncts. Since 1897 each protectorate has also a public prosecutor. In cases of administrative law, the Bundesrat is the court of first and last instance.

The courts for natives are organized by ordinance of the governor. In Kamerun less important cases are settled by the native chiefs, and the more important matters are decided by special courts consisting of natives. In Togo the native chiefs are judges of first instance, except in criminal cases, which are judged by the district-superintendent. The governor is the final judge. In South-West Africa the district-superintendent and district-chief are the judges of first instance, while appeals lie to the high-judge of the colony. The natives, however, can be asked for their opinions. They must be consulted in disputes between white and colored people. In East-Africa the first judge in civil cases is the district-superintendent, with the advice of a native judge, the wali and colored adjuncts may be asked for their opinion. The high-judge of the colony is the [272] 


\section{THE COLONIAL DEPENDENCIES}

court of appeal. In New Guinea the natives do not participate in judicial matters. In the islands of the South Sea, civil cases are judged by chiefs or by the communal courts of the natives.

East-Africa, South-West Africa and Kamerun have military forces (Schutztruppen). The commander-in-chief is the Kaiser, who delegates the command to the governor of the colony. The actual military head is a German officer of higher rank. The officers and non-commissioned officers are taken from the German army at home. The common soldiers in South-West Africa are white men, citizens of the Empire; in East-Africa and Kamerun they are natives. The police troops in the other colonies are a part of the civil government. In Kiao-chau there is a garrison of marines.

The budget for each colony is first prepared by the governor with the help of his official corps. It is then sent to the Imperial Secretary of FiFinances of the nance, and thence to the Bundesrat. With the coöperation of the Reichstag it is passed and published as an Imperial law. The income of the protectorates consists mainly of tariff duties, laid upon most imports, except in South-West Africa and New Guinea. In South-West Africa and New Guinea duties are laid only on certain objects, particularly liquors and tobacco. Taxes are laid upon the natives in some colonies in the form of a head or hut tax. These primitive taxes are very low, e.g. in East-Africa four marks a year from each

Mulitary organizathon 


\section{GERMAN GOVERNMENT AND POLITICS}

hut. Similar taxes are levied in East-Africa, Kamerun and New Guinea.

With the exception of Togo, none of the German protectorates are as yet self-supporting, although the subsidies of the Empire are not extremely high and are, barring extraordinary expenses, decreasing from year to year.

The Schutzgebietsgesetz guarantees freedom of The religion in the German protectorates. The competition between the different denominations confuses the simple minds of the natives and it would be desirable, at least for the immediate future, to fix the spheres of interest between the different missionary societies. Catholics and Protestants have about the same number of baptized natives, taking all the colonies together.

\section{SELECTED BIBLIOGRAPHY}

KELleR, A. G. "The Beginnings of German Colonization" (Yale Review X).

Keller, A. G. "The Colonial Policy of the Germans" (Yale Review X).

Dawson, W. H. "The Evolution of Modern Germany" (Chapters XVIII and XIX).

Johnston, H. "The Colonization of Africa."

KeLtie, J. S. "The Partition of Africa."

Veritas. "The German Empire of Today" (Chapters VII and VIII). 


\section{APPENDIX}

AREA AND POPULATION OF GERMANY

(Census of December I, 1910)

\begin{tabular}{|c|c|c|c|}
\hline & $\begin{array}{c}\text { Area } \\
\text { Sq. M. }\end{array}$ & Total Pop. & $\begin{array}{c}\text { Pop. per } \\
\text { Sq. M. }\end{array}$ \\
\hline \multicolumn{4}{|l|}{ KINGDOMS } \\
\hline Prussia.. & 134,616 & $40,163,333$ & 224.0 \\
\hline 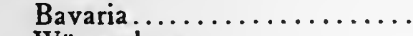 & 29,292 & $6,876,497$ & 234.4 \\
\hline Würtemberg.............. & 7,534 & $2,435,6$ I I & 223.2 \\
\hline 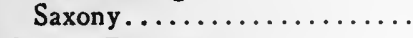 & 5,789 & $4,802,485$ & 829.5 \\
\hline \multicolumn{4}{|l|}{ GRAND DuchIES } \\
\hline 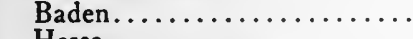 & 5,823 & $2,141,832$ & 367.9 \\
\hline 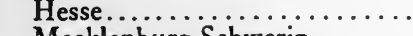 & 2,966 & $1,282,219$ & 439.0 \\
\hline Mecklenburg-Schwerin ........ & 5,068 & 639,879 & 126.2 \\
\hline $\begin{array}{l}\text { Saxe-Weimar-Eisenach } \ldots \ldots \ldots \\
\text { Mecklenburg-Strelitz. . . . . }\end{array}$ & $\begin{array}{l}1,397 \\
I, 13 I\end{array}$ & $\begin{array}{l}417,106 \\
106,347\end{array}$ & $\begin{array}{r}298.6 \\
93.8\end{array}$ \\
\hline 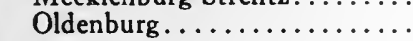 & $\begin{array}{l}1,1,31 \\
2,482\end{array}$ & $\begin{array}{l}100,347 \\
482,430\end{array}$ & $\begin{array}{r}93.8 \\
194.3\end{array}$ \\
\hline \multicolumn{4}{|l|}{ Duchies } \\
\hline Brunswick. & 1,418 & 494,387 & $34^{8.6}$ \\
\hline Saxe-Meiningen. & 953 & 278,792 & 291.5 \\
\hline Saxe-Altenburg... & 511 & 247,208 & 337.0 \\
\hline Saxe-Coburg-Gotha. & 764 & 216,313 & $423 \cdot 3$ \\
\hline Anhalt...... & 888 & 331,047 & 373.9 \\
\hline \multicolumn{4}{|l|}{ Principalities } \\
\hline Schwarzburg-Sondershausen... & 333 & 89,984 & 270.2 \\
\hline Schwarzburg-Rudolstadt...... & 363 & 100,712 & $277 \cdot 5$ \\
\hline Waldeç..... & 433 & 61,723 & 142.5 \\
\hline Reuss Ältere Linie & 122 & 72,616 & 595.2 \\
\hline Reuss Jüngere Linie & 319 & 152,765 & 478.9 \\
\hline Schaumburg-Lippe. . & 131 & 46,650 & 352.5 \\
\hline Lippe........ & 469 & 150,749 & 321.4 \\
\hline \multicolumn{4}{|l|}{ Free Cities } \\
\hline Lübeck... & 115 & 116,533 & $1,013 \cdot 3$ \\
\hline Bremen... & 99 & I 50,3 I 7 & $3,017.6$ \\
\hline Hamburg. & 160 & I,OI 5,707 & 6,973.I \\
\hline ALsace-LoRraINE & 5,604 & $1,871,702$ & 333.9 \\
\hline German EMPIRE. & 208,780 & $64,903,423$ & 310.4 \\
\hline
\end{tabular}




\section{GERMAN GOVERNMENT AND POLITICS}

\section{COLONIES AND DEPENDENCIES (1913)}

(The estimates are necessarily vague)

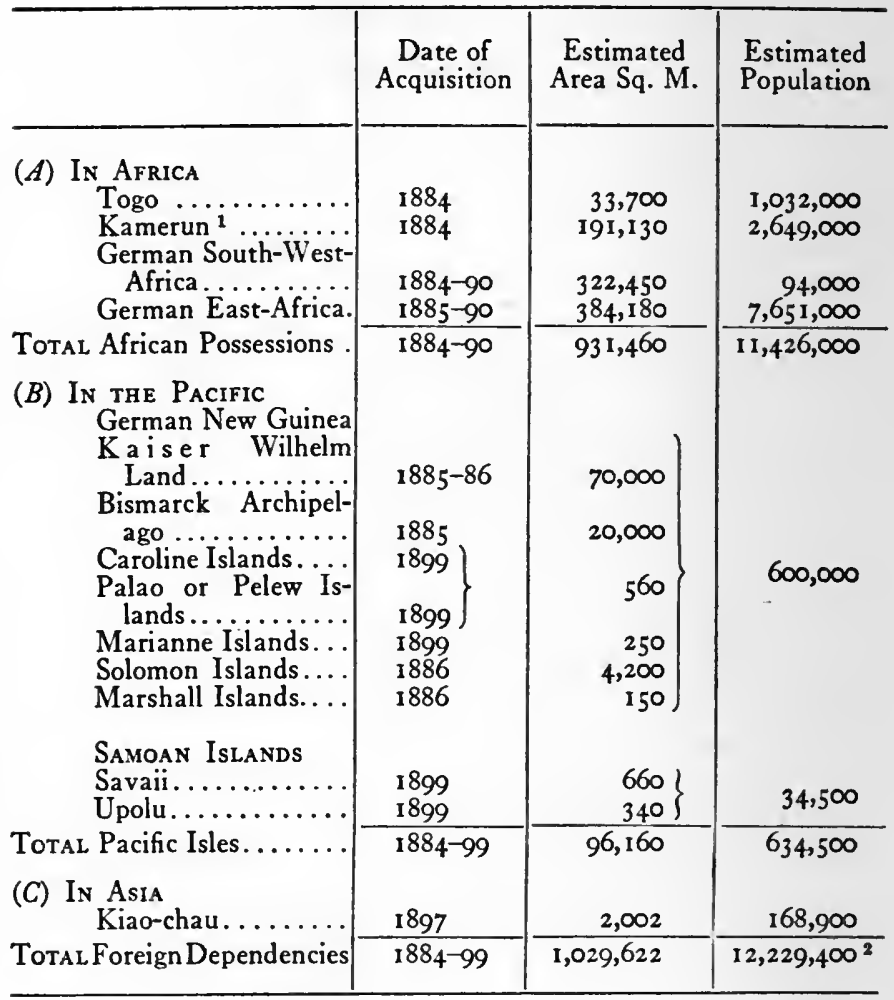

${ }_{1}$ 19I I France conceded 107,270 square miles with a population of $\mathbf{I}, \infty 00, \infty 00$ to Germany, and Germany 6,450 square miles to France. These are not counted.

2 In $1913,24,000$ of these were whites. 


\section{CRITICAL BIBLIOGRAPHY}

A CCORDING to the general principles of $A$ this collection of books on government, there are as few footnotes as possible contained in this volume. Therefore a critical bibliography at the end seems necessary. It is planned for the student interested in special topics, and also for the university instructor who is not a specialist in German government, and therefore not familiar with its literature. There does not exist in English any good bibliography on German government. Prof. A. B. Hart, in his "Introduction to the Study of Federal Government," enumerates many books and articles without critical discrimination. An excellent article on the more important German writers of German constitutional and administrative law is $\mathrm{Ph}$. Zorn's article, "Die Entwicklung der Staatsrechtswissenschaft seit 1866 " in the "Jahrbuch des öffentlichen Rechts der Gegenwart," Band I, Tübingen 1907. Another valuable source of information is Landsberg, E.: "Geschichte der deutschen Rechtswissenschaft," 3 Abteilung. München und Berlin, 1910. Prof. G. E. Howard's "Comparative Federal Institutions," gives a small analytical reference syllabus, which is also recommended. 


\section{GERMAN GOVERNMENT AND POLITICS}

\section{Political and Constitutional History}

Political and constitutional history

The standard work for the historical development of Germany from the attempts at reform of the German Confederation up to the foundation of the new German Empire is still Sybel, Heinrich von: "Die Begründung des deutschen Reiches durch Wilhelm I," Berlin 1889-1894, in English translation, "The Founding of the German Empire by William I." Volumes I-V translated by Perrin, Dr. M. I., assisted by Bradford, G.; Vols. VI-VII by SchimmelpfennigWhite, H. New York 1890-1898. This monumental work is based chiefly upon Prussian state documents.

This work should be supplemented by Treitschke, T. G. von: "Deutsche Geschichte im neunzehnten Jahrhundert," 5 volumes, Leipzig 1906-1909, of which unfortunately there does not yet exist any translation. It deals with the history of Germany in the nineteenth century up to 1848 . Treitschke writes entirely from a Prusso-German point of view. His style is extremely fascina ting and with his point of view he has had a tremendous influence upon the German youth.

As a third German reference we wish to recommend a collection of three little books, good for those who cannot read the other two voluminous works: Schwemer, R.: "Restauration und Revolution"; "Die Reaktion und die neue Ära"; "Vom Bund zum Reich," Leipzig, 1905.

[ 278] 


\section{CRITICAL BIBLIOGRAPHY}

A book which we recommend highly to those foreign students who are far advanced in their studies in German history and politics is: Meinecke, F.: "Weltbürgertum und Nationalstaat. Studien zur Genesis des deutschen Nationalstaates." München, 1908.

Of books in English, we suggest the following: "The Cambridge Modern History." Edited by Ward, A. W., Prothero, G. W., and Leathes, Stanley. Volume XI (The Growth of Nationalities), New York, 1909. Malleson, G. B.: "The Refounding of the German Empire 1848-1871," which however contains too much war history. Andrews, Ch. M.: “The Historical Development of Modern Europe from the Congress of Vienna to the Present Time." 2 volumes, New York, r 8961898. Flathe, Th.: Restoration and Revolution," "The Reconstruction of Europe," Volumes XVIII and XIX of the collection "History of all Nations," Philadelphia and New York, I905. These two volumes are translations from the German, made under the supervision of Wright, J. H. Rose, J. H.: "The Political History of Germany in the Nineteenth Century," Manchester, I9I2. This short survey is a very sympathetic appreciation of the making of history by the Germans, written with the purpose of promoting a better mutual understanding between England and Germany, and as such it was heartily welcomed by the German press. Hazen, Ch. D.: "Europe since I8I5," London, I9I0. A short history from 


\section{GERMAN GOVERNMENT AND POLITICS}

I 815 to the present time, narrative, not critical. At the end is a valuable critical bibliography.

A book against which we must warn is Seignobos, Ch.: "A Political History of Europe since I814," New York, 1899, a translation from the French. It has even been translated into German. It contains very bad mistakes, and it is impossible that the author has really investigated his German sources, to which he refers. For example, on page 483 he says: "The princes were no longer his equals, but his (the King of Prussia's) subjects." "The federal government itself has been so constructed as to give the Emperor the same preponderating power in the Empire as he had in Prussia as King. No decision can be made in opposition to him." "The sovereignty belongs, not to the German people, but to the Emperor and the Federal Council." Page 488: "The Empire, created in the likeness of Prussia, is a strictly constitutional monarchy."

A model short biography and essay on the history and spirit of modern Germany, the extract of a thorough study of the subject-matter, is Smith, Munroe: "Bismarck and German Unity," New York, I910.

A valuable source of information upon the history and politics as made by Bismarck, is Blum, H.: "Fürst Bismarck und seine Zeit." Seven volumes, München, 1894-I899. It is throughout pro-Bismarck. Other works on this subject are:

[280] 
Kloeppel, P.: "Dreissig Jahre deutscher Verfassungsgeschichte," Erstes Band: "Die Gründung des Reiches, und die Jahre der Arbeit" (18671877), Leipzig, 1900, is an interesting study of the first period of modern Germany.

LAmprecht, K. G.: "Deutsche Geschichte. Zur jüngsten deutschen Vergangenheit," 2. Band, 2. Hälfte Innere Politik. Äussere Politik. Freiburg, 1904. This volume of the well known Leipzig historian is based on a broad and thorough study of modern Germany. It is greatly to be regretted that no translation of it exists in English.

Lichtenberger, H.: "Germany and its Evolution in Modern Times." Translated from the French by A. M. Ludovici, New York, 1913. An investigation of the spirit of Germany in its development. One of the very best books in its line, written from a highly sympathetic point of view, with a thorough understanding of the spirit and forces at work in the German nation.

JoRDAN, D. S.: "Alsace-Lorraine - A Study in Conquest." In "The Atlantic Monthly," Volume CXIII, May, pp. $688 \mathrm{ff}$. A critical study of the conditions of Alsace-Lorraine at the present time, by one of the leading American peace champions.

PerRis, H.: "Germany and the German Emperor," New York, I9I2. The writer attempts to give an interpretation of the Germanic life of to-day by the aid of the Germanic past. He makes a serious and, in general, successful at- 


\section{GERMAN GOVERNMENT AND POLITICS}

tempt to investigate the spirit of Germany. It is critical but not prejudiced, taking generally the view of the German Radicals.

Onken, H.: "Germany under William II," in "The Quarterly Review," New York, October, 1913. A very interesting outline of Germany's achievements during the last twenty-five years.

\section{Government and Politics}

Lowell, A. L.: "Government and Parties in Govern- Continental Europe," 2 volumes, Boston, 1896. ment and The best short systematic treatise. Unfortunately polltics not up to date.

OGG, F. A.: "The Governments of Europe," New York, 1912. Less critical. As a whole exact and good for less advanced students.

Barker, J. Ellis: "Modern Germany. Her Political and Economic Problems. Her Policy, Her Ambitions, and the Causes of Her Success and of Her Failure." Fourth edition. New York, 1912. This book is of the greatest importance. It is written with a thorough and intelligent understanding of German home-politics. Very critical. In the chapters on foreign politics the author, a German renegade (originally Eltzbacher), is inspired by blind hatred towards Germany. The reader may agree with the writer or not, the book is always interesting.

Veritas (Pseudonym): "The German Empire of Today," London, 1902. An appreciative [282] 


\section{CRITICAL BIBLIOGRAPHY}

study of some activities of Germany; not always up to date.

Whitman, S.: "Imperial Germany," New York, I897. A popular book; not particularly important.

Bülow, B. von: "Imperial Germany." Translated from the German by M. A. Lewing. New York, I9I4. An account of Germany's politics under the leadership of the fourth Chancellor, by himself. A highly valuable and interesting book.

Collier, P.: "Germany and the Germans from an American Point of View." London, I9I3. A number of essays, original, critical but in general pro-German. It is one of the best journalistic products concerning Germany, but must be read cautiously.

Schierbrand, Wolf von: "Germany. The Welding of a World Power." New York, I905. A journalistic book. In his endeavor to appear more American than old-stock Americans, the author often loses the objective view and forces himself sometimes to an extreme anti-German attitude. The facts are frequently incorrect.

Dawson, W. H.: "The Evolution of Modern Germany." London, 2d edition, 1909. A scholarly book by a very well informed specialist on German economic and political questions, showing a clear understanding of Germany's struggles and aims.

Holland, A. W.: "Germany to the Present Day - A Short History." London, I9I3. An 


\section{GERMAN GOVERNMENT AND POLITICS}

appreciative, brief, popular outline of modern Germany, with an historical introduction of Germany's past.

BERRY, R. M.: "Germany of the Germans." New York, 1910. Much read in the United States. A journalistic little volume written with the best intentions but without proper understanding of the German political spirit.

Tower, Ch.: "Germany of Today." New York, 1913. Journalistic, not always exact in details; popular; distinctly from the English view-point, but without prejudice against Germany.

Schröter, A.: “Der deutsche Staatsbürger," Leipzig, 1912. An account of the modern German political spirit and institutions from the German viewpoint.

A mass of authoritative information may be found in the: Handbuch der Politik, Herausgegeben von P. Laband, A. Wach, A. Wagner, G. Jellinck, K. Lamprecht, F. von Liszt, G. von Schanz, F. Berolzheimer. Berlin, I9I2-I3.

\section{Constitutional Law}

The Constitution of the present German Constl- Empire may be found in Howard, B. E.: “The tutlonal law German Empire"; Dodd, W. F.: "Modern Constitutions," Volume I; James, E. J.: "The Federal Constitution of Germany," 2d edition, in "Publications of the University of Pennsyl[ 284] 
vania. Series in Political Economy and Public Law." No. 7 .

The other Constitutions mentioned in the historical introduction are given in absolutely accurate copies from the original in the collection of constitutions edited by $\mathrm{K}$. Binding: In one volume, "Die Konföderations-Akte der Rheinischen Bundesstaaten" vom I2. Juli I 806; "Die deutsche Bundes-Akte" vom 8. Juni, I815; "Die Wiener Schluss-Akte" vom 15. Mai 1820 . Leipzig, 1905. In another volume, "Die Verfassung des Deutschen Reiches" vom 28. März 1849, und "Die Entwürfe der sogenannten Erfurter Unionsverfassung" (März und April, 1850). Leipzig, 1905. In a third little volume, "Die Verfassungen des Norddeutschen Bundes vom 17. April I867, und des Deutschen Reichs, vom I6. April I87ı." Leipzig, I907.

Extracts from the Deutsche Bundesakte in English are given in Robinson, J. H.: "Readings in European History,” Boston, 1906.

The most common collection of the important laws of the Empire is Triepel, H.: "Quellensammlung zum Deutschen Reichsstaatsrecht." Tübingen, 1907. Laws which are not contained there may be found in the Guttentagsche (Berlin) individual edition of laws.

The standard dictionary is Fleischmann, M.: "Wörterbuch des deutschen Staats- und Verwaltungsrechts," Ist edition 1890 , $2 \mathrm{~d}$ edition, Tübingen, IgI I-I9I4. 3 volumes. 


\section{GERMAN GOVERNMENT AND POLITICS}

The standard handbook is Hue de Grais: "Handbuch der Verfassung und Verwaltung in Preussen und dem Deutschen Reiche." Berlin, 1908.

The organization of the different Imperial offices and their officers are given in the "Handbuch für das Deutsche Reich," published yearly by the Reichsamt des Innern.

Burgess, J. W.: "Political Science and Comparative Constitutional Law." 2 volumes, Boston, 1893. A thorough and splendid book, which will always be a standard work. The study of it is indispensable for any advanced work in German government in American universities.

Howard, B. E.: "The German Empire," New York, 1906. Based on the study of constitutional law in German universities. Not original, but absolutely scientific.

Wilson, W.: “The State." Chapter VII. Revised Edition. Boston, I9II. A brief account of the government of Germany. Recommended for first information.

Gierke, O.: "German Constitutional Law in its Relation to the American Constitution." In "Harvard Law Review," Volume XXIII, Cambridge, Mass. A sketch of the German Constitution compared with that of the United States and England.

LABAND, P.: "Das Staatsrecht des Deutschen Reiches." 5 th edition in 4 volumes. Tübingen, I9I. The great standard work in German [286] 
constitutional law. It must be read by every advanced scholar of German government. The smaller, one-volume edition, 6. Auflage 1912, "Deutsches Reichsstaatsrecht," is mostly used by students, the larger edition by instructors.

Haenel, A.: "Deutsches Staatsrecht." Leipzig, 1892. A most profound book, historical and philosophical. Of use only to the most advanced students.

ARndT, A.: "Das Staatsrecht des deutschen Reiches." Berlin, 1901. Valuable especially on account of the constitutional history of every political institution.

Meyer, G.: "Lehrbuch des deutschen Staatsrechts." Leipzig, I 899. A clear and good textbook.

Zorn, Ph.: “Das Staatsrecht des Deutschen Reichs." I. Band. Das Verfassungsrecht. Berlin, 1895. II. Band. Das Verwaltungsrecht. Berlin, 1897. Two valuable volumes of a leading authority on constitutional law in Germany.

Two excellent little volumes are: Loening, E.: "Grundzüge der Verfassung des Deutschen Reichs." Leipzig, I90I ; and especially Zorn, Ph.: "Die deutsche Reichs-Verfassung." Leipzig, 1907 .

Good commentaries on the Constitution are Arndt, A.: "Verfassung des Deutschen Reichs. Mit Einleitung und Kommentar." Berlin, I9II.

ZoRn, Ph.: "Die Verfassungsurkunde des Deutschen Reichs." Berlin, I895. 


\section{GERMAN GOVERNMENT AND POLITICS}

SEydel, M. von: "Commentar zur Verfassungsurkunde für das Deutsche Reich." Freiburg i.B., 1897. Seydel's commentary is especially interesting since he applies consistently his theory of state sovereignty to the different articles of the Constitution.

$V^{\text {te }}$ Combes de Lestrade, "Les Monarchies de l'Empire allemand." Paris, 1904. A scholarly French treatise on German constitutional law.

The best treatise on the constitutional law of Alsace-Lorraine is Fischbach, O.: "Elsass-Lothringen." Tübingen, r9r4. Volume XXII of the collection: "Das öffentliche Recht der Gegenwart." An extensive bibliography may be found there.

Borgeaud, Chr.: "Adoption and Amendment of Constitutions," translated by E. D. Hazen and J. M. Vincent. New York, I895.

BORnHAK, C.: "Wandlungen der Reichsverfassung." An article in "Archiv für öffentliches Recht 26."

LABAND, P.: "Die geschichtliche Entwickelung der Reichsverfassung seit der Reichsgründung." In "Jahrbuch des öffentlichen Rechts der Gegenwart." Bd. I, 1907. Tübingen, 1907.

An account of the constitutional progress of the German Empire is given every year in the "Jahrbuch des öffentlichen Rechts der Gegenwart." Herausgegeben von Jellineck, Laband und Piloty. Tübingen, beginning 1907. 


\section{Theoretical Discussions of the Nature of the Empire}

BRIE, S.: "Bundesstaat. Eine historisch-dogmatische Untersuchung." Leipzig, 1874 .

LE FUR, L.: "État fédéral et confédération d'état." Paris, 1896.

Freeman, E. A.: "History of Federal Government, from the Foundation of the Achaian League to the Disruption of the United States, I863." Theoretical discussions about the nature of the Empire Republished with the addition of new chapters on Italy and Germany, I 893, under the title "History of the Federal Government in Greece and Italy."

SEYdel, M. von: "Vorträge aus dem allgemeinen Staatsrecht," in "Annalen des Deutschen Reichs" Volumes 3I-33.

Haenel, A.: "Studien zum Deutschen Staatsrecht," 2 volumes, Leipzig, I 873 and 1888 .

Hudson, R.: "The North German Confederation." In "Political Science Quarterly," Volume 6r.

Du Buy, J.: "Two Aspects of the German Constitution." New Haven, I894. A recommendable doctor's dissertation.

Shephard, W. J.: "Tendencies toward Ministerial Responsibility in Germany." In "The American Political Science Review," Volume V, No. 1. This article represents the wishes of the Liberals and Radicals in Germany as actual tendencies. It is very interesting since it gives 


\section{GERMAN GOVERNMENT AND POLITICS}

the opinion of the majority of scholars in the United States.

\section{Statistics}

The official statistics of the German Empire Statistics have been published by Puttkammer and Mühlbrecht, Berlin, as "Statistik des Deutschen Reichs," edited by the Kaiserliche Statistische Amt. For ordinary purposes the statistical yearbook, Statistisches Jahrbuch für das Deutsche Reich, giving in a condensed form all the more important data, is a sufficient source of information. A list of all the different volumes may be obtained from Puttkammer \& Mühlbrecht, Berlin, by asking for "Verzeichnis der Veröffentlichungen des Kaiserlichen Statistischen Amtes."

\section{The Kaiser}

Steinbach, R.: "Die rechtliche Stellung des

The Deutschen Kaisers verglichen mit der des Präsidenten der Vereinigten Staaten von Amerika." Leipzig, I903.

Burgess, J. W.: "The German Emperor," in "Political Science Quarterly," Volume III.

ZoRN, PH.: "The Constitutional Position of the German Emperor" in "Annals of the American Academy of Political Science," Volume I4.

Hudson, R.: "The German Emperor and the Federal Council," in "Political Science Quarterly," Volume X.

[290] 
The foregoing monographs, all of them good, are concerned with the legal position of the German Kaiser. The following literature deals with the personality and political position of the Kaisers:

Forbes, A.: "William of Germany." A short, popular biography of William I. New York, I 888 .

The correspondence of William I and Bismarck with other letters from and to Prince Bismarck. Translated by J. A. Ford. New York, 1903.

Poschinger, M. von: "Life of the Emperor Frederic." Edited from the German of M. von Poschinger, with an introduction by Sidney Whitman. New York, Igor. Translated and condensed from the German work "Kaiser Friedrich. In neuer quellenmässiger Darstellung von M. von Poschinger." 3 volumes. Berlin, I 8981900. In the controversies between Bismarck and Frederic III and his consort, the writer takes a decided anti-Bismarck point of view. There are few English people who do justice to Bismarck in this regard. Their sympathy goes naturally with the daughter of Queen Victoria, with English parliamentary liberalism against Prussian conservatism.

"Kaiser Friedrich III. Briefe, Reden und Erlasse." Herausgegeben von G. Schuster, I907. (Anonymous) "The German Emperor William II." London, 1896.

Frederic, H.: "The Young Emperor William II of Germany." New York, 1891. A book for 


\section{GERMAN GOVERNMENT AND POLITICS}

the general public, anti-Bismarck in regard to Bismarck's controversy with Empress Frederic.

Schierbrand, W. von: "The Kaiser's Speeches." New York, 1903. A selection of his earlier speeches.

Kaiserreden. Edited by J. J. Weber. Leipzig, 1902.

Burgess, J. W.: "The German Emperor and the German Government.” New York, I909. An address delivered before the Germanic Society of America. A defense of the views of the German Emperor.

Fried, A. H.: "The German Emperor and the Peace of the World." New York, 1912. A book which shows Kaiser Wilhelm II as Peace Lord. A strong book, for which the author received the Nobel Prize for the Promotion of Peace.

\section{Bismarck Literature}

The literature in regard to Bismarck, his per-

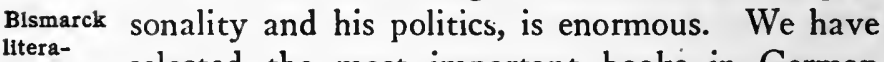
ture selected the most important books in German and several in English and French. Those who are interested in special topics will find a good guide in the selection of bibliography in the following:

Singer, A.: "Bismarck in der Literatur. Ein Bibliographischer Versuch.” Würzburg, 1909.

In the first place of Bismarck literature stands his great auto-biography: Bismarck, Fürst $\mathrm{O}$. von: "Gedanken und Erinnerungen." 2 volumes.

[292] 
Stuttgart, I898. It is naturally a highly subjective work and presupposes an intimate knowledge of German and European politics. It is the monumental work of German and European politics during the leadership of the greatest statesman of the second half of the nineteenth century. It is translated into English under the title:

"Bismarck: The Man and the Statesman. Being the Reflections and Reminiscences of Otto, Prince von Bismarck. Written and Dictated by himself after his Retirement from Office." Translated from the German under the Supervision of A. J. Butler. New York, 1899.

Other splendid biographies of Bismarck are:

LENZ, M.: "Geschichte Bismarcks." Leipzig, 1911.

Marcks, E.: "Bismarck. Eine Biographie." I. Band. Bismarcks Jugend. Berlin, 1910.

EngelhaAf, G.: "Bismarck. Sein Leben und Sein Werk.” Stuttgart, I9I I.

The following monographs of the Bismarck specialist $\mathrm{H}$. von Poschinger are all highly recommended as works of thorough investigation and study:

"Fürst Bismarck als Volkswirt." 5 volumes. Berlin, I889-I89I.

"Fürst Bismarck und die Diplomaten." I852I890. Hamburg 1900.

"Fürst Bismarck und der Bundesrat." 5 volumes. Stuttgart, I897-190I. 


\section{GERMAN GOVERNMENT AND POLITICS}

"Bismarck und die Parlamentarier." 3 volumes. Breslau, I894-I896.

In regard to the English literature we refer once more to Smith's, M., little biography: "Bismarck and German Unity." New York, 1910. Furthermore:

Lowe, CH.: "Prince Bismarck. An Historical Biography." 2 volumes. London, 1887.

Stearns, F. P.: "The Life of Prince Otto von Bismarck." London, 1899.

Good short character sketches and summaries of Bismarck's work are found in:

Whrte, A. D.: "Seven Great Statesmen." New York, 19ro.

Sloane, W. M.: "Bismarck as a Maker of Empire." In "Political Science Quarterly." Volume 15 .

An excellent French book is Matter, P.: "Bismarck et son temps." 3 volumes. Paris, 19051908.

The best and most complete collection of Bismarck's speeches is:

Конц, H.: “Die politischen Reden des Fürsten Bismarck. Historisch-kritische Gesammtausgabe." I4 volumes. Stuttgart, I892-1905.

A valuable little volume, which will prove very useful to the instructor, is:

Kuhlenbeck, L.: "Otto von Bismarck. Reden und Aussprüche zur deutschen Reichsverfassung." Berlin, I90I. 


\section{Chancellors and Secretaries of State}

As an introduction to this study may be read the well-known monograph:

Dupriez, LÉon: "Les Ministres dans les principaux pays de l'Europe et d'Amérique." Tome I. Cinquième partie. Paris, I892. In several Chancellors and Secretarles of State points now antiquated. Also Raynolds, E. V.: "Prussian Ministries and Imperial Rule," in "The Yale Review." Volume I, No. 2.

Shepard, W. J.: "Tendencies toward Ministerial Responsibility in Germany," in "The American Political Science Review." Volume V, No. I; with which article we absolutely disagree.

Documents relating to the chancellors after Bismarck are:

Caprivi, G. L. Graf von: "Die Reden des Grafen von Caprivi im deutschen Reichstage, preussischen Landtage und bei besonderen Anlässen." I 883-1893, mit der Biographie und dem Bildnis, herausgegeben von Rudolf Arndt. Berlin, I 894 .

Hohenlohe-Schillingsfürst, Ch. K. V., Memoirs of. Edited by F. Curtius. English Edition supervised by G. W. Chrystal. New York 1906. 2 volumes. These memoirs, certainly not published as the Prince himself would have desired, contain an indiscriminating mass of trivial and important material, mere gossip and highly valuable facts and opinions of the third Chancellor. 


\section{GERMAN GOVERNMENT AND POLITICS}

Consequently, it is not a first-class source and is to be used very cautiously.

"Graf Bülows Reden; nebst urkundlichen Beiträgen zu seiner Politik." 3 Bde. I903-I909. Herausgegeben von $\mathrm{O}$. Hötzsch.

\section{Legislative Department}

All the laws and ordinances of the Empire are Legis- officially published in the "Bundes-Gesetzblatt lative department des Norddeutschen Bundes," since 1867. Berlin. Since I87I, Reichs-Gesetzblatt, Berlin.

The debates of the Reicbstag since the existence of the parliament are printed by the government as "Stenographische Berichte des Deutschen Reichstags."

Organization, rules of procedure, biographies of members, statistics in regard to the present Reicbstag, may be found in Hillger, H. Kürschners "Deutscher Reichstag. Biographisch-Statistisches Handbuch. XII. Legislaturperiode." Berlin, 19I2. The five preceding legislative periods have been treated in similar volumes.

General discussions about the Reichstag and Bundesrat are found in:

Marriot, J. A. R.: "Second Chambers, an Inductive Study in Political Science." Oxford, 1910.

Moreau, F. et Delpech, J.: "Les Règlements des assemblées législatives." Paris, I906-I907. 2 volumes.

Research study of political parties in Germany [ 296] 
has not advanced far enough to have produced a standard work. The programs of the parties are found in a little volume:

Mahler, K.: "Die Programme der politischen Parteien in Deutschland." Zusammengestellt von Mahler, K. Leipzig, I9I I. A translation of these programs into English would be desirable.

The principles and history of each party are systematically reviewed by:

Grotewald, 'Chr.: "Die Parteien des deutschen Reichstags." Leipzig, I908.

A vivid picture of the spirit of the parties in the Reichstag are the essays of Friedrich Naumann: "Die politischen Parteien." Berlin, 1910.

The history of the great National-Liberal Party is found in the excellent biography by:

Onken, H.: "Rudolph von Benningsen: Ein deutscher liberaler Politiker. Nach seinen Briefen und hinterlassenen Papieren." 2 volumes. Stuttgart, 1910.

The standard work of the history of the SocialDemocratic Party is: -

Mehring, F.: "Geschichte der deutschen Socialdemokratie." 4 volumes. Stuttgart, 1906.

In the English language we have chapters on party history in Lowell's and Ogg's books.

A very brief outline on the subject is:

Gore, J. H.: "Political Parties and Party Policies in Germany." New York, 1903.

The Social-Democratic party is treated in the following: 


\section{GERMAN GOVERNMENT AND POLITICS}

Dawson, W. H.: "German Socialism and Ferdinand Lassalle." London, I891. 2d edition.

ELY, R. Th.: "French and German Socialism in Modern Times." 2 New York, I883.

Russell, B.: "German Social Democracy." New York, I896.

These treatises, however, do not embrace the important recent developments.

Every student should read K. Marx and F. Engels, "Das Kommunistische Manifest." London, 1848. Authorized English translation: "Manifesto of the Communistic Party," London, I 888.

The Bundesrat is investigated in Robinson, J. H.: "The German Bundesrath. A Study in Comparative Constitutional Law." In "Publications of the University of Pennsylvania." Series in Political Economy and Public Law. No. 18. Philadelphia, I906. A highly commendable, scientific, thorough monograph.

\section{Foreign Affairs and Military Power}

The following books are the leading year-books

Forelgn affairs and milltary power of Germany, England and France in regard to foreign affairs. All three take a decidedly national point of view:

Schiemann, Th.: "Deutschland und die Grosse Politik." Berlin since 1900 .

"Annual Register." A Review of Public Events at Home and Abroad. London. Beginning $175^{8}$. La Vie politique dans les deux mondes. Publiée [298] 
sous la direction de A. Viallate. Paris. Since 1906-1907.

Excellent historical accounts of diplomacy are:

Rose, J. H.: "The Development of the European Nations." 1870-1900. New York, 1905. Volume I, Chapter VI (The German Empire). Volume II, Chapter I (The Triple and Dual Alliances).

Onken, H.: “The German Empire." In "Cambridge Modern History," Volume XII (The Latest Age). Chapter VI. New York, 1910.

A source of the very greatest importance is naturally Bismarck's autobiography (see p. 293).

The French version of the 1875 affair is best represented in the book: "An Ambassador of the Vanquished." Viscount Élie de Gontant-Biron's Mission to Berlin, $1871-1877$, from his Diaries and Memoranda by the Duke de Broglie. Translated with notes, by Vandarn, Albert D. New York, 1896.

The fundamental documents of the formation of the Triple Alliance and its interpretation are to be found in the following works, besides in Bismarck's autobiography:

"The Memoirs of Francesco Crispi." Translated by Mary Prichard-Agnetti from the documents collected and edited by Th. Palamenghi-Crispi. 3 volumes. New York, 1912, 1914.

Wertheimer, E. von: "Graf Julius Andrassy. Sein Leben und seine Zeit." Nach Ungedruckten Quellen. 3 volumes. Stuttgart, 1914. 


\section{GERMAN GOVERNMENT AND POLITICS}

The French view of European diplomacy after 1870 is given by Hanotaux, G.: "La France Vivante." 4 volumes. Paris. Translated into English by Tarver, J. Ch.: and Sparvel-Bayley, E.: "Contemporary France." 4 volumes. New York, I903-r 909.

The Dual Alliance and its relation to the Triple Alliance is very ably treated from the French point of view by Tardieu, A.: "France and the Alliances. The Struggle for the Balance of Power." New York, 1908. Translated from the French. This is one of the very best books on modern diplomacy.

The origin and basis of the Dual Alliance is treated in a monograph by:

GORlOF, V. DE: “Origines et Bases de l'Alliance Franco-Russe." Paris, I9I3.

The diplomatic history of the Conference of Algeciras is given by Tardieu, A., in his monograph: "La Conférence d'Algéciras. Histoire Diplomatique de la Crise Marocaine." (I5 Janvier7 Avril, 1906.) Paris, 1908. And by: Morel, E. D.: "Morocco in Diplomacy." London, I912.

The first of these books takes the side of the Triple Entente and the other book that of Germany.

The imperialistic policy of modern Germany is ably explained and defended by the statesman who helped to inaugurate it as Secretary of Foreign Affairs and who later carried it on as its leader, the former Chancellor of the German Empire, Prince Bernhard von Bülow, in his book " $\mathrm{Im}$ [300] 


\section{CRITICAL BIBLIOGRAPHY}

perial Germany." Translated by M. A. Lewenz. New York, 1914. It is an important source for the understanding of Germany's world policy under Kaiser Wilhelm II.

Reinsch, P. S.: "World Politics at the End of the Nineteenth Century as Influenced by the Oriental Situation," New York, 1900, shows a careful study and full understanding of the spirit and character of Germany's imperialism seldom found in the United States.

There are two English books dealing with Pan-Germanism. The one is written by an anonymous writer:

"The Pan-Germanic Doctrine. Being a Study of German Political Aims and Aspirations." London, 1904. This book is an excellent analysis of Pan-Germanism, and deserves to be better known. The author shows a full mastery of the difficult question. He says: "Officially the German government has nothing to do with it. The two things must be kept separate. PanGermanism as expounded by the League, and German forward policy are not one and the same thing; for this reason German politics will be avoided. The German government will not be described as benevolently Pan-German."

In recommending this exposition of Pan-Germanism we must warn against:

Usher, R. G.: "Pan-Germanism." Boston, 1913. This unfortunately widely known, sensational book is a fantastic creation, a product 


\section{GERMAN GOVERNMENT AND POLITICS}

of Germanophobia. "A mass of dogmatism and prognostication" ("The Nation," May 22, 1913). Says the Athenæum, the English magazine (April 26, 1913): "We feel sure that Dr. Usher wishes well to England, but it is sometimes necessary to pray to be saved from one's friends, and a book such as this, which will attract attention abroad, cannot improve, and may possibly embitter our relations with Germany."

An excellent volume, welcomed heartily in Germany, is:

Hurd, A. and Castle, A.: "German Sea Power. Its Rise, Progress and Economic Basis." London, 1913. Although patriotic Englishmen, who believe in England's absolute supremacy of the sea, they are far from chauvinism; on the contrary, their aim is to promote good relations between the two nations by destroying misunderstandings in regard to Germany's and England's actual naval policy.

The semi-official year-book for Germany's naval interests is:

Nauticus, "Jahrbuch für Deutschlands Seeinteressen." Edited since 1900. Contains also a brief account of Germany's foreign policy.

\section{Colonies}

A bibliography of the German publications on Colonies colonies is published annually by:

Brose, M.: "Die Deutsche Kolonialliteratur."

[302] 


\section{CRITICAL BIBLIOGRAPHY}

The official year-book published by the Colonial Office in Berlin is the "Koloniales Jahrbuch."

Other official publications of the Foreign Office (since 1908 the Colonial Office) are:

"Denkschrift über die deutschen Schutzgebiete"; since I908 under the title "Die deutschen Schutzgebiete in Afrika und der Südsee"; published annually.

The "Weissbuch." Official Correspondence relating to German possessions in Africa and the Pacific, and to the Congo, Egypt and East Asia. 20 volumes. Berlin, 1884-1900.

The official organ for the protectorates in which all laws and ordinances are published is the "Deutsches Kolonialblatt," published since I890.

Kiao-chau has its own official gazette, the "Verordnungsblatt für das Kiautchaugebiet," published by the Secretariat of the Navy since 1903 .

An annual review of the German colonial legislation is:

"Die deutsche Kolonial-Gesetzgebung," herausgegeben von Riebow, Zimmermann etc. Berlin since 1893 .

Short English treatises on German colonies are:

Keller, A. G.: "The Beginnings of German Colonization." Yale Review X.

Keltie, J. S.: "The Partition of Africa." 2d edition, London, I895.

Johnston, H. H.: "The Colonization of Africa." Cambridge, 1899. 


\section{GERMAN GOVERNMENT AND POLITICS}

Johnston, H. H.: "A History of the Colonization of Africa by Alien Races." Cambridge, I9I3.

Among the mass of good literature in German we have selected:

Zimmermann, A.: "Geschichte der Deutschen Kolonialpolitik." Berlin, I913.

Meyer, H. (and others): "Das deutsche Kolonialreich. Eine Länderkunde der deutschen Schutzgebiete." 2 volumes. I909-I9II. Two small but excellent books are:

SchneE, H.: “Unsere Kolonieen." Leipzig, 1908.

Heilborn, A.: "Die deutschen Kolonieen." Leipzig, I9I2.

\section{Commerce, Industry, Social Welfare}

Dawson, W. H.: "Social Insurance in Gercom- many." I883-I9II. London, I9I2. A serious industry, soclal welfare treatise on the history, operation and results of state insurance in Germany. Valuable, as all of Dawson's books.

Dawson, W. H.: “Bismarck and State Socialism." London, I89I. A short account of social legislation in Germany, based upon a good knowledge of the German sources and on personal investigation of conditions in Germany.

Howard, E. D.: "The Cause and Extent of the Recent Industrial Progress in Germany." Boston, 1907.

Ashley, A.: "The Social Policy of Bismarck." With a preface by Schmoller, Gustav von. Lon[304] 


\section{CRITICAL BIBLIOGRAPHY}

don, 1912. An excellent critical study with a comparison of German and English insurance legislation.

Roberts, E.: "Monarchial Socialism in Germany." New York, I9r3.

Helfferich, K.: “Germany's Economic Progress and National Wealth I888-1913." New York. Germanistic Society of America, I9I4. A little, highly interesting study which has justly attracted attention.

Wells, B. W.: "Compulsory Insurance in Germany." In "Political Science Quarterly." Volume 6.

Huebner, S.: "Relation of the Government in Germany to the Promotion of Commerce." In "Annals of the American Academy of Political and Social Science." Volume XXIV.

Highly valuable material may be found in the Investigations of the National Monetary Commission of the United States. Printed by the Washington Government Printing Office, I9Io. T. 8: German Imperial Banking Laws. Edited by Koch, Dr. R. Together with the German Stock Exchange Regulations:

German Bank Inquiry of 1908-1909, Stenographic Reports. 2 volumes.

The Reichsbank 1876-1900. Published under the auspices of the Reichsbank. English translation made for the Commission by Dr. F. C. Lieder.

Schumacher, H. A.: "Concentration of Ger- 


\section{GERMAN GOVERNMENT AND POLITICS}

man Banking." In "Political Science Quarterly," Volume 22.

"Festschrift über die Tätigkeit des Vereins Deutscher Eisenbahn-Verwaltungen in den ersten 50 Jahren seines Bestehens.” I846-I896. Berlin, 1896.

\section{The Judicial Department}

Any student who wants to do special work in

The judicial department

his field will find an excellent critical introduction and bibliography in Borchard, E. M.: "Guide to Law of Germany." Washington, I9I2. Library of Congress. It is highly desirable that such guides written by competent specialists should exist for all fields.

BORCHARD, E. M.: "Jurisprudence in Germany." In "Columbia Law Review," April, I9ı2.

Vierhaus, F.: "Die Entstehungsgeschichte des Entwurfes eines Bürgerlichen Gesetzbuches für das Deutsche Reich." Berlin, I888.

Higgins, A. P.: "The Making of the German Civil Code." In "Journal of the Society of Comparative Legislation." New Series, No. XIII.

The best English translation of the German Civil Code - a very difficult work - is that of a Chinese: Chung Hui Wang: "The German Civil Code." Translated and annotated with a historical introduction and appendix. London, 1907.

A competent criticism may be found in the "Journal of the Society of Comparative Legislation." New Series, Volume VIII. Written by [306] 


\section{CRITICAL BIBLIOGRAPHY}

E. J. Schuster, the well-known German-English specialist in German law. He has also written an excellent treatise on the Civil Code.

Schuster, E. J.: "The Principles of the German Civil Law." Oxford, I907.

The Commercial Code is translated by Platt, B. A.: "The German Commercial Code." London, 1900.

Good articles on other parts of the judicial department of Germany are:

Neitzel, W. "Non-Contentious Jurisdiction in Germany." In "Harvard Law Review." Volume XXI.

Hirschfeld, J.: "German Courts at Work" in "The Journal of the Society of Comparative Legislation." New Series, No. XXV.

Garner, J. W.: "The German Judiciary," in "Political Science Quarterly," Volume I7 and Volume I8.

Weinstock, H.: "The German Courts for the Arbitration of Industrial Disputes." In "Annals of the American Academy of Political and Social Science," Volume 36.

The much discussed problem of Administrative Law is best represented on the one hand by Dicey, A. V.: "Introduction to the Study of the Law of the Constitution." Chapter on "Droit Administratif." 7th edition, 1908 .

An able criticism of this book is: Parker, E. M.: "State and Official Liability" in "Harvard Law Review," March, 1906. 


\section{GERMAN GOVERNMENT AND POLITICS}

The other side is best given by:

Goodnow, F. J.: "Comparative Administrative Law," Volume II, pp. 216-239. New York, I893.

\section{Miscellaneous}

The fundamental question of physical influence Miscel- on the political character of the people and their laneous institutions is discussed in:

Ratzel, F.: "Anthropogeographie oder Grundzüge der Anwendung der Erdkunde auf die Geschichte." Stuttgart, 1882.

Ratzel, F.: "Deutschland. Einführung in die Heimatkunde." Leipzig, I898. A small, beautiful volume of the great German scholar of geography, in which he speaks of the influence of the geographical environment on the German people.

Schöne, E.: "Politische Geographie." Leipzig, I9II. A small volume based upon Ratzel's great work.

Partsch, J. F. M.: “Central Europe.” New York, 1903. Translated from the German by C. Black.

LYDE, L. W.: "The Continent of Europe." London, 1913. Chapter 20 (Germany). An an thropo-geographical outline of Germany.

Whitman, S.: “German Memories." New York, 1912. Personal memories of a foreigner who has lived in Germany for a long time as a journalist and has come into contact with many

[ 308 ] 


\section{CRITICAL BIBLIOGRAPHY}

leading Germans. He takes a very sympathetic standpoint towards the Germans.

WILE, F. W.: "Men around the Kaiser. Makers of Modern Germany." Philadelphia, I9I3. Short biographies and character-sketches of leading German men in all fields of activity in Modern Germany. Good for general information.

White, A. D.: "Autobiography of Andrew Dickson White." New York, I905. 2d volume. One of the most sympathetic modern autobiographies, full of good information and observation, by a cultured American scholar and diplomat of the very highest type. 

OUTLINE OF THE GOVERNMENT OF THE STATES OF THE GERMAN EMPIRE 


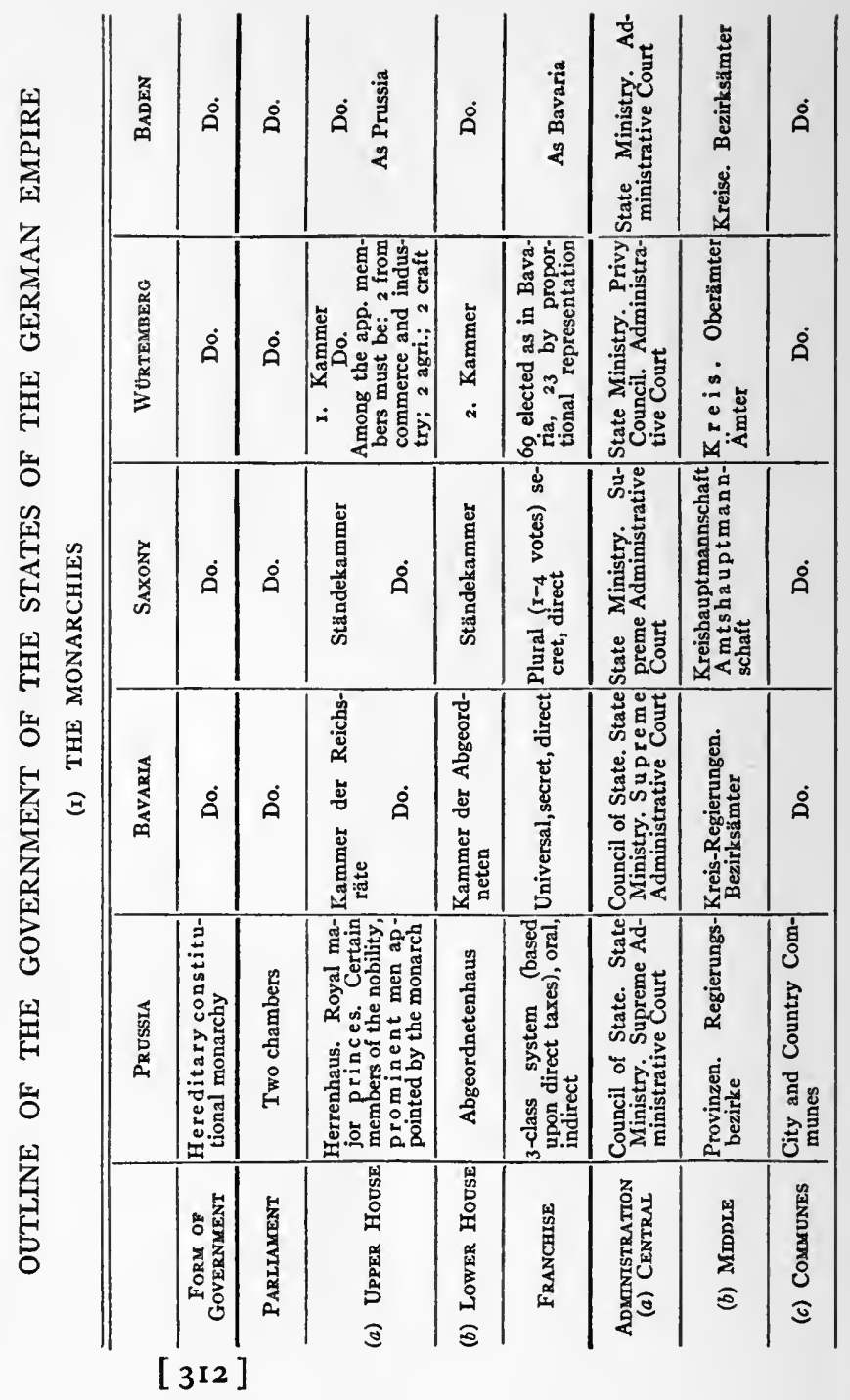




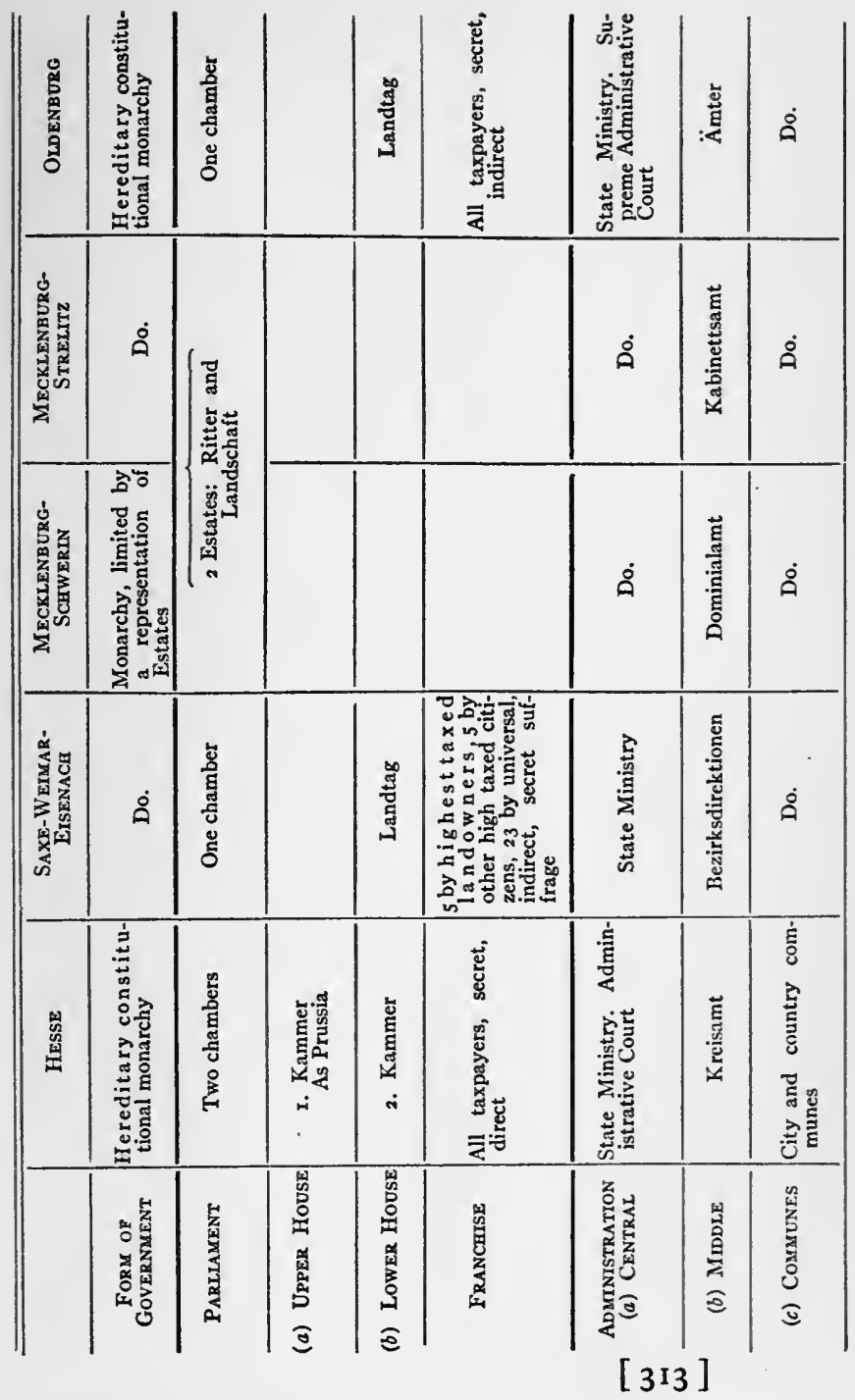




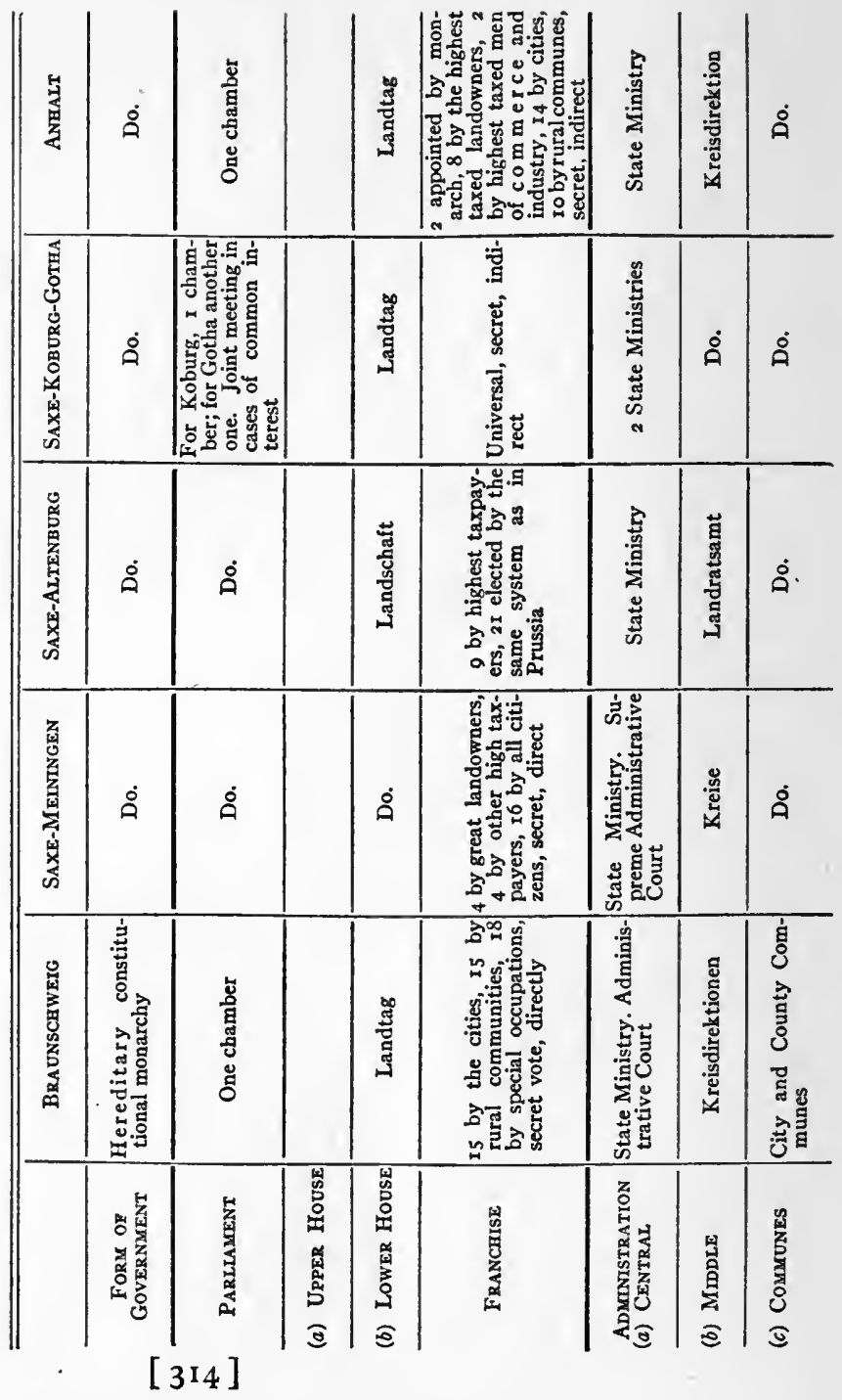




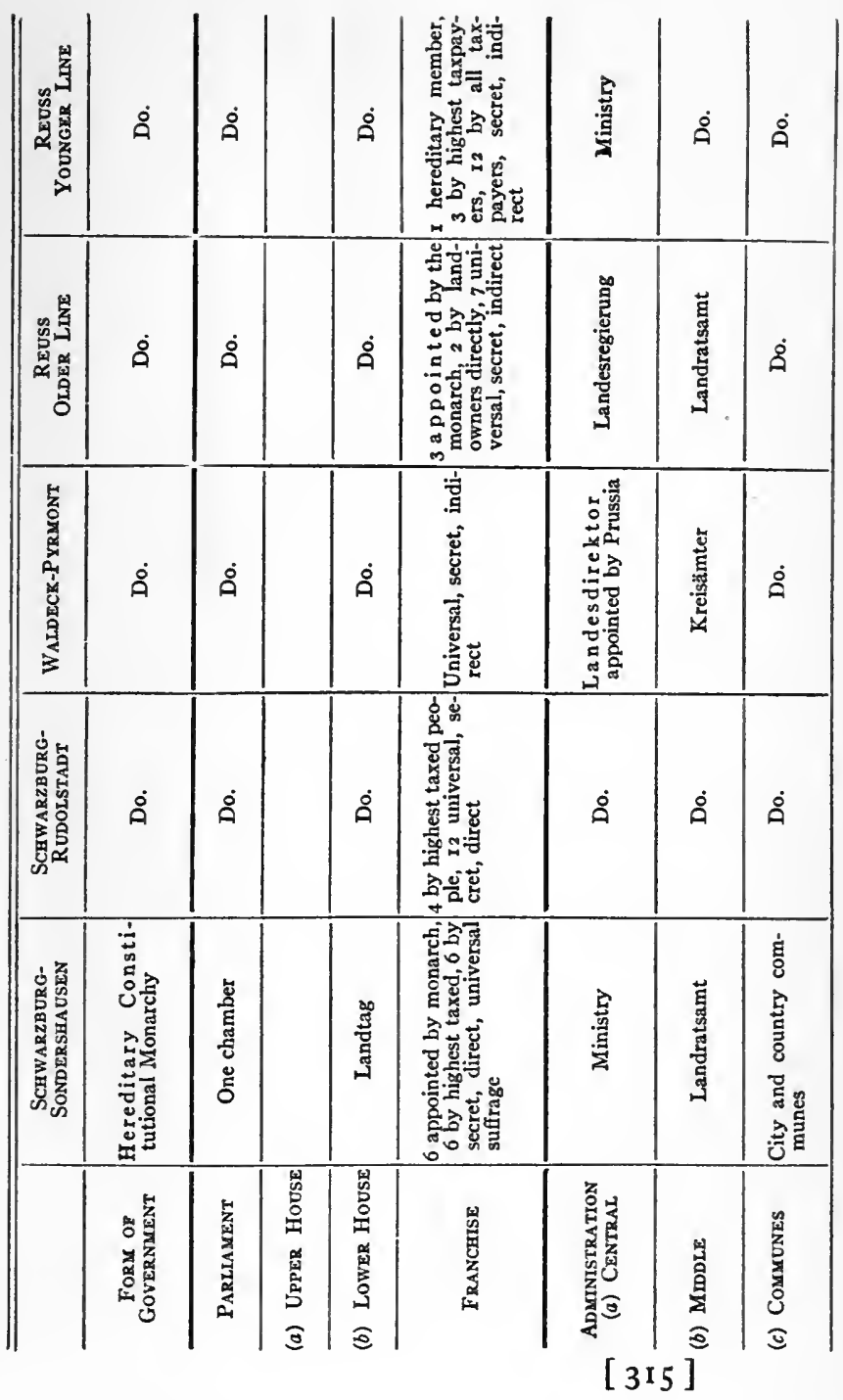




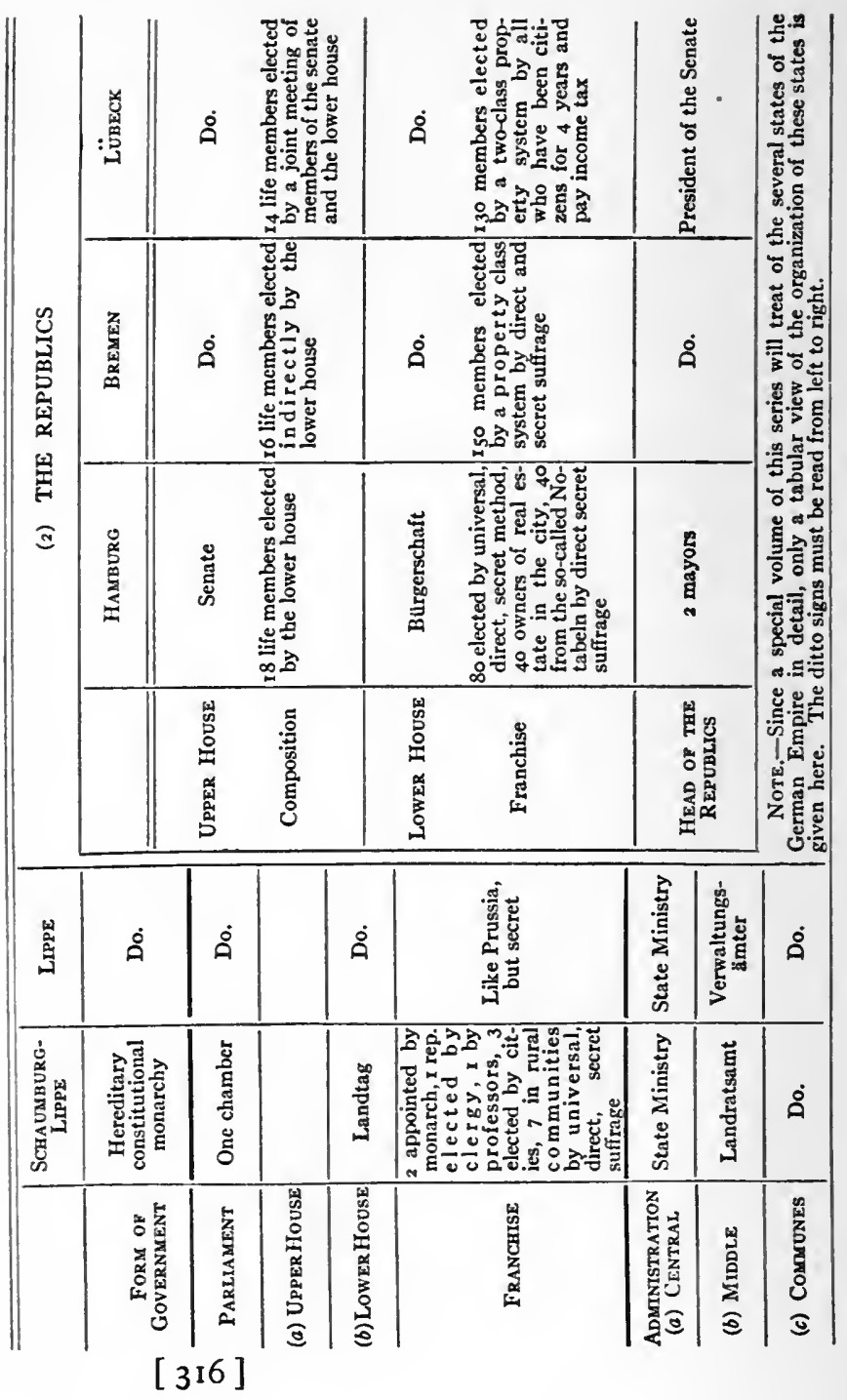




\section{INDEX}

In this index no reference has been made to titles of books or names of authors mentioned in the Select Bibliographies at the end of each chapter or the Critical Bibliography at the end of the book. But names and authors quoted or referred to in text and footnotes have been indexed.]

Abdul Aziz, Sultan, 247

Abteilungen, of Reicbstag, 52, 54,55

Administration of German Empire, civil service, II7, II8; pensions, II9; weights and measures, II9, 120; currency and banking, 120-122; protection of patents, 122, 123; supervision of trade and industry, I23-127; state insurance, 127-132; regulation of medical practice, 132; medical and veterinary police, 132, 133; increased expenses of, 134, 135

Administrative Authority, 30, 117

Administrative courts, 8, I I I, 198-204

Administrative law, 198-202

Administrative property, 140 Afghanistan, 263

Africa, early colonial experiences in, 165
Agadir, 252

Agrarian Union, formation of, 205, 206, 210

Agrarians, opposition of, to Caprivi, I03; to development of canals, 170; influence of, 205, 206, 210 , 228; party growth of, 234 Agricultural interests, supported by Conservatives, 205, 206, 210

Agriculture, regulation of, 4 I Albania, 255

Albert, Prince Consort of Great Britain, 83, 84 Alexander II, Czar, 237, 238 Algeciras, Conference of, 248250, 252

Aliens, naturalization of, 6,7 Allgemeine Landrecbt, $\mathrm{I}_{3}$ Alsace-Lorraine, area of, 3; religious denominations in, 4; representatives of, admitted to Bundesrat, 27; becomes part of German Empire, 27; special privileges of, 42; representa[317] 


\section{INDEX}

tives of, in Reicbstag, 48; votes of, in Bundesrat given to Prussia, 64, 65; Bundesrat committee on, 67; governmental authority of Kaiser over, 77; Hohenlohe governor of, r04; separate Fiskus of, r40; railroads of, 140, I68; army of, I50; history of, 176; Germanic character of inhabitants of, 176, 177; annexation of, to Germany, I77; development of, under the German Empire, 177-179; present status of, 180-182; desire of France for revanche for loss of, 236, 238, 254

Alsatians, in Reichstag, 144, 214, 234

Amendments, to German Constitution, 24, 25

Amtsanwalt, 197

Amtsgericbt, 192, 197

Amtsticbter, 192

Anhalt, representation of, in Reichstag, 48, in Bundesrat, 64

Annual Register, 105, 106 Anti-Semitic Party, 234 Anti-Semitism, 208, 210 Anti-socialist legislation, 222224, 227

Appeal, Courts of, 192

Army, necessity of strong, 2, 3, 157-159, 235; service in, duty of citizenship, 8 ; [3 18 ] increase in size of, $3 \mathrm{r}$; finances of, 32; Kaiser Commander in Chief of, 77, 150; reorganization of Prussian, by William I, 80,81 ; reformation of, by Caprivi, I03; supremacy of Prussia regarding, II4; increased expenses of, I34; additional taxes caused by increase of, 149 153; military service in, 153-156; the Septennate, 226, 227, 235; foreign policy based on strength of, 235

Arndt, A., cited, $25 n, 33,77 n$ Aufsicbtsamt für Privatversicberungen, 204

August Treaty, the, 19, 36

Ausfübrungsgesetze, 188

Ausscbiisse, 66

Austria-Hungary, 2, 13, 14; rivalry with Prussia, 15 ; excluded from Constitution of German Empire, 16; left out of Deutscbe Zollverein, I7; war with Prussia, I8, I9; Bismarck's leniency toward, 99; commercial treaty with, I03, I37; Bismarck's cultivation of, 235; treaty between Russia and, 236; objection of, to terms of Peace of San Stefano, 237; alliance of 1879 with Germany, 238; 


\section{INDEX}

formation of Triple Alliance, 239; alliance with Germany and Russia, 239; strained relations with Russia, 241; aids Germany in Morocco crisis, 249; annexation of BosniaHerzegovina by, 250; the Great War, 256

Austrian Code, 183

BADEN, area of, 3; joins North German Federation, 22; special privileges of, 42, I21, 130 $n$; reserved privileges of, 43; representation in Reicbstag, 48, in Bundesrat, 64; Civil Code in, 183

Bagdad railway, 251, 252

Balkan League, 255

Balkans, attempts of Russia to dominate, $236,237,255$, 256; claims of Austria on, 236, 237; peace restored in, by Germany and England, 254

Baltic provinces, 242

Bank, Imperial, 42

Banking, regulation of, II 122

Bankruptcy Law, 19I

Barker, J. E., quoted, $94 n$, 156, 172; cited, $173 n$, $23 \mathrm{I} n$

Bavaria, area of, 3 ; democratic tendency of, 3,4 ; joins North German Federation, 22; contingent of, in German Army, 31, 150, 151; criminal military law of, 32 ; special privileges of $42,43,65,118-121,130 n$, 151, 173, 174, $203 n$; representation of, in Reichstag, 48, in Bundesrat, 6466; limitations of, on military power, 77; union of, with Prussia advocated by Hohenlohe, 104; military budget of, 145; Civil Code in, 183; Oberstes Landesgericht in, 193

Bavarian Farmers Union, in Reicbstag, 234

Bebel, 46, $222 n$

Belgium, 2, 137, 256

Bennigsen, 216, 221 , 225, 226

Berlin, Congress of, 99, 237 Bernhard, Prof. L., quoted, I27, 128

Besoldungsgesetz, II 7

Bethmann-Hollweg, 106, 253 B. G. B. (Bürgerliches Gesetzbuch), see German Civil Code

Bismarck, Herbert, 265

Bismarck, Prince, policy of, before Austrian war, 17, 18; "blood and iron" doctrine of, 18; Constitution of North German Federation dictated by, 19; attitude of toward changes 


\section{INDEX}

in Constitution, 24, toward universal suffrage, 46, toward representation of all interests in Reicbstag, 58; friendship of William I for, 81 i 83 ; made Minister of William I, 82; genius and power of, 83 ; opposition of Frederick III to policies of, 84,85 ; rupture with William II, 95, 96; personality and importance of, as Chancellor, 98-102; resignation of Prussian premiership by, $108 n$; attitude toward Matrikularbeiträge, 138; protective tariff introduced by, 141; Imperial monopolies planned by, 14I, 142; reluctance of, to annex Alsace-Lorraine, I77, 235; struggle with Catholic Church, 217-219; breach with National Liberal Party, 219-22I; dislike for English form of Government, 220; anti-socialistic attitude of, 221-224, 226; attitude toward tariff, $1 \infty$, 224, 225; diplomacy of, 235-240; policy for isolation of France, 235, 238; cultivation of Austria and Russia, 235; leadership of Congress of Berlin, 237; formation of alliances with, [ 320]
Italy, Austria, and Russia, 238, 239; diplomatic domination of Europe accomplished by, 239, 240; Colonial policy of, 26I, 263267; quoted, 18, 20, 21, $24 n, 39,40,47,48,95,98$, $100,101 n, 108,109 n, 138$, $224 n, 236,252,266,267$

Blücher, 79

Blue-Black Bloc, 39, 229, 230, 232

Blum, H., cited, 24I $n$

Bodin, cited, 36

Boer war, 93, 94, 245

Bonaparte, Napoleon, see Napoleon

Bonn, University of, 83,88 Borchard, E. M., quoted on I87, 188

Bosnia, 237

Bosnia-Herzegovina, 250

Braunschweig, representation of, in Reicbstag, 48, in Bundesrat, 64

Bremen, special privileges of, 42; reserved privileges of, 43,44 ; representation of, in Reicbstag, 48, in Bundesrat, 64; naval docks at, 162

Brunswick, 64

Bucher, Lothar, 19

Budget, controlled by Reicbstag, 28, 145, 146; military, 32 , I45; constitutional provision for, 144, 145; workings of, 145, 146 


\section{INDEX}

Bülow, Prince, resignation of, 39, 93, 94, 106; chancellorship of, 104-106, 230, 232; quoted, $40 \mathrm{n}, 243$, 249, 250, 25 I $n, 254$

Bulgaria, 255

Bund der Landwirte, 205, 206 Bundesacte, $14 n$

Bundesrat, of German Empire, power of, to defeat constitutional amend ments, 24, to decide constitutionality, 25; representation of Alsace-Lorraine in, 27; increased importance of, 28 ; members of, 38 ; legislative powers of, 45; members of, admitted to Reichstag, 55, 68; composition of, 64; organization of, $65-67$; position of members of, 67,68 ; functions of, 68-70; judicial powers of, 70; character and principles of, 72 , 73; personnel of, 73; lawmaking process, I 10-1 16; coinage regulated by, I20; financial reforms proposed by, 142, 143; budget fixed by, 145, 146; control over finances by, 146; control of railroad rates by, I68

Bundesrat, of the North German Federation, 22, 74 Bundestag, organ of the Deutsche Bund, 14; functions of, 14, 15; reëstablished, I7; corresponds to Bundesrat, 64

Bundesversammlung, see Bundestag

"Bureau," of the Reichstag, II3

Canals, importance and development of, 170-173

Cape-Cairo telegraph line, German concessions to, 245

Capital punishment, I90 Caprivi, made Chancellor, I02; character and administration of, 103, 228, 229; resignation of Prussian premiership by, $108 n$; second head of navy, I60; commercial treaties made by, 103, 137, 228; destruction of Bismarck's diplomatic structure by, 240

Caroline Islands, sold by Spain to Germany, 265

Cartel Reicbstag, 227, 228

Catholic Church, struggle of Empire with, 217-219 Catholics, proportion of, in Germany, 4, in Reicbstag, 62, in Center, 206, 210 , in colonies, 274; control of Clerical Party by, 210. See also Clerical Party

Center, the, in Reicbstag, 53, 60,214 ; attitude of, toward Alsace-Lorraine, r81; com-

[32I] 


\section{INDEX}

position of, 206, 2 10, 211 . See also Clerical Party

Chancellor, Imperial, appointed by Kaiser, 29, 76; must be Prussian Prime Minister, 30, 97, 108; responsibility for military budget, 32, for Kaiser's acts, 78, 79, 97; chairman of Bundesrat, 65, 97; constitutional position of, 97, 98; Bismarck, 98-102; Caprivi, 102, 103; Hohenlohe, I03, I04; Bülow, 104-106; von BethmannHollweg, 106; head of Reicbsbank, 122

China, 135, 244, 245

Citizenship, German, means of acquiring, 5-7; loss of, 7,8 ; duties pertaining to, 8 ; suffrage conferred by, 50 Civil Service, 5, I17, I18, I54

Civil Service Law, Imperial, see Reicbsbeamtengesetz

Clausula Frankenstein, 26, 139, 142

Clerical Party, 39; representation of, in Reichstag, 49, 54, 6r, 72; seating of, in Reichstag, 53; Bismarck's struggle with, 99, ıo; Bülow's struggle with, 106; principles of, 207, 210, 21I; struggle with government over Papal [322] authority, 217-219; history of, 217-234

Code Napoléon, 183

Collier, Price, quoted, 96

Colmar, 179

Commerce, foreign, I64, 165

Commercial treaties, with foreign countries, I03, 137

"Communist Manifesto," 222

"Confederate Execution," I5

Conservative Party, 39, 47; representation of, in Reicbstag, 49, 53, 54, 62, 72; seating of, in Reichstag, 53; opposition of Bülow to, 106; attitude toward Alsace-Lorraine, I8I, I82; composition and principles of, 205-210; history of, 215-234

Constantinople, visit of William II to, 252

Constitution of German Empire, citizenship under, 5; lacks "bill of rights," 7; adopted by St. Paul's Parliament, 16; adoption of present, 22, 23; changes in, by amendment, 24-27; legislative powers of Reichstag and Bundesrat under, 45; pri ileges of Reichstag members under, 57; organization of Bundesrat under, 65-72; power conferred on Kaiser by, 76, 77; 


\section{INDEX}

position of Chancellor under, 97, 98; law-making process under, I 10-116; internal administration under, I17; regulation of medical practice under, 132, 133; army organization based on, 150, 151; government ownership of railroads under, 167, I68; Imperial posts, telegraphs, and telephones under, 173, 174; administrative law based on, 202. See also Reicbsverfassung

Constitution, of the North German Federation, 21, 74 Constitution, of Prussia, 7 Consular officers, $8,134 n$, 258

Coolidge, A. C., cited, $246 n$ Courts, creation of, $30,3 \mathrm{I}$; inability of, to pass upon constitutionality of laws, 115, I16; disciplinary, 118; organization of, 19I-194. See also Administrative Courts

Credit, of states, 4 I

Crimen laesae majestatis, see Lise-Majesté

Criminal Law, I88-I91

Criminal Law Code, quoted, $8 n, 5 \mathrm{I}, 52$

Criminals, 7,8

Crown Prince, see Frederick William
Currency, regulation of, I19122

Customs Duties, 136, 137

"Daily Telegraph," the, interview of William II with, 92, 93, 250

Damascus, visit of William II to, 252

Danes, in population of Germany, 4; in Reichstag, 214

Danish Law, of Christian V, in Schleswig-Holstein, 183

Danzig, I6I

Delcassé, 247, 248

Denmark, 2, 84

Dernburg, 267, 268

Deutsche Bund, 14-16

Deutscbe Kolonialgesellscbaft, 26r

Deutsche Zolloerein, 17

Deutscber Kaiser, see Kaiser Deutscber Kolonialoerein, 26I Deutscbes Reich, see German Empire

Dicey, cited, 20r

Diplomatic officers, 8, 257, $25^{8}$

Disciplinary Courts, see Courts

Dispositionsfond, 78

Dissidents, in Reicbstag, 62

Disziplinarbof, 118, I 19

Disziplinarkammern, 118

Divorcées, citizenship of foreign, in Germany, 5 


\section{INDEX}

Döllinger, Prof., opposition of, to Papal Infallibility, 218

Dreibund, see Triple Alliance Dreikönigsbund, 16

Dual Alliance, formation of, by France and Russia, 241-243; German domination of Europe overthrown by, 242, 243

Du Buy, Dr., cited, 37

Economic Union, composition and principles of, 206, 207, 209

Egypt, 264

Eichungsämter, 119

Elections, to Reichstag, 50-53

Elector, the Great, 157, 170, $260 n$

Emigration, from Germany, 261, 262

Engels, 222

Engere Rat, I4

England, see Great Britain

Erbrecht, 188

Erfurt, Parliament of, I9

Espionage Law, 191

Excise taxes, 137

Exemptionsprioilegien, 42-44

Exports, increase of, 164

Extradition, 8

Familienrecbt, 188

Farmers' Union, 103

"Federal execution," 77

Feldzugmeisterei, 149

[324]
Ferrier Ministry, in France, 265

Finances, state and Imperial, 26, 31; of army, 32; state, 41 ; increased expenses of Empire, 134, 135; sources of income, 135-140; debts of Empire, 140-142; unsatisfactory condition of Imperial, 142, 143; budget, 144-146; control over Imperial, 146, 147; collection of Imperial revenues, 148 Fiskus, 32, 140

Forbes, cited, 80

Foreign affairs, administered by Empire, 41, 256-258; Bundesrat committee on, 66 ; in hands of Kaiser, 76 , 256-258

Foreign Office, organization of, 256, 257; Diplomatic service, 257; Consular service, 258

Foreign policy, 235-256

Fortscbrittliche Volkspartei, 225

Fortscbrittspartei, $216 n$

France, 2; protectorate over Rheinbund, 13; Germany's first war with, 21, 46; ambition of, for colonial empire, 88; William II arouses hostility of, 93; Bismarck's preparation for war with, 99; Germany's policy for isolation of, 235, 238; dip- 


\section{INDEX}

lomatic crisis of 1875 with Germany, 235, 236; desire for reoanche, 236, 238, 254; Dual Alliance formed with Russia, 24r-243; opposition to Japan, 244; rapprocbement with England, 246-248; Morocco affair, 247-249, 25 I-254; strained relations with Germany, 256; the Great War, 256 Franchise, of the Reichstag, 46,50

Franco-German War, 84, 140, 141, 178

Frankfort Assembly of Princes, 19

Frankfort-on-the-Main, I4, 15, 17; annexed by Prussia, 19; vote of, in Bundestat given to Prussia, 64

Franz Ferdinand, Archduke, assassination of, 256

Frederick II, of Prussia (the Great), $82,83,158,170$

Frederick III, as Crown Prince, quoted, $40 n$; succeeds William I, 83; early life, 83; marries Princess Victoria of England, 84; dissatisfaction with Ministry of Manteuffel, 84; opposition to policies of Bismarck, 84-86; takes part in war with Denmark, 84; military ability of, 84 , 85 ; interest in social re- form, 85; becomes Regent, 85 ; illness and death, 85 , 86 ; liberalism of, 86 ; succeeded by William II, 87

Frederick William, of Brandenburg, see Elector, the Great

Frederick William I, 158

Frederick William III, of Prussia, 79

Frederick William IV, of Prussia, I6, I9

Frederick William, Crown Prince, quoted, 12

Free Catholics, proportion of, in Reichstag, 62

Free Conservative Party, representation of, in Reichstag, 53; composition and principles of, 206, 207, 209; history of, 216-234

Free Thinkers, proportion of, in Reicbstag, 62

Free Thinking People's Party, 225

Free Thinking Union, 225 Free Trade, Bismarck's attitude toward, 100, 224, 225; political support of, 207

Freisinnige Vereinigung, 225 Freisinnige Volkspartei, 225 French, in population of Germany, 4

Fried, A. H., cited, $89 n$

Gefängnis, 191

Gebeime Fustizrat, $193 n$ 
Gemeine Deutsche Recht, 183

Genossenschaftsämter, 204

Gericbtsdiener, 198

Gericbtssekretäre, 198

Gerichtsverfassungsgesetz, I9I

Gericbtsvollzicher, 198

German Civil Code, history of, 183-187; scope of, 187-188

German Colonial Club, 26I

German Colonial Society, 26I German Colonies, area of,

3 ; increased expenditures on, 135; naval protection needed for, 165, 166; need for, 26I, 262; acquisition of, 263-266; early attitude of England toward, 263; colonial policy, 267, 268; administration of, 268 , 269; territory of, 269; subjects in, 270; government of, $270-274$

German Confederation, of 1815, see Deutsche Bund

German Customs Union, see Deutscbe Zolloerein

German East-Africa, boundary settlement with England, 24I; concessions to England in, 245; occupation of, by Germany, 264, 265; administration of, $271 n, 272$; military organization of, 273; finances of, 273,274

German East-African Society, 264

[326]
German Empire, territory and climate of, 1, 2; neighbors of, 2; effect of location on, 2, 3, II, 12, 158, I59; area of, 3 ; colonial possessions of, 3 ; political divisions of, 3,4 ; population of, 4; religious denominations in, 4, 5; citizenship in, 5-9; institutions of, influenced by racial character, 9-12; causes leading up to formation of, 13-20; adoption of Constitution of, 22, 23; birth of, 22, 23; development of Constitution of, 24-29; increased importance of the Bundesrat, 28, of the Reicbstag, 28, 29, of the Kaiser, 29, 30; administrative centralization of, 30 ; courts of, 30,31 ; administration of legislation of, $3 \mathrm{I}$; military centralization of, 31 , 32; structure of, 33; nature of, 3338 ; relation of, to the states, 40-42; special privileges of states, 42-44; legislative powers of Reicbstag and Bundesrat, 45, 46; universal suffrage in, 4648; constituencies in the Reichstag, 48-50; qualifications of voters in, 50; elections to Reichstag, 50- 


\section{INDEX}

53; conduct of business of Reicbstag, 54-56; personnel of Reichstag, 59-62; composition of Bundesrat, 64 ; organization of Bundesrat, 65-67; functions of Bundesrat, 68; praesidium of, conferred on Prussia, 74; functions and powers of Kaiser, 75-78; William I, 79-83; Frederick III, 8387; William II, 87-96; chancellorship of Bismarck, 98-102; of Caprivi, 102, 103; of Hohenlohe, 103, 104; of Bülow, 104-106; of von Bethmann-Hollweg, 106; vice-chancellorship, 107; leadership of Prussia in, 108; law-making process of, III-II6; internal administration of, I I 7-133; pensions, II9; weights and measures, II9, I20; currency and banking, 120122; protection of patents, 122, 123; supervision of trade and industry, 123127; state insurance, 127132; regulation of medical practice, 132; medical and veterinary police, I33, I34; finances of, 134-148; increased expenditures of, 134, 135; sources of income of, 135-140; Imperial property of, 140; debts of, 140-
I42; unsatisfactory condition of finances, 142, 143; increased army taxes, I43, I44; workings of the budget, I44-I46; control over finances of, 146-147; organization of army of, 149-153; military service in, 153-156; need for strong army, 157-I59; organization of navy of, 160-162; need for adequate navy, I62-I66; railroads of, 167-170; canals of, 171-173; posts, telegraph and telephone service of, 173-175; Civil Code of, 183-188; criminal law of, I88-I9I; organization of courts of, I9I-194; judicial officers of, I96-198; administrative law, 198-202; administrative courts, I98204; political parties in, 205-214; party history in Reichstag, 214-234; foreign policy of, 235-258; alliance of 1879 with Austria, 238; formation of Triple Alliance, 239; alliance with Austria and Russia, 239; diplomatic domination of Europe, 239, 240; alliance with Russia dissolved, 240; friendship with England, 24I; tariff war with Rus[327] 


\section{INDEX}

sia, 242; domination of Europe overthrown by Dual Alliance, 242; gradual return of worldpolicy, 244; policy of, in Far East, 244; naval increase, 244; increasing hostility toward England, 244246; attempts of England to isolate, 246-250; Morocco affair, 247-249, 25 I254; Russia forced to give way to Austria in Balkans by, 250; Bagdad Railway, 251, 252; friendship for Turkey, 251, 252; harmonious action with England in Balkan settlement, 254; strained relations in Europe, 255, 256; the Great War, 256; need for colonies, 26r-262; acquisition of colonial dependencies, 263-266; colonial policy, 267, 268; administration of colonies, 268, 269; territory of colonies, 269; government of colonies, 270-274

German Kaiser, title of, given to King of Prussia, 74, 75 German people, racial character of, 9-II; military virtues of, $\mathrm{I} 1, \mathrm{r} 2$

German Protectorates, citizenship in, 5, 270; governmental authority of Kaiser [328] over, 77, 270; separate Fiskus of, 140; separate budgets of, 145; government of, 270. See also German Colonies

German South-West Africa, revolts in, 135, 230; occupation of, 263, 264; administration of, 27 I $n, 272$; military organization of, 273; finances of, 273

German Union, 5

Gescbäftsordnung, cited, II2 $n$ Gesetz, see Law

Gesundbeitsamt, 132, 135

Gewerbe-Ordnung, 123-127, 191

Gewerbegericbte, 127

Gierke, Prof., cited, I86; 187 n Gladstone, 263, 265

G. O., see Gewerbe-Ordnung

Gold standard, 120

Goodnow, F. J., $202 n$

Gortchakoff, 236, 24I

Gotha, Congress of, 222

Government Printing office, income from, 140

Great Britain, cities of, compared with Germany, $4 n$; William II arouses hostility of, 92-94, 244; Bismarck reconciles Russia with, 99; opposition of, to growth of German navy, I62, $16_{3}$; railroad development of, compared with Germany, I69; objection of, to Peace 


\section{INDEX}

of Stefano, 237; Russia joins Germany and Austria against, 239; friendship of, secured by Bismarck, 240; cedes Heligoland to Germany, 24I; increasing hostility to Germany, 244246; rapprocbement between $F$ rance and, 246; attempts of, to isolate Germany, 246-250; Morocco crisis, 247-249, 251-254; partition of Persia with Russia, 251, 252; harmonious action with Germany in Balkan settlement, 254; the Great War, 256; early indifference of, to German colonization, 263, 265

Greece, 255

Grotewald, Chr., cited, $206 n$ Guam, 161 $n$

Guardianship, 195, 196

Guelphs, 214, 234

Guilds, 124-126

Hänel, Albert, cited, 34, $109 n$

Hamburg, special privileges of, 42 ; reserved privileges of, 43,44 ; representation of, in Reicbstag, 48, in Bundesrat, 64; Imperial naval observatory at, 16r; docks at, 162

Hanover, 16, 64

Hansabund, formation of, 206
Hanse cities, 17, 44

Health Office, 132, 135

Helfferich, K., cited, $169 n$

Heligoland, made German territory, 27; acquired through Caprivi, I03, 24I; inhabitants of, exempt from military service, 153; naval center at, 161

Herzegovina, 236. See also Bosnia-Herzegovina

Hesse, area of, 3 ; joins North German Federation, 22; representation of, in Reicbstag, 48, in Bundesrat, 64

Hesse, Electoral, votes of, in Bundesrat given to Prussia, 64

Hesse Nassau, Electorate of, annexed by Prussia, 19

Higgins, A. P., cited, $187 n$

Hinzpeter, Dr., tutor of William II, 88, $95 n$

Hödel, attempt of, to assassinate William I, 85

Hohenlohe - Langenburg, Prince von, 26I $n$

Hohenlohe - Schillingsfürst, Prince zu, quoted, 92; character and administration of, as Chancellor, 103, 104, 230; return of, to $\mathrm{Bis}$ marck's diplomacy, 244; resignation of, from Colonial Department, 267

Hohenzollern, House of, 11, $80,83,156$ 


\section{INDEX}

Holland, 2

Holstein; 17, 19, 64

Holy Roman Empire, end of, I3; Alsace-Lorraine part of, 176

House of Commons, English, personnel of, 62

"Imperial Gazette," II5, 140

Imperial Law, see Reicbsgesetz

Imperial officers, II7, I I8

Imperial Veterans' Fund, I40, 147

Imperialism, 212

Imports, increase of, 164

Industrial interests, political representation of, 205-207

Industry, regulation of, by G. O., $125-127$

Initiative, advocated by Social-Democratic Party, 213 Innungen, see Guilds

Insurance, state, 127-132, I35 Insurance Office, Imperial, 30 Intendanturen, 149

Italy, commercial treaty concluded by Caprivi with, 103, 137; alienation of, from France over conquest of Tunis, 238, 239; joins Triple Alliance, 239; sides against Germany in Morocco crisis, 249; acquisition of Tripoli by, 249, 254, 255; the Great War, 256 [330]
JAmeson RAID, 92, 93, 244 Japan, William II arouses hostility of, 93; driven by Germany to British alliance, 244; the Great War, 256

Jesuits, expulsion from Empire, 2 r 8

Jews, proportion of, in Reichstag, 62; opposition to, 208, 210

Judges, 50, I96, I97 Judicial powers, of Bundesrat, 70

Judicial system, the Civil Code, I83-I88; criminal law, I88-I9I; organization of courts, I9I-I94; Judicial Officers, 196-I98; administrative law, 198-202; administrative courts, 202204; in the colonies, 272 , 273

Jütland, peninsula of, $\mathbf{1 7 2}$ Fus sanguinis, in determining German citizenship, 5

KAISER, the, proclamation of William I, the first, 22; increased power of, 29; authority of, in colonial, protectorates, $30,77,270$, $27 \mathbf{1}$; position of, in Empire, 37,38 ; constitutional right of, to open and adjourn Bundesrat, 65, 76; Bundesrat committees on Army 


\section{INDEX}

and Marine Affairs appointed by, 66; title of, conferred on King of Prussia, 74, 75; governmental functions of, 76, 77; military power of, 77; governmental authority of, over Alsace-Lorraine, 77; pardoning power of, 77; personal privileges of, 78 ; William I, 79-83; Frederick III, 83-87; William II, 87-96; Bismarck's maintenance of position of, 100, IOI; promulgation of law by, II5; Imperial officers appointed by, II8; military powers of, I50, I 5 I; commander-in-chief of navy, 160; control over postal service, I73; control of foreign affairs by, $76,256-258$

Kaiser Wilhelm Canal, 17r, 172

Kamerun, German occupation of, 253; revolt in, 264; administration of, 271 , 272; military organization of, 273; finances of, 274

Kammergericbt, 193

Kanitz, Count, 62

Keltie, J. S., quoted, 263 , 264

Kiao-chau, administration of, by navy, 16r, 273; occu- pation of, by Germany, 266

Kiel, Imperial naval docks at, 16r, 162

Kiel Canal, I7 r, 172

King of Prussia, 19; becomes Kaiser, 22; title of Kaiser conferred upon, 74, 75; distinction between powers of Kaiser and of, 79

Königgrätz, battle of, 84

Kongo, French, 253

Kongo Conference, 240

Koroci, Prince von, see Hohenlohe-Schillingsfürst

Kruger, Pres. Paul, telegram from William II to, 92, 93, 244

"Kubbandel," 230

Kulturkampf, 217-219

Kuratorium, of Reicbsbank, 122

LABAND, P., cited, $69 n$, $70 n n$ Landed proprietors, political affiliation of, 206

Landgericbie, 192, 193, 197

Landrecbt, in Baden, 183

Landricbter, 192

Land titles, registration of, 195, 196

Lassalle, 46, 47, 222

Lauenburg, united to Prussia, 27; representation of, in Reichstag, 48; in Bundesrat, 64

Law, process of making, in [33I ] 


\section{INDEX}

Germany, I 10-1 16; distinction between Ordinance and, 110

Left, the, in the Reicbstag, 39, 49, 53, 60, 71; attitude of, toward Alsace-Lorraine, 181. See also Liberal, and Social-Democratic Parties

Legislative power, of the Reicbstag and Bundesrat, 45

Leo XIII, Pope, 219

Lèse-majesté, 9, 78, 189

Liao-tung peninsula, 244

Liberal National Movement, comes to end, i6

Liberal Party, wishes of, 39, 47; representation of, in Reichstag, 49, 54, 62, 214; seating of, in Reicbstag, 53; supported by Frederick III, 84; support of Bülow of, 106; composition and principles of, 206, 207, 211 213; in first Prussian Chamber of Deputies, 215; opposition of, to protective tariff, 225; split of, 225; party movement of, in Reichstag, 234

Liberal Union, 225

Liberale Vereinigung, 225

Limitation, Statute of, 190

Lippe, 48, 64

Lorraine, see Alsace-Lorraine Louis II, of Bavaria, 74, 75 Louis XIV, 176

[332]
Louisa, Princess of Mecklenburg-Strelitz, 79

Lowell, A. Lawrence, cited on administrative law, $201 n$

Lübeck, representation of, in Reichstag, 48 , in Bundesrat, 64; naval center at, 16I Lüderitz, 263

MahleR, K., cited, $205 n$ Maitland, Prof., quoted, 187 Manteuffel, ministry of, 84 Marianne Islands, 265 Marshall Islands, 265 Marx, Karl, 46, 222 Matrikularbeiträge, 136-139 Mecklenburg, 17, 71 Mecklenburg-Schwerin, 48, 64 Mecklenburg-Strelitz, 48, 64 Medical police, 132, I33 Memorandum of Prussia, I9 Middle class, political affiliation of, 206, 207

Militärbeamte, 49

Military Fiskus, see Fiskus

Military Law, 32

Military service, period of, extended, 26; term of, reduced, 26; compulsory and universal, 153; active, 153; Landwebr, 153, 154; Landsturm, I54; volunteers, 154 Miquel, Representative, 33 Mobilization, 150, 151

Moltke, 82, 177, 236

Montenegro, 255

Monts, Count, I60 


\section{INDEX}

Morocco, 246, 247

Münster and Osnabrück, Peace of, 13

Nachtigall, 264

Napoleon, 13, 79, 151

Napoleon III, 46, 201

Nassau, 64

National Liberal Party, representation of, in Reichstag, 53, 54, 62; Bismarck's breach with, 100, 219-221; attitude of, toward AlsaceLorraine, I82; composition and principles of, 207 , 212; history of, 216-234

Nationalverein, 216

Naturalization, 6, 7

Navy, Kaiser commander-inchief of, 77, 160; supremacy of Prussia regarding, I14; increased expenses of, 135; organization of, $160-$ 162; need for adequate, 162-166; importance of Kiel Canal to, I72; increase in, 244, 245

New Guinea, German occupation of, 265; administration of, $271 n, 273$; finances of, 273, 274

Nobility, political affiliation of, 206

Normal-Eicbungskommission, 119

North German Federation, formation of, 19-22; 34
November Treaties, 22, 74

Oberelsass, i8 i

Oberlandesgerichte, 193, 194, 198

Obersecamt, 31, 203

Oberstaatsanwalt, 197

Oberstes Landesgericht, 193

Officers, of army, 154, 155

Old-Catholics, 218

Old-Liberal Party, 225

Oldenburg, representation of, in Reicbstag, 48, in Bundesrat, 64

Olmütz, Treaty of, I6, 8I Order of Jesus, see Jesuits Ordinance, distinction between Law and, 110

Organisationsprivilegien, 42

Palaos Islands, 265

Pan-Germanism, 245, 246, $255 n$

Pan-Serbian movement, 250 Pan-Slavism, 236, 241, 255

Paper currency, 12I

Pardoning power, 77

Parker, E. M., cited, $202 n$ Parties, composition and principles of, 205-214; history of, in Reicbstag, 214234

Partnerships, 195

Patent Office, 30, 135, 204

Patentgesetz, $122 n$

Patents, 122, 123, 195 n

Paupers, 7, 8, 43, 50 


\section{INDEX}

Penal Code, cited, $78 n n$

Pensions, I19, 13 I

Persia, 25I, 252

Peters, Dr., 264

Pbysikaliscb - TecbnischeReicbsanstalt, 120

Pius X, Pope, 219

Plenum, 14, 16, 64

Poles, in population of Germany, 4, 5; in Reichstag, 60,144,206, 214, 229, 234 Police, medical and veterinary, 132,133

Pope, temporal power of, opposition to, 104, 217-219

Port Arthur, 244

Poschinger, $M$. von, cited, $83 n, 84 n, 87 n$; quoted, 85 Posts, administered by Empire, 4I; reserved privileges of Bavaria and Würtemberg regarding, 43; administration of, conducted by Kaiser, 76, 77; relation of, to Fiskus, 140; organization and development of, 173175

Potsdam, Convention of, 252 Präsidialanträge, 29, I I I Praesidium, of the North German Federation, 37, 74, 75

Prague, Treaty of, I8, 21

Press Law, I9I

Privileges, special, 42, 43; reserved, 42-44

Professions, regulation of, 125 [ 334]
Progressive People's Party, 225

Protective tariff, 136, 137, I4I, 207, 224, 225, 232

Protestants, proportion of, in Germany, 4, in colonies, 274; in Reichstag, 62; opposition of, to Clerical Party, 230, 231, 233

Prussia, area of, 3 ; conservative and aristocratic, 3 ; population of, 4; Regicrungspräsident in, 6; character of people of, II; destruction of Rbeinbund by, 14; rivalry with Austria, 15; creates Dreikönigsbund, 16; forced to recognize Bundestag, I7; forms Deutscbe Zollverein, 17; Bismarck's policy as ambassador of, I8; war with Austria, 18; forms North German Federation, I9-2I; mákes treaty with southern states, 2I; power of, to defeat constitutional amendments, 24, 25, II4, 1 15; Lauenburg united to, 27; administration of Waldeck ceded to, 27; Heligoland united to, 27; power of, in Bundesrat, 28; military hegemony of, $3 \mathrm{I}$; contingent of, in German army, 31; hereditary right of, to Crown of Empire, 42; 


\section{INDEX}

representation of, in Reichstag, 48, in Bundesrat, 6466; praesidium of Empire conferred on, 74; William I of, 79-83; Frederick III of, 83-87; William II of, 87-96; union of Bavaria with, advocated by Hohenlohe, I04; consequence of leadership of, 108, 109; supremacy of, in legislation, I14-1 16; Imperial military affairs administered by, 149, 150; development of army corps by, 151, 152; army reform by, I53; J. E. Barker quoted on, 156, 157; different civil codes in force in, 183; Kammergericht in, 193; tendencies of Conservative party in, 208

Prussian Rhine Province, 4

Public instruction, $4 \mathbf{I}$

Public meetings, 41

Public prosecutors, 190, I97, 198

Pufendorf, S. von, cited, 36

Pure Food Law, I9r

Puttkammer, von, 86

2uaestors, for supervising finances of Reichstag, 54

Radical Liberal Party, principles of, 212, 213

Radical Party, wishes of, 39
Railroads, regulation of, 43 ; relation of, to Fiskus, I40; of Alsace-Lorraine, I40, 168; Imperial ownership of, planned by Bismarck, I41, 142; constitutional basis for government ownership of, 167, 168; development of, 169; privately owned, I70

Ratibor, Prince von, see Hohenlohe-Schillingsfürst

Ratzel, quoted, 2, 3

Rayonkommission, $3 \mathrm{I}$

Recbnungshof, 146, 147

Recbt der Scbuldverbältnisse, 188

Rechtsanwalt, 198

Referendare, 196

Referendum, 213

Regierungspräsident, 6

Reichsamt für das Heimatwesen, 202, 203

Reicbs- und Staatsangebörigkeitsgesetz, $5 n$

Reicbsanleiben, I4I

Reichsanwalt, 198

Reicbsbank, 121, 122, 140, 242

Reicbsbeamtengesetz, 32, $117 n$

Reicbseisenbabnamt, I68

Reicbsfiskus, see Fiskus

Reichsgericbt, 31, I19, I93, 194, 196-198, 258; inability of, to pass upon constitutionality of law, 1 $16 n$; supreme court of Empire, 191, 192 


\section{INDEX}

Reichsgesetz, $8 n, 27 n$ Reichsgesetzblatt, see "Imperial Gazette"

Reichskanzlei, 107

Reichskassenscheine, 12I, I4I, I47

Reichskolonialamt, 268

Reichsmarineamt, 160

Reichspartei, 217

Reichspostamt, I75

Reichsrayonkommission, 203

Reicbsscbatzamt, 147

Reichsscbuldbuch, 147

Reicbsscbuldenkommission,

147

Reichsschuldenverwaltung, 147 Reichstag, Constitution of the North German Federation adopted by, 20; right of, to propose constitutional amendments, 25 ; remuneration of members of, 26; increased importance of, 28; legislative powers of, 45; treaties must be passed by, 45 ; control of finances by, 46; elections to, 46$48,50-53$; constituencies in, 48-50; organization of, 53; presiding officers of, 53,54 ; conduct of business in, 54-56; term of office of members of, 56 , 57; privileges of members of, 57 ; salaries of members of, 58, 59; personnel of, 59-62; character of, com[336] pared with Bundesrat, 72, 73; opposition of, to Bismarck, 96; law-making process, I IO-I I6; retention of Matrikularbeiträge, 138 , 139; control of budget by, 145, 146; control of finances by, 146; parties of, 205-214; party history of, 214-234; opposition of, to first colonizing experiment, 261

Reicbsverfassung, $24 n, 25 n$, 3 I, 43, $46 n, 65 n, 68 n, 69 n$, $70 n, 71 n, 72 n, 76 n n$, $77 n n, 78,97 n n, 114 n n$, $115 n, 138,139,144,146$, I 5 I $n, 160 n, 256,258$

Reichsversicherungsamt, I29, I30, 203, 204

Religion, regulation of, $4 \mathrm{I}$

Reservatrecbte, 42-44

Reuss (both lines), representation of, in Reicbstag, 48, in Bundesrat, 64

Revisionisten, 2 I3

R. G., see Reicbsgesetz

Rbeinbund, 13

Rbeinbundacte, 13

Rhine Province, 4

Right, the, in the Reicbstag, 39, 53, 60, 144. See also Conservative Party

Roberts, Lord, 93

Robinson, J. H., cited, $70 n$ Roman Law, 183

Roon, 82, $108 n$ 


\section{INDEX}

Roumania, I03, 137

Russia, 2; area of, compared with German Empire, 3, 13; William II arouses hostility of, 93; Bismarck reconciles England with, 99; commercial treaty concluded by Caprivi with, 103, 137; Bismarck's cultivation of, 235; treaty between Austria and, 236; war with Turkey, 236, 237; ingratitude of, toward Bismarck, 237; alliance with Germany and Austria, 239; alliance with Germany dissolved, 240; Dual Alliance formed with France, 24I243; tariff war with Germany, 242; opposition of, to Japan, 244; obliged by Germany to give way to Austria in Balkans, 250; partition of Persia with England, 251, 252; promotion of Pan-Slavism by 256; designs of, on Constantinople, 256; the Great War, 256

R. V., see Reicbsoerfassung

Sachenrecbt, 188

St. Paul's Parliament, 16, 19, 59

Samoa, treaties with England regarding, 245; first attempt of Germany to col- onize, 26I; partition of, with Germany, 265, 266 San Stefano, Peace of, 237 Savigny, 184

Saxe-Altenburg, representation of, in Reicbstag, 48, in Bundesrat, 64

Saxe-Koburg-Gotha, representation of, in Reichstag, 48, in Bundesrat, 64

Saxe-Meiningen, representation of, in Reicbstag, 48, in Bundesrat, 64

Saxony, area of, 3 ; population of, 4; included in Dreikönigsbund, 16; contingent of, in German army, 31, 150, I5I; special privileges of, 43, I21, $130 \mathrm{n}, \mathrm{I} 5 \mathrm{I}$; representation in Bundesrat, 64, 66; Civil Code in, 183

Scbatzanweisungen, I4I Schaumburg-Lippe, representation of, in Reicbstag, 48, in Bundesrat, 64

Schierbrand, von, cited, 90

Schleswig, 19

Schleswig-Holstein, 183

Scböffen, 192

Schraps, $222 n$

Schuster, E. J., cited, $188 n$ Schutzgebiete $269 n$

Scbutzgebietsgesetz, $270 n$, $271 n, 274$

Schwarzburg-Rudolstadt, representation of, in Reichstag, 48 , in Bundesrat, 64 


\section{INDEX}

Schwarzburg - Sondershausen, representation of, in Reicbstag, 48, in Bundesrat, 64 Scbwurgericbte, 192-194

Secessionists, 225

Secretariats, 30

Seeämter, 203

Septennate, 226, 227, 235

Serajevo, Bosnia, 256

Serbia, commercial treaty with, I37; boundary dispute with Austria, 237; Russia forced by Germany to desert, 250; Balkan League joined by, 255; in the Great War, 256

Seydel, Max, cited, 34-36

Shimonoseki, Peace of, 244

Shipping, increase of, 164

Smith, Adam, I23

Social-Democratic Party, wishes of, 39,49 ; representation of, in Reicbstag, 49; disturbances in Reicbstag caused by, 54; decline in personnel of Reicbstag due to, 6o; support of, by William II, $95 n$; Bismarck's struggle with, 99; opposition of, to increased army taxes, I44; composition and principles of, $205-$ 207, 213, 214; history of, 22I-234

Socialist Congress, International, 214

Socialist Party, representa[ 338 ] tion of, in Reicbstag, 49, 54, 62; seating of, in Reicbstag, 53; Bismarck's opposition to, 221-224. See also Social-Democratic Party

South-German People's Party, 225

South Germany, 3, 4

Spain, 248

Staatenbaus, 67

Staatsanevalt, 197

Staatsgervalt, 36

Stanley, H. M., quoted, 24I Steamship companies, 135

Stephan, 173

Sterbegeld, I3I

Stettin, 161, 162; 170

Sticbroabl, 5 I

Stoch, Lt.-Gen., I60

Stöcker, 208

Strafkammern, 192-194

Strassburg, I68, 176, 179

Süd-Deutscbe Volkspartei, 225 Supreme Court, of the Empire, see Reicbsgericbt

Swinemünde, I6r

Switzerland, 2, 3, 137, $138 n$

TAngier, 247

Tardieu, André, quoted, 239, $242,243,245,246,247$; cited, $242,249 n, 250 n$

Taxes; indirect, 136; inheritance, 136, 137; customs duties, 136 , 137; property increment, 136,144 ; stamp, 137, 144; excises, 


\section{INDEX}

137, 144; income, 138, $143 n$; property, for army increase, 143, 144. See also Customs Duties

Telegraphs, 42, 43, 77, 140, 173-175

Telephones, 173-175

Thibaut, quoted, 184

Thirty Years' War, 175, 176

Three-Class System, 47

Tirpitz, von, 16I

Tivoli program, 208, 209

Togo, 264, 271 $n, 272$

Toqueville, A. de, 35, $201 n$ Trade Laws, see GewerbeOrdnung

Trade-marks, I23, I95 $n$

Trades, regulation of, 124, 125

Treason, 8, 9

Treaties, 45

Treitschke, quoted, 17

Triple Alliance, I03, 239

Tunis, 238, 239

Turkey, war with Russia, 236, 237; sovereignty of, over Morocco supported by Germany, 247-249; German interests in, 25I; friendship of Germany with, 251, 252; Tripoli taken by Italy from, 254, 255; the Great War, 256 Tutuila, 16r $n$

\section{Übertretungen, 190}

Ultramontane policy, 230

United States, area of, com- pared with German Empire, 3 ; cities of, compared with Germany, 4; naturalization in, compared to Germany, 6; German Americans, in, Io; constitution of, compared with German, 24, 45; railroad development of, compared with Germany, 169; immigration from Germany, 261, 262

Universal suffrage, 46-48, 50 Urkunden, 196

Vasili, Comte Paul, cited, $87 n$

Venezuela, 165, 245

Verfassungssonderrecbte, 42

Verordnung, see Ordinance

Versailles, 22, 217

Versailles, Treaty of, 177

Veterinary police, 132, 133

Vice-Chancellorship, 107

Victoria, of England, 84

Vienna, Congress of, 14

Vollmar, von, quoted, 214

Vorparlament, 15

Wablprüfungs-Kommission, 52,53

Waitz, 35

Waldeck, administration of, ceded to Prussia, 27; vote of, instructed by Prussia, 28; representation of, in Reicbstag, 48; vote of, in Bundestat given to Prussia, 64

[339] 


\section{INDEX}

Walfish Bay, 263

War treasure, Imperial, 140

Wards, as voters, 50

Webrsteuer, 143

Wends, 4

Wiener Scblussacte, I4 $n$

Wilhelmshafen, I6I

William I, of Prussia, proclaimed Kaiser, 22, $40 n$, 74,75 ; early life of, 79 ; confession of faith of, 80 , $8 \mathrm{I}$; becomes Regent, and King of Prussia, 81; reorganization of Prussian army by, 8I, 82; discovery of Bismark, Roon and von Moltke by, 82; popularity and personal virtues of, 82 ; results of his reign, 83 ; succeeded by Frederick III, 83; quoted, I29

William II, succeeds Frederick III, 87; early character of, 87,88 ; attends public gymnasium, 88, University of Bonn, 88; becomes reactionary, 88 ; his work for world peace, 88,89 ; interest of, in army and navy, 89-9I; varied interests, 9I; progressive and conservative character of, 9I, 92; impulsiveness,
92-94; telegram sent to Kruger by, 92, 93, 244; popularity of, 94; rupture with Bismarck, 95, 96, 102; Caprivi made Chancellor by, 102; visit of, to Tangier, 247, to Damascus, 252; quoted, 89, 9I, 93, $163,231,247,252$

Wind thorst, 226

Woman's Suffrage, 213

Workingmen, legal status and protection of, by G. O., 126; state insurance for, $127-$ 133; political affiliations of, 205-207

Wrangel, Field Marshal, 84

Würtemberg, area of, 3; joins North German Federation, 22; contingent of, in German army, 31, I50, I 5 ; representation of, in Reicbstag, 48, in Bundesrat, 64, 66; limitations of, on military power, 77; special privileges of, 42, 43, I I 8, I 2 I, I I I, I73, I74

Zabern Affair, 178

Zanzibar, Sultan of, 264 Zollverein, see Deutsche Zollverein 



\section{University of California SOUTHERN REGIONAL LIBRARY FACILITY Return this material to the library from which it was borrowed.}

\section{SRLF QL




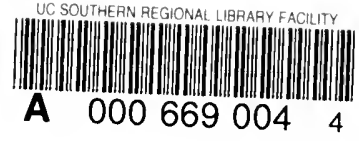




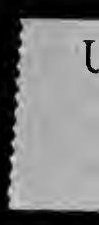

